\title{
DETERMINAÇÃO DA SENSIBILIDADE DE ISOLADOS DE LEISHMANIA A ANTIMONIATO DE MEGLUMINA, ANFOTERICINA B E TAMOXIFENO
}

Dissertação apresentada ao Departamento de Parasitologia da Universidade de São Paulo, para obtenção do Título de Mestre em Ciências pelo programa Biologia da Relação PatógenoHospedeiro.

São Paulo

2009 


\section{DETERMINAÇÃO DA SENSIBILIDADE DE ISOLADOS DE LEISHMANIA A ANTIMONIATO DE MEGLUMINA, ANFOTERICINA B E TAMOXIFENO}

Dissertação apresentada ao Departamento de Parasitologia da Universidade de São Paulo, para obtenção do Título de Mestre em Ciências pelo programa Biologia da Relação PatógenoHospedeiro.

Orientadora: Prof ${ }^{\mathrm{a}}$. Dr ${ }^{\mathrm{a}}$. Silvia Reni Bortolin Uliana

São Paulo

2009 
DADOS DE CATALOGAÇÃO NA PUBLICAÇÃO (CIP)

Serviço de Biblioteca e Informação Biomédica do

Instituto de Ciências Biomédicas da Universidade de São Paulo

(C) reprodução total

Zauli-Nascimento, Rogéria Cristina.

Determinação da sensibilidade de isolados de Leishmania a antimoniato de meglumina, anfotericina B e tamoxifeno / Rogéria Cristina Zauli-Nascimento. -- São Paulo, 2009.

Orientador: Silvia Reni Bortolin Uliana.

Dissertação (Mestrado) - Universidade de São Paulo. Instituto de Ciências Biomédicas. Departamento de Parasitologia. Área de concentração: Biologia da Relação Patógeno-Hospedeiro. Linha de pesquisa: Quimioterapia de leishmanioses.

Versão do título para o inglês: Determination of the sensitivity of Leishmania isolates to meglumine antimoniate, amphotericin B and tamoxifen.

Descritores: 1. Leishmaniose cutânea 2. Quimioterapia 3. Antimônio 4. Anfotericina B 5. Tamoxifeno 6. Sensibilidade Uliana, Silvia Reni Bortolin II. Universidade de São Paulo. Instituto de Ciências Biomédicas. Programa de Pós-Graduação em Parasitologia III. Título. 
Candidato(a):

Título da Dissertação:

Orientador(a):
Rogéria Cristina Zauli-Nascimento.

Determinação da sensibilidade de isolados de Leishmania a antimoniato de meglumina, anfotericina B e tamoxifeno .

Silvia Reni Bortolin Uliana.

A Comissão Julgadora dos trabalhos de Defesa da Dissertação de Mestrado, em sessão pública realizada a ./...................................,
( ) Aprovado(a)
( ) Reprovado(a)

Examinador(a): Assinatura:

Nome:

Instituição:

Examinador(a): Assinatura:

Nome:

Instituição:

Presidente: Assinatura:

Nome:

Instituição: 
Aos meus pais Hilton e Luci, e meus irmãos Caroline e Júnior, pelo incentivo e apoio constantes.

Ao meu marido Tácio, por todo amor, companheirismo, apoio e paciência. 


\section{Agradecimentos}

Agradeço a todos que contribuíram direta ou indiretamente para a realização deste trabalho, e, em especial

À Prof ${ }^{a}$. Dr ${ }^{a}$. Silvia Uliana, pela orientação, pela dedicação e confiança durante o desenvolvimento deste trabalho. Meu agradecimento e respeito, sempre.

Ao Hospital de Doenças Tropicais de Goiânia, principalmente à $\mathrm{Dr}^{\mathrm{a}}$. Ledice Pereira e à Profa. Dra . Mírian Dorta da Universidade Federal de Goiás que nos cederam os isolados avaliados nesse trabalho.

Ao grande amigo e participante constante desse trabalho, Danilo Ciccone, muito obrigada por tudo, pelos ensaios com os camundongos, pelas sugestões, pelas conversas sobre 0 trabalho ou não, pelas várias e várias risadas. Minha admiração, sempre.

À Jenicer, grande amiga e conselheira, pela convivência, sugestões e ajuda em muitos ensaios, pela competência e organização que facilitou muito o trabalho no laboratório, também pelas risadas. Muito obrigada.

À Prof ${ }^{a}$. Dr ${ }^{a}$. Camila I. Oliveira pelo isolado utilizado nos ensaios in vivo.

À Prof ${ }^{\mathrm{a}}$. Dr ${ }^{\mathrm{a}}$. Tania Katzin, por sempre ceder o seu laboratório, pelas análises Microscópicas e sugestões.

Ao Prof. Dr. Alejandro Katzin, por sempre dispor do uso de equipamentos e materiais do seu laboratório.

Aos alunos do Prof. Dr. Michel Rabinovitch pela ajuda com extração de macrófagos de medula.

Ao laboratório da Profa ${ }^{a}$ Dr ${ }^{\mathrm{a}}$. Marta M. G. Teixeira, especialmente à Flávia, Paola, Tarcilla e Ana Cristina pela ajuda com os alinhamentos e árvores filogenéticas. 
À Prof ${ }^{a}$. Dra . Edna Ishikawa da Universidade Federal do Pará pelos ensaios com anticorpos monoclonais.

Ao técnico Alexandre pela ajuda nos ensaios de imunofluorescência, cortes histológicos e microscopia.

Aos colegas do laboratório, Sandra, Alessandro e Cristiana, pelo bom humor e pela ajuda sempre quando necessária.

À Denise, Camila e Fernando, ex-alunos que pouco convivi, mas que me ensinaram de alguma forma.

À Fabiana pelas conversas e ajuda sempre que necessária.

Aos demais professores, alunos e funcionários do Departamento de Parasitologia.

Ao CNPq pelo apoio financeiro. 
"O valor das coisas não está no tempo em que elas duram, mas na intensidade com que acontecem".

Fernando Pessoa 


\section{Abreviaturas}

$\mathrm{kb}$ - kilobase

$\mathrm{kDa}$ - kilodalton

$\mathrm{mM}$ - milimolar

$\mu \mathrm{M}$ - micromolar

$\mathrm{nM}$ - nanomolar

$\mathrm{mL}-$ mililitro

$\mu \mathrm{L}-$ microlitro

$\mathrm{Kg}$ - kilograma

g-grama

mg - miligrama

$\mu \mathrm{g}$ - micrograma

ng - nanograma

$\mathrm{nm}$ - nanometro

UV - ultravioleta

$\mathrm{h}$ - horas

min - minuto

seg - segundos

$v-$ volts

DO - densidade óptica

$\mathrm{UI}$ - unidades internacionais

$\mathrm{v} / \mathrm{v}$ - porcentagem volume volume

DNA - ácido desoxirribonucléico

RFLP - restriction fragment length polymorphism

x $g$ - aceleração da gravidade

${ }^{\circ} \mathrm{C}$ - graus Celsius 


\section{Resumo}

ZAULI-NASCIMENTO, R.C. Determinação da sensibilidade de isolados de Leishmania a antimoniato de meglumina, anfotericina B e tamoxifeno. $138 \mathrm{f}$. Dissertação - Instituto de Ciências Biomédicas, Universidade de São Paulo, São Paulo, 2009.

A terapêutica das leishmanioses se baseia em compostos de administração parenteral com efeitos tóxicos graves e com eficácia clínica variável. A resistência clínica e laboratorial aos antimoniais pentavalentes, drogas de primeira linha, é amplamente detectada no continente asiático. Nesse trabalho avaliamos a sensibilidade a drogas in vitro de alguns isolados obtidos de pacientes brasileiros com leishmaniose cutânea. Os isolados foram tipados como L. (V.) braziliensis, L. (L.) amazonensis e L. (L.) major-like através do polimorfismo de restrição do produto amplificado do gene META2. A tipagem de alguns isolados foi também confirmada por anticorpos monoclonais. Ensaios de sensibilidade in vitro à anfotericina $\mathrm{B}$ e tamoxifeno foram realizados com promastigotas através de um microteste de MTT modificado. Os valores de $\mathrm{Cl}_{50}$ determinados para anfotericina $B$ foram semelhantes para os diversos isolados, variando entre 0,04 $\pm 0,004$ $\mu \mathrm{M}$ e 0,73 $\pm 0,05 \mu \mathrm{M}$, enquanto a razão de resistência variou entre 0,66 0,01 e 2,77 \pm 0,23 . Em relação ao tamoxifeno detectamos sensibilidade homogênea entre os isolados, com valores de $\mathrm{Cl}_{50}$ variando entre $6,0 \pm 0,93 \mu \mathrm{M}$ e 14,8 $\pm 0,99 \mu \mathrm{M}$ com razões de resistência entre $0,68 \pm 0,16$ e 1,31 $\pm 0,56$. A sensibilidade ao antimoniato de meglumina (Glucantime $^{\circledR}$ ) foi avaliada utilizando amastigotas intracelulares obtidos após infecção in vitro de macrófagos derivados de medula óssea de camundongos BALB/c. Os isolados de $L$. (V.) braziliensis apresentaram maior sensibilidade ao Glucantime ${ }^{\circledR}$ do que os isolados de $L$. (L.) amazonensis e $L$. (L.) major-like. Os valores de $\mathrm{Cl}_{50}$ para antimoniato de meglumina variaram entre $18,5 \pm 4,2$ e 146,0 \pm 5,0 e as razões de resistência entre $0,5 \pm 0,23$ e $2,67 \pm 0,35$. Não foi observada correlação entre a resposta clínica dos pacientes ao tratamento e sensibilidade in vitro. Dada a uniformidade detectada na sensibilidade dos isolados ao tamoxifeno in vitro, avaliamos também a eficácia desse fármaco no tratamento de camundongos BALB/c infectados experimentalmente com $L$. (V.) braziliensis. Observamos que a administração intraperitoneal de 20 ou $30 \mathrm{mg} / \mathrm{kg} / \mathrm{dia}$ de tamoxifeno por 15 dias foi eficaz no tratamento da infecção, resultando em redução no tamanho das lesões e carga parasitária em comparação com animais controle. Em paralelo, observamos que um dos isolados analisados (EFSF/06/GO), tipado como L. (V.) 
braziliensis apresentava formas promastigotas atípicas em cultura axênica. Esses parasitas foram parcialmente caracterizados morfológica e funcionalmente, demonstrando-se a ausência de flagelo convencional extracelular na maioria dos promastigotas e presença de um emaranhado arredondado na extremidade anterior, aposta ao bolso flagelar. Observamos também a presença de vesiculações na superfície da membrana plasmática. Esses parasitas foram infectantes in vitro e in vivo, observando-se formas amastigotas com organelas típicas no interior de vacúolos.

Palavras-chave: Leishmaniose cutânea; Quimioterapia; Antimônio; Anfotericina B; Tamoxifeno; Sensibilidade. 


\begin{abstract}
ZAULI-NASCIMENTO, R.C. Determination of the sensitivity of Leishmania isolates to meglumine antimoniate, amphotericin B and tamoxifen. $138 \mathrm{p}$. Master thesis Instituto de Ciências Biomédicas, Universidade de São Paulo, São Paulo, 2009.
\end{abstract}

Therapy of leishmaniasis is based on parenteral administration of compounds with serious toxic effects and with variable clinical efficacy. Laboratorial and clinical resistance to pentavalent antimonials, the first-line drugs, is widely detected in Asia. In this work we evaluated the in vitro sensitivity to drugs of some isolates from Brazilian patients with cutaneous leishmaniasis. Isolates were typed as $L$. (V.) braziliensis, L. (L.) amazonensis and L. (L.) major-like through restriction polymorphism of a META 2 gene amplified product. The typing of some isolates was also confirmed by monoclonal antibodies. Tests for in vitro sensitivity to amphotericin B and tamoxifen were performed with promastigotes through a modified MTT microtest. The $\mathrm{IC}_{50}$ values determined for amphotericin $\mathrm{B}$ were similar for the different isolates, ranging from $0.04 \pm 0.004 \mu \mathrm{M}$ to $0.73 \pm 0.05 \mu \mathrm{M}$, while the resistance ratio ranged from $0.66 \pm 0.01$ to $2.77 \pm 0.23$. Regarding to tamoxifen we detected homogenous sensitivity among the isolates, with $\mathrm{IC}_{50}$ values ranging from $6.0 \pm$ $0.93 \mu \mathrm{M}$ to $14.8 \pm 0.99 \mu \mathrm{M}$ and resistance ratios from $0.68 \pm 0.16$ to $1.31 \pm 0.56$. The sensitivity to meglumine antimoniate (Glucantime ${ }^{\circledR}$ ) was evaluated using intracellular amastigotes obtained after in vitro infection of $B A L B / c$ bone marrow derived macrophages. L. (V.) braziliensis isolates presented higher sensitivity to Glucantime ${ }^{\circledR}$ than $L$. (L.) amazonensis and $L$. (L.) major-like isolates. $I_{50}$ values for meglumine antimoniate ranged between $18.5 \pm 4.2$ and $146.0 \pm 5.0$ and the resistance ratio between $0.5 \pm 0.23$ and $2.67 \pm 0.35$. There was no correlation between clinical response of patients to treatment and in vitro sensitivity. Given the in vitro uniform sensitivity of the isolates to tamoxifen, we also evaluated the effectiveness of this drug in the treatment of BALB/C mice experimentally infected with $L$. $(V$.) braziliensis. We observed that the intraperitoneal administration of 20 or $30 \mathrm{mg} / \mathrm{kg} /$ day tamoxifen for 15 days was efficient in the treatment of infection, resulting in the reduction of lesion sizes and parasite load when compared with control animals. In parallel, we observed that one of the isolates analyzed (EFSF/06/GO), typed as L. (V.) braziliensis, showed atypical promastigote forms in axenic culture. These parasites partially characterized morphologically and functionally. We observed the were absence of conventional extracellular flagellum in most promastigotes 
and the presence of a rounded tangle in the anterior extremity, attached to the flagellar pocket. We also observed the presence of vesicles on the plasma membrane surface. These parasites were infective in vitro and in vivo and amastigotes with typical organelles within vacuoles were observed.

Key words: Cutaneous leishmaniasis; Chemotherapy; Antimony; Amphotericin B;tamoxifen; Sensitivity. 


\section{Sumário}

1 Introdução 17

$\begin{array}{lr}1.1 \text { Considerações gerais } & 17\end{array}$

$\begin{array}{ll}1.2 \text { A leishmaniose } & 18\end{array}$

$\begin{array}{ll}1.3 \text { Tratamento } & 22\end{array}$

1.4 Eficácia de antimoniais no tratamento de leishmaniose: o problema da resistência $\quad 27$

2 Objetivos 31

2.1 Objetivos gerais 32

2.2 Objetivos específicos $\quad 32$

3 Materiais e métodos 33

3.1 Isolados de Leishmania $\quad 34$

3.2 Cultivo de Leishmania $\quad 35$

3.3 Extração de DNA genômico de Leishmania 35

$\begin{array}{ll}3.4 \text { Eletroforese de DNA } & 35\end{array}$

3.5 Reação de polimerização em cadeia (PCR) 36

3.6 Ensaio com anticorpos monoclonais 36

$\begin{array}{ll}3.7 \text { Clonagem } & 36\end{array}$

$\begin{array}{ll}3.8 \text { Ligação } & 37\end{array}$

$\begin{array}{ll}\text { 3.9 Preparação da bactéria competente } & 37\end{array}$

$\begin{array}{ll}3.10 \text { Transformação } & 38\end{array}$

3.11 Purificação de DNA de plasmídeo (Miniprep) 38

$\begin{array}{ll}3.12 & \text { Sequenciamento de DNA } \\ 38\end{array}$

3.13 Análise das sequências de nucleotídeos 39

$\begin{array}{ll}3.14 \text { Drogas } & 39\end{array}$

3.15 Avaliação da atividade de drogas contra promastigotas

39

3.15.1 Análises de turvação $\quad 39$

$\begin{array}{ll}3.15 .2 \text { Teste de MTT clássico } & 39\end{array}$

$\begin{array}{ll}\text { 3.15.3 Microteste de MTT } & \mathbf{4 0}\end{array}$

$\begin{array}{ll}3.16 \text { Cultivo de macrófagos } & 41\end{array}$

3.17 Macrófagos residentes de peritônio de camundongos BALB/c 41

3.18 Obtenção de macrófagos de medula 41 
4.11 Tratamento por via tópica e intraperitonial (IP) com tamoxifeno, anfotericina B e Glucantime ${ }^{\circledR}$

4.12 Quantificação de parasitas por diluição limitante 79

4.13 Caracterização do isolado EFSF/06/GO 81

4.13.1 Microscopia óptica e curva de crescimento 83

4.13.2 Infecção de macrófagos in vitro e de camundongos BALB/c com o isolado EFSF/06/GO

4.13.3 Microscopia eletrônica de transmissão e microscopia eletrônica de varredura

$\begin{array}{ll}\text { 4.13.4 Imunofluorescência } & 90\end{array}$

5 Discussão $\quad 92$

5.1 Isolados e sensibilidade in vitro ao tamoxifeno, anfotericina B e Glucantime ${ }^{\circledR}$

5.2 Eficácia do tamoxifeno no tratamento de infecções por

L. (V.) braziliensis

103

$\begin{array}{ll}\text { 5.3 Morfologia do isolado EFSF/06/GO } & 106\end{array}$

6 Conclusões 109

$\begin{array}{ll}\text { Referências Bibliográficas } & 111\end{array}$

$\begin{array}{lr}\text { Anexo A } & 122\end{array}$

$\begin{array}{lr}\text { Anexo B } & 130\end{array}$

$\begin{array}{ll}\text { Anexo C } & 135\end{array}$ 
Introdução 


\section{Introdução}

\subsection{Considerações gerais}

As leishmanioses são doenças causadas por protozoários do gênero Leishmania, que pertence à família Trypanosomatidae e ordem Kinetoplastida. Esses parasitas infectam uma grande variedade de hospedeiros mamíferos silvestres e domésticos, considerados como reservatórios naturais, e também podem infectar o homem que, em geral, participa do ciclo como hospedeiro acidental. Parasitas do gênero Leishmania apresentam duas formas no seu ciclo de vida: a forma amastigota, que não possui flagelo livre e está presente no interior das células dos hospedeiros vertebrados, e a forma promastigota flagelada que se desenvolve no tubo digestivo dos hospedeiros invertebrados (insetos flebotomíneos) (MOLYNEUX e KILLICK-KENDRICK, 1987).

Nas regiões endêmicas a doença atinge tanto adultos quanto crianças e animais, sendo causada por mais de 20 espécies de Leishmania que são transmitidas por cerca de 30 espécies de insetos flebotomíneos (MURRAY et al., 2005).

O gênero Leishmania subdivide-se em dois subgêneros: Leishmania, onde os promastigotas multiplicam-se e diferenciam-se na porção anterior e média do trato digestivo do inseto vetor e Viannia, que inclui espécies em que os promastigotas se desenvolvem na porção posterior do intestino com migração para a porção anterior (MOLYNEUX e KILLICK-KENDRICK, 1987).

Os hospedeiros invertebrados (insetos transmissores) são dípteros hematófagos da família Psychodidae e subfamília Plebotominae. São difíceis de serem observados porque são muito pequenos, muito pilosos, cor de palha ou castanho-claros e não fazem barulho quando voam. São conhecidos popularmente, dependendo da localização geográfica, como mosquito palha, birigui, tatuquira, cangalha e asa-dura (REY, 2002; BHATTACHARYA et al., 2006).

O parasita é transmitido pela picada do mosquito fêmea do gênero Lutzomyia que abriga as espécies do Novo Mundo (Américas) e do gênero Phlebotomus no Velho Mundo (Europa, Ásia e África) (KISHORE et al., 2006). Esses insetos são mais ativos em lugares sombrios e à noite, e menos ativos durante o período mais quente do dia (BHATTACHARYA et al., 2006).

Durante o ciclo de vida, nos hospedeiros vertebrados as leishmanias habitam os macrófagos teciduais, que fagocitam rapidamente os parasitas quando os encontram 
livres no meio intersticial. No interior dos macrófagos encontram-se as formas amastigotas, que se reproduzem por divisão binária simples. O número de parasitas aumenta até que destruam a célula hospedeira e esta se rompa liberando os protozoários no meio intercelular, onde serão fagocitados por outros macrófagos estendendo sucessivamente a infecção. Nos hospedeiros invertebrados, depois do inseto vetor picar o homem ou animal sugando o sangue infectado, as leishmanias passarão a evoluir no interior do seu tubo digestivo. No intestino médio as formas amastigotas se diferenciam em promastigotas procíclicas que se multiplicam por divisão binária e se diferenciam em promastigotas metacíclicas que são as formas infectivas para o hospedeiro vertebrado. Esse evento é denominado metaciclogênese. Depois de aumentar consideravelmente em número, a grande carga parasitária pode vir a dificultar a ingestão de sangue pelo flebotomíneo quando ele tentar de novo alimentar-se. O inseto pica e suga o sangue muitas vezes, e eventualmente ataca muitas pessoas e/ou animais. Durante a picada o inseto regurgita o material aspirado misturado com os parasitas inoculando as formas infectantes em novos hospedeiros vertebrados. Na pele do vertebrado, ao serem fagocitados pelos macrófagos, se diferenciam em amastigotas (SACKS e KAMHAWI, 2001).

\subsection{A leishmaniose}

A leishmaniose é considerada um dos maiores problemas para a saúde pública do mundo atingindo uma área que compreende 88 países, com cerca de 12 milhões de pessoas infectadas. Aproximadamente 350 milhões de pessoas vivem em áreas de risco e 2 milhões de novos casos são relatados por ano (ORGANIZAÇÃO MUNDIAL DA SAÚDE).

A leishmaniose cutânea é endêmica em mais de 70 países (DESJEUX, 2004). Está amplamente distribuída no continente americano, com registros de casos desde o extremo sul dos Estados Unidos até o norte da Argentina. Já a leishmaniose visceral foi descrita em pelo menos 12 países da América Latina, sendo que $90 \%$ dos casos ocorrem no Brasil, especialmente na região nordeste (MINISTÉRIO DA SAÚDE, 2006).

No Brasil, a leishmaniose está tradicionalmente relacionada com a invasão do homem em florestas onde ocorre a derrubada de árvores para o plantio, construção de estradas, ferrovias, hidrelétricas e implantações de povoados facilitando o contato do homem com os reservatórios e vetores de Leishmania (COSTA, 2005). 
A expansão geográfica na transmissão de leishmaniose no Brasil é clara: na década de 80, a leishmaniose cutânea foi notificada em 19 unidades da federação enquanto em 2003, foram confirmados casos autóctones em todos os estados brasileiros (MINISTÉRIO DA SAÚDE, 2007). Atualmente encontram-se casos de leishmaniose em todas as regiões brasileiras. As regiões Norte e Nordeste se destacam pelo maior número de casos de leishmaniose cutânea, senso que no período de 2000 a 2007 foram notificados nessas regiões casos que somam 85.748 e 69.867 , respectivamente. Surtos epidêmicos vêm sendo relatados em áreas urbanas, incluindo grandes metrópoles como Rio de Janeiro, Belo Horizonte e Recife (SILVA et al., 2001; COSTA, 2008; DANTASTORRES e BRANDAO-FILHO, 2006).

A diversidade genética do parasita em combinação com características do sistema imunológico do hospedeiro contribuem muito para a diversidade dos quadros clínicos na leishmaniose. Assim, a infecção pode se manifestar de quatro formas comuns: leishmaniose cutânea, leishmaniose mucocutânea, leishmaniose cutânea difusa e leishmaniose visceral (SINGH e SIVAKUMAR, 2004; MURRAY et al., 2005).

A leishmaniose cutânea é uma doença benigna que apresenta exclusivamente lesões cutâneas, ulcerosas ou não, porém limitadas à pele, não dando origem a metástases mucosas nem invadindo as vísceras dos pacientes. $\mathrm{Na}$ área do tegumento onde o parasita é inoculado pela picada do inseto ocorrem modificações histológicas que produzem uma reação inflamatória caracterizada por hiperplasia e hipertrofia histiocitária, ou seja, aumento do número e do tamanho dos macrófagos aparecendo como áreas claras da derme e edema. São responsáveis pela doença cutânea nas Américas as espécies Leishmania (V.) braziliensis, L. (L.) amazonensis, L. (V.) panamensis, L. (V.) guyanensis, L. (V.) peruviana, L. (L.) mexicana, L. (L.) pifanoi, L. (L.) venezuelensis e no Velho Mundo L. (L.) tropica, L. (L.) major e L. (L.) aethiopica. No Brasil existem 7 espécies que são responsáveis pela leishmaniose cutânea, sendo 6 do subgênero Viannia e 1 do subgênero Leishmania. As três principais espécies são: L. (V.) braziliensis, L.(V.) guyanensis e L.(L.) amazonensis e, mais recentemente, as espécies L. (V.) lainsoni, L. (V.) naiffi , L. (V.) lindenberg e L. (V.) shawi foram identificadas nas regiões Norte e Nordeste (MURRAY et al., 2005; MINISTÉRIO DA SAÚDE, 2007).

A leishmaniose mucocutânea ou cutâneo-mucosa se complica frequentemente com o aparecimento de lesões ulcerosas destrutivas nas mucosas do nariz, boca e faringe. A propagação dá-se provavelmente por via hematogênica. Nódulos com focos de macrófagos infiltrados podem surgir com raros parasitas e tendência à ulceração, 
localizando-se na porção cartilaginosa do septo nasal. Essas úlceras costumam progredir em extensão e profundidade, com destruição das cartilagens e dos ossos do nariz, da região palatina ou do maciço facial. Progressivamente ocorre a perfuração do septo ou do palato e o processo inflamatório se estende à faringe e à laringe, sendo possível o encontro de metástases cutâneas. Esta forma de leishmaniose recebe também os nomes de espúndia, ferida brava, nariz de tapir e úlcera de Bauru, sendo causada por L. (V.) braziliensis e raramente por $L$. (V.) panamensis (REY, 2002; ALTAMIRANO-ENCISO et al., 2003).

Nas formas disseminadas cutâneas não ulcerosas (leismaniose cutâneo-difusa), o processo tem início com o desenvolvimento de lesão única no ponto de inoculação dos parasitos pelos flebotomíneos. Segue-se uma dispersão metastática que dará origem a lesões múltiplas, não ulcerativas, disseminadas por toda a pele do paciente. Os nódulos são ricos em macrófagos que vão sendo tomados pelos parasitas, mas a reação inflamatória local é muito reduzida ou mesmo ausente. São responsáveis por essa forma de leishmaniose, a $L$. (L.) pifanoi, L. (L.) mexicana e L. (L.) amazonensis nas Américas; ou L. aethiopica, na África (MOLYNEUX e KILLICK-KENDRICK, 1987).

Nas formas viscerais, os parasitas atacam o sistema fagocítico mononuclear (SFM) do baço, fígado, medula óssea e dos tecidos linfóides, determinando a leishmaniose visceral ou calazar. A hipertrofia e a hiperplasia do sistema macrofágico das vísceras é a razão da esplenomegalia (aumento do baço), da hepatomegalia (aumento do fígado), bem como das alterações da medula óssea. Os macrófagos aumentam consideravelmente em número e seu citoplasma torna-se abundante, contenham ou não parasitos em seu interior. São responsáveis pela leishmaniose visceral a $L$. (L.) donovani, L. (L.) infantum e L. (L.) chagasi (SINGH e SIVAKUMAR, 2004; BHATTACHARYA et al., 2006).

No Brasil, a leishmaniose visceral é tipicamente causada por $L$. (L.) chagasi, mas há relatos de casos encontrados no estado da Bahia em que a $L$. (L.) amazonensis era a causa da doença (BARRAL et al., 1991). Em todo o país ocorrem de 3000 a 5000 novos casos por ano de leishmaniose visceral, sendo mais de 4000 casos nos últimos anos. $\mathrm{Na}$ cidade de Natal a doença é predominante em crianças com aproximadamente quatro anos de idade (JERONIMO et al., 2004). A maioria dos casos de leishmaniose visceral no Brasil ocorrem na região nordeste do país. Inicialmente, a doença predominava em ambientes rurais e periurbanos. Nos anos 90, os estados do Pará e Tocantins, Mato Grosso do Sul, Minas Gerais e São Paulo passaram a participar de maneira significativa 
nas estatísticas da leishmaniose visceral no Brasil. Atualmente, está registrada em 19 das 27 Unidades da Federação, com aproximadamente 1.600 municípios apresentando casos autóctones (GONTIJO e MELO, 2004; MINISTÉRIO DA SAÚDE, 2006).

A $L$. (L.) donovani é o agente etiológico da leishmaniose visceral no subcontinente indiano, Ásia e África e a $L$. (L.) infantum ou $L$. (L.) chagasi na região do Mediterrâneo e nas Américas (MURRAY et al., 2005). O maior número de casos de leishmaniose visceral é encontrado na Índia, especialmente em Bihar que é o estado mais populoso e mais pobre do país (BHATTACHARYA et al., 2006; JHA, 2006).

Mais de $90 \%$ dos casos de leishmaniose cutânea atingem o Afeganistão, Arábia Saudita, Argélia, Peru, Brasil, Iran, Iraque, Síria e Sudão (DESJEUX, 2004). Dos casos de leishmaniose visceral, mais de $90 \%$ estão na Índia, Bangladesh, Nepal, Sudão e Brasil. A maioria dos casos mucocutâneos são encontrados na América Latina (SINGH e SIVAKUMAR, 2004; BHATTACHARYA et al., 2006).

Apresentações clínicas atípicas e graves têm sido descritas em associação com imunodepressão, principalmente em pacientes com síndrome da imunodeficiência adquirida. Em 1999, foram diagnosticados mais de 1400 casos de coinfecção HIVLeishmania e $90 \%$ dos casos foram observados na Itália, Espanha e França. Foram encontrados também casos de coinfecção em outras áreas do mundo como na Índia, Brasil, Oeste da África e América do Sul, bem como em pacientes com HIV que viajaram para essas áreas endêmicas (PINTADO e LÓPEZ-VÉLEZ, 2001). Segundo SINGH e SIVAKUMAR (2004), em uma área endêmica de leishmaniose visceral, em cinco casos de pacientes com AIDS a primeira manifestação clínica foi a leishmaniose, que é também uma das doenças oportunistas mais comuns em indivíduos com HIV positivo na Espanha e França.

O diagnóstico da leishmaniose é baseado em exames parasitológicos, imunológicos e moleculares. Os exames parasitológicos (demonstração do parasita, isolamento em cultivo in vitro $\mathrm{e}$ isolamento in vivo (inoculações em animais) são realizados a partir da raspagem ou punção das lesões. Os exames imunológicos incluem a intradermorreação de Montenegro (IDRM) e testes sorológicos. A IDRM é realizada utilizando-se injeção intradérmica de antígeno distribuído pelo Ministério da Saúde. Neste teste, o resultado é avaliado após 48 horas medindo-se o diâmetro da reação no local da injeção que é considerada positiva quando a induração é igual ou maior do que $5 \mathrm{~mm}$. Os testes sorológicos (ELISA e IFI) detectam anticorpos anti-Leishmania presentes no soro dos pacientes. Devido à reação cruzada com outras doenças, esses testes não devem 
ser realizados isoladamente. Os exames moleculares (reação de polimerização em cadeia) são muito utilizados em pesquisas. Apesar de apresentarem alta sensibilidade sendo capazes de detectar e identificar a espécie de Leishmania, são métodos pouco utilizados na rotina diagnóstica por apresentarem custo relativamente alto (MINISTÉRIO DA SAÚDE, 2007).

\subsection{Tratamento}

Em 1912, Gaspar de Oliveira Vianna descreveu que o tártaro emético era eficaz na terapêutica da leishmaniose tegumentar americana. Três anos mais tarde, na Itália, foi relatado o tratamento da leishmaniose visceral com essa droga. Em 1922, a primeira droga à base de antimônio pentavalente (urea estibamina) tendo efeito contra $L$. ( $L$.) donovani foi sintetizada por Brahmchari na Índia (PETER, 1981 apud SINGH e SIVAKUMAR, 2004). Existem vários compostos com atividade contra Leishmania, mas poucos podem ser usados em humanos. A maioria é administrada por via parenteral (SINGH e SIVAKUMAR, 2004).

O tratamento de primeira escolha ainda são os antimoniais pentavalentes $\left(\mathrm{Sb}^{v}\right)$, droga utilizada há mais de 80 anos que pode apresentar efeitos colaterais, alguns dos quais bastante graves como: arritmias cardíacas, nefro, pancreato e hepatotoxicidade. Os antimoniais pentavalentes são rapidamente eliminados pela urina e a administração é feita por via parenteral, intramuscular ou endovenosa. A medicação deve ser administrada por equipe especializada e com o paciente hospitalizado. Os compostos de antimônio usados são o estibogluconato de sódio (SAG) no velho mundo e antimoniato de meglumina (Glucantime ${ }^{\circledR}$ ) nas Américas (REY, 2002; SINGH e SIVAKUMAR, 2004). Para padronização do esquema terapêutico, a Organização Mundial da Saúde (OMS) recomenda que a dose seja calculada em $\mathrm{mg} \mathrm{Sb} / \mathrm{Kg} / \mathrm{dia}$. O Glucantime ${ }^{\circledR}$ é distribuído em ampolas de $5 \mathrm{~mL}$ que contém $1,5 \mathrm{~g}$ de antimoniato de meglumina, correspondendo a 405 $\mathrm{mg}$ de $\mathrm{Sb}^{v}$. Portanto, cada $\mathrm{mL}$ contém $81 \mathrm{mg}$ de $\mathrm{Sb}^{v}$ que é indicado para o tratamento de todas as formas clínicas (Tabela $\mathbf{1}$ ). 
Tabela1: Esquema terapêutico preconizado para as diversas formas clínicas da leishmaniose, segundo a OMS e Ministério da Saúde.

\begin{tabular}{c|c|c}
\hline Forma clínica & Dose & $\begin{array}{c}\text { Tempo de duração } \\
\text { mínimo }\end{array}$ \\
\hline \multirow{2}{*}{ Leishmaniose Cutânea } & $\begin{array}{c}10-20 \mathrm{mg} \mathrm{Sb} / \mathrm{Kg} / \mathrm{dia} \\
\text { Recomenda-se } 15 \mathrm{mg} \\
\mathrm{Sb}^{\mathrm{v}} / \mathrm{Kg} / \mathrm{dia}\end{array}$ \\
\hline Leishmaniose Difusa & $20 \mathrm{mg} \mathrm{Sb} / \mathrm{Kg} / \mathrm{dia}$ & 20 dias \\
\hline Leishmaniose Mucosa & $20 \mathrm{mg} \mathrm{Sb} / \mathrm{Kg} / \mathrm{dia}$ & 30 dias \\
\hline Leishmaniose Visceral & $20 \mathrm{mg} \mathrm{Sb} / \mathrm{Kg} / \mathrm{dia}$ & 20 dias \\
\hline
\end{tabular}

O mecanismo de ação dos antimoniais ainda não é completamente conhecido. $O$ antimônio pentavalente é uma prodroga, sendo necessária a conversão em antimônio trivalente que é a forma ativa contra o parasita (CROFT et al., 2006). O antimônio parece atuar na oxidação de ácidos graxos e glicólise do parasita diminuindo os níveis de adenosina trifosfato intracelular (CROFT e COOMBS, 2003; RATH et al., 2003).

As drogas de segunda escolha para o tratamento de leishmaniose são a pentamidina e anfotericina B. A pentamidina foi primeiramente usada no tratamento da pneumonia causada por Pneumocystis carinii. É uma droga administrada por via intravenosa ou intramuscular. Apresenta maior toxicidade que os antimoniais, por isso é utilizada quando os resultados com antimoniais não são satisfatórios. Os efeitos colaterais apresentados são: dores no local da injeção, náuseas, dores abdominais, dores de cabeça e hipotensão (CROFT e COOMBS, 2003; SINGH e SIVAKUMAR, 2004; MURRAY et al., 2005). Alguns autores descreveram diabetes mellitus em pacientes tratados com essa droga (BHATTACHARYA et al., 2006; JHA, 2006). Segundo MURRAY et al. (2005), na Índia a pentamidina não é um medicamento eficiente que possa substituir os antimoniais. Por outro lado, a pentamidina administrada em sete doses alternadas de $2 \mathrm{mg} / \mathrm{Kg} / \mathrm{dia}$ em pacientes da Colômbia demonstrou boa atividade, com até $96 \%$ de cura (SOTO-MANCIPE et al., 1993).

Não se sabe o exato mecanismo de ação da pentamidina, mas acredita-se que a droga age interferindo na síntese do DNA, alterando o cinetoplasto e fragmentando a membrana mitocondrial (CROFT e COOMBS, 2003; SUNDAR e CHATTERJEE, 2006).

Anfotericina B é um medicamento antifúngico derivado de Streptomyces nodosus também utilizado no tratamento da leishmaniose. É comercializada em frascos contendo 
$50 \mathrm{mg}$ de desoxicolato de sódio em forma de pó liofilizado. A administração dá-se por via endovenosa. Segundo o Ministério da Saúde, recomenda-se no início do tratamento dose de $1 \mathrm{mg} / \mathrm{Kg} /$ dia diariamente ou em dias alternados, sem ultrapassar a dose de $50 \mathrm{mg}$ em cada aplicação. A anfotericina $B$ deve ser administrada até atingir doses totais de 1 a 1,5 g para a forma cutânea e 2,5 a $3 \mathrm{~g}$ para a forma mucosa da doença. A reação adversa mais importante é a nefrotoxicidade e pode levar à diminuição dos teores de potássio e magnésio no organismo (RATH et al., 2003). Quase todos os pacientes apresentam efeitos colaterais como cefaléia, febre, calafrios e náuseas. Alguns têm proteinúria, anemia e leucopenia. É recomendado monitoramento semanal eletrocardiográfico e laboratorial das enzimas hepáticas, função renal (uréia e creatinina) e potássio (MINISTÉRIO DA SAÚDE, 2007).

Anfotericina B interage com a membrana plasmática substituindo as moléculas esteróides, especialmente em membranas com alto conteúdo de ergosterol (BAGINSKI et al., 2005). Com isso há formação de poros, causando aumento de permeabilidade e morte celular (CROFT e COOMBS, 2003; SUNDAR e CHATTERJEE, 2006).

$A$ anfotericina $B$ incorporada em lipossomos é menos tóxica e o tratamento é feito em um curto período de tempo (SOLOMON et al., 2007; JHA, 2006). Apresenta-se comercialmente em ampolas contendo $50 \mathrm{mg}$ de anfotericina B lipossomal liofilizada. É administrada por via endovenosa em doses de $3 \mathrm{mg} / \mathrm{Kg} / \mathrm{dia}$ por 5 dias e no décimo dia doses de $10 \mathrm{mg} / \mathrm{Kg} /$ dia por 2 dias (MURRAY et al., 2005). A droga é carregada para o local onde reside o parasita sendo pouco absorvida pelos rins, que é o órgão mais afetado pela droga (MUSA et al., 2005).

Segundo Berman et al. (1998), doses de $2 \mathrm{mg} / \mathrm{Kg} / \mathrm{dia}$ por 6 dias e mais uma dose no décimo dia de anfotericina $B$ liposomal foram administradas em pacientes com leishmaniose visceral. No Brasil, $62 \%$ desses pacientes foram curados enquanto que no Quênia e na Índia obteve-se $100 \%$ de cura. Pacientes europeus portadores da coinfecção leishmania/HIV tiveram sucesso no tratamento com anfotericina $B$ lipossomal (SUNDAR e CHATTERJEE, 2006). A grande desvantagem da anfotericina B lipossomal é seu alto custo.

Medicamentos atualmente em diferentes fases de testes clínicos para o tratamento de leishmaniose incluem o miltefosine, paromomicina, azitromicina, azóis e alopurinol.

A primeira droga descrita para o tratamento de leishmaniose por via oral foi 0 miltefosine, que é uma droga anti-câncer que teve aprovação na Índia em 2002 para o 
tratamento de leishmaniose visceral (RATH et al., 2003; JHA, 2006). Há relatos que miltefosine é eficaz em casos de resistência aos antimoniais (SUNDAR e CHATTERJEE, 2006).

A variação da sensibilidade de espécies de Leishmania a miltefosine foi demonstrada in vitro por Croft et al. (2006). L. (L.) donovani, L. (L.) aethiopica, L. (L.) tropica, $L$. (L.) mexicana e $L$. (V.) panamensis são mais sensíveis a miltefosine do que $L$. (L.) major. Em isolados clínicos da Colômbia e Guatemala observou-se essa diferença na sensibilidade de leishmaniose cutânea a miltefosine. Em regiões da Colômbia onde $L$. (V.) panamensis é mais comum, a cura com miltefosine foi de $91 \%$. Na Guatemala, em regiões onde $L$. $(V$.$) braziliensis e L$. (L.) mexicana são mais comuns a cura foi de $53 \%$ (SOTO et al., 2004). Pacientes com leishmaniose cutânea na Bolívia foram tratados com miltefosine $(2,5 \mathrm{mg} / \mathrm{Kg} / \mathrm{dia}$ por 28 dias) e somente $88 \%$ tiveram cura da lesão (SOTO et al., 2008).

Existem alguns efeitos colaterais associados a essa droga como vômitos, diarréias, distúrbios gastrointestinais, toxicidade renal e dores de cabeça (BLUM et al., 2004; MURRAY et al., 2005), além de ser um agente teratogênico, contra-indicado para mulheres grávidas ou que estejam amamentando (SUNDAR e CHATTERJEE, 2006). Os mecanismos de ação contra a leishmania ainda não são bem entendidos. Sabe-se que esta droga bloqueia a síntese e altera a composição da membrana celular (CROFT e COOMBS, 2003; SOTO et al., 2004).

A paromomicina (conhecida também como aminosidine) é um antibiótico proveniente de Streptomyces rimosus usado no tratamento de doenças bacterianas. Em 1980, formulações tópicas da paramomicina mostraram ser efetivas no tratamento da leishmaniose cutânea e formulações parenterais no tratamento da leishmaniose visceral (SUNDAR e CHATTERJEE, 2006; CROFT et al., 2006). Recentemente, estudos clínicos com paromomicina foram iniciados na África e na Índia. Segundo Croft e Coombs (2003) o mecanismo de ação da paromomicina envolve danos à mitocôndria. A disfunção respiratória e despolarização da membrana causam a morte do parasita (CROFT et al., 2006). Os efeitos colaterais mais comuns das formulações tópicas são edemas, dores e presença de bolhas (MURRAY et al., 2005). A paromomicina também pode apresentar toxicidade renal e toxicidade para o nervo auditivo (SINGH e SIVAKUMAR, 2004).

Estudos in vitro demonstraram a eficácia da azitromicina contra promastigotas e amastigotas de diferentes espécies de Leishmania (de OLIVEIRA-SILVA et al., 2008). A azitromicina administrada por via oral em doses de $450 \mathrm{mg} / \mathrm{Kg} / \mathrm{dia}$ por 5 dias apresentou 
atividade em hamsters infectados com $L$. (V.) braziliensis e nenhuma atividade em hamsters infectados L. (L.) amazonensis (SINAGRA et al., 2007). Quando esse medicamento foi usado em tratamento clínico de pacientes com leishmaniose cutânea, apenas $85 \%$ dos pacientes responderam ao tratamento (PRATA et al., 2003). No estado de Minas Gerais, três pacientes com leishmaniose mucocutânea receberam dose única diária de $500 \mathrm{mg} / \mathrm{Kg}$ por 10 dias, sendo que após seis meses um dos pacientes apresentou recidiva (SILVA-VERGARA et al., 2004).

Alguns azóis como cetoconazol, itraconazol e fluconazol atuam inibindo a síntese de ergosterol e já foram utilizados na terapêutica da leishmaniose (CROFT et al., 2006). Promastigotas de L. (L.) donovani, L. (V.) braziliensis e $L$. (L.) amazonensis foram mais sensíveis ao cetoconazol do que promastigotas de L. (L.) aethiopica, L. (L.) major, L. (L.) tropica e L. (L.) mexicana in vitro (CROFT et al., 2006). Pacientes na Colômbia tratados com itraconazol (400 mg/dia/28 dias) apresentaram falha terapêutica de até $75 \%$ (SOTOMANCIPE at al., 1993).

Outro medicamento testado no tratamento de leishmaniose cutânea e visceral é o alopurinol. Identificado há aproximadamente 30 anos, apresenta vantagens por ser de baixo custo, fácil administração (via oral) e baixa toxicidade, mas parece não controlar muito bem as infecções (KAMAU et al., 2000; RATH et al., 2003; CROFT e COOMBS, 2003). O tratamento da leishmaniose cutânea colombiana com alopurinol mostrou-se ineficaz (SINGH e SIVAKUMAR, 2004). Já o tratamento contra $L$. (V.) panamensis foi mais eficaz com a combinação de alopurinol e antimonial do que somente com antimonial nas mesmas doses (20 mg/Kg/dia por 15 dias) (BLUM et al., 2004). Fluconazol e alopurinol quando administrados juntos são bem tolerados e bastante ativos contra Leishmania. Os efeitos colaterais mais comuns são febre, náuseas, vômitos e perda de peso (COLAKOGLU et al., 2006).

O alopurinol atua inibindo a síntese de purinas e tem rápido metabolismo e excreção (CROFT e YARDLEY, 2002; CROFT et al., 2006). COLAKOGLU et al. (2006) relataram um caso de paciente com leishmaniose visceral que apresentava insuficiência renal e que foi tratado com sucesso com a associação de alopurinol e fluconazol.

Alguns medicamentos utilizados no tratamento de leishmanioses são agentes antifúngicos, antibacterianos e anticâncer. Muitos estudos têm sido dedicados à pesquisa de novos agentes quimioterápicos eficazes contra esse parasita.

O tamoxifeno é um trifeniletileno, droga antiestrogênica utilizada há mais de 20 anos no tratamento e prevenção do câncer de mama (JORDAN, 2003; JONAT et al. 
2006; VOGEL et al., 2006). O mecanismo de ação se dá pela ligação da droga a receptores de estrógeno bloqueando o crescimento das células no tumor (ALTAN et al., 1999; JONAT et al. 2006). Os efeitos colaterais mais comuns relacionados a essa droga são cefaléia, náuseas e vômitos (INADA et al., 2005). Em períodos mais longos de tratamento pode resultar no desenvolvimento de tumores no útero. Há casos de retinotoxicidade, mas são relativamente raros (ALTAN et al., 1999; INADA et al., 2005; JONAT et al. 2006; GRILLI, 2006).

O tamoxifeno também age independentemente da interação com o receptor de estrógeno inibindo a acidificação de organelas intracelulares, a atividade de proteína quinase $\mathrm{C}$, a secreção de proteases, a atividade de calmodulina e de fosfodiesterase (WISEMAN et al., 1990; CHEN et al., 1999). O tamoxifeno parece também interagir com membranas alterando sua funcionalidade.

A sensibilidade de microrganismos ao tamoxifeno foi avaliada em Candida albicans (BEGGS, 1996) e Coccidioides immitis in vitro (DRUTZ et al., 1981). Em nosso laboratório mostramos que o tamoxifeno é ativo contra promastigotas de $L$. (V.) braziliensis, L. (L.) amazonensis, L. (L.) chagasi, L. (L.) donovani e L. (L.) major, e amastigotas de L. (L.) amazonensis in vitro (MIGUEL et al., 2007). Quando esse trabalho foi iniciado, resultados preliminares obtidos em nosso laboratório indicavam que o tamoxifeno era eficaz no tratamento de infecções por $L$. (L.) amazonensis em modelo experimental. Esses resultados foram confirmados posteriormente por Miguel et al. (2008).

O mecanismo de ação desta droga na Leishmania é ainda completamente desconhecido. O tamoxifeno é capaz de alcalinizar vacúolos de macrófagos infectados com amastigotas de L. (L.) amazonensis, mas isso não foi suficiente para matar o parasita (MIGUEL et al., 2007).

\subsection{Eficácia de antimoniais no tratamento de leishmaniose: o problema da resistência}

A cura da leishmaniose depende de vários fatores como o sistema imune do hospedeiro, a cepa adquirida, a forma clínica da doença e a droga utilizada. Em todas as áreas endêmicas encontram-se casos que não respondem ao tratamento. A resistência de isolados de $L$. (L.) donovani aos antimoniais é observada em larga escala na Índia, especialmente no estado de Bihar. Isolados de diferentes áreas geográficas de Bihar 
avaliados quanto à sensibilidade aos antimoniais revelaram que $37.6 \%$ foram sensíveis e 62.4\% resistentes a essa droga (THAKUR et al., 2004). Depois que os antimoniais se mostraram ineficazes, as drogas de segunda escolha como anfotericina B e miltefosine passaram a ser indicadas no tratamento da leishmaniose obtendo-se 90\% de cura (SUNDAR et al., 2001). Em um estudo recente realizado no Sudão, Sharief et al. (2006) avaliaram a sensibilidade de isolados de $L$. (L.) donovani aos antimoniais e anfotericina $B$. De oito isolados, seis mostraram-se resistentes aos antimoniais e todos responderam ao tratamento com anfotericina $\mathrm{B}$.

Em Israel, 27 pacientes foram diagnosticados apresentando leishmaniose cutânea causada por L. (V.) braziliensis. Esses pacientes foram infectados em uma área endêmica da Bolívia para onde haviam viajado. Foram tratados com antimônio pentavalente $(20 \mathrm{mg} / \mathrm{Kg} /$ dia durante $25 \mathrm{dias}$ ), sendo que $37 \%$ dos pacientes não responderam ao tratamento e $63 \%$ tiveram que interrompê-lo devido a efeitos adversos (SOLOMON et al., 2007). Um grupo de pacientes da Bolívia que apresentavam a forma cutânea da doença foram tratados com Glucantime ${ }^{\circledR}(20 \mathrm{mg} / \mathrm{Kg} /$ dia por 20 dias) obtendo $94 \%$ de cura (SOTO et al., 2008). Na Colômbia os pacientes apresentam resposta terapêutica de até 91\% (SOTO-MANCIPE et al., 1993). No Peru, de 26 isolados de L. (V.) braziliensis 22 apresentaram resistência aos antimoniais. Estes pacientes foram então tratados com anfotericina B (YARDLEY et al., 2006).

No Brasil, a cura da leishmaniose visceral com antimoniais é considerada alta, com relatos de sucesso terapêutico em mais de 95\% dos pacientes. Na cidade de Teresina, capital do estado do Piauí, a avaliação de pacientes tratados com antimoniais mostrou que apenas $5 \%$ dos pacientes não responderam ao tratamento, necessitando da administração de drogas de segunda escolha (SANTOS et al., 2002; WERNECK et al., 2003). Em áreas endêmicas em Pernambuco e Bahia, pacientes com leishmaniose tegumentar causada por $L$. $(V$.) braziliensis foram tratados com antimoniais obtendo sucesso com o tratamento (FOLLADOR et al., 1999; ANDRADE et al., 2005). Em um estudo realizado no Rio de Janeiro, de 159 pacientes com leishmaniose cutânea, 23 (16\%) apresentaram falha terapêutica no tratamento com antimônio pentavalente (OLIVEIRA-NETO et al., 1997). No entanto, esses pacientes foram tratados com um esquema de baixas doses ( $5 \mathrm{mg} / \mathrm{Kg} /$ dia por 30 dias).

Para iniciar um tratamento de leishmaniose é importante saber das manifestações clínicas e também da sensibilidade da droga que depende das espécies de Leishmania (CARVALHO et al., 2006). Encontra-se na literatura vários trabalhos sobre isolados de 
espécies de Leishmania em regiões do Brasil. Apesar de relatos de falha terapêutica de antimoniais em pacientes brasileiros, até o momento apenas um estudo analisou a sensibilidade in vitro de isolados brasileiros de Leishmania às drogas comumente utilizadas na quimioterapia. Neste estudo, Azeredo-Coutinho et al. (2007) demonstraram que os isolados menos sensíveis ao antimônio, observado nos experimentos in vitro, correspondiam aos pacientes que apresentaram falha terapêutica ou recaída.

Devido a isto percebemos que é de grande importância a avaliação in vitro da sensibilidade dos parasitas a várias drogas.

Em todas as regiões do Brasil encontram-se casos de leishmanioses. A região nordeste é a que apresenta o maior número de casos da doença (GONTIJO e MELO, 2004; LAINSON e RANGEL, 2005; DANTAS-TORRES e BRANDAO-FILHO, 2006; TOJAL DA SILVA et al., 2006). No estado da Bahia, há relatos de que L. (V.) braziliensis é o agente etiológico predominante da leishmaniose cutânea (ROMERO et al., 2001). Barral et al. (1991) isolaram amostras de pacientes com diferentes formas clínicas de leishmanioses no estado da Bahia. Desses isolados, 40 foram identificados como $L$. (L.) amazonensis, 39 como L. (V.) braziliensis e 35 como L. (L.) chagasi. Em Goiás, de 1994 a 2003 foram notificados 469 casos de leishmaniose tegumentar distribuídos em 39\% dos municípios. Niquelândia é o município que se destacou com $22 \%$ dos casos do estado. Foi notificada uma incidência de 8,8 casos por 100 mil habitantes e um percentual de $68 \%$ de cura. Quanto à leishmaniose visceral foram confirmados 35 casos em $5 \%$ dos municípios, com alto número de mortes (17\%) e incidência menor que 1 caso a cada 100 mil habitantes (MINISTÉRIO DA SAÚDE, 2005). Não foi encontrado nenhum trabalho que tenha testado drogas de primeira escolha ou de segunda escolha em isolados de Leishmania no estado de Goiás, Bahia, Tocantins e/ou Pará. Uma colaboração estabelecida entre nosso laboratório e a Dra . Miriam Dorta e Dr ${ }^{\mathrm{a}}$. Glória M. C. A. A. Lima (UFGO) nos permitiu obter 15 culturas de Leishmania, todos isolados recentes de pacientes com leishmaniose cutânea provenientes de Goiás, Bahia, Tocantins, Pará e Guiana Francesa.

Dos 15 pacientes com leishmaniose tegumentar americana, 12 apresentavam a forma cutânea localizada, 1 deles apresentava a forma mucocutânea da doença, 1 apresentava a forma cutânea disseminada e 1 a forma cutânea difusa. Estes pacientes foram tratados com diferentes doses de Glucantime ${ }^{\circledR}$ e avaliados em ambulatório na cidade de Goiânia, Goiás. Dois desses pacientes já haviam recebido tratamento prévio com antimonial e não tinham apresentado resposta clínica. Um deles já havia sido tratado 
também com pentamidina e itraconazol. Quatro pacientes não retornaram para o tratamento e não puderam ser seguidos (Tabela 2).

Assim, decidimos avaliar a sensibilidade desses isolados às drogas comumente utilizadas na terapêutica. Considerando a eficácia do tratamento com tamoxifeno observada por nosso grupo em modelo experimental de L. (L.) amazonensis, decidimos também ampliar a avaliação de tamoxifeno como potencial quimioterápico para leishmaniose, avaliando sua eficácia em modelo experimental de $L$. (V.) braziliensis e analisando o padrão de sensibilidade de isolados de campo a esse fármaco.

Tabela 2: Isolados brasileiros obtidos de pacientes com leishmaniose cutânea

\begin{tabular}{|c|c|c|c|c|c|}
\hline $\begin{array}{c}\text { Paciente/ano/ } \\
\text { local }\end{array}$ & $\operatorname{Sexo}^{a}$ & $\begin{array}{l}\text { Idade } \\
\text { (anos) }\end{array}$ & $\begin{array}{c}\text { Tempo de } \\
\text { lesãob }\end{array}$ & $\begin{array}{l}\text { Forma } \\
\text { Clínica }^{c}\end{array}$ & $\begin{array}{c}\text { Tratamento } \\
\text { anterior }^{\mathrm{d}}\end{array}$ \\
\hline $\mathrm{BES} / 06 / \mathrm{GO}^{L b}$ & M & 41 & $8 \mathrm{~m}$ & CL & $\begin{array}{c}\text { Glucantime }^{\circledR} \\
(>18 \mathrm{~g} \mathrm{AM})\end{array}$ \\
\hline $\mathrm{EFSF} / 06 / \mathrm{GO}^{L b}$ & $\mathrm{~F}$ & 44 & $3 \mathrm{~m}$ & $\mathrm{CL}$ & nenhum \\
\hline $\mathrm{GDL} / 06 / \mathrm{GO}^{L b}$ & $\mathrm{~F}$ & 60 & $8 \mathrm{~m}$ & $\mathrm{CL}$ & nenhum \\
\hline $\mathrm{HPV} / 06 / \mathrm{TO}^{L b}$ & M & 46 & $3 \mathrm{~m}$ & $C L$ & nenhum \\
\hline $\mathrm{IMG} / 03 / \mathrm{GO}^{L b}$ & $\mathrm{~F}$ & 43 & $1,5 \mathrm{~m}$ & $\mathrm{CL}$ & nenhum \\
\hline $\mathrm{PPS} / 06 / \mathrm{BA}^{L b}$ & M & 69 & $20 \mathrm{a}$ & MC & nenhum \\
\hline $\mathrm{RPL} / 05 / \mathrm{GF}^{L b}$ & M & 46 & $3 \mathrm{~m}$ & $\mathrm{CL}$ & nenhum \\
\hline $\mathrm{TMB} / 06 / \mathrm{GO}^{L b}$ & $\mathrm{~F}$ & 15 & $3 \mathrm{~m}$ & $C L$ & nenhum \\
\hline $\mathrm{UAF} / 06 / \mathrm{TO}^{L b}$ & M & 29 & $2 \mathrm{~m}$ & $\mathrm{CL}$ & nenhum \\
\hline WSS/05/GO ${ }^{L b}$ & $M$ & 22 & $8 \mathrm{~m}$ & $\mathrm{CL}$ & nenhum \\
\hline $\mathrm{EGS} / 04 / \mathrm{GO}^{\mathrm{La}}$ & M & 57 & $2 \mathrm{~m}$ & $\mathrm{CL}$ & nenhum \\
\hline $\mathrm{JRS} / 01 / \mathrm{GO}^{\mathrm{La}}$ & M & 29 & $4 \mathrm{~m}$ & CS & nenhum \\
\hline $\mathrm{JSC} / 06 / \mathrm{PA}^{\mathrm{La}}$ & M & 57 & $1,5 \mathrm{~m}$ & $\mathrm{CL}$ & nenhum \\
\hline $\mathrm{MAB} / 03 / \mathrm{PA}^{L m}$ & M & 19 & $14 \mathrm{a}$ & $C D$ & $\begin{array}{l}\text { Pentamidina, } \\
\text { Glucantime }{ }^{\circledR} \mathrm{e} \\
\text { Itraconazol }\end{array}$ \\
\hline VBL/01/PA ${ }^{L m}$ & M & 19 & $4 \mathrm{~m}$ & $\mathrm{CL}$ & nenhum \\
\hline
\end{tabular}


Objetivos 


\section{Objetivos}

\subsection{Objetivos gerais}

Avaliar a sensibilidade de isolados de Leishmania obtidos de pacientes brasileiros a antimoniato de meglumina, anfotericina $B$ e tamoxifeno.

\subsection{Objetivos específicos}

- Confirmar a identificação dos isolados de pacientes com leishmaniose cutânea de diferentes regiões brasileiras

- Padronizar um método para avaliar a sensibilidade de promastigotas e amastigotas in vitro

- Utilizando amastigotas intracelulares, avaliar a sensibilidade de isolados de Leishmania ao antimoniato de meglumina

- Utilizando promastigotas, avaliar a sensibilidade dos isolados a anfotericina B e tamoxifeno

- Correlacionar a resposta clínica dos pacientes ao tratamento com a atividade in vitro

- Analisar a atividade de tamoxifeno in vivo em modelo experimental de infecção com L. (V.) braziliensis 
Materiais e Métodos 


\section{Materiais e métodos}

\subsection{Isolados de Leishmania}

Os isolados de Leishmania utilizados neste trabalho foram obtidos de pacientes provenientes dos estados de Goiás $(n=8)$, Bahia $(n=2)$, Pará $(n=3)$, Tocantins $(n=2)$ e da Guiana Francesa $(n=1)$ (Figura 1). O diagnóstico dos pacientes e isolamento dos parasitas foram realizados no Hospital de Doenças Tropicais de Goiânia, Goiás, Brasil. As linhagens referência utilizadas foram $L$. (V.) braziliensis MHOM/BR/1975/M2903 e $L$. (L) amazonenis MHOM/BR/1973/M2269. A linhagem de L. (V.) braziliensis $\mathrm{MHOM} / \mathrm{BR} / 2001 / \mathrm{BA}$ isolada de um paciente do estado da Bahia utilizada nesse trabalho foi cedida pela Drª . Camila Indiani de Oliveira, do Centro de Pesquisas Gonçalo Muniz, Fiocruz, BA.

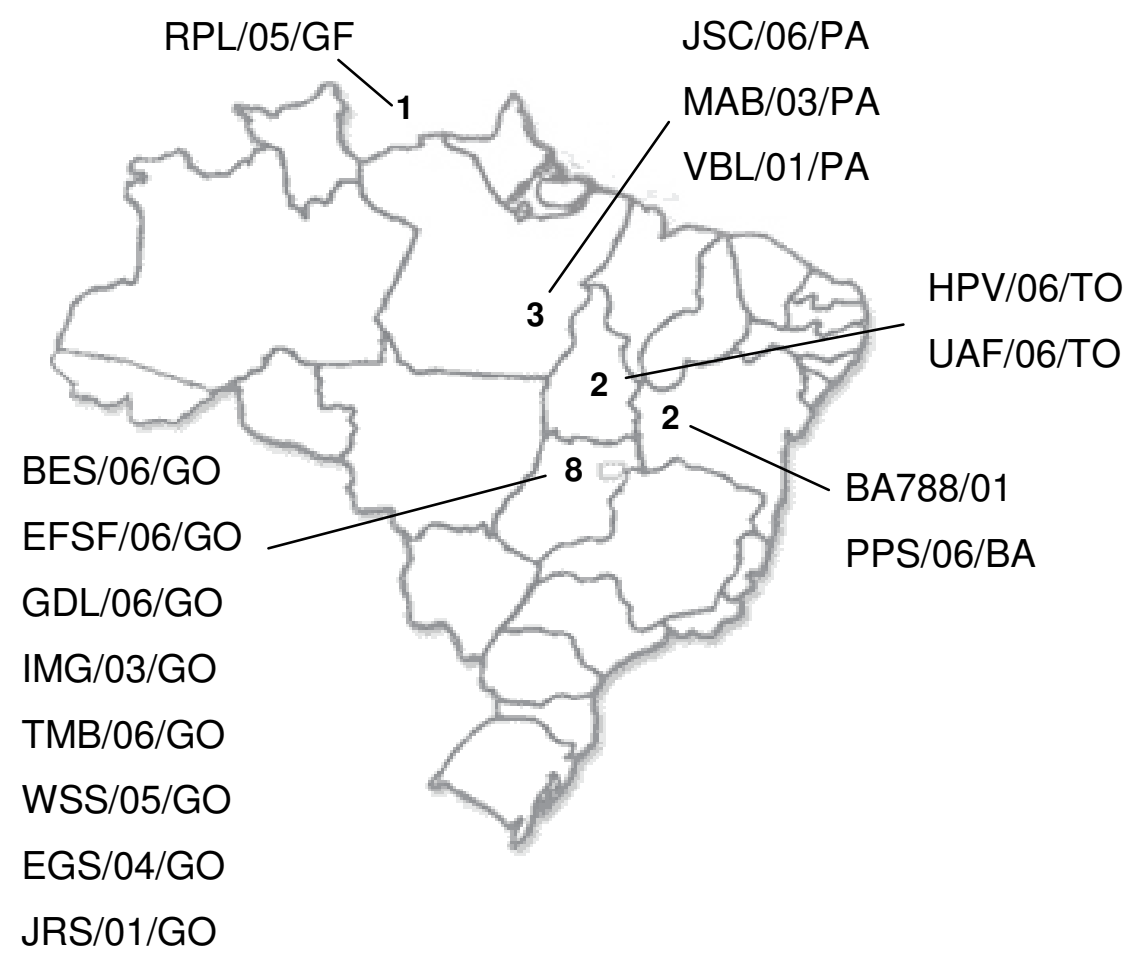

Figura 1: Distribuição geográfica dos isolados de Leishmania obtidos de pacientes brasileiros. 


\subsection{Cultivo de Leishmania}

As formas promastigotas de parasitas do gênero Leishmania foram cultivadas em meio 199 (Gibco-BRL), que foi preparado diluindo-se o pó para meio 199 em água destilada e adicionando-se HEPES $40 \mathrm{mM}, \mathrm{pH} 7,4$, adenina $0,1 \mathrm{mM}$, hemina 0,005\%, suplementado com $10 \%$ de soro fetal bovino (SFB) e $100 \mu \mathrm{g} / \mathrm{mL}$ de penicilina/estreptomicina. Para as espécies de $L$. (V.) braziliensis o meio de cultivo foi acrescido de $2 \%$ de urina humana masculina estéril. O meio foi esterilizado por filtragem e mantido em prova de esterilidade durante $24 \mathrm{~h}$ a $37^{\circ} \mathrm{C}$. As culturas foram mantidas em estufa a $25^{\circ} \mathrm{C}$.

\subsection{Extração de DNA genômico de Leishmania}

Após contagem das células em câmara de Neubauer, $1 \times 10^{8}$ células de fase estacionária foram coletadas por centrifugação a $690 \times g$ por $10 \mathrm{~min}$. O sobrenadante foi descartado e o sedimento ressuspenso em $150 \mu \mathrm{L}$ de TELT (Tris $50 \mathrm{mM} \mathrm{pH} \mathrm{8,0;} \mathrm{EDTA}$ $62,5 \mathrm{mM} \mathrm{pH}$ 9,0; LiCl 2,5 M e TRITON X-100 4\%) que foi incubado a temperatura ambiente por $5 \mathrm{~min}$. Foram adicionados $150 \mu \mathrm{L}$ de fenol/clorofórmio $1: 1$ (vol/vol), agitando-se a mistura lentamente por $5 \mathrm{~min}$. A mesma foi então centrifugada a $13040 \mathrm{xg}$ por 5 min. O sobrenadante foi transferido para um tubo contendo $300 \mu \mathrm{L}$ de etanol, homogeneizado e incubado por 5 min a temperatura ambiente. A mistura foi então centrifugada a 13040 × g por $5 \mathrm{~min}$, descartando-se o sobrenadante. Após evaporação do etanol residual, ressuspendeu-se o sedimento em $50 \mu \mathrm{L}$ de TE (Tris $10 \mathrm{mM} \mathrm{pH} \mathrm{7,0,} \mathrm{EDTA}$ $1 \mathrm{mM} \mathrm{pH} 8,0$ ) e RNase $0,2 \mathrm{mg} / \mathrm{mL}$. Incubou-se em estufa a $37^{\circ} \mathrm{C}$ durante $1 \mathrm{~h}$ e o DNA extraído foi mantido em refrigerador a $4 \stackrel{\circ}{\circ}$ (MEDINA-ACOSTA e CROSS, 1993).

\subsection{Eletroforese de DNA}

Para separar os fragmentos de DNA foi utilizado gel de agarose na concentração de 0,8\% em tampão TAE 1X (Tris-acetato $40 \mathrm{mM} \mathrm{pH} \mathrm{8,0;} \mathrm{EDTA} 1 \mathrm{mM}$ ). Para visualização do DNA, o gel foi corado com brometo de etídio $(0,75 \mu \mathrm{g} / \mathrm{mL})$, observado em transiluminador de UV e fotografado em Eagle Eye (Stratagene). DNA de fago $\lambda$ (Fermentas) digerido com Hin dIII (New England Biolabs) foi utilizado como padrão de peso molecular. 


\subsection{Reação de polimerização em cadeia (PCR)}

Para as reações de PCR foi utilizado o método de Mullis e colaboradores (1986) com a seguinte mistura de reação: 100 ng de DNA genômico, 100 ng de cada "primer", $10 \mathrm{mM}$ de cada dNTP, $5 \mu \mathrm{L}$ de tampão $10 \times$ (Tris $\mathrm{HCl} 750 \mathrm{mM} \mathrm{pH} \mathrm{9,0;} \mathrm{KCl} 500$ mM; $\mathrm{MgCl}_{2} 20 \mathrm{mM}$ e $\left.\left(\mathrm{NH}_{4}\right)_{2} \mathrm{SO}_{4}\right) 200$ mM, $5 \mathrm{UI}$ de Taq DNA polimerase e água (bidestilada e autoclavada) para um volume final de $50 \mu \mathrm{L}$.

Condições de reação: 1 ciclo: 1 min a $94{ }^{\circ} \mathrm{C}$; 30 ciclos: 1 min a $94{ }^{\circ} \mathrm{C}$; 1 min na temperatura de anelamento dos "primers"; 1 min a $72^{\circ} \mathrm{C}$ e 1 ciclo: 7 min a $72^{\circ} \mathrm{C}$.

Os "primers" utilizados foram: LbM2a: 5' ATG TCC ACT GCC GAC AT 3' e LbM2b: 3' CTA AAT AGG CTC AGC GTC GT 5' complementares às extremidades 5' e 3' do gene META 2 de L. (V.) braziliensis (geneDB.org); IR1: 5' GCT GTA GGT GAA CCT GCA GCA GCT GGA TCA TT 3'; IR2: 5' GCG GGT AGT CCT GCC AAA CAC TCA GGT CTG 3' e 5.8R: 5' GGA AGC CAA GTC ATC CAT C 3' (CUPOLILLO et al., 1995). produto amplificado do gene META 2 foi digerido com a enzima Xho I (Biolabs).

\subsection{Ensaio com anticorpos monoclonais}

Os ensaios com anticorpos monoclonais foram realizados pela Prof $^{\mathrm{a}}$. $\mathrm{Dr}^{\mathrm{a}}$. Edna Ishikawa da Universidade Federal do Pará.

Para preparação da lâmina, os promastigotas foram centrifugados a $1000 \times g$ por 10 min e lavados uma vez em PBS pH 7,2 $\left(\mathrm{NaH}_{2} \mathrm{PO}_{4} 2,5 \mathrm{mM}, \mathrm{Na}_{2} \mathrm{HPO}_{4} 7,4 \mathrm{mM}\right.$ e $\mathrm{NaCl}$ $137 \mathrm{mM}$ ). Foram adicionados $10 \mu \mathrm{L}$ da solução contendo $1 \times 10^{6}$ parasitas $/ \mathrm{mL}$ em cada poço da lâmina e após 90 seg foi removido todo o excesso deixando-se secar a lâmina a temperatura ambiente. A fixação foi feita com acetona por $15 \mathrm{~min}$.

Os anticorpos monoclonais utilizados foram: B2, B5, B11, B12, B18, B19, M2, T3, CO2, L1, WIC, W1, W2, N2, N3 e WA2 (MCMAHON-PRATT et al., 1982; HANHAM et al., 1991; SHAW et al., 2007).

\subsection{Clonagem}

Foi utilizado como vetor o plasmídeo TOPO do kit para sequenciamento "TOPO TA Cloning® kit for sequencing" (Invitrogen ${ }^{\mathrm{TM}}$ ). 
Como inserto foi utilizado o produto da PCR das regiões ITS1, 5.8S e ITS2 (espaçadores transcritos internos) localizadas entre os genes 18S e 24S $\alpha$ do RNA ribossômico (Figura 2).

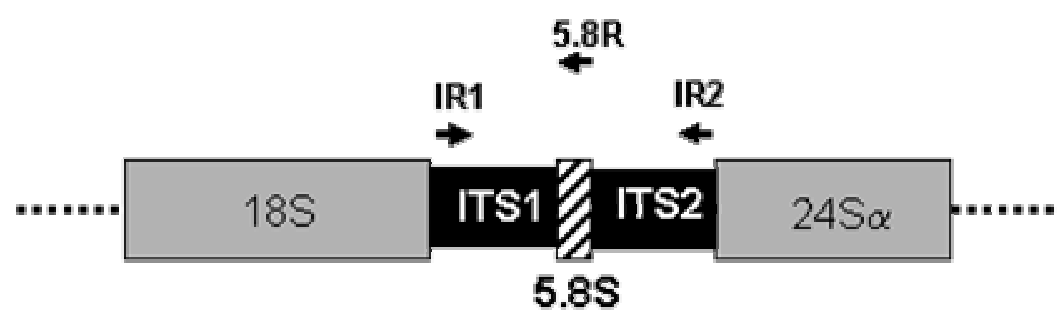

Figura 2: Representação esquemática do cistron ribossômico de tripanossomatídeos. IRI, IR2 e 5.8R indicam as sequências utilizadas para construção dos oligonucleotideos.

\subsection{Ligação}

A ligação foi realizada utilizando o kit "TOPO TA Cloning® kit for sequencing" (Invitrogen $^{\mathrm{TM}}$ ) onde foi adicionado $1 \mu \mathrm{L}$ do produto de PCR, $3 \mu \mathrm{L}$ de água, $1 \mu \mathrm{L}$ solução salina e $1 \mu \mathrm{L}$ de TOPO. A mistura foi incubada a temperatura ambiente por $10 \mathrm{~min}$.

\subsection{Preparação da bactéria competente}

Para preparação da bactéria competente foi utilizado o método descrito por Cohen e colaboradores (1972), que baseia-se no tratamento das bactérias com cloreto de cálcio.

Um inóculo de bactérias preparado em $3 \mathrm{~mL}$ de meio LB (triptona 1\%; extrato de levedura $0,5 \% ; \mathrm{NaCl} 0,18 \mathrm{M}$ ) foi acrescido dos antibióticos apropriados e incubados a 37 o $C$ por $16 \mathrm{~h}$ sob agitação. Em seguida, $500 \mu \mathrm{L}$ da cultura foram inoculados em $100 \mathrm{~mL}$ de meio LB e incubados a $37^{\circ} \mathrm{C}$ sob agitação até atingir $\mathrm{DO}_{600}$ entre 0,3 e 0,6 . As células foram incubadas no gelo por 5 a 10 min e centrifugadas a $3.000 \times g$ por 10 min a $4{ }^{\circ} \mathrm{C}$. $\mathrm{O}$ sobrenadante foi desprezado e o sedimento foi ressuspenso na metade do volume original com $50 \mathrm{mM} \mathrm{CaCl}_{2}$ gelado. As células foram centrifugadas como descrito acima e o sedimento ressuspenso em volume $(\mathrm{mL})$ correspondente a 10 vezes o valor obtido para $\mathrm{DO}_{600}$ de $50 \mathrm{mM} \mathrm{CaCl}$ e $15 \%$ de glicerol. As bactérias competentes $(200 \mu \mathrm{L}$ ) foram aliquotadas e armazenadas a $-70 \stackrel{\circ}{\mathrm{C}}$. 


\subsection{Transformação}

Após a ligação, o DNA foi misturado a $200 \mu \mathrm{L}$ de bactéria competente Escherichia coli $(\mathrm{DH} 5 \alpha)$ e incubado no gelo por $20 \mathrm{~min}$. Logo em seguida a mistura foi submetida a choque térmico a $42 \stackrel{\circ}{\circ}$ por 90 segundos e novamente incubada em gelo por 3 min. Foram adicionados $800 \mu \mathrm{L}$ de meio LB e a mistura foi incubada a $37^{\circ} \mathrm{C}$ por $60 \mathrm{~min}$. Após esse período, a mistura foi centrifugada por $2 \min$ a $11.180 \times \mathrm{g}$, plaqueada em meio LB contendo ampicilina $100 \mu \mathrm{g} / \mathrm{mL}$ e mantida a $37^{\circ} \mathrm{C}$ por $16 \mathrm{~h}$.

\subsection{Purificação de DNA de plasmídeo (Miniprep)}

A cultura de bactérias $(1,5 \mathrm{~mL})$ foi centrifugada a $16.090 \times g$ por 1 min. $O$ sobrenadante foi descartado e o precipitado ressuspenso em $300 \mu \mathrm{L}$ da solução PI (Tris$\mathrm{HCl} 50 \mathrm{mM} \mathrm{pH}$ 8; EDTA $10 \mathrm{mM} \mathrm{pH}$ 8; RNase $100 \mu \mathrm{g} / \mu \mathrm{L})$. Em seguida foi adicionado 300 $\mu \mathrm{L}$ da solução PII ( $\mathrm{NaOH}$ 0,2 N; SDS 1\%) e incubado a temperatura ambiente por 5 min. Logo após, foi acrescentado $300 \mu \mathrm{L}$ da solução PIII (acetato de potássio $3 \mathrm{M} \mathrm{pH} \mathrm{5,5).} \mathrm{A}$ mistura foi centrifugada a $21.910 \times \mathrm{g}$ por $10 \mathrm{~min}$ e o sobrenadante recuperado. Foi adicionado $400 \mu \mathrm{L}$ isopropanol e centrifugado como descrito acima. O precipitado foi lavado com $600 \mu \mathrm{L}$ de etanol $70 \%$ e centrifugado novamente a 21.910 × g por $5 \mathrm{~min}$. $\mathrm{O}$ sobrenadante foi desprezado e o precipitado seco ressuspenso em $50 \mu \mathrm{L}$ de água.

\subsection{Sequenciamento de DNA}

O sequenciamento de DNA foi realizado segundo o método descrito por Sanger e Coulson (1975) com modificações para a utilização de terminadores fluorescentes. Utilizou-se o kit "Big dye ${ }^{\mathrm{tm}}$ Terminator Cycle Sequencing Ready Reaction Kit" (Applied Biosystems). Na reação foi utilizado $100 \mathrm{ng}$ dos iniciadores M13 Forward ou M13 Reverse e 100 ng de DNA de plasmídeo.

Condições de reação: 1 ciclo: 1 min a $96{ }^{\circ} \mathrm{C} ; 30$ ciclos: 15 seg a $96 \stackrel{\circ}{\circ}$; 15 seg a $50^{\circ} \mathrm{C} ; 4$ min a $60^{\circ} \mathrm{C}$.

O produto da reação de sequenciamento foi precipitado com $90 \mu \mathrm{L}$ de isopropanol $66 \%$, homogeneizado e incubado a temperatura ambiente por 15 min. Após incubação, as amostras foram centrifugadas a $15.300 \times \mathrm{g}$ por $20 \mathrm{~min}$, lavadas com etanol $70 \%$ 
gelado e processadas em um seqüenciador automático, aparelho ABI Prism 310 Genetic Analyser (Applied Biosystems).

\subsection{Análise das sequências de nucleotideos}

$\begin{array}{lllccc}\text { Seqüências de nucleotídeos das regiões } & \text { ITS1 } & 5.8 S \text { e ITS2 do isolado } \\ \text { EFSF/06/GO } & \text { foram } \quad \text { analisadas } & \text { no } & \text { programa } & \text { BioEdit }\end{array}$
(http://www.mbio.ncsu.edu/BioEdit/bioedit.html) e alinhadas com as seqüências de diferentes espécies de Leishmania obtidas do GeneBank. O alinhamento foi realizado com o auxílio do programa ClustalW (www.ebi.ac.uk/clustalw) e a árvore de máxima parcimônia foi construída utilizando o programa PAUP* 4.0 (SWOFFORD, 1998).

\subsection{Drogas}

Antimoniato de meglumina $\left(\right.$ Glucantime $\left.^{\circledR}\right)$ foi cedido pela Sanofi-Aventis. Anfotericina B desoxicolato de sódio e tamoxifeno foram adquiridos da Sigma-Aldrich. As diluições das drogas foram realizadas em meio RPMI (antimoniato de meglumina), água (anfotericina B) e etanol (tamoxifeno).

\subsection{Avaliação da atividade de drogas contra promastigotas de Leishmania sp.}

\subsubsection{Análises de turvação}

Os ensaios de turvação foram realizados incubando-se os promastigotas de fase logarítmica em placas de 96 poços e a leitura foi realizada em leitor de ELISA medindo a absorbância a 595 nm, 620 e 595 usando-se como referência 690 nm.

\subsubsection{Teste de MTT clássico}

No teste de MTT descrito por Moreira et al. (1996) utilizou-se promastigotas de fase logarítmica $\left(5 \times 10^{6} / \mathrm{mL}\right)$ que foram incubados por $24 \mathrm{~h}$ em placas de 24 poços com diferentes concentrações de droga. Após o período de incubação, as culturas foram transferidas para tubos tipo eppendorf e centrifugadas a $1.000 \times g$ por $5 \mathrm{~min}$. $O$ sobrenadante foi desprezado e as células lavadas 3 vezes com $1 \mathrm{~mL}$ de tampão $A(\mathrm{NaCl}$ 
$116 \mathrm{mM}, \mathrm{KCl}$ 5,4 mM, $\mathrm{MgSO}_{4}$ 0,8 mM, glicose 5,5 mM e MOPS $\left.10 \mathrm{mM}\right)$. Após lavagens, o sedimento foi ressuspenso em $100 \mu \mathrm{L}$ de tampão A e $20 \mu \mathrm{L}$ de 3-(4,5-dimetiltiazol-2-il)2,5 difenil bromo tetrazolium (MTT) $5 \mathrm{mg} / \mathrm{mL}$ e incubados por $2 \mathrm{~h}$ a $25^{\circ} \mathrm{C}$. A reação foi interrompida pela adição de $200 \mu \mathrm{L}$ de dodecil sulfato de sódio (SDS) $10 \%$. O conteúdo de cada poço foi homogeneizado e transferido $200 \mu \mathrm{L}$ para placa de 96 poços. A leitura foi realizada em leitor de ELISA, medindo-se a absorbância a $595 \mathrm{~nm}$, utilizando-se como referência $690 \mathrm{~nm}$.

\subsubsection{Microteste de MTT}

O teste de MTT foi modificado a partir do método descrito por Moreira et al. (1996). Promastigotas de fase logarítmica tardia (3 ou 4 dias de cultura) foram coletados por centrifugação a $1000 \times$ g por 10 min e ressuspensos em meio 199 para concentração de $2 \times 10^{7} / \mathrm{mL}$. Em uma placa de 96 poços foi distribuído em triplicata $150 \mu \mathrm{L}$ da suspensão contendo $3 \times 10^{6}$ parasitas. Concentrações crescentes das drogas foram adicionadas logo em seguida e a placa foi incubada a $25 \stackrel{\circ}{\mathrm{C}}$ por $24 \mathrm{~h}$. Após o período de incubação, foi acrescentado $30 \mu \mathrm{L}$ de MTT $5 \mathrm{mg} / \mathrm{mL}$. A suspensão foi incubada por $2 \mathrm{~h}$ a $25 \stackrel{\circ}{\circ}$. A reação foi interrompida adicionando-se $50 \mu \mathrm{L}$ de SDS $20 \%$ e homogeneizandose o conteúdo de cada poço. A leitura foi realizada em leitor de ELISA medindo-se a absorbância a $595 \mathrm{~nm}$ e usando-se como referência $690 \mathrm{~nm}$. A mitocôndria do parasita vivo converte o MTT em um produto corado denominado formazan, que pode ser medido espectrofotometricamente (MOSMANN, 1983). O teste foi realizado com todos os isolados de $L$. (V.) braziliensis e $L$. (L.) amazonensis e com o isolado MAB/03/PA de $L$. major-like, com o isolado de $L$. (V.) braziliensis MHOM/BR/01/BA coletado no estado da Bahia e com as linhagens referência $L$. (V.) braziliensis MHOM/BR/1975/M2903 e L. (L.) amazonensis MHOM/BR/1973/M2269. Os parasitas foram tratados com anfotericina B, tamoxifeno e Glucantime $\AA$. Os experimentos com cada isolado foram repetidos independentemente pelo menos 2 vezes e foram sempre realizados em paralelo com a linhagem referência.

Para as análises de $\mathrm{Cl}_{50}$ e $\mathrm{Cl}_{90}$ (concentração da droga que inibe 50 e 90\% da viabilidade celular) foi utilizado o programa Origin 7.5. 


\subsection{Cultivo de macrófagos}

As linhagens de macrófagos J774 A.1 e THP-1 foram cedidas pela Dra . Sonia Jancar Negro e $\mathrm{Dr}^{\mathrm{a}}$. Ises de Almeida Abrahamsohn, respectivamente, do Departamento de Imunologia (ICB-USP). Esses macrófagos foram mantidos em meio RPMI 1640 (Invitrogen) suplementado com $10 \%$ de soro fetal bovino (SFB) em estufa a $37 \stackrel{\circ}{ } \mathrm{C}$ com atmosfera de $5 \% \mathrm{CO}_{2}$.

\subsection{Macrófagos residentes de peritônio de camundongos BALB/c}

Fêmeas de camundongos BALB/c foram sacrificadas em câmara de $\mathrm{CO}_{2}$. Após exposição do abdômen para perfuração do peritônio, procedeu-se à lavagem da cavidade peritoneal com $3 \mathrm{~mL}$ de meio RPMI completo gelado. O procedimento foi repetido quatro vezes e o material recolhido foi mantido em gelo. Em seguida, as células foram centrifugadas a $300 \times \mathrm{g}$ por 10 min a $4 \stackrel{\circ}{\circ}$, ressuspensas em meio RPMl completo gelado e plaqueadas.

\subsection{Obtenção de macrófagos de medula}

Segundo o método descrito por Zamboni e Rabinovitch (2003), camundongos $\mathrm{BALB} / \mathrm{c}$ foram sacrificados em câmara de $\mathrm{CO}_{2}$. O fêmur de cada pata foi retirado e as epífises cortadas. Uma agulha $21 \mathrm{G}$ conectada a seringa de $5 \mathrm{~mL}$ foi introduzida no canal medular que foi lavado com $5 \mathrm{~mL}$ de meio R2030. O material foi armazenado em placa de Petri de poliestireno (Optilux ${ }^{\mathrm{TM}}$ ) e mantido a $37{ }^{\circ} \mathrm{C}$ com atmosfera de $5 \% \mathrm{CO}_{2}$ por 7 dias. Para cada fêmur foi utilizada uma placa, acrescentando-se mais $10 \mathrm{~mL}$ de meio R2030 no terceiro ou quarto dia. Após esse período, os $16 \mathrm{~mL}$ de meio foram descartados e adicionado $5 \mathrm{~mL}$ de meio RPMl sem soro gelado. As placas contendo macrófagos aderidos foram incubadas em gelo por 15 min e os macrófagos descolados com cell scraper (Corning Inc. ${ }^{\circledR}$ ). O material foi centrifugado a $60 \times \mathrm{g}$ por $10 \mathrm{~min}$ a $4{ }^{\circ} \mathrm{C}$ e ressuspenso em meio R105. As células foram contadas em câmara de Neubauer e plaqueadas.

O meio R2030 foi preparado com $50 \%$ de meio RPMI, $20 \%$ de soro fetal bovino (SFB) e 30\% do sobrenadante de cultura de fibroblasto L929. O meio R105 foi preparado com $85 \%$ de meio RPMI, $10 \%$ de soro fetal bovino (SFB) e $5 \%$ do sobrenadante de 
cultura de fibroblasto L929. As células L929 foram cedidas pela Dra . Marta Maria Geraldes Teixeira do Departamento de Parasitologia (ICB - USP) e cultivadas em DMEN (Dulbecco`s modified Eagle`s medium) (Sigma Chemical) suplementado com $10 \%$ de SFB a $37^{\circ} \mathrm{C} 5 \% \mathrm{CO}_{2}$.

\subsection{Avaliação da atividade de drogas contra amastigotas intracelulares}

\subsubsection{Macrófagos de peritônio e J774 A.1}

Os macrófagos J774 A.1 e macrófagos extraídos de peritônio de camundongos foram cultivados em placas de 24 poços contendo lamínulas de $13 \mathrm{~mm}$ de diâmetro. Em cada poço foram adicionados $4 \times 10^{5}$ macrófagos de linhagem J774 A.1 que foram mantidos por $2 \mathrm{~h}$ em estufa a $37 \stackrel{\circ}{\mathrm{C}} \mathrm{com}$ atmosfera de $5 \% \mathrm{CO}_{2}$ para aderirem nas lamínulas. Já as células extraídas de peritônio foram mantidas por $24 \mathrm{~h}$ nas mesmas condições. Após esse período as células foram lavadas com PBS $\left(\mathrm{NaH}_{2} \mathrm{PO}_{4} 2,6 \mathrm{mM}\right.$; $\mathrm{Na}_{2} \mathrm{HPO}_{4} 7,4 \mathrm{mM}$; $\mathrm{NaCl} 137 \mathrm{mM}$ pH 7,2) a $37 \stackrel{\circ}{\mathrm{C}}$ para remoção das células não aderentes. Os macrófagos foram infectados com promastigotas de L. (V.) braziliensis MHOM/BR/1975/M2903 em proporções de 5:1, 10:1 e 15:1 (parasitas: macrófago). O período de incubação variou de 3 a $24 \mathrm{~h}$ em estufa a $33 \stackrel{\circ}{\circ} \mathrm{C}$ com atmosfera de $5 \% \mathrm{CO}_{2}$. Após internalização, a cultura foi lavada 3 vezes com PBS pré-aquecido a $33^{\circ} \mathrm{C}$ e em seguida incubada em RPMI completo a $33^{\circ} \mathrm{C}$ na presença das drogas analisadas. Após $24 \mathrm{~h}$ o meio e a droga foram trocados. Depois de $72 \mathrm{~h}$ de experimento, a cultura foi novamente lavada com PBS a $33^{\circ} \mathrm{C}$ e as células foram fixadas com metanol por 1 min e coradas com o conjunto de corantes Instant Prov (Newprov). As lâminas foram observadas ao microscópio óptico avaliando-se a porcentagem de células infectadas e o número de amastigotas por célula.

\subsubsection{Macrófagos THP-1}

Macrófagos THP-1 (6 × 105/mL) de linhagem leucêmica humana foram distribuídos em placa de 24 poços contendo lamínulas de $13 \mathrm{~mm}$ de diâmetro. Para adesão e ativação dos macrófagos nas lamínulas foi utilizado $20 \mathrm{nM}$ de PMA (forbol miristato acetato). A placa foi incubada em estufa a $37 \stackrel{\circ}{\circ} \mathrm{com} 5 \% \mathrm{CO}_{2}$ durante $48 \mathrm{~h}$. Após esse período, os poços foram lavados 2 vezes com PBS a $33^{\circ} \mathrm{C}$ e adicionado 
promastigotas de L. (V.) braziliensis MHOM/BR/1975/M2903 na proporção de 10 parasitas por macrófago.

\subsubsection{Macrófagos de medula}

Macrófagos de medula foram cultivados em placas de 24 poços contendo lamínulas de $13 \mathrm{~mm}$ de diâmetro. Cada lamínula recebeu $3 \times 10^{5}$ macrófagos que foram mantidos por $24 \mathrm{~h}$ em estufa a $37 \stackrel{\circ}{\circ} \mathrm{C}$ com atmosfera de $5 \% \mathrm{CO}_{2}$ para aderirem nas lamínulas. Após esse período as células foram lavadas com PBS pré-aquecido a $37 \stackrel{\circ}{ } \mathrm{C}$. Os macrófagos foram infectados com promastigotas de Leishmania em proporções de 10:1 (parasitas: macrófago) por $3 \mathrm{~h}$ em estufa a $33^{\circ} \mathrm{C}$ com atmosfera de $5 \% \mathrm{CO}_{2}$. Após a infecção, a cultura foi lavada 2 vezes com RPMI sem soro a $33 \stackrel{\circ}{\circ}$ e adicionado meio R105 a $33^{\circ} \mathrm{C}$ na presença das drogas analisadas. Cada concentração de droga foi avaliada em triplicata e em pelo menos dois experimentos independentes. Os macrófagos infectados foram tratados por 6 dias trocando-se o meio e a droga no terceiro dia. Após esse período, a cultura foi novamente lavada com PBS pré-aquecido a $33^{\circ} \mathrm{C}$ e as células foram fixadas com metanol por 1 min e coradas com o conjunto de corantes Instant Prov (Newprov). As lâminas foram observadas ao microscópio óptico. Para as análises de $\mathrm{Cl}_{50}$ e $\mathrm{Cl}_{90}$ (concentração da droga que inibe 50 e $90 \%$ da viabilidade celular) foi utilizado o programa Origin 7.5.

\subsubsection{Ensaios de citotoxicidade}

Macrófagos de medula $\left(5 \times 10^{6}\right.$ macrófagos $\left./ \mathrm{mL}\right)$ em $400 \mu \mathrm{L}$ de meio R105 foram incubados em placas de 24 poços por $24 \mathrm{~h}$ em estufa a $37^{\circ} \mathrm{C}$ e $5 \%$ de $\mathrm{CO}_{2}$. Em seguida foram adicionadas concentrações de 10, 15 e $20 \mu \mathrm{M}$ de tamoxifeno e 135, 405 e 810 $\mu \mathrm{g} / \mathrm{mL}$ de $\mathrm{Sb}^{v}$ por 6 dias trocando o meio e a droga no terceiro dia. A placa foi mantida em estufa a $33{ }^{\circ} \mathrm{C}$ e $5 \%$ de $\mathrm{CO}_{2}$. Ao término desse período, as células foram lavadas com tampão A pré aquecido e a seguir incubados com MTT em tampão A (60 $\mu \mathrm{L}$ de MTT $5 \mathrm{mg} / \mathrm{mL}$ e $180 \mu \mathrm{L}$ de tampão A). A placa foi incubada por $2 \mathrm{~h}$ em estufa a $33^{\circ} \mathrm{C}$ e $5 \%$ de $\mathrm{CO}_{2}$. A reação foi interrompida adicionando-se $100 \mu \mathrm{L}$ de dodecil sulfato de sódio (SDS) $20 \%$ e homogeneizando-se o conteúdo de cada poço. A leitura foi realizada em leitor de ELISA medindo-se a absorbância a $595 \mathrm{~nm}$ e usando-se como referência $690 \mathrm{~nm}$. 


\subsection{Camundongos BALB/C}

Fêmeas de camundongos BALB/c com aproximadamente 4 semanas de idade foram adquiridos do biotério do Departamento de Parasitologia (ICB - USP).

\subsection{Infecção de camundongos BALB/c com isolados de $L$. (V.) braziliensis}

Camundongos fêmeas da linhagem BALB/c foram separados em grupos de 6 ou 7 para inoculação de $1 \times 10^{5}$ e $5 \times 10^{5}$ promastigotas de $L$. (V.) braziliensis MHOM/BR/01/BA e UAF/06/TO. Os parasitas foram inoculados por via intradérmica na orelha esquerda (10 $\mu \mathrm{L}$ salina $0,9 \%$ contendo $1 \times 10^{5}$ promastigotas) ou por via subcutânea na pata posterior esquerda ou na base da cauda ( $50 \mu \mathrm{L}$ salina $0,9 \%$ contendo $5 \times 10^{5}$ promastigotas). Para medir as lesões foi utilizado um paquímetro (Mitutoyo). O diâmetro da cauda e a espessura da pata e orelha foram medidas semanalmente por 12 semanas.

\subsection{Tratamento de camundongos BALB/c infectados com $L$. (V.) braziliensis}

Grupos de 6 ou 7 camundongos BALB/c fêmeas foram inoculados com $1 \times 10^{5}$ promastigotas de L. (V.) braziliensis MHOM/BR/01/BA na orelha esquerda. O tratamento iniciou-se 21 dias após o inóculo dos parasitas. Os camundongos receberam citrato de tamoxifeno ou Glucantime ${ }^{\circledR}(20 \mathrm{mg} / \mathrm{Kg} /$ dia por 15 dias consecutivos) ou anfotericina B $(0,5 \mathrm{mg} / \mathrm{Kg} / \mathrm{dia}$ por 12 dias alternados) por via intraperitoneal. O grupo controle recebeu somente salina por 15 dias consecutivos. Estes testes foram realizados três vezes independentemente.

O tratamento por via tópica foi realizado com tamoxifeno $20 \mathrm{mg} / \mathrm{Kg} /$ dia diluído em $10 \%$ de glicerol e $90 \%$ de etanol, aplicando-se com pipeta $10 \mu \mathrm{L}$ da droga no local da lesão. Um grupo de camundongos recebeu somente a solução de glicerol com etanol. Os animais receberam 12 doses de droga, sendo 7 consecutivas na primeira semana e 5 doses diárias após um intervalo de 7 dias. A espessura da orelha foi medida semanalmente durante 12 semanas. 


\subsection{Quantificação de parasitas por diluição limitante}

Foram sacrificados 3 ou 4 camundongos de cada grupo: controle não tratado, tratados com anfotericina B ou Glucantime ${ }^{\circledR}$ ou tamoxifeno. A orelha foi recortada isolando-se o tecido na região da lesão que foi homogeneizado com $1 \mathrm{~mL}$ de PBS estéril. O material foi armazenado em gelo para posterior centrifugação a $60 \times g$ por 8 min e recolhimento do sobrenadante. Em seguida, foi realizada nova centrifugação a $600 \times g$ por $10 \mathrm{~min}$ e o sedimento foi ressuspenso em $1 \mathrm{ml}$ de meio 199. As células foram contadas em câmara de Neubauer e distribuído $150 \mu \mathrm{L}$ no primeiro poço de uma placa de 96 poços contendo $50 \mu \mathrm{L}$ de meio 199. A partir disso, foram realizadas diluições sucessivas de $20 \mu \mathrm{L}$ até o último poço, sendo que a todos os poços foram adicionados $180 \mu \mathrm{L}$ de meio 199. As placas foram incubadas por 7 dias a $25 \stackrel{\circ}{\circ}$ para posterior verificação de crescimento das culturas e quantificação de parasitas (LIMA et al., 1997). O teste foi feito em triplicata e os dados analisados utilizando-se o programa ELIDA.

\subsection{Exame histopatológico}

Tecido da orelha de camundongos tratados e não tratados foram removidos e fixados em formaldeído 10\% em PBS. O material foi incluído em parafina, as lâminas coradas com hematoxilina-eosina (HE) e analisadas por microscopia óptica.

\subsection{Avaliação macroscópica}

Os camundongos foram fotografados com câmara digital Sony 7.2 M.

\subsection{Microscopia eletrônica de transmissão}

Os experimentos de microscopia eletrônica de transmissão foram realizados no laboratório da Profa . Alcira Tânia Bijovsky Katzin pelo técnico Alexandre Santos de Moura (Departamento de Parasitologia/ICB - USP).

Promastigotas de fase logarítmica $\left(5 \times 10^{7} / \mathrm{mL}\right)$ foram lavados em meio RPMI sem soro e, promastigotas ou fragmentos de tecido (orelha do camundongo) foram fixados em solução contendo $0,5 \%$ de glutaraldeído, $4 \%$ de paraformaldeído em tampão cacodilato de sódio $0,1 \mathrm{M}, \mathrm{pH} 7,2$, com $\mathrm{CaCl}_{2} 0,5 \mathrm{mM}$ e solução saturada de ácido pícrico $0,2 \%$ por 5 
min a temperatura ambiente e por $1 \mathrm{~h}$ a $4{ }^{\circ} \mathrm{C}$. Os parasitas foram lavados com TBS $\mathrm{pH}$ 7,2 (Tris- $\mathrm{HCl} 20 \mathrm{mM}$; $\mathrm{NaCl} 150 \mathrm{mM}$; $\mathrm{NaN}_{3} 0,01 \%$ ), centrifugados a 8.000 x g a $4 \stackrel{\circ}{\circ} \mathrm{C}$ por 20 min. O precipitado foi desidratado em etanol $70 \%$ e incluído em resina LR-White hard grade (The London Resin Co LTD). As amostras foram observadas em microscópio eletrônico de transmissão JEOL 100CX II.

\subsection{Microscopia eletrônica de varredura}

Estes experimentos foram realizados pela $\mathrm{Dr}^{\mathrm{a}}$. Juliany Cola Rodrigues no laboratório do Prof. Dr. Wanderley de Souza (Instituto de Biofísica Carlos Chagas Filho, Universidade Federal do Rio de Janeiro).

Os parasitas $\left(2 \times 10^{8} / \mathrm{mL}\right)$ foram lavados duas ou três vezes em PBS e fixados com solução contendo $2.5 \%$ glutaraldeído (EMS) em $0.1 \mathrm{M}$ de tampão cacodilato (EMS), $\mathrm{pH}$ 7.2. As células foram novamente fixadas com $1 \%$ tetróxido de ósmio $\left(\mathrm{OsO}_{4}\right)$ (Polysciences) e 1,25\% ferrocianeto de potássio em $0.1 \mathrm{M}$ de tampão cacodilato e desidratadas com etanol. As amostras foram analisadas em microscópio eletrônico de varredura JEOL 5310.

\subsection{Imunofluorescência}

Para preparação das lâminas, promastigotas de fase logarítmica $\left(1 \times 10^{6} / \mathrm{mL}\right)$ foram centrifugados a $1.000 \times \mathrm{g}$ por $10 \mathrm{~min}$ e lavados em PBS. Foram aplicados $10 \mu \mathrm{L}$ em cada poço da lâmina. Após secos foram fixados com metanol por 15 min a temperatura ambiente e lavados três vezes com PBS. Em seguida, as lâminas foram bloqueadas com PBS/ 2\% BSA (albumina sérica bovina) por $30 \mathrm{~min}$ a temperatura ambiente e lavadas três vezes com PBS. Os anticorpos utilizados foram diluídos em PBS/ 2\% BSA na proporção de 1:80 ( $\alpha$-tubulina) e 1:5 (SST-3) (SILVEIRA et al., 2003) e incubados em câmara úmida a $37^{\circ} \mathrm{C}$ por $30 \mathrm{~min}$. Após quatro lavagens com PBS, foi adicionado o anticorpo secundário, anti IGg, marcado com Rodamina B, diluído 1:400 em PBS/ 2\% BSA e incubados a $37^{\circ} \mathrm{C}$ em câmara úmida por $30 \mathrm{~min}$. Seguiram-se quatro lavagens com PBS. Núcleo e cinetoplasto foram marcados com DAPI 2,5 $\mu \mathrm{g} / \mathrm{mL}$ em PBS por 1 min. Após 4 lavagens com PBS aplicou-se Fluoromount G (EMS) e cobriu-se com lamínula. As lâminas foram observadas em microscópio de fluorescência utilizando filtro de 546 nm (Rodamina B). 


\subsection{Estatística}

As análises estatísticas foram realizadas através do programa GraphPad Prism, CA, USA (one-way ANOVA e Dunnett's post hoc test). O valor de $P<0,05$ foi considerado estatisticamente significativo. 
Resultados 


\section{Resultados}

\subsection{Condições de cultivo dos isolados}

Todos os isolados foram obtidos de pacientes com leishmaniose cutânea e inicialmente foram mantidos em meio de Grace. As culturas foram congeladas logo após 0 isolamento e foram recebidas com um baixo número de passagens. As cepas recebidas foram transferidas para meio 199 contendo 2\% de urina masculina humana estéril e 20\% de soro fetal bovino (SFB) mostrando boa adaptação neste meio. Durante as primeiras passagens mantivemos culturas em paralelo em meio de Grace, mas o crescimento de promastigotas nesse meio foi inferior ao observado em meio 199.

Após 4 semanas de cultivo em meio 199 contendo $2 \%$ de urina masculina humana estéril e $20 \%$ SFB, retirou-se $10 \%$ de SFB e os $2 \%$ de urina. As culturas dos isolados de Leishmania (L.) amazonensis mantiveram-se normalmente em meio 199 contendo somente $10 \%$ de SFB. Já as culturas de Leishmania (V.) braziliensis cresceram normalmente por uma semana e depois mostraram redução de crescimento sendo necessário adicionar novamente $2 \%$ de urina no meio para cultivo dos parasitas dessa espécie. Alíquotas das culturas de todos os isolados foram congeladas assim que recebidas e mantidas com repiques semanais pelo menor número possível de passagens para a realização dos experimentos.

\subsection{Confirmação da identificação dos isolados de Leishmania spp.}

Os isolados foram recebidos após terem sido tipados no laboratório da Profa. Lucile Maria Floeter-Winter (Instituto de Biociências, USP), por amplificação de DNA do gene ribossômico e G6PD (Glucose-6 fosfato desidrogenase) (ULIANA et al., 1994; CASTILHO et al., 2003). Os isolados tinham sido todos tipados como L. (V.) braziliensis ou $L$. (L.) amazonensis. Decidimos obter uma confirmação independente da identificação de todas as culturas em nosso laboratório. Para isso, desenhamos um método de tipagem baseado em análise de polimorfismo de restrição de produto amplificado a partir do gene META2. A comparação da sequência de nucleotídeos dos genes META2 de $L$. (L.) amazonensis (RAMOS et al., 2004), L. (L.) major e L. (V.) braziliensis (disponíveis em www.genedb.org) revelou a existência de sítios de restrição para a enzima Xho I que permitiam diferenciar as 3 espécies (Figura 3). 

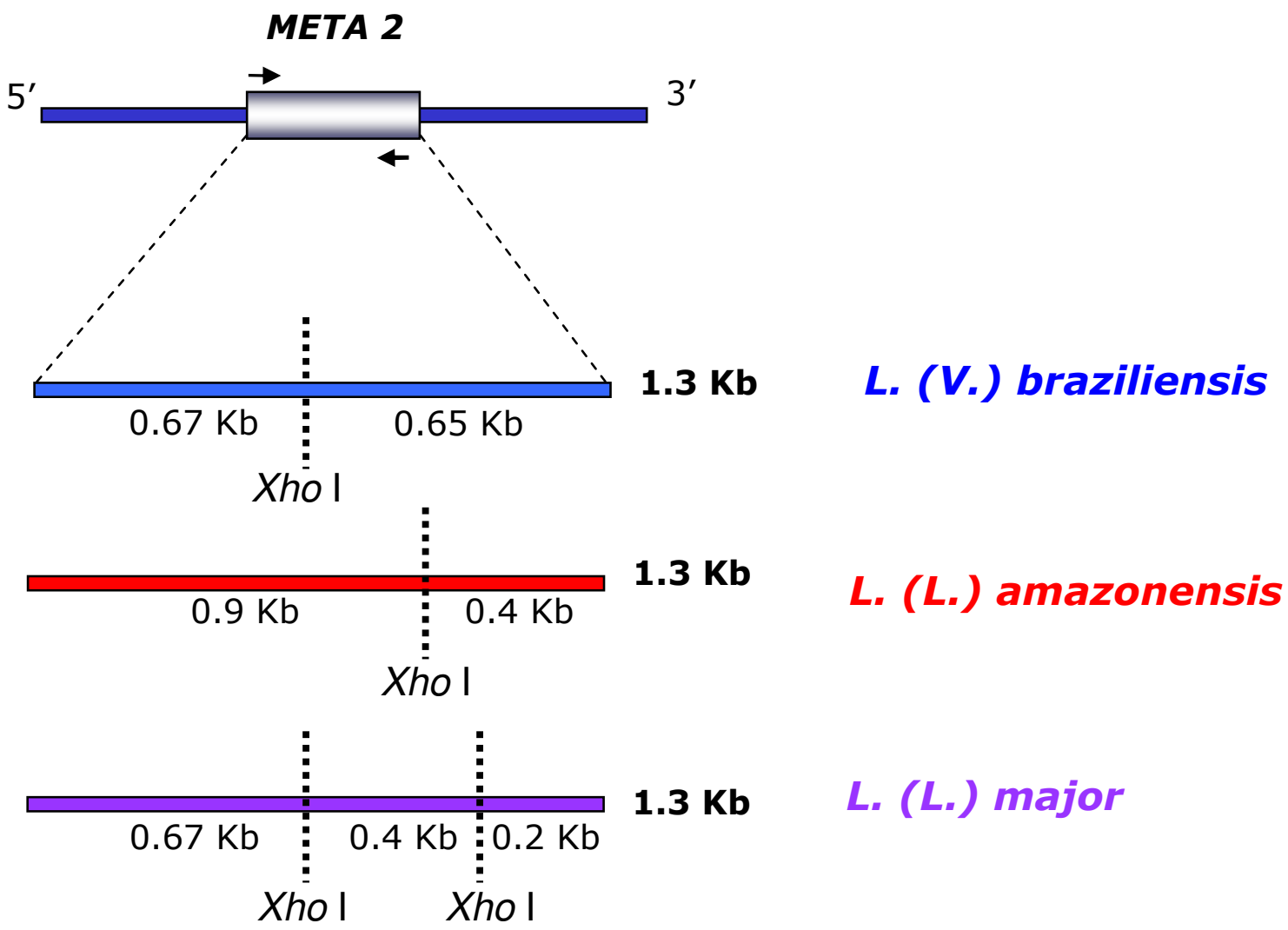

Figura 3: Esquema representativo da sequência da ORF do gene META2 de Leishmania e dos sítios de clivagem para a enzima Xho I na sequência de $L$. (V.) braziliensis, $L$. (L.) amazonensis e L. (L.) major. 
Após extração de DNA genômico foi realizada reação de PCR utilizando iniciadores complementares às extremidades 5' e 3' da fase aberta de leitura (ORF) do gene META2, como descrito em Materiais e Métodos. Em seguida, os produtos de PCR foram clivados com a enzima Xho I e analisados por eletroforese em gel de agarose $1,5 \%$. Através do polimorfismo de restrição foi possível diferenciar a qual espécie de Leishmania pertencia cada isolado. Esse método permitiu confirmar a tipagem dos isolados BES/06/GO, EFSF/06/GO, GDL/06/GO, HPV/06/TO, IMG/03/GO, PPS/06/BA, RPL/05/GF, TMB/06/GO, UAF/06/TO e WSS/05/GO como L. (V.) braziliensis e JRS/01/GO, JSC/06/PA e EGS/04/GO como L. (L.) amazonensis (Figura 4 A, B, D e E). O padrão de amplificação e restrição obtido com DNA dos isolados MAB/03/PA e VBL/01/PA não era compatível com a tipagem prévia de L. (L.) amazonensis e sugeria identificação como L. (L.) major.

Tendo em vista que 2 dos isolados apresentaram padrões de amplificação e restrição diferentes dos esperados de acordo com a tipagem prévia (Figura 4 C e F) e sugestivos de L. (L.) major, decidimos confirmar os resultados do PCR para o gene META2 com outro método. A tipagem desses isolados foi então confirmada por ensaio com anticorpos monoclonais realizado pela professora Dra. Edna Ishikawa, da Universidade Federal do Pará. Foi testado um painel de 16 anticorpos monoclonais (B2, B5, B11, B12, B18, B19, M2, T3, CO2, L1, WIC, W1, W2, N2, N3 e WA2) sendo que os anticorpos da série $\mathrm{B}$ e $\mathrm{N}$ reagem com espécies de Leishmania do subgênero Viannia, M2, T3, WIC, WA2 reagem com espécies de Leishmania do subgênero Leishmania e CO2 e L1 reagem com espécies dos subgêneros Viannia e Leishmania. A tipagem de mais 2 isolados de L. (V.) braziliensis (UAF/06/TO e EFSF/06/GO) confirmados por PCR também foi avaliada por ensaio com anticorpos monoclonais porque esses dois isolados seriam utilizados em ensaios in vivo.

Os resultados confirmaram a identificação de isolados de L. (V.) braziliensis (UAF/06/TO e EFSF/06/GO) e L. major-like (VBL/01/PA e MAB/03/PA) (dados não apresentados). 
A

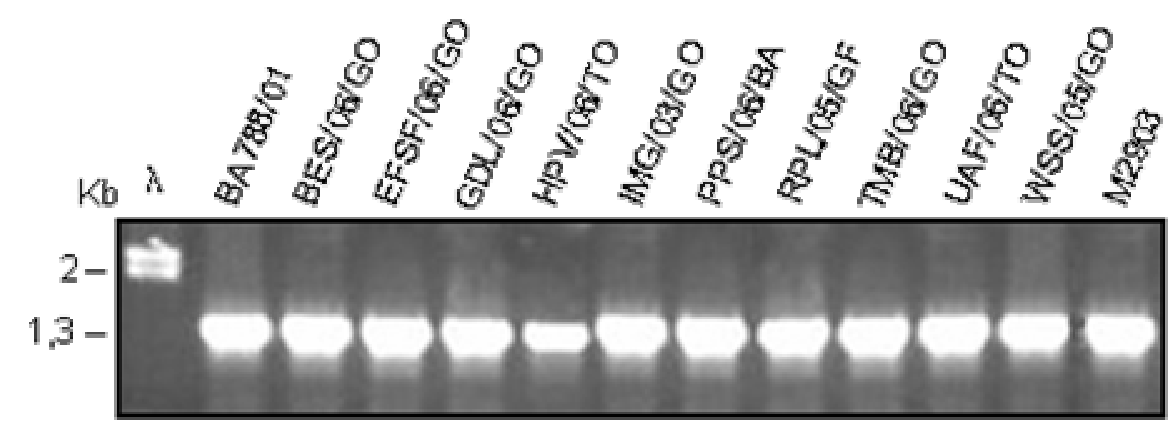

D

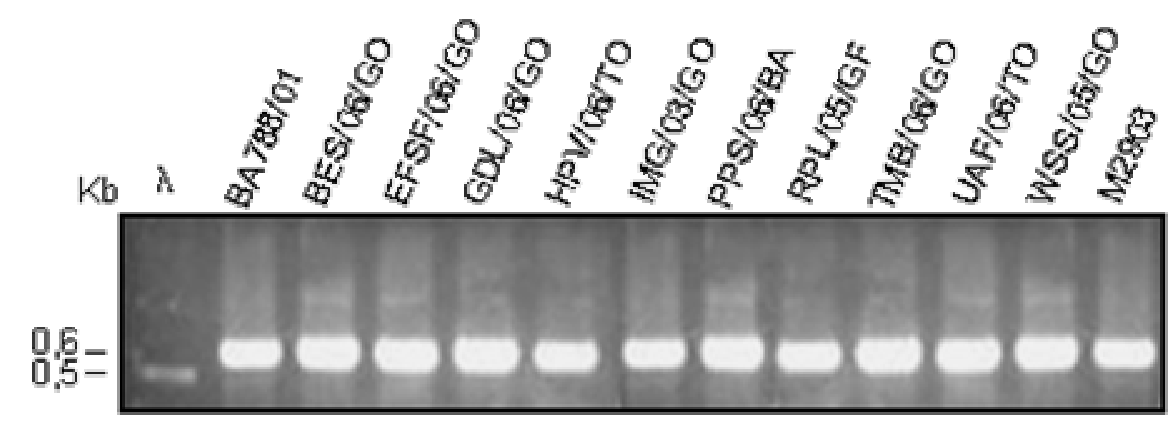

\section{B}

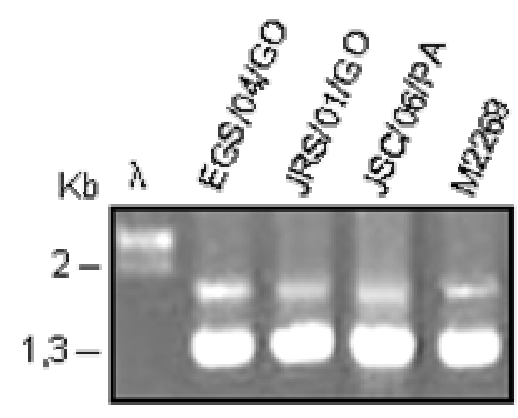

E

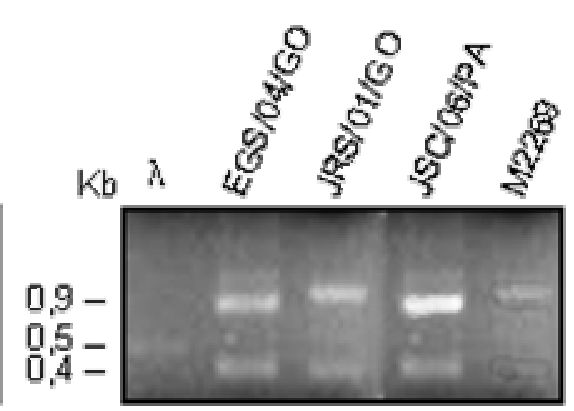

C

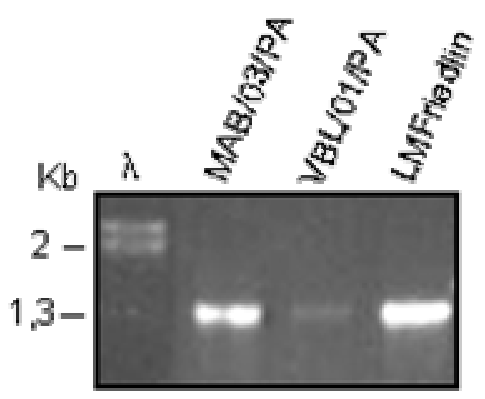

$\mathbf{F}$

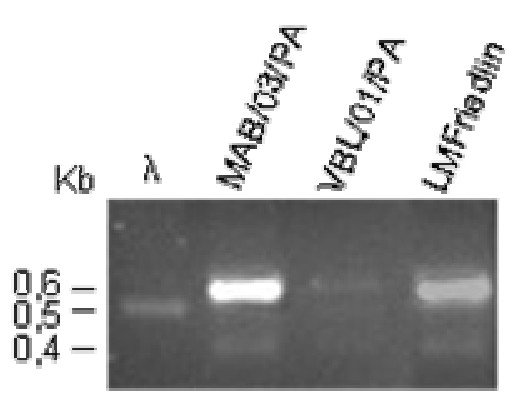

Figura 4: Identificação dos isolados utilizando como marcador molecular o gene META2. Eletroforese de DNA em gel de agarose 1,5\%. Reação de PCR com DNA de isolados de L. (V.) braziliensis (A), L. (L.) amazonensis (B) e L. major-like (C). As reações foram realizadas com oligonucleotídeos complementares à sequência do gene META2 de L. (V.) braziliensis (A) e L. amazonensis (B e C). Polimorfismo de restrição do produto da PCR de L. (V.) braziliensis (D), L. (L.) amazonensis (E) e L. major-like (F) com a enzima Xho I. 


\subsection{Padronização do teste de sensibilidade de promastigotas a drogas}

Antes de iniciar as determinações de sensibilidade a drogas utilizando promastigotas, testamos alguns métodos de avaliação com o objetivo de definir uma técnica rápida e pouco dispendiosa para utilização nos testes com isolados.

\subsubsection{Medida da turvação}

A atividade de drogas foi avaliada através da medida de turvação do meio como é utilizado para avaliar a sensibilidade de bactérias. Diferentes números de promastigotas de $L$. (L.) major $\left(1 \times 10^{6}, 1 \times 10^{7}, 3 \times 10^{7}, 6 \times 10^{7}\right.$ e $\left.1 \times 10^{8} / \mathrm{mL}\right)$ em $150 \mu \mathrm{L}$ de meio 199 (M199) ou tampão A (TA) foram distribuídas em placa de 96 poços e realizada a leitura de absorbância a $595 \mathrm{~nm}$ e $620 \mathrm{~nm}$. Os valores da D.O. variaram bastante entre as triplicatas tanto em meio 199 como em tampão A. Quando foi calculada a média desses valores, observou-se o aumento do valor da D.O. quando aumentava-se o número de células em meio 199 e tampão A. Entretanto, a D.O. do controle contendo somente M199 ou TA foi maior do que a D.O. desses meios contendo $1 \times 10^{7}$ parasitas/ mL. Portanto, a medida da turvação nesses meios não é confiável principalmente quando é utilizado um número baixo de parasitas. Não foi observada diferença significativa entre as leituras realizadas a $595 \mathrm{~nm}$ e $620 \mathrm{~nm}$ (Figura 5).

Após análise da turvação nos dois meios contendo diferentes números de parasitas, avaliamos se existia alguma relação entre o número de células e a medida da turvação do meio na presença da droga.

Para isso, promastigotas de L. (L.) amazonensis $\left(3 \times 10^{7} / \mathrm{mL}\right)$ em $150 \mu \mathrm{L}$ de meio 199 foram incubados com diferentes concentrações de tamoxifeno $(5,10,15,20$ e $30 \mu \mathrm{M})$ em placas de 96 poços e avaliados após 24 e $48 \mathrm{~h}$ em diferentes comprimentos de onda (595, 620 e 595/ $690 \mathrm{~nm}$ ). A média dos valores de D.O. foram convertidos para porcentagem em relação ao controle e comparados com a média do número de células determinados por contagem em câmara de Neubauer, também convertidos para porcentagem. A atividade da droga foi avaliada em relação ao controle sem a droga considerado como 100\%. Através dos valores de D.O. observou-se que a turvação (barras azuis) foi semelhante entre os comprimentos de onda avaliados e os diferentes períodos de incubação, mas muito diferente da contagem de células (barras amarelas) (Figura 6). Na presença da droga os valores de D.O. foram maiores do que os dos 
controles sem a droga, ou seja, mesmo com os parasitas mortos o meio permanece turvo por pelo menos $48 \mathrm{~h}$ (Figura 6).

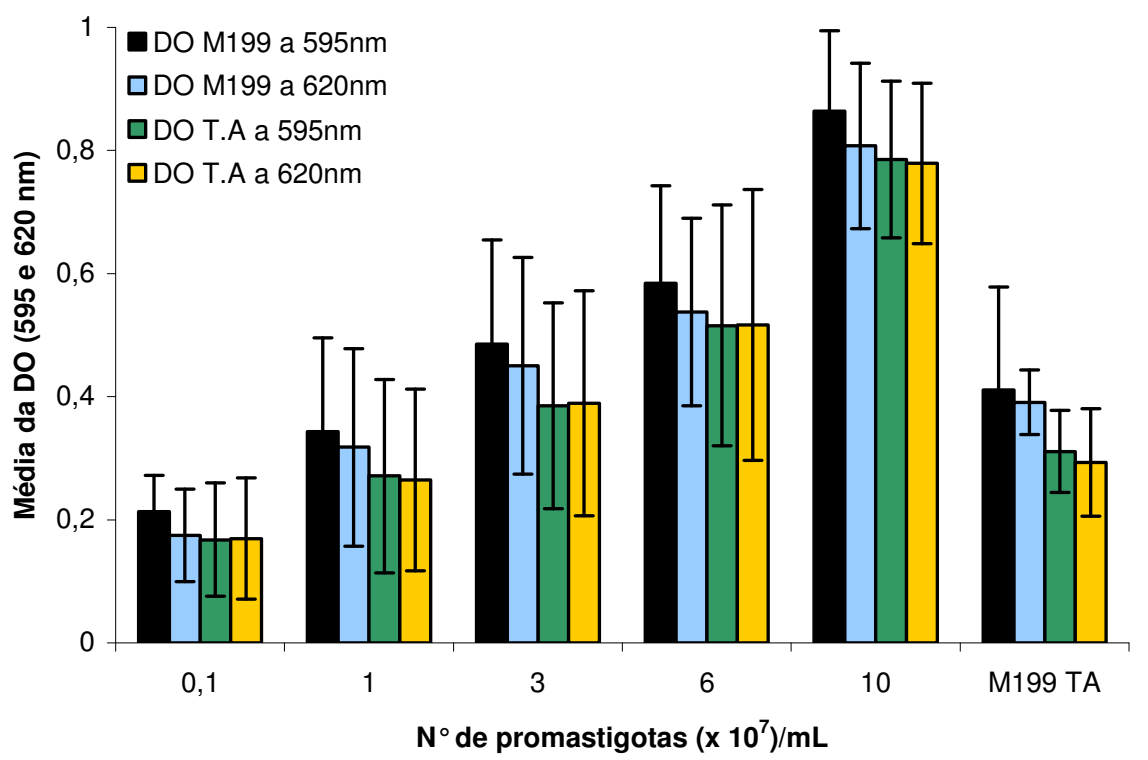

Figura 5: Turvação do meio 199 (M199) e tampão A (T.A) na presença de diferentes números de promastigotas ou ausência de promastigotas (M199 e TA) de L. (L.) major. Leitura de absorbância a 595 e $620 \mathrm{~nm}$.

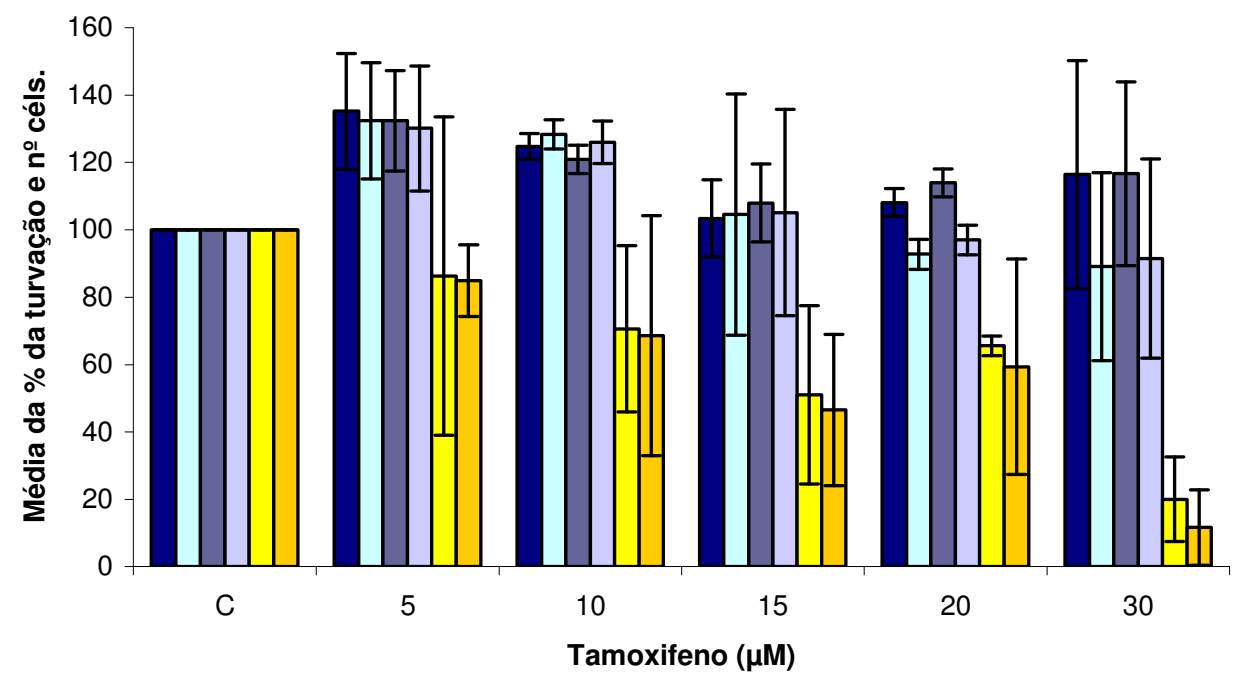

média da \% DO 595 nm turv. 24h

$\square$ média da \% DO 620 nm turv. 24h

$\square$ média da \% № céls. 24h $\square$ média da \% DO 595 nm turv. 48h $\square$ média da \% DO 620 nm turv. 48h $\square$ média da \% no céls. $48 \mathrm{~h}$

Figura 6: Média da porcentagem referente aos valores da turvação e contagem de células. Leitura de DO a 595, 620 e 595/690 nm após 24 e 48 h de incubação com diferentes concentrações de tamoxifeno $(5,10,15,20$ e $30 \mu \mathrm{M})$. 


\subsubsection{Modificação do teste de MTT}

\subsubsection{Teste de MTT e contagem de promastigotas em diferentes condições de cultura}

O teste de MTT para avaliação da viabilidade de promastigotas era utilizado no laboratório até o início deste trabalho como descrito por Moreira et al., (1996). Para avaliação de um grande número de amostras, esse método é trabalhoso e dispendioso. Por isso decidimos testar modificações do método de MTT para torná-lo mais rápido e barato. O método original envolve a incubação dos parasitas em meio de cultura por um período definido de tempo (24 ou 48 horas), seguido de centrifugação e lavagem dos parasitas em tampão A, para posterior incubação dos parasitas intactos ressuspensos em tampão A com MTT. Finalmente, as células foram lisadas com SDS.

Inicialmente, decidimos testar se seria possível manter os parasitas em tampão ou meio desprovido de indicadores coloridos durante o período de cultura, evitando assim a lavagem e troca de meio no decorrer do teste. Para isso, decidimos analisar o crescimento de promastigotas em diferentes meios através da contagem dos parasitas e leitura da DO após adição do MTT. Primeiramente, foram incubados $2 \times 10^{7}$ promastigotas $/ \mathrm{mL}$ de L. (L.) amazonensis a $25 \stackrel{\circ}{\circ} \mathrm{C}$ por $24 \mathrm{~h}$ em tampão $\mathrm{A}$, tampão $\mathrm{A}$ suplementado com SFB e meio de Grace suplementado com SFB. Após esse período, o número de células foi determinado por contagem em câmara de Neubauer. Observamos que em tampão $A$ e tampão $A$ suplementado com SFB o número de parasitas era o mesmo do inóculo inicial $\left(2 \times 10^{7}\right.$ promastigotas $\left./ \mathrm{mL}\right)$. Em meio de Grace suplementado com SFB havia mais parasitas do que o inóculo inicial (resultados não apresentados). Concluímos portanto que a incubação inicial em tampão $A$ não era adequada, já que não permitia a multiplicação dos parasitas.

A seguir testamos se a leitura da conversão do MTT pelo parasita viável podia ser adequadamente quantificado em meio de Grace. Assim, números progressivamente maiores de promastigotas $\left(1 \times 10^{6}, 1 \times 10^{7}, 5 \times 10^{7}\right.$ e $\left.1 \times 10^{8} / \mathrm{mL}\right)$ de L. (L.) amazonensis, foram incubados com MTT por 2 horas em tampão $A$ (controle da reação), em tampão $A$ suplementado com SFB e em meio de Grace com SFB. Após a lise, os valores de D.O. foram avaliados. Observamos que não ocorreram grandes mudanças na coloração em meio de Grace, mesmo na concentração mais alta, de $1 \times 10^{8}$ promastigotas $/ \mathrm{mL}$ (Figura 7). As D.O. medidas em tampão A e tampão A suplementado com SFB foram bastante 
próximas, indicando que o SFB presente no meio de Grace não era responsável pela ausência de leitura.

Anteriormente à adição de MTT, foi observada a morfologia dos promastigotas em microscópio óptico. As células cultivadas em meio de Grace suplementado com SFB estavam mais arredondadas, diferentes dos demais meios em que os promastigotas apresentavam-se mais afilados, parecidos com a forma promastigota convencional. Assim, concluímos que o meio de Grace não era adequado para a realização do teste de viabilidade por MTT.

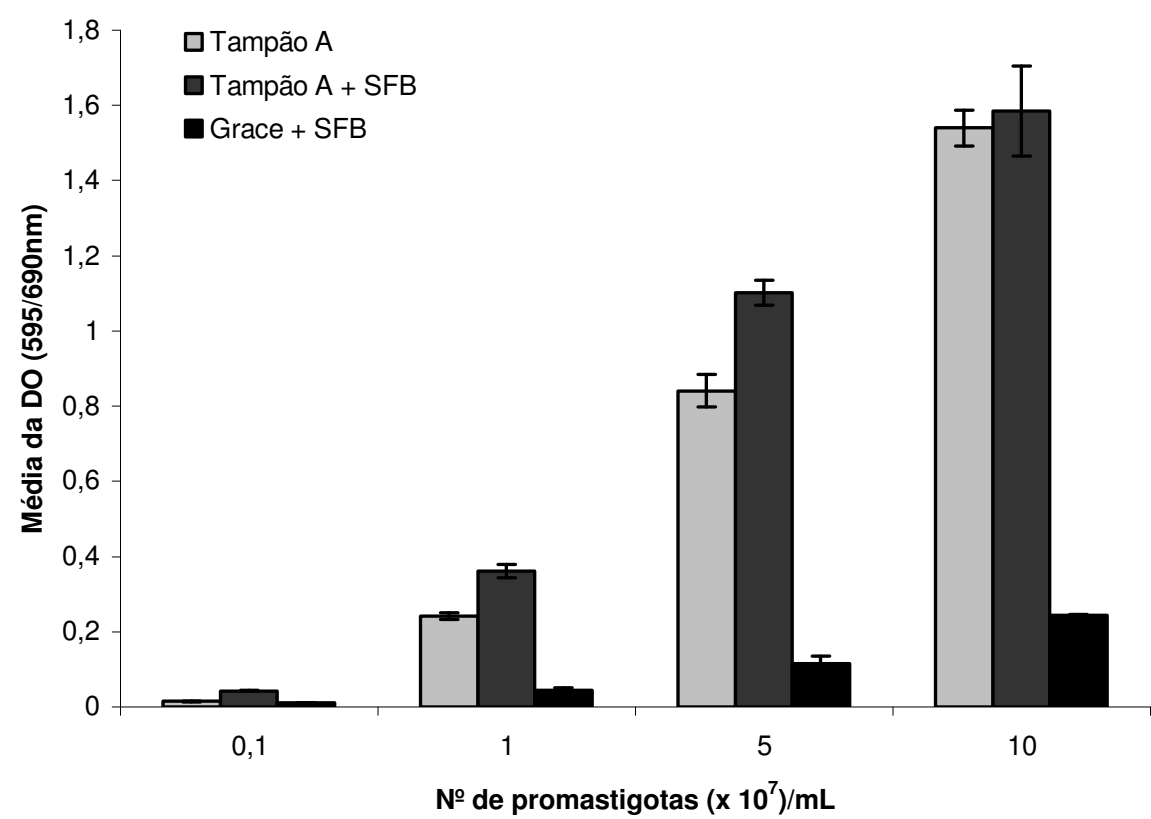

Figura 7: Relação entre o valor da D.O. e o número de parasitas após incubação a $25{ }^{\circ} \mathrm{C}$ por $24 \mathrm{~h}$ em tampão A, tampão A adicionado de SFB e meio Grace adicionado de SFB. 


\subsubsection{Microteste de MTT}

Após várias tentativas de testes de turvação, contagem de células e MTT em diferentes meios, decidimos testar modificações do método de MTT.

Assim, promastigotas de L. (L.) amazonensis $\left(3 \times 10^{7} / \mathrm{mL}\right)$ em $150 \mu \mathrm{L}$ de meio 199 foram incubados com diferentes concentrações de tamoxifeno $(5,10,15,20$ e $30 \mu \mathrm{M})$ em placas de 96 poços por 24 e 48h. A solução contendo MTT foi adicionada ao meio de cultura e, após 2 horas de incubação, as células foram lisadas com SDS. Todos os passos foram realizados na mesma microplaca, eliminando-se as etapas de lavagem e centrifugação. A leitura da D.O. foi realizada a 595/690 nm. A sobrevivência dos parasitas foi também avaliada em placas preparadas em paralelo, pela contagem do número de células em câmara de Neubauer. Os valores da D.O. foram convertidos para porcentagem do controle sem droga e comparados com a média do número de células também convertidos para porcentagem. A atividade da droga foi avaliada em relação ao controle sem a droga considerado como 100\%. O teste de MTT (barras azuis do gráfico) e o número de células (barras amarelas) foram semelhantes após 24 e 48h não apresentando diferenças nas leituras de absorbâncias nos comprimentos de onda avaliados (Figura 8).

O microteste de MTT modificado mostrou-se eficaz para avaliação da sensibilidade in vitro de promastigotas de Leishmania. Nesse microteste utiliza-se somente placa de 96 poços de fundo plano e os resultados são analisados após 24 horas de incubação com a droga. 


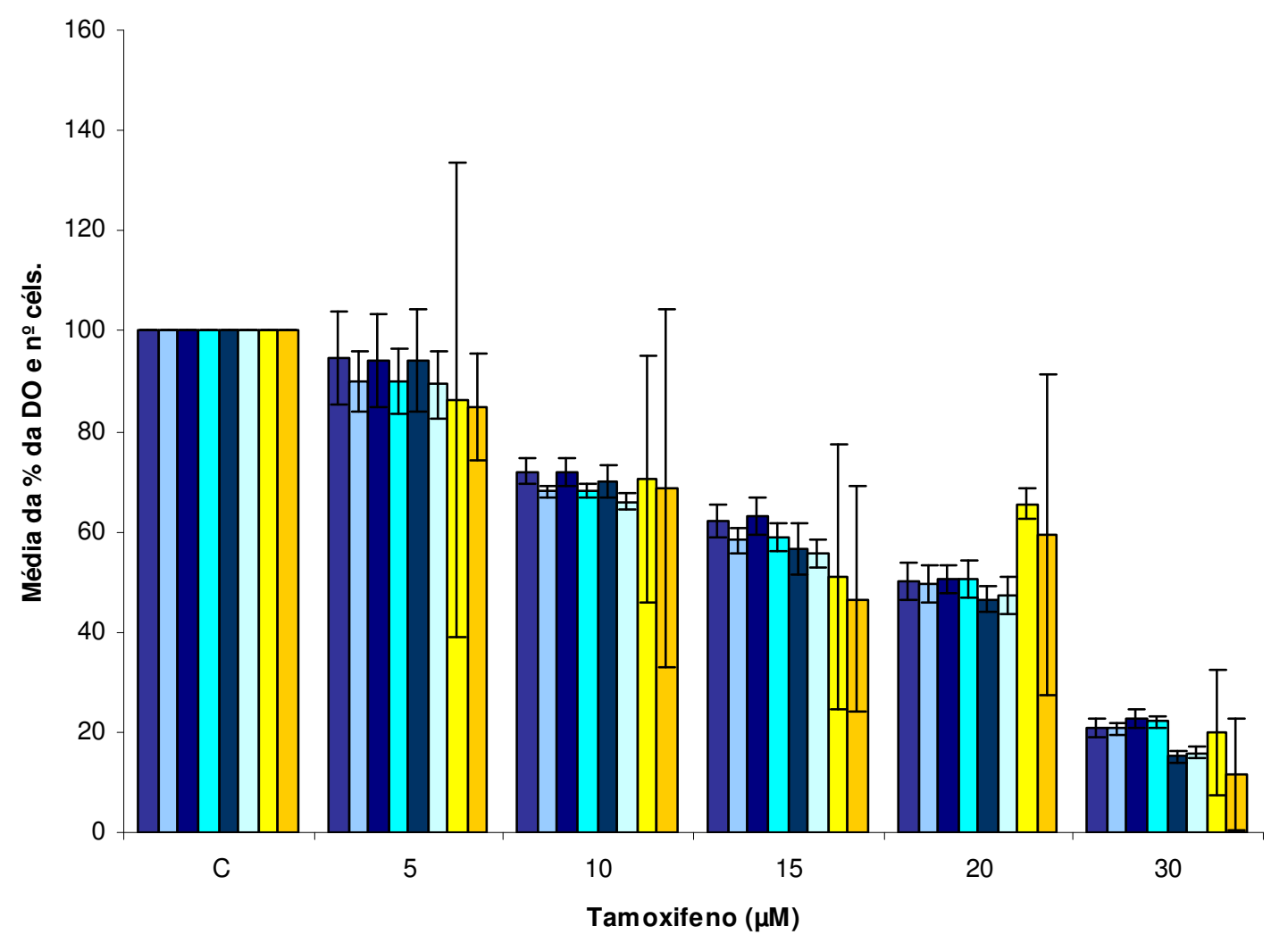
- $595 \mathrm{~nm} 24 \mathrm{~h}-\mathrm{MTT}$
- $620 \mathrm{~nm} 24 \mathrm{~h}-\mathrm{MTT}$
$\square 595$ e $690 \mathrm{~nm} 24 \mathrm{~h}-\mathrm{MTT}$
$\square \mathrm{n}^{\circ}$ céls. $24 \mathrm{~h}$
$595 \mathrm{~nm} 48 \mathrm{~h}-\mathrm{MTT}$
$620 \mathrm{~nm} 48 \mathrm{~h}-\mathrm{MTT}$
595 e $690 \mathrm{~nm} 48 \mathrm{~h}-\mathrm{MTT}$
$\square \mathrm{n}^{\circ}$ céls. $48 \mathrm{~h}$

Figura 8: Comparação entre o microteste de MTT e a contagem de células para avaliação da viabilidade de promastigotas incubados com tamoxifeno. Média da porcentagem de viabilidade referente aos valores da D.O. (MTT) e contagem de células. Leitura da D.O. a 595, 620 e 595/690 nm após 24 e 48h de incubação com diferentes concentrações de tamoxifeno. 


\subsection{Atividade do tamoxifeno e anfotericina B contra promastigotas de Leishmania in vitro através do microteste de MTT modificado}

Para avaliação da sensibilidade de isolados de Leishmania às drogas anfotericina $B$ e tamoxifeno, foram utilizadas as formas promastigotas dos isolados obtidos dos pacientes e das cepas referência de L. (V.) braziliensis MHOM/BR/1975/M2903, L. (L) amazonensis MHOM/BR/1973/M2269 e L. (L.) major MHOM/LL/81/Friedlin.

Como observamos variação da atividade da droga (avaliada por valores de $\mathrm{Cl}_{50}$ ) em testes de MTT realizados em dias diferentes com promastigotas de $L$. (V.) braziliensis (Figura 9), os testes com isolados foram sempre realizados em paralelo com a linhagem tipo. A atividade das drogas foi avaliada através da $\mathrm{Cl}_{50}$, ou seja, a concentração de droga capaz de inibir $50 \%$ da viabilidade celular, $\mathrm{Cl}_{90}$ (inibição de $90 \%$ da viabilidade celular) e razão de resistência (razão entre o valor de $\mathrm{Cl}_{50}$ do isolado e da cepa referência).

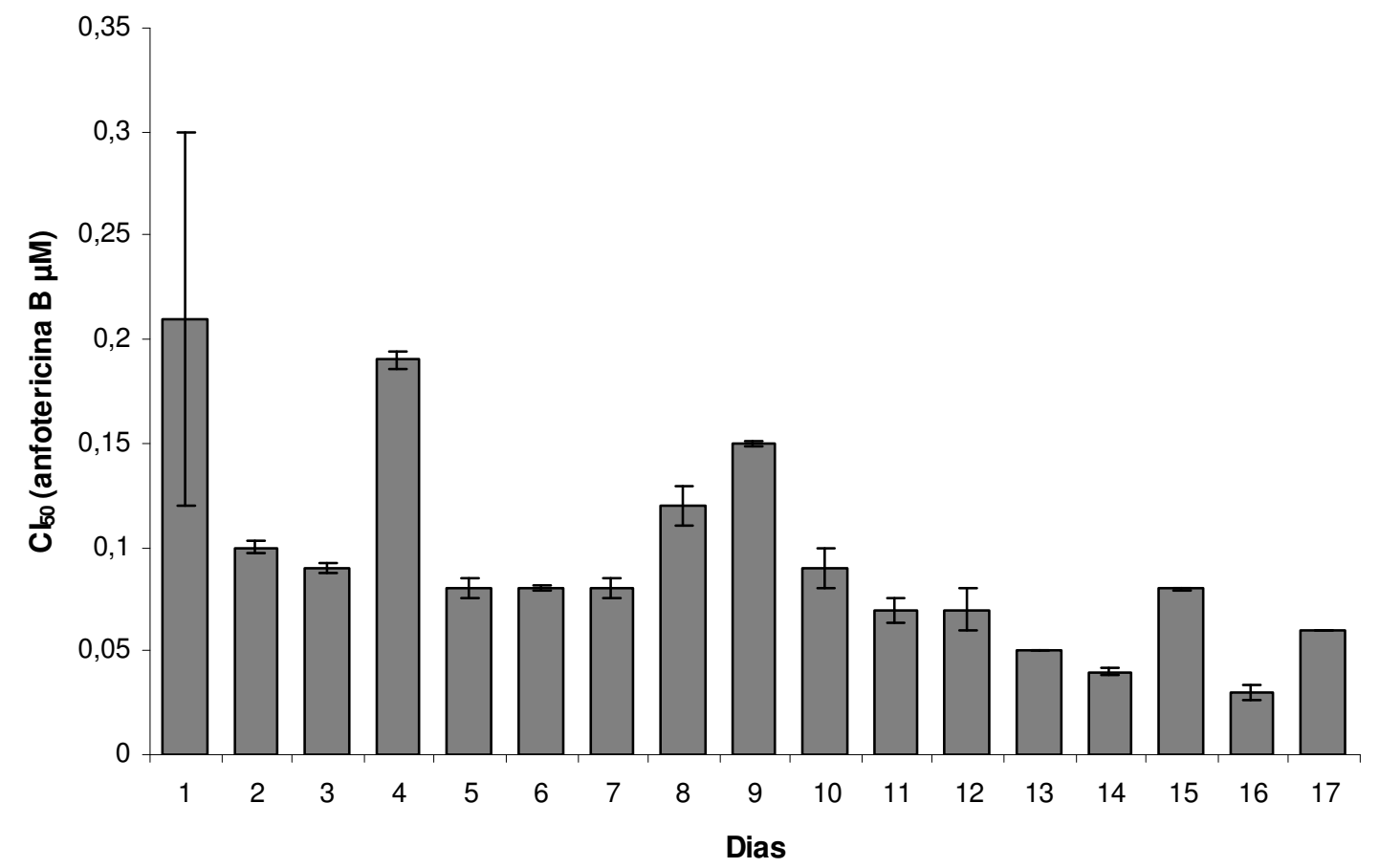

Figura 9: Variação do valor de $\mathrm{Cl}_{50}$ obtido a partir do microteste de MTT realizado em dias diferentes com promastigotas de $L$. (V.) braziliensis. Em cada experimento, as amostras foram analisadas em triplicata e são mostrados os valores das médias de $\mathrm{Cl}_{50}$ e desvio padrão. 
Como mostrado na Tabela 3, os valores de $\mathrm{Cl}_{50}$ determinados para anfotericina $\mathrm{B}$ variaram entre 0,04 $\pm 0,004 \mu \mathrm{M}$ para o isolado de $L$. (V.) braziliensis (PPS/06/BA) e 0,73 $\pm 0,05 \mu \mathrm{M}$ para o isolado de L. (L.) major-like (VBL/01/PA). Os valores de $\mathrm{Cl}_{90}$ variaram entre 0,09 e 1,83 $\mu \mathrm{M}$ de anfotericina $B$ para o isolado de $L$. (V.) braziliensis TMB/06/GO e para a cepa referência de $L$. (L.) major MHOM/IL/81/Friedlin, respectivamente. O menor valor da $\mathrm{RR}$ foi identificado para $\mathrm{TMB} / 06 / \mathrm{GO}$, igual a $0,66 \pm 0,01$, e o maior para VBL/01/PA $(2,77 \pm 0,23)$ (Tabela 3).

A sensibilidade dos isolados à anfotericina $B$ foi semelhante, sendo que somente um isolado de $L$. (L.) major-like apresentou menor sensibilidade a essa droga.

Tabela 3: Atividade in vitro de anfotericina B contra promastigotas de Leishmania.

\section{Promastigotas}

\begin{tabular}{|c|c|c|c|c|}
\hline Espécie & Paciente/ano/local & $\begin{array}{c}\mathrm{IC}_{50} \pm \mathrm{DP} \\
\text { Anf. B }(\mu \mathrm{M})\end{array}$ & $\begin{array}{c}\text { IC }_{90} \\
\text { Anf. } B(\mu \mathrm{M})\end{array}$ & $\begin{array}{l}\text { Razão de } \\
\text { resistência }\end{array}$ \\
\hline L. (V.) braziliensis & MHOM/BR/75/M2903 & $0,09 \pm 0,049$ & 0,38 & - \\
\hline L. (V.) braziliensis & BA788/01 & $0,12 \pm 0,014$ & 0,30 & $1,50 \pm 0,23$ \\
\hline L. (V.) braziliensis & $\mathrm{BES} / 06 / \mathrm{GO}$ & $0,05 \pm 0,001$ & 0,39 & $0,78 \pm 0,04$ \\
\hline L. (V.) braziliensis & EFSF/06/GO & $0,06 \pm 0,005$ & 0,70 & $0,85 \pm 0,05$ \\
\hline L. (V.) braziliensis & GDL/06/GO & $0,05 \pm 0,001$ & 0,18 & $0,91 \pm 0,08$ \\
\hline L. (V.) braziliensis & HPV/06/TO & $0,10 \pm 0,004$ & 0,18 & $1,63 \pm 0,07$ \\
\hline L. (V.) braziliensis & IMG/03/GO & $0,07 \pm 0,003$ & 0,25 & $1,46 \pm 0,22$ \\
\hline L. (V.) braziliensis & PPS/06/BA & $0,04 \pm 0,004$ & 0,47 & $0,70 \pm 0,13$ \\
\hline L. (V.) braziliensis & RPL/05/GF & $0,06 \pm 0,003$ & 0,12 & $0,86 \pm 0,03$ \\
\hline L. (V.) braziliensis & TMB/06/GO & $0,05 \pm 0,001$ & 0,09 & $0,66 \pm 0,01$ \\
\hline L. (V.) braziliensis & UAF/06/TO & $0,07 \pm 0,001$ & 0,13 & $1,06 \pm 0,05$ \\
\hline L. (V.) braziliensis & WSS/05/GO & $0,07 \pm 0,005$ & 0,13 & $0,79 \pm 0,04$ \\
\hline L. (L.) amazonensis & MHOM/BR/73/M2269 & $0,15 \pm 0,040$ & 0,31 & - \\
\hline L. (L.) amazonensis & EGS/04/GO & $0,09 \pm 0,006$ & 0,27 & $1,04 \pm 0,11$ \\
\hline L. (L.) amazonensis & JRS/01/GO & $0,06 \pm 0,001$ & 0,23 & $0,72 \pm 0,01$ \\
\hline L. (L.) amazonensis & JSC/06/PA & $0,07 \pm 0,001$ & 0,17 & $0,77 \pm 0,01$ \\
\hline L. (L.) major & MHOM/IL/81/Friedlin & $0,35 \pm 0,050$ & 1,83 & - \\
\hline L. (L.) major-like & $\mathrm{MAB} / 03 / \mathrm{PA}$ & $0,18 \pm 0,011$ & 0,65 & $2,00 \pm 0,24$ \\
\hline L. (L.) major-like & VBL/01/PA & $0,73 \pm 0,050$ & 1,46 & $2,77 \pm 0,23$ \\
\hline
\end{tabular}


Os valores de $\mathrm{Cl}_{50}$ determinados para tamoxifeno variaram entre 6,0 \pm 0,93 $\mu \mathrm{M}$ para o isolado de L. (V.) braziliensis (BES/06/GO) e 14,8 $\pm 0,99 \mu \mathrm{M}$ para o isolado de $L$. (L.) amazonensis (EGS/04/GO). Os valores de $\mathrm{Cl}_{90}$ variaram entre 12,2 e 28,7 $\mu \mathrm{M}$ de tamoxifeno para o isolado de $L$. (V.) braziliensis BES/06/GO e a cepa referência de $L$. (L.) major MHOM/LL/81/Friedlin, respectivamente. Para BES/06/GO o valor da RR foi igual a $0,68 \pm 0,16$ e para VBL/01/PA foi igual a 1,31 $\pm 0,56$ (Tabela 4).

Tabela 4: Atividade in vitro de tamoxifeno contra promastigotas de Leishmania.

\section{Promastigotas}

\begin{tabular}{lcccc}
\hline Espécie & Paciente/ano/local & $\begin{array}{c}\text { IC }_{50} \pm \text { DP } \\
\text { TAM }(\mu \mathrm{M})\end{array}$ & $\begin{array}{c}\text { IC }_{90} \\
\text { TAM }(\mu \mathrm{M})\end{array}$ & $\begin{array}{c}\text { Razão de } \\
\text { resistência }\end{array}$ \\
\hline L. $(V$.$) braziliensis$ & MHOM/BR/75/M2903 & $10,8 \pm 3,7$ & 19,7 & - \\
L. (V.) braziliensis & BA788/01 & $13,4 \pm 0,28$ & 24,8 & $1,11 \pm 0,14$ \\
L. (V.) braziliensis & BES/06/GO & $6,0 \pm 0,93$ & 12,2 & $0,68 \pm 0,16$ \\
L. (V.) braziliensis & EFSF/06/GO & $9,3 \pm 0,80$ & 18,3 & $0,96 \pm 0,08$ \\
L. (V.) braziliensis & GDL/06/GO & $8,9 \pm 1,05$ & 14,0 & $0,89 \pm 0,08$ \\
L. (V.) braziliensis & HPV/06/TO & $10,9 \pm 0,41$ & 16,9 & $0,73 \pm 0,02$ \\
L. (V.) braziliensis & IMG/03/GO & $9,2 \pm 0,36$ & 14,8 & $0,80 \pm 0,07$ \\
L. (V.) braziliensis & PPS/06/BA & $9,1 \pm 0,95$ & 21,5 & $0,69 \pm 0,07$ \\
L. (V.) braziliensis & RPL/05/GF & $8,4 \pm 0,41$ & 15,6 & $0,99 \pm 0,06$ \\
L. (V.) braziliensis & TMB/06/GO & $8,4 \pm 0,20$ & 14,1 & $1,06 \pm 0,05$ \\
L. (V.) braziliensis & UAF/06/TO & $9,1 \pm 0,05$ & 14,6 & $1,12 \pm 0,04$ \\
L. (V.) braziliensis & WSS/05/GO & $6,5 \pm 0,57$ & 12,4 & $0,87 \pm 0,05$ \\
L. (L.) amazonensis & MHOM/BR/73/M2269 & $11,4 \pm 2,53$ & 21,9 & - \\
L. (L.) amazonensis & EGS/04/GO & $14,8 \pm 0,99$ & 22,7 & $1,25 \pm 0,46$ \\
L. (L.) amazonensis & JRS/01/GO & $9,0 \pm 2,93$ & 24,6 & $0,73 \pm 0,43$ \\
L. (L.) amazonensis & JSC/06/PA & $7,2 \pm 0,47$ & 14,8 & $0,81 \pm 0,63$ \\
L. (L.) major & MHOM/IL/81/Friedlin & $7,5 \pm 1,60$ & 28,7 & - \\
L. (L.) major-like & MAB/03/PA & $7,2 \pm 0,04$ & 13,2 & $1,18 \pm 0,03$ \\
L. (L.) major-like & VBL/01/PA & $9,8 \pm 010$ & 14,4 & $1,31 \pm 0,56$ \\
\hline
\end{tabular}




\subsection{Suscetibilidade de promastigotas de Leishmania ao antimônio in vitro}

Embora existam vários relatos na literatura sobre a baixa sensibilidade de promastigotas aos antimoniais, alguns dos trabalhos que comparam a sensibilidade de isolados a esses fármacos utilizam essa forma do ciclo, que permitiria a comparação entre diferentes parasitas. Assim, utilizamos inicialmente promastigotas de L. (V.) braziliensis nos testes de sensibilidade ao Glucantime ${ }^{\circledR}$.

A sensibilidade de promastigotas de L. (V.) braziliensis ao Glucantime $^{\circledR} \mathrm{e}$ antimoniato de meglumina foi avaliada inicialmente pelo método de MTT. Promastigotas $\left(5 \times 10^{6} / 150 \mu \mathrm{L}\right)$ de terceiro ou quarto dia foram incubados por 24 horas na presença de 2,7, 10,8 e $32,4 \mathrm{mg} / \mathrm{mL}$ de antimônio pentavalente $\left(\mathrm{Sb}^{v}\right)$, lembrando que $1,5 \mathrm{~g}$ de antimoniato de meglumine equivale a $0,405 \mathrm{~g}$ de antimônio pentavalente (MINISTÉRIO DA SAÚDE, 2007). A dose máxima de antimônio utilizada $(32,4 \mathrm{mg} / \mathrm{mL})$ inibiu muito pouco o crescimento de promastigotas de $L$. (V.) braziliensis (Figura 10). Foram testados vários lotes de Glucantime ${ }^{\circledR}$ e todos apresentaram o mesmo comportamento (Figura 10).

Lote $1 \square$ Lote $2 \square$ Lote $3 \quad \square$ Lote $4 \quad \square$ Lote $5 \square$ Antimoniato de meglumina

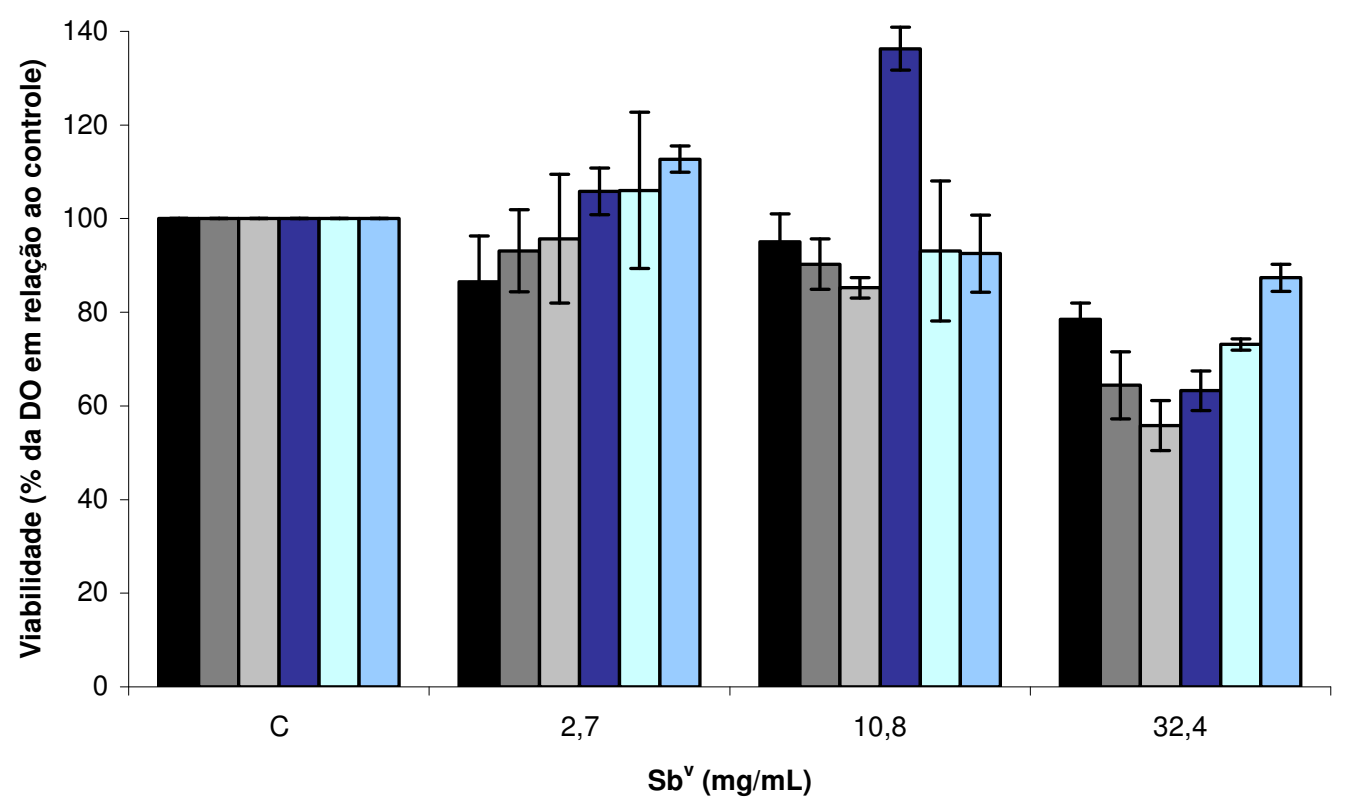

Figura 10: Atividade de diferentes lotes de Glucantime ${ }^{\circledR}$ e antimoniato de meglumina contra promastigotas de L. (V.) braziliensis através do método de MTT. Os resultados mostram a viabilidade em relação às culturas não tratadas com a droga. $\mathrm{Sb}^{\mathrm{v}}=$ antimônio pentavalente. 
Testamos então tempos de incubação mais longos, analisando a contagem de parasitas vivos após 24, 48, 72 e 120 h de incubação com a droga em placas de 24 poços. Promastigotas $\left(5 \times 10^{6}\right)$ de L. (V.) braziliensis e L. (L.) amazonensis foram incubados na presença de 16,2 e $32,4 \mathrm{mg} / \mathrm{mL}$ de antimônio e $30 \mu \mathrm{M}$ de tamoxifeno, utilizado como controle positivo. Após 24 horas observou-se redução do número de parasitas em todas as doses de $\mathrm{Sb}^{v}$ testadas, enquanto na presença de tamoxifeno já não havia mais parasitas vivos. Em tempos longos de incubação, observamos correlação entre a dose de $\mathrm{Sb}^{\mathrm{v}}$ e a atividade, porém, mesmo com doses muito altas, somente observamos morte de $100 \%$ dos parasitas em culturas de L. (V.) braziliensis incubadas com 32,4 mg/mL e após 120h (Figura 11 A e B).

Concluímos que essa forma de avaliar a sensibilidade ao antimônio não era adequada já que os testes eram longos e trabalhosos, além de existir a crítica de que o antimônio pentavalente teria que ser convertido pelo macrófago a antimônio trivalente para ter atividade contra o parasita. 

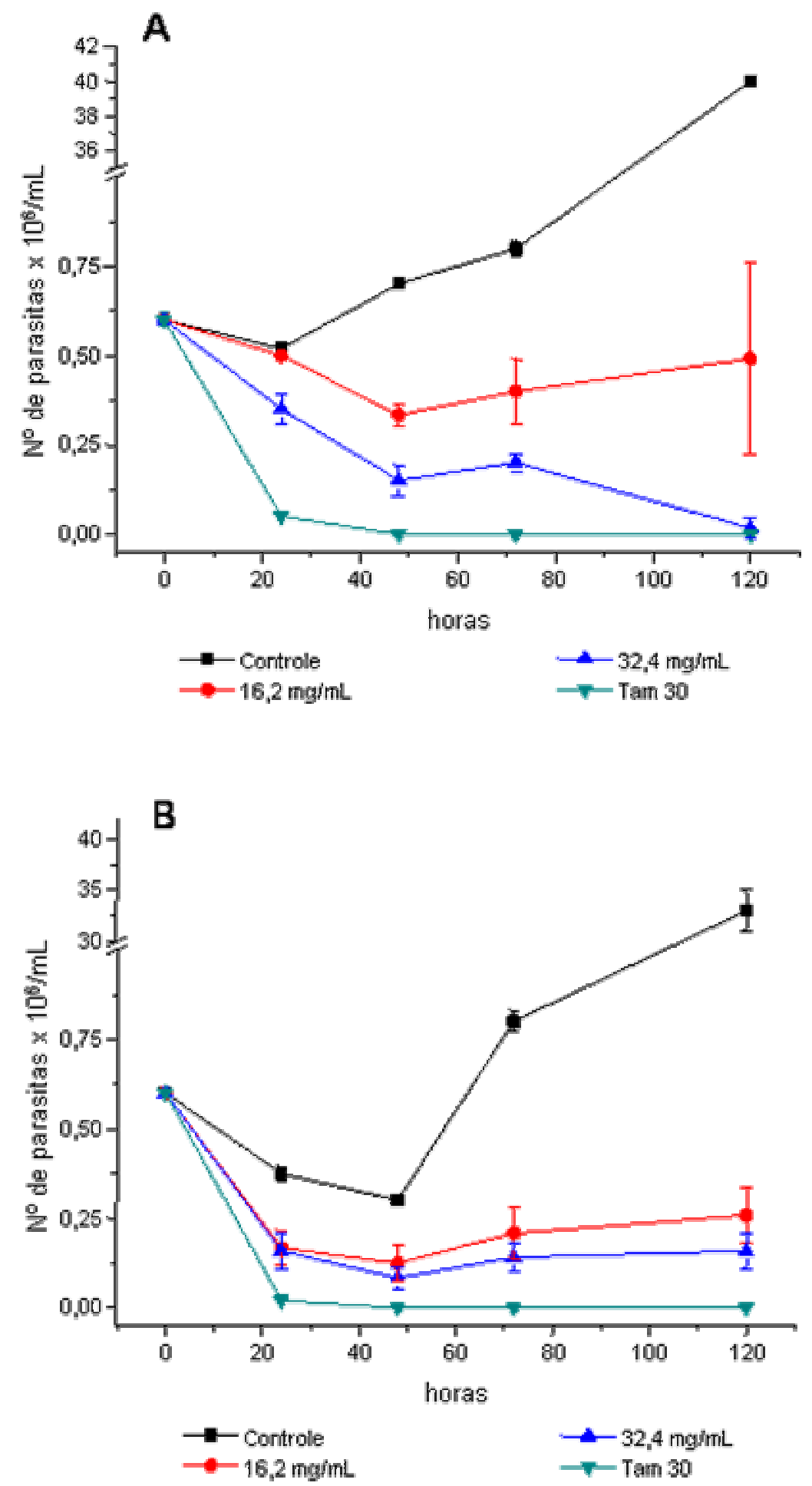

Figura 11: Curva de crescimento de promastigotas de $L$. (V.) braziliensis (A) e $L$. (L.) amazonensis (B) na presença de $\mathrm{Sb}^{v}(16,2$ e $32,4 \mathrm{mg} / \mathrm{mL})$ e $30 \mu \mathrm{M}$ de tamoxifeno (Tam 30). Parasitas $\left(5 \times 10^{6}\right)$ foram incubados por $24,48,72$ e 120 horas e contados em câmara de Neubauer. 


\subsection{Infecção de diferentes tipos de macrófagos por L. (V.) braziliensis}

Além dos promastigotas apresentarem baixa sensibilidade ao antimônio pentavalente, para avaliar a sensibilidade dos amastigotas existe também o problema de infecção in vitro por $L$. (V.) braziliensis. Não havia na literatura descrições de modelos de macrófagos para infecção com essa espécie. Por isso, avaliamos a infectividade de quatro tipos diferentes de macrófagos (J774.A1, THP-1, macrófagos de peritônio e macrófagos de medula) por $L$. (V.) braziliensis. Foram testadas diferentes proporções (5, 10 e 15 parasitas por macrófago) em diferentes tempos de incubação para infecção (3 e 24 h). Para infecção de macrófagos J774.A1 foi utilizada tanto a cepa referência de $L$. (V.) braziliensis quanto de L. (L.) amazonensis. A maior taxa de infecção para esses macrófagos foi de 18,6\% com L. (V.) braziliensis (Figura 12 A) e 8,3\% com L. (L.) amazonensis (dados não apresentados).

Para infecção de macrófago de peritônio foram utilizados $L$. (V.) braziliensis MHOM/BR/1975/M2903 e o isolado HPV/06/TO de L. (V.) braziliensis. Como os macrófagos de linhagem J774.A1, os macrófagos de peritônio também tiveram um índice baixo de infecção (Figura 12 A e B). Os resultados foram os mesmos para as duas cepas analisadas (L. (V.) braziliensis e o isolado HPV/06/TO) (dados não apresentados).

Macrófagos de linhagem leucêmica humana THP-1 também foram testados nas mesmas condições descritas acima para macrófagos J774.A1 e macrófagos de peritônio. Com os macrófagos THP-1 também não se obteve infecção apreciável (Figura 12 A e B).

Depois de testados os três tipos de macrófagos sem que se obtivesse resultados satisfatórios de infecção, decidimos infectar macrófagos extraídos de medula de camundongos BALB/c.

Os testes com macrófagos de medula foram realizados nas mesmas condições utilizadas para os macrófagos J774.A1, THP-1 e de peritônio. Nas proporções de 5, 10 e 15 parasitas por macrófago durante 3 horas de infecção com L. (V.) braziliensis, obtevese taxas de 59,76 e $84 \%$ de infecção, respectivamente.

Como mostrado na figura 12 A e B, a taxa de infecção de macrófagos de medula com L. (V.) braziliensis foi muito maior do que para os demais macrófagos, além desse macrófago apresentar citoplasma expandido facilitando a observação e contagem dos amastigotas. Uma vantagem adicional da utilização dessas células é o maior rendimento em comparação com macrófagos de peritônio murino. 


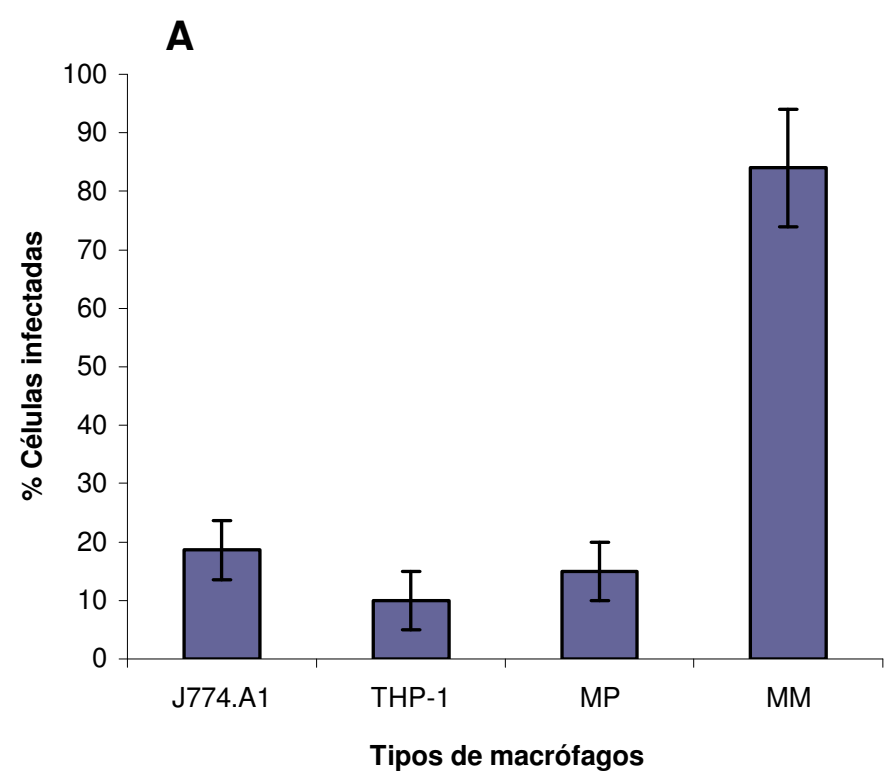

B

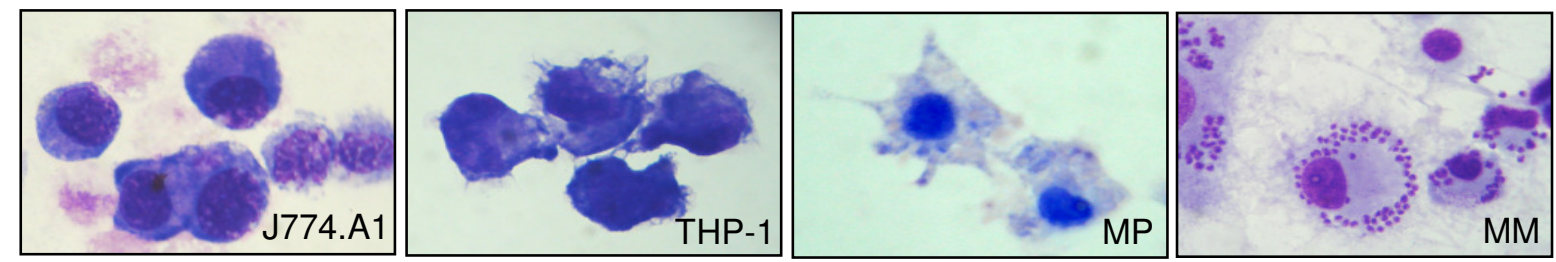

Figura 12: Infectividade de $L$. (V.) braziliensis para diferentes tipos de macrófagos. Os ensaios foram realizados com proporção de 15 parasitas/macrófago durante $3 \mathrm{~h}$ de infecção. J774.A1 e THP-1, macrófagos de linhagem; MP, macrófago de peritônio e MM, macrófago de medula. (A) porcentagem de células infectadas e (B) morfologia de células infectadas (1000x). 


\subsection{Ensaios de citotoxicidade}

A toxicidade do Glucantime ${ }^{\circledR}$ e tamoxifeno foi avaliada em macrófagos de medula através da viabilidade celular, medida por MTT. Macrófagos foram incubados por seis dias com diferentes concentrações de tamoxifeno $(10,15$ e $20 \mu \mathrm{M})$ e Glucantime $^{\circledR}(135$, 405 e $810 \mu \mathrm{g} / \mathrm{mL}$ de $\mathrm{Sb}^{\mathrm{v}}$ ). A citotoxicidade foi avaliada em relação ao controle sem a droga. $\mathrm{A} I \mathrm{C}_{50}$ de tamoxifeno para macrófagos de medula foi maior do que $20 \mu \mathrm{M}$ e de antimônio maior do que $810 \mu \mathrm{g} / \mathrm{mL}$ (Figura 13 A e B).

A

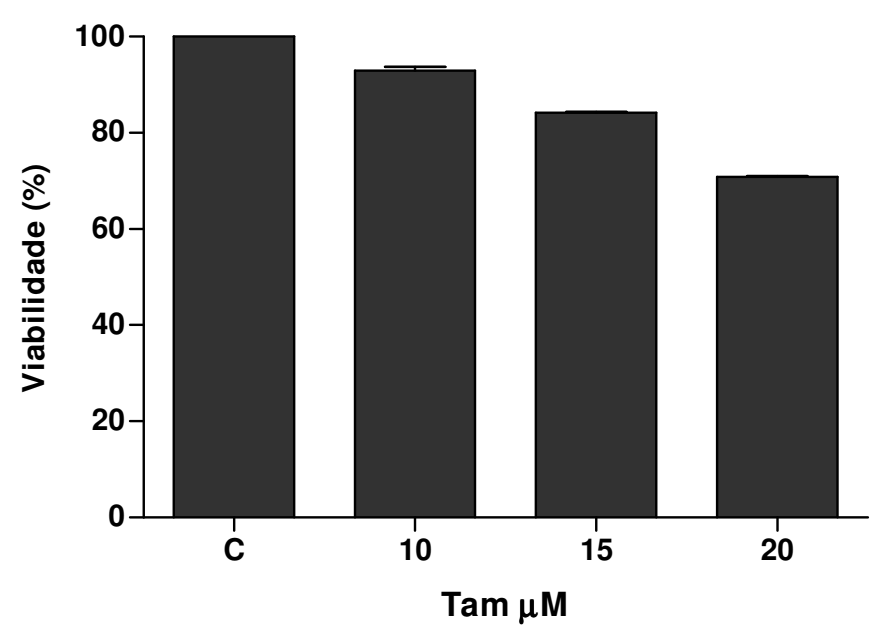

B

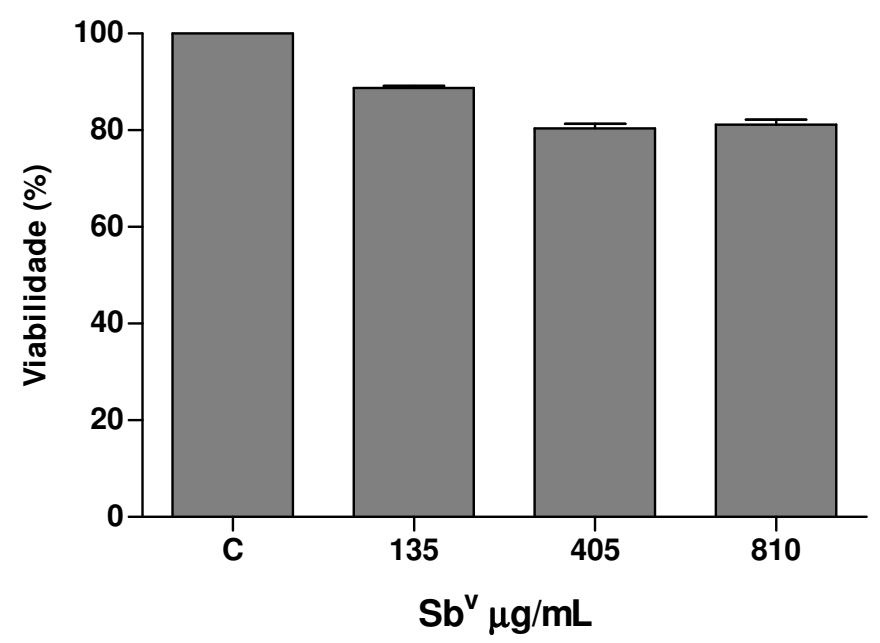

Figura 13: Toxicidade de tamoxifeno $(A)$ e Glucantime ${ }^{\circledR}$ (B) para macrófagos de medula de camundongo BALB/c. Macrófagos de medula foram incubados na presença de tamoxifeno (Tam) e Glucantime ${ }^{\circledR}$ por 6 dias a $33^{\circ} \mathrm{C}$ e $5 \%$ de $\mathrm{CO}_{2}$ e a viabilidade foi avaliada através do teste de MTT. C, controle sem a droga. 


\subsection{Sensibilidade de amastigotas de Leishmania in vitro a antimônio pentavalente}

Macrófagos de medula infectados com as cepas referência ou com os diferentes isolados foram tratados com Glucantime ${ }^{\circledR}$ utilizando doses de 13,5, 40,5, 135 e 405 $\mu \mathrm{g} / \mathrm{mL}$ de $\mathrm{Sb}^{v}$ durante 5 dias. Em infecções com a cepa referência MHOM/BR/75/M2903 foi testada a atividade de diferentes lotes de Glucantime ${ }^{\circledR}$ não sendo observada diferença de atividade da droga entre os lotes testados (resultados não apresentados).

A taxa de infecção para os diferentes isolados foi avaliada determinando-se a porcentagem de macrófagos infectados no controle não tratado. A taxa de infecção variou entre 20 e $85 \%$ para os isolados de L. (V.) braziliensis, entre 50 e $100 \%$ para os isolados de L. (L.) amazonensis e de 58 e 68\% para os isolados de L. (L.) major-like (Anexo A).

Além da porcentagem de infecção, foi analisado também o número de amastigotas por macrófago. Na infecção de isolados de L. (V.) braziliensis encontrou-se em média 5 amastigotas por macrófago no controle sem a droga. Na infecção dos isolados de $L$. (L.) amazonensis e $L$. (L.) major-like encontrou-se em média 11 e 5 amastigotas por macrófago, respectivamente. Na presença da droga o número de parasitas por macrófago diminuiu com o aumento da concentração de antimônio (Anexo A).

Em todos os experimentos foi incluída a cepa referência testada em paralelo com os isolados. Os experimentos para cada isolado foram feitos em triplicata e repetidos pelo menos 2 vezes. Na Figura 14 mostramos o resultado da média de 5 experimentos para a cepa referência.

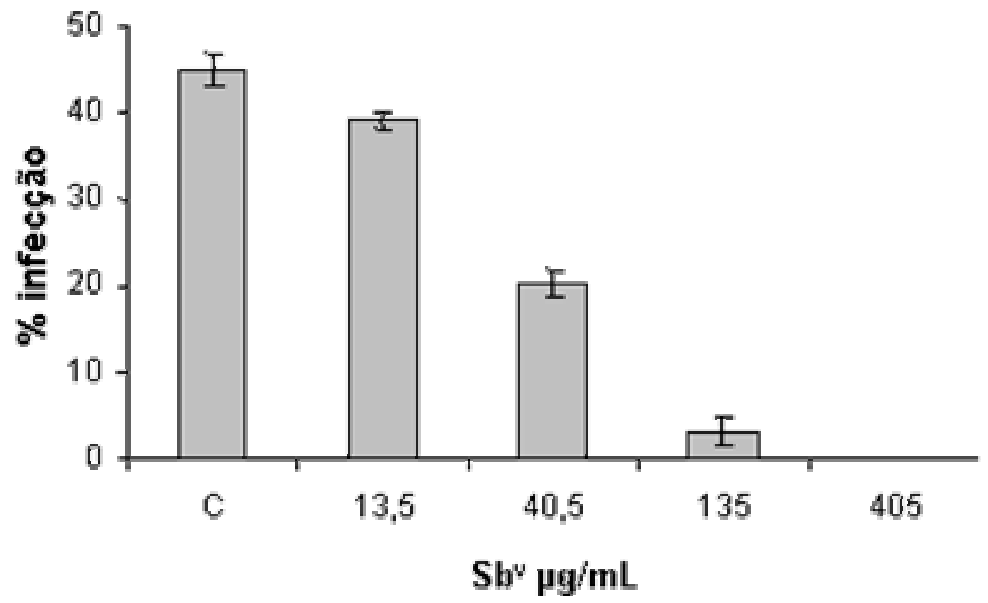

Figura 14: Atividade de antimônio $\left(\mathrm{Sb}^{v}\right)$ contra amastigotas de Leishmania (V.) braziliensis $\mathrm{MHOM} / \mathrm{BR} / 75 / \mathrm{M} 2903$. Infecção de macrófagos de medula de camundongo BALB/C tratados por 5 dias. 
Os testes de sensibilidade dos isolados ao Glucantime ${ }^{\circledR}$ foram realizados com macrófagos obtidos de medula óssea de camundongos BALB/c infectados com promastigotas. Doses de $\mathrm{Sb}^{v}(13,5,40,5,135$ e $405 \mu \mathrm{g} / \mathrm{mL})$ foram adicionadas por 6 dias após $3 \mathrm{~h}$ de incubação dos promastigotas com os macrófagos. Os valores de $\mathrm{Cl}_{50}$ variaram entre 18,5 $\pm 4,2 \mu \mathrm{g} / \mathrm{mL}$ para o isolado de $L$. (V.) braziliensis PPS/06/BA e 146,0 $\pm 5,0 \mu \mathrm{g} / \mathrm{mL}$ para 0 isolado de L. (L.) amazonensis JSC/06/PA. Os valores de $\mathrm{Cl}_{90}$ variaram entre $65,6 \mu \mathrm{g} / \mathrm{mL}$ para o isolado de $L$. (V.) braziliensis TMB/06/GO e 955,45 $\mu \mathrm{g} / \mathrm{mL}$ para o isolado de $L$. (L.) major-like MAB/03/PA. O maior valor de RR obtido foi de 2,67 $\pm 0,35$ para $L$. (L.) amazonensis (JSC/06/PA) e o menor valor de 0,5 $\pm 0,23$ para $L$. (V.) braziliensis (PPS/06/BA). A sensibilidade a antimônio variou até 8 vezes entre 0 menor e o maior valor de $\mathrm{Cl}_{50}$ e até 14 e 5 vezes entre o menor e o maior valor de $\mathrm{Cl}_{90} \mathrm{e}$ $R R$, respectivamente (Tabela 5). Os isolados de $L$. (V.) braziliensis apresentaram maior sensibilidade ao antimônio do que os isolados tipados como $L$. (L.) amazonensis e $L$. (L.) major-like.

Tabela 5: Atividade in vitro de antimônio pentavalente contra amastigotas de Leishmania.

\section{Amastigotas}

\begin{tabular}{|c|c|c|c|c|}
\hline Espécie & Paciente/ano/local & $\begin{array}{l}I_{C_{50}} \pm \mathrm{DP} \\
\mathrm{Sb}^{\mathrm{v}} \mu \mathrm{g} / \mathrm{mL}\end{array}$ & $\begin{array}{c}\mathrm{IC}_{90} \\
\mathrm{Sb}^{\mathrm{v}} \mu \mathrm{g} / \mathrm{mL}\end{array}$ & $\begin{array}{c}\text { Razão de } \\
\text { resistência }\end{array}$ \\
\hline L. (V.) braziliensis & MHOM/BR/75/M2903 & $34,1 \pm 5,0$ & 119,0 & \\
\hline L. (V.) braziliensis & BA788/01 & $37,2 \pm 8,3$ & 177,5 & $1,1 \pm 0,45$ \\
\hline L. (V.) braziliensis & $\mathrm{BES} / 06 / \mathrm{GO}$ & $52,4 \pm 5,3$ & 203,3 & $1,5 \pm 0,26$ \\
\hline L. (V.) braziliensis & EFSF/06/GO & $55,0 \pm 12$ & 150,2 & $1,6 \pm 0,67$ \\
\hline L. (V.) braziliensis & GDL/06/GO & $31,1 \pm 1,5$ & 96,0 & $0,9 \pm 0,06$ \\
\hline L. (V.) braziliensis & HPV/06/TO & $58,0 \pm 14$ & 299,7 & $1,7 \pm 0,76$ \\
\hline L. (V.) braziliensis & IMG/03/GO & $58,8 \pm 5,4$ & 175,8 & $1,7 \pm 0,27$ \\
\hline L. (V.) braziliensis & PPS/06/BA & $18,5 \pm 4,2$ & 96,0 & $0,5 \pm 0,23$ \\
\hline L. (V.) braziliensis & RPL/05/GF & $59,8 \pm 3,2$ & 136,2 & $1,7 \pm 0,14$ \\
\hline L. (V.) braziliensis & $\mathrm{TMB} / 06 / \mathrm{GO}$ & $29,1 \pm 4,6$ & 65,6 & $0,8 \pm 0,25$ \\
\hline L. (V.) braziliensis & UAF/06/TO & $31,6 \pm 9,7$ & 148,7 & $0,9 \pm 0,54$ \\
\hline L. (V.) braziliensis & WSS/05/GO & $44,8 \pm 2,3$ & 124,8 & $1,3 \pm 0,09$ \\
\hline L. (L.) amazonensis & MHOM/BR/73/M2269 & $54,6 \pm 5,5$ & 301,2 & - \\
\hline L. (L.) amazonensis & EGS/04/GO & $112,4 \pm 3,2$ & 238,7 & $2,05 \pm 0,30$ \\
\hline L. (L.) amazonensis & JRS/01/GO & $112,2 \pm 3,6$ & 197,7 & $2,05 \pm 0,28$ \\
\hline L. (L.) amazonensis & JSC/06/PA & $146,0 \pm 5,0$ & 296,8 & $2,67 \pm 0,35$ \\
\hline L. (L.) major-like & $\mathrm{MAB} / 03 / \mathrm{PA}$ & $138,3 \pm 20$ & 955,45 & - \\
\hline L. (L.) major-like & VBL/01/PA & $62,1 \pm 7,2$ & 341,6 & - \\
\hline
\end{tabular}

(-) não calculado. 


\subsection{Sensibilidade de amastigotas de alguns isolados de $L_{\text {. }}\left(V_{\text {.) }}\right)$ braziliensis in vitro ao tamoxifeno}

A sensibilidade de amastigotas ao tamoxifeno também foi avaliada. Foram utilizados alguns isolados de $L$. (V.) braziliensis além da cepa referência MHOM/BR/75/M2903 para infectar macrófagos obtidos de medula óssea de camundongos BALB/c. Esses macrófagos foram incubados com diferentes concentrações de tamoxifeno $(3,6,9$ e $12 \mu \mathrm{M})$ por 6 dias. Os valores de $\mathrm{Cl}_{50}$ e $\mathrm{Cl}_{90}$ para a cepa referência foram iguais a $8,0 \pm 3,7 \mu \mathrm{M}$ e $10,7 \mu \mathrm{M}$, respectivamente. $\mathrm{As}^{\mathrm{Cl}_{50}}$ s dos isolados avaliados variaram entre 1,9 $\pm 0,16 \mu \mathrm{M}$ e 6,9 $\pm 0,02 \mu \mathrm{M}$ e os valores determinados para $\mathrm{Cl}_{90}$ estavam entre 6 e 9,8 $\mu \mathrm{M}$ (Tabela 6).

Macrófagos infectados com a cepa referência foram avaliados também após $48 \mathrm{~h}$ de incubação com tamoxifeno. Nessas condições, $\mathrm{a} \mathrm{Cl}_{50}$ da cepa referência foi igual a 5,6 $\pm 0,3 \mu \mathrm{M}$ e $\mathrm{Cl}_{90}$ foi igual e a 9,0 $\mu \mathrm{M}$ (Tabela 6).

Portanto, observamos que os isolados foram sensíveis ao tamoxifeno mesmo quando incubados com a droga por um período mais curto, de $48 \mathrm{~h}$. A sensibilidade de amastigotas ao tamoxifeno foi semelhante à sensibilidade de promastigotas.

Tabela 6: Atividade in vitro de tamoxifeno contra amastigotas de Leishmania.

\section{Amastigotas}

\begin{tabular}{|c|c|c|c|c|}
\hline Espécie & Paciente/ano/local & $\begin{array}{l}I_{C_{50}} \pm D P \\
S b^{v} \mu \mathrm{g} / \mathrm{mL}\end{array}$ & $\begin{array}{c}\mathrm{IC}_{90} \\
\mathrm{Sb}^{\mathrm{v}} \mu \mathrm{g} / \mathrm{mL}\end{array}$ & $\begin{array}{l}\text { Razão de } \\
\text { resistência }\end{array}$ \\
\hline L. (V.) braziliensis & MHOM/BR/75/M2903 ${ }^{\mathrm{a}}$ & $5,6 \pm 0,3$ & 9,0 & - \\
\hline L. (V.) braziliensis & $\mathrm{MHOM} / \mathrm{BR} / 75 / \mathrm{M} 2903^{\mathrm{b}}$ & $8,0 \pm 3,7$ & 10,7 & - \\
\hline L. (V.) braziliensis & $\mathrm{BA} 788 / 01^{\mathrm{b}}$ & $1,9 \pm 0,16$ & 6,0 & $0,24 \pm 0,23$ \\
\hline L. (V.) braziliensis & $\mathrm{BES} / 06 / \mathrm{GO}^{\mathrm{b}}$ & $3,5 \pm 0,15$ & 7,3 & $0,44 \pm 0,47$ \\
\hline L. (V.) braziliensis & $\mathrm{EFSF} / 06 / \mathrm{GO}^{\mathrm{b}}$ & $6,9 \pm 0,02$ & 9,8 & $0,86 \pm 1,00$ \\
\hline L. (V.) braziliensis & $\mathrm{GDL} / 06 / \mathrm{GO}^{\mathrm{b}}$ & $3,0 \pm 0,3$ & 7,9 & $0,38 \pm 0,34$ \\
\hline
\end{tabular}

${ }^{\mathrm{a}} 48 \mathrm{~h} \mathrm{e}{ }^{\mathrm{b}} 6$ dias de incubação com tamoxifeno 


\subsection{Infecção em camundongos BALB/c}

Um dos objetivos desse trabalho era avaliar a eficácia de tamoxifeno no tratamento de infecções por L. (V.) braziliensis em modelo experimental murino. Para tanto, inicialmente buscamos definir as melhores condições de infecção e evolução da doença para que tal avaliação pudesse ser feita.

Foram inoculados $1 \times 10^{5}$ promastigotas dos isolados de L. (V.) braziliensis MHOM/BR/01/BA e UAF/06/TO na orelha esquerda de fêmeas de camundongos BALB/C e $5 \times 10^{5}$ promastigotas dos mesmos isolados na pata posterior esquerda e cauda. Os camundongos foram observados a cada 3 dias. A espessura da orelha e da pata $\mathrm{e}$ diâmetro da cauda foram medidos com um paquímetro (Mitutoyo) semanalmente durante 12 semanas. Na pata, a infecção dos isolados UAF/06/TO e MHOM/BR/01/BA resultou em pequeno edema que se iniciou na quinta semana (Figura 15 A). Na cauda, a inoculação não induziu lesões detectáveis (Figura 15 B). A lesão na orelha após infecção com os isolados UAF/06/TO e MHOM/BR/01/BA atingiu tamanho máximo na décima semana $(0,8 \pm 0,5 \mathrm{~mm})$ e na quinta semana $(1 \pm 0,4 \mathrm{~mm})$, respectivamente. Na última semana, os animais estavam clinicamente curados (Figura 15 C e D). Em todos os casos, o aparecimento da lesão foi muito rápido e evoluiu para cura clínica em até 12 semanas (Figura 15 A, C e D). Observamos que o inóculo de $10^{5}$ promastigotas de $L$. (V.) braziliensis induziu lesão na orelha na maioria dos camundongos infectados e a lesão atingiu tamanho máximo de $1 \mathrm{~mm}$ na quinta semana (Figura 15 D). 

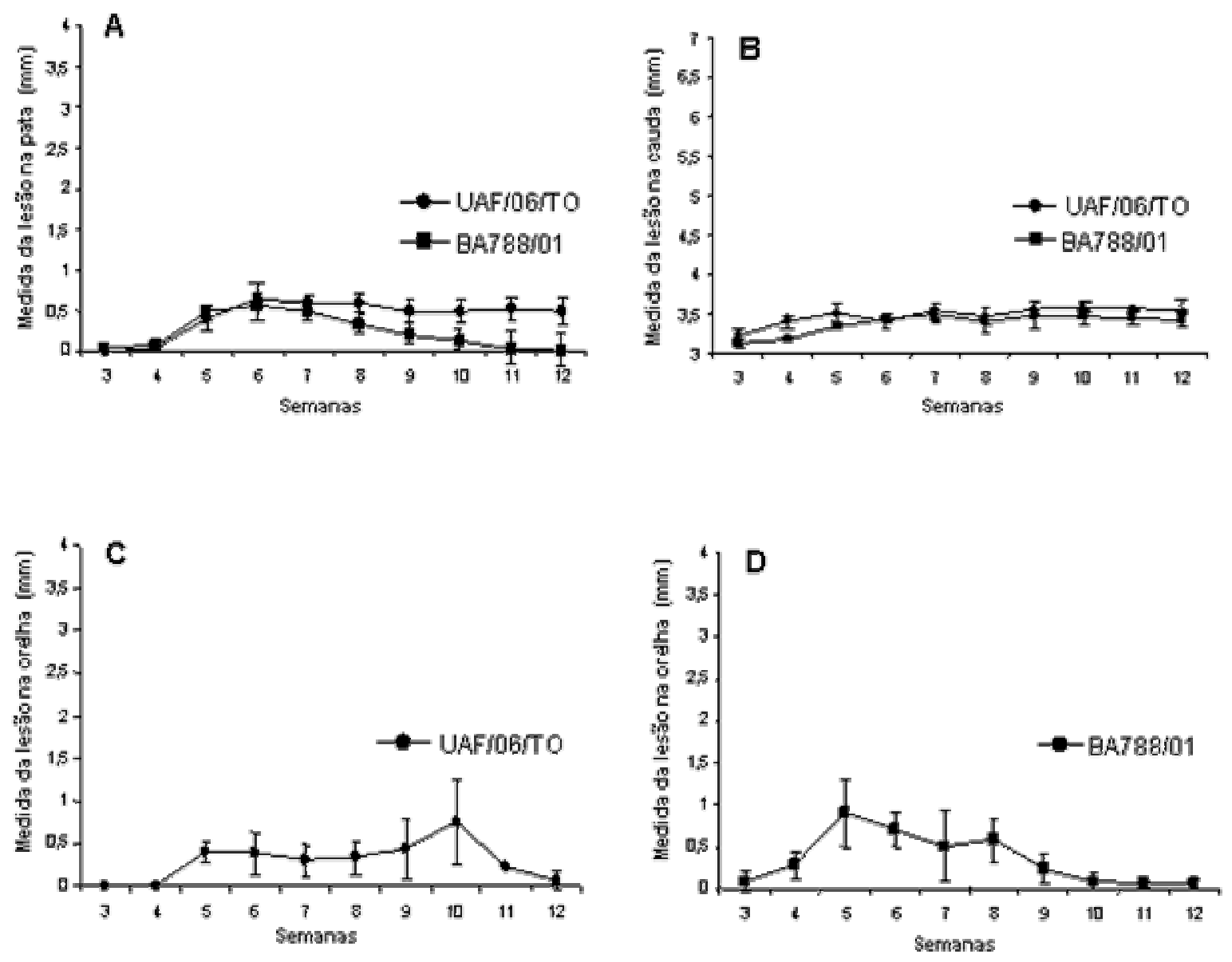

Figura 15: Inóculo de $5 \times 10^{5}$ promastigotas de $L$. (V.) braziliensis na pata posterior esquerda (A), cauda (B) ou $1 \times 10^{5}$ promastigotas na derme da orelha esquerda de fêmeas de camundongos $B A L B / c$ ( $C$ e D). O desenvolvimento da lesão foi monitorado por 12 semanas. O tamanho em milímetros está mostrado como a média e o desvio padrão de dois experimentos independentes, cada um realizado com grupos de 7 animais. As medidas da lesão na pata ou orelha são apresentadas como a diferença da medida da pata ou orelha infectada e a contralateral; a medida da cauda é representada pelo diâmetro médio. 
Após 5 semanas do inóculo na orelha os camundongos foram fotografados. Pôde ser observado através do aspecto macroscópico da lesão que o isolado BA788/01 apresentou maior lesão (Figura 16 A e B).
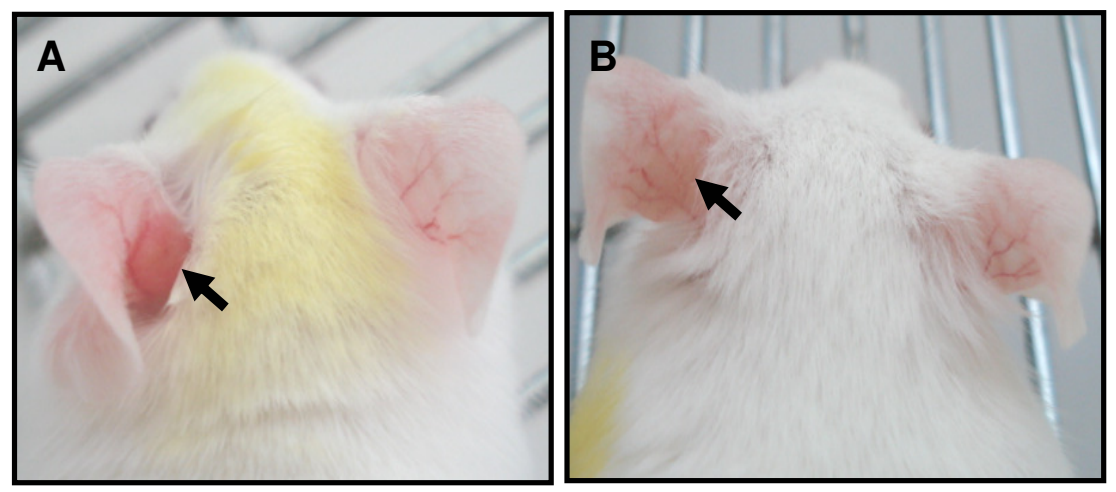

Figura 16: Aspecto da lesão na orelha após 5 semanas do inóculo. Promastigotas $\left(1 \times 10^{5}\right)$ de $L$. $(V$.) braziliensis foram inoculados na derme da orelha esquerda de fêmeas de camundongos BALB/c. (A) BA788/01; (B) UAF/06/TO.

Ao final do período de observação (12 semanas), avaliamos também o aspecto histopatológico da lesão. Pôde ser observada uma reação inflamatória no local do inóculo (Figura 17 B e D), quando comparada com a orelha sem parasitas (Figura 17 A). Foi observado reduzido número de parasitas nas lesões, revelado pela existência de vacúolos pequenos e poucos amastigotas por vacúolo (Figura 17 C e E).

Considerando as características da lesão, da evolução clínica e do aspecto histopatológico, elegemos o modelo de infecção no pavilhão auricular com o isolado MHOM/BR/01/BA para análise da eficácia do tratamento com tamoxifeno. Concluímos também que a análise histopatológica não seria um método sensível para avaliar o sucesso do tratamento, já que a lesão evoluía naturalmente para acentuada redução no número de amastigotas. 


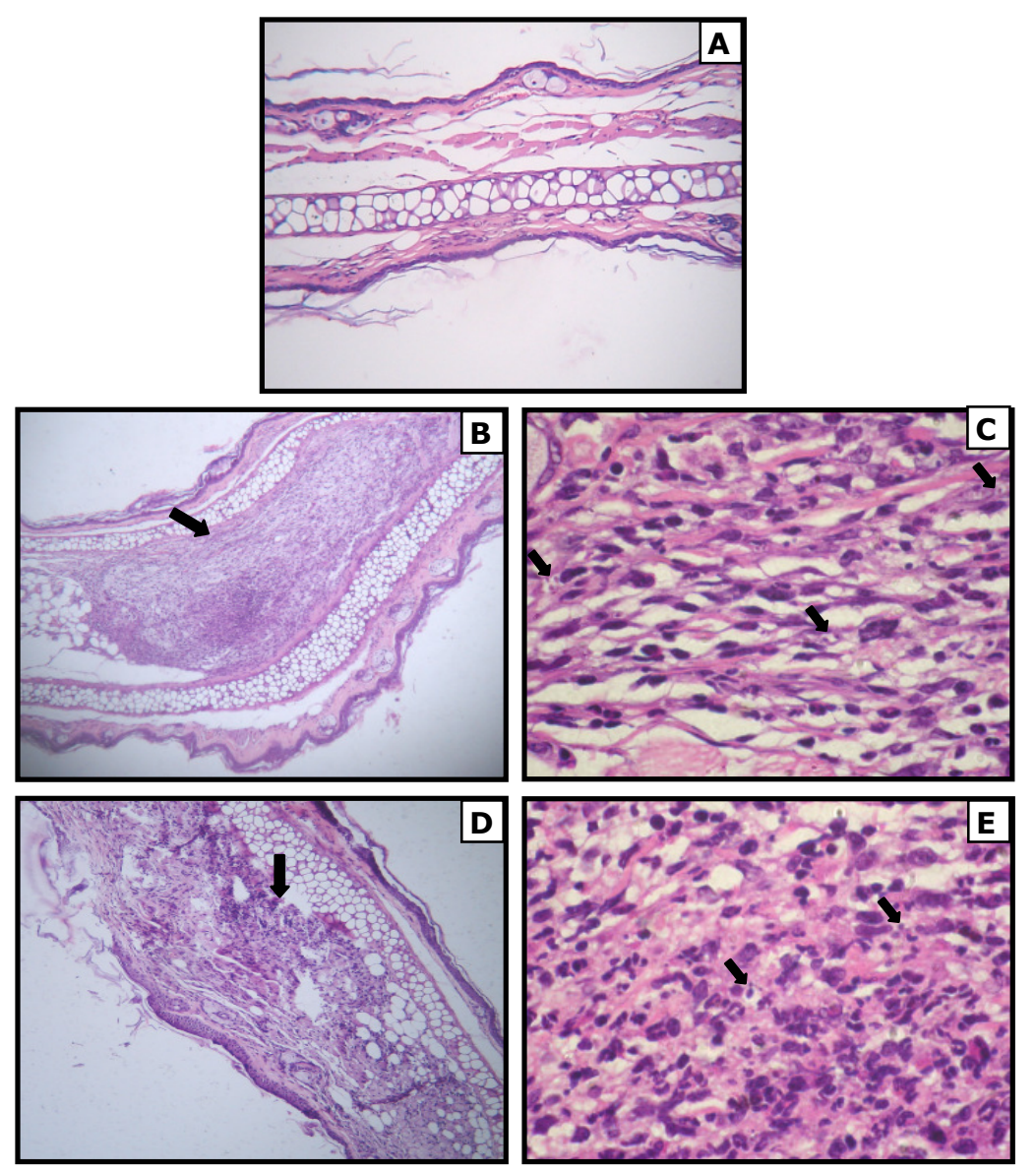

Figura 17: Aspecto histopatológico da lesão na orelha de camundongo BALB/c após inóculo de promastigotas de L. (V.) braziliensis. A: Controle não infectado; B e C: isolado BA788/01, lesão curada mostrando reação inflamatória indicada pela seta preta (Aumento de 40x) em (B) e parasitas dentro do vacúolo em (C) (Aumento de 1000x). $D$ e $E$ : isolado UAF/06/TO, lesão curada em (D) (40x) e parasitas indicados pelas setas em (E) (Aumento de 1000x). 


\subsection{Tratamento por via tópica e intraperitonial (IP) com tamoxifeno, anfotericina B e Glucantime ${ }^{\circledR}$}

Camundongos BALB/c inoculados por via intradérmica com $1 \times 10^{5}$ promastigotas de MHOM/BR/01/BA788 foram utilizados para testes de eficácia de tamoxifeno in vivo. Grupos infectados foram também tratados com anfotericina B e Glucantime ${ }^{\circledR}$, utilizados como controles positivos do tratamento. A administração das drogas foi iniciada 3 semanas após o inóculo, que foi o tempo de aparecimento da lesão observado nos experimentos anteriores.

A administração por via tópica de tamoxifeno foi realizada aplicando-se doses de $20 \mathrm{mg} / \mathrm{Kg} /$ dia da droga no local da lesão, preparada em etanol contendo $10 \%$ de glicerol. O esquema inicial proposto era de tratamento durante 15 dias, mas a orelha ficou ressecada, começou a descascar e foi observado também eritema e edema (Figura 18). Com o grupo tratado somente com o veículo aconteceu o mesmo, mas em menor intensidade (dados não apresentados). Devido a esses resultados, suspendemos o tratamento por via tópica por 7 dias e retornamos aplicando a droga por mais 5 dias. Foram observadas as mesmas reações ocorridas anteriormente.

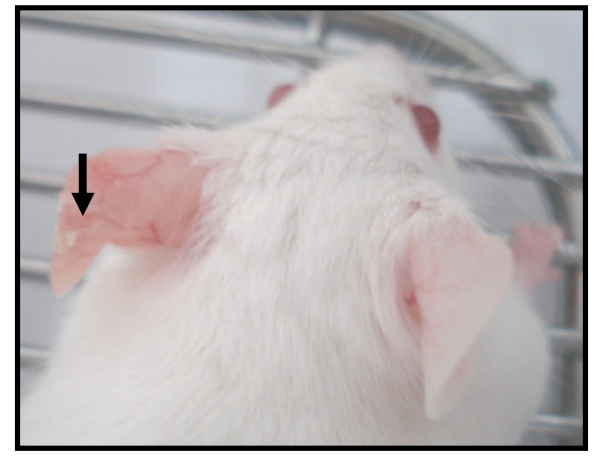

Figura 18: Aspecto da lesão na orelha após 2 semanas do tratamento tópico com tamoxifeno. Promastigotas $\left(1 \times 10^{5}\right)$ de $L$. (V.) braziliensis (MHOM/BR/01/BA788) foram inoculados na derme da orelha esquerda de fêmeas de camundongos BALB/c e iniciado o tratamento após 3 semanas. 
A administração por via intraperitonial foi realizada com citrato de tamoxifeno (10 $\mathrm{mg} / \mathrm{Kg} / \mathrm{dia}$, $20 \mathrm{mg} / \mathrm{Kg} / \mathrm{dia}$ e $30 \mathrm{mg} / \mathrm{Kg} / \mathrm{dia}$ ), com 15 doses em dias consecutivos, anfotericina B (0,5 mg/Kg/dia) 6 doses em dias alternados e Glucantime ${ }^{\circledR}(20 \mathrm{mg} / \mathrm{Kg} / \mathrm{dia})$ por 15 dias consecutivos. O grupo controle recebeu somente salina por 15 dias consecutivos.

A medida da orelha infectada foi subtraída da medida da orelha sem lesão de cada camundongo. A média dos valores da espessura da orelha foi calculada de acordo com 3 experimentos realizados independentemente. Na sexta semana, a média dos valores da espessura da orelha foi de $0,38 \pm 0,07 \mathrm{~mm}$ para os camundongos tratados com salina enquanto que nos grupos tratados com tamoxifeno a espessura da lesão foi de 0,26 \pm 0,05 mm (10 mg/Kg/dia), 0,18 $\pm 0,06 \mathrm{~mm}(20 \mathrm{mg} / \mathrm{Kg} / \mathrm{dia})$ e $0,17 \pm 0,05 \mathrm{~mm}$ (30 $\mathrm{mg} / \mathrm{Kg} / \mathrm{dia}$ ) no mesmo período. No grupo tratado com anfotericina $\mathrm{B}$ a espessura da lesão foi de $0,10 \pm 0,05 \mathrm{~mm}$ na sexta semana e no grupo tratado com Glucantime ${ }^{\circledR}$ a espessura foi de 0,20 $\pm 0,05 \mathrm{~mm}$ no mesmo período. O grupo tratado por via tópica com tamoxifeno também foi avaliado e a espessura da lesão foi de 0,35 $\pm 0,1 \mathrm{~mm}$ (Figura 19).

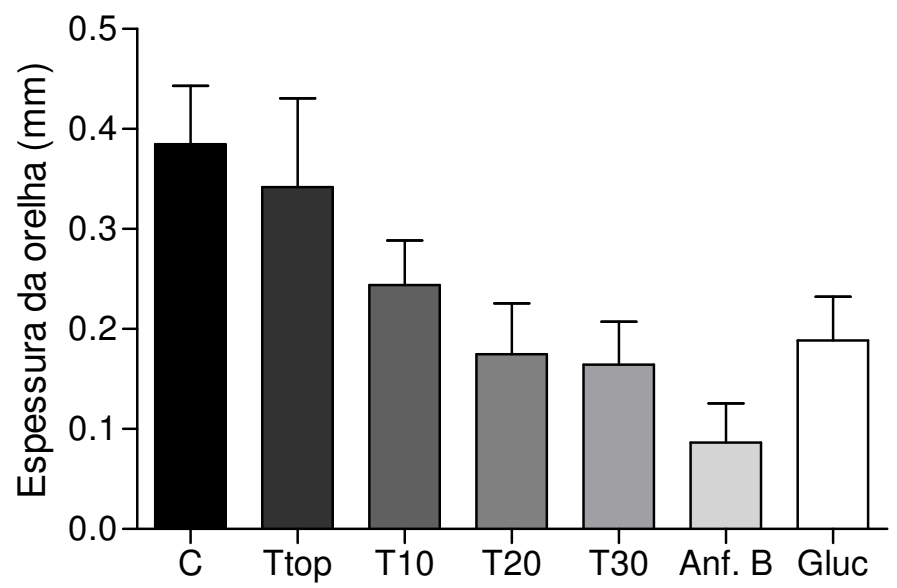

Figura 19: Média dos valores da espessura da lesão na orelha após 6 semanas do inóculo e 1 semana após o término do tratamento. Promastigotas $\left(1 \times 10^{5}\right)$ de $L$. $(V$. $)$ braziliensis (MHOM/BR/01/BA788) foram inoculados na derme da orelha esquerda de fêmeas de camundongos BALB/c e iniciado o tratamento após 3 semanas. C (Grupo controle tratado com salina); Ttop (tamoxifeno por via tópica); T10 (10 mg/Kg/dia de tamoxifeno); T20 (20 mg/Kg/dia); T30 (30 mg/Kg/dia); Anf.B (0,5 mg/Kg/dia de anfotericina B) e Gluc $\left(20 \mathrm{mg} / \mathrm{Kg} /\right.$ dia de Glucantime $\left.{ }^{\circledR}\right)$. Espessura da orelha=diferença entre a medida da orelha infectada e a contralateral. $P<0,05$ (T20, T30, Anf. B e Gluc vs grupo controle não tratado). 
A atividade da droga pôde ser analisada também através do aspecto macroscópico da lesão (Figura 20). Observamos que o tratamento com tamoxifeno administrado por via intraperitonial resultou em retardamento ou ausência do desenvolvimento de lesão em camundongos infectados com 0 isolado MHOM/BR/01/BA788 de L. (V.) braziliensis. A maioria dos camundongos do grupo controle tiveram lesão aparente. Aproximadamente 30\% dos camundongos tratados apresentaram lesões menores do que o grupo controle e os restantes não apresentaram lesões aparentes (Figura 20).

Os camundongos foram pesados antes e após o tratamento e não foram observadas diferenças no peso dos camundongos tratados com tamoxifeno, anfotericina B ou Glucantime ${ }^{\circledR}$ em relação ao controle tratado com salina. Foi avaliado o peso de cada camundongo individualmente e nenhum apresentava-se abaixo de $20 \mathrm{~g}$. Então, calculamos a média dos pesos dos camundongos de cada grupo (Tabela 7). 


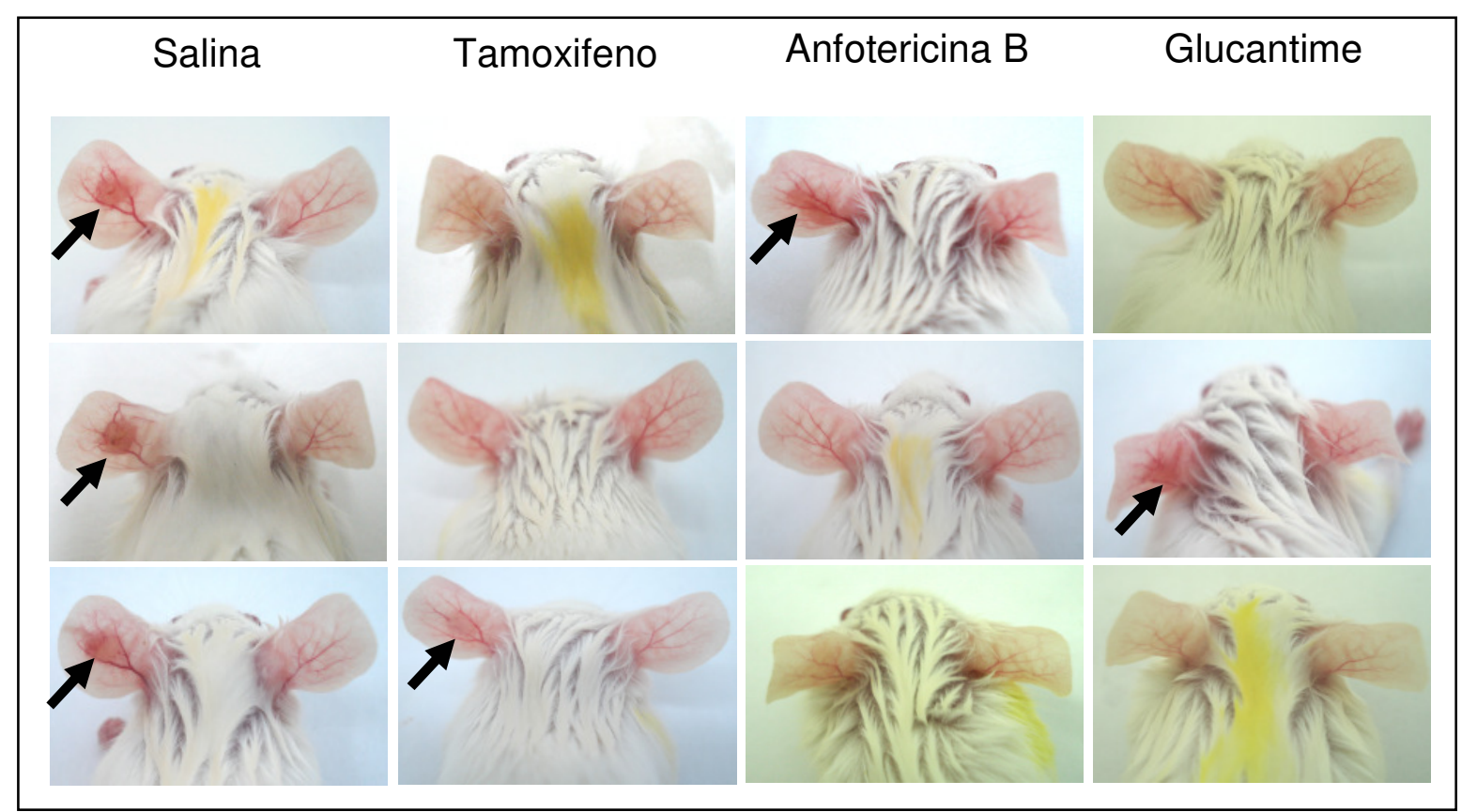

Figura 20: Aspecto da lesão na orelha 2 semanas após o término do tratamento. Promastigotas (1 $x 10^{5}$ ) de $L$. (V.) braziliensis (MHOM/BR/01/BA788) foram inoculados na derme da orelha esquerda de fêmeas de camundongos BALB/c e iniciado o tratamento após 3 semanas com tamoxifeno, anfotericina B ou Glucantime ${ }^{\circledR}$. O grupo controle recebeu salina durante o tratamento.

Tabela 7: Média do peso dos camundongos anterior e posterior ao tratamento

\begin{tabular}{|c|c|c|}
\hline Tratamento & $\begin{array}{l}\text { Média do peso } \\
\text { Anterior (g) }\end{array}$ & $\begin{array}{c}\text { Média do peso } \\
\text { Posterior (g) }\end{array}$ \\
\hline Controle (Salina) & $23,3 \pm 2,0$ & $24,1 \pm 0,91$ \\
\hline Tamoxifeno $10 \mathrm{mg} / \mathrm{Kg} / \mathrm{d}$ ) & $23,7 \pm 0,06$ & $24,3 \pm 0,05$ \\
\hline Tamoxifeno $20 \mathrm{mg} / \mathrm{Kg} / \mathrm{d}$ & $22,6 \pm 0,70$ & $25,5 \pm 0,11$ \\
\hline Tamoxifeno $30 \mathrm{mg} / \mathrm{Kg} / \mathrm{d}$ & $23,6 \pm 1,93$ & $24,5 \pm 1,36$ \\
\hline Tamoxifeno Tópico & $21,5 \pm 1,08$ & $25,8 \pm 1,20$ \\
\hline Anfotericina B $0,5 \mathrm{mg} / \mathrm{Kg} / \mathrm{d}$ & $22,1 \pm 1,30$ & $24,8 \pm 0,90$ \\
\hline Glucantime ${ }^{\circledR} 20 \mathrm{mg} / \mathrm{Kg} / \mathrm{d}$ & $23,9 \pm 1,60$ & $24,1 \pm 2,0$ \\
\hline
\end{tabular}

(g) gramas. 


\subsection{Quantificação de parasitas por diluição limitante}

A eficácia do tratamento foi também avaliada quantificando-se a carga parasitária dos animais tratados. A remoção das lesões foi feita 7 semanas após a infecção com o isolado MHOM/BR/01/BA788 de $L$. (V.) braziliensis e portanto 2 semanas após o final do tratamento. $O$ teste de diluição limitante foi realizado com 5 camundongos por grupo e foi calculada a média do número de parasitas. No controle tratado com salina foram quantificados $1 \times 10^{6}$ parasitas enquanto que no grupo tratado com 20 ou $30 \mathrm{mg} / \mathrm{Kg} / \mathrm{dia}$ de tamoxifeno por via intraperitonial foram detectados menos de $1 \times 10^{4}$ parasitas, observando-se portanto uma diminuição maior que 100 vezes no grupo tratado com 20 $\mathrm{mg} / \mathrm{Kg} / \mathrm{dia}$ de tamoxifeno em relação ao controle. O número de parasitas encontrado na lesão do grupo tratado com $10 \mathrm{mg} / \mathrm{Kg} / \mathrm{dia}$ de tamoxifeno por via intraperitonial e com tamoxifeno por via tópica foi maior que $1 \times 10^{4}$ parasitas. Nos grupos que receberam anfotericina B ou Glucantime ${ }^{\circledR}$ havia menos de $1 \times 10^{3}$ parasitas (Figura 21).

A carga parasitária foi analisada nos 3 experimentos realizados independentemente.

Em um dos experimentos realizados para avaliar a eficácia das drogas foi analisada também a carga parasitária do linfonodo retroauricular. A remoção do linfonodo foi obtida logo após a remoção da orelha infectada. O teste de diluição limitante do linfonodo foi realizado como descrito nos materiais e métodos para o teste de diluição limitante da orelha. O número de parasitas encontrado nos linfonodos foi baixo, por volta de 500 parasitas no grupo controle que recebeu somente salina. Aproximadamente 100 parasitas foram quantificados nos grupos tratados com 10 ou $20 \mathrm{mg} / \mathrm{Kg} / \mathrm{dia}$ de tamoxifeno por via intraperitonial e pouco mais de 10 parasitas no grupo tratado com Glucantime ${ }^{\circledR}$ (Figura 22).

O tratamento de camundongos BALB/C infectados na orelha com $L$. (V.) braziliensis mostrou-se eficaz quando administrado por via intraperitonial. Doses de 20 ou $30 \mathrm{mg} / \mathrm{Kg} /$ dia de tamoxifeno foram igualmente eficazes.

Parte dos resultados apresentados nesse item é também descrita no trabalho publicado "Tamoxifen as a potential antileishmanial agent: efficacy in the treatment of Leishmania braziliensis and Leishmania chagasi infections - Journal of Antimicrobial Chemotherapy“ (Anexo B). 


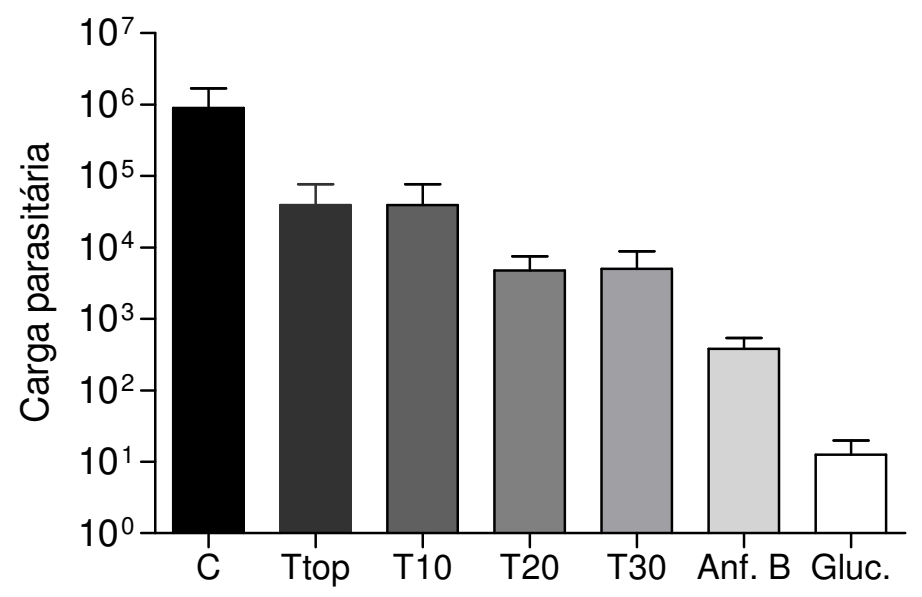

Figura 21: Carga parasitária da lesão de camundongos BALB/C após inoculação intradérmica na orelha com $L$. (V.) braziliensis. Os camundongos foram infectados com $1 \times 10^{5}$ promastigotas e o experimento realizado 2 semanas após o tratamento. C, controle tratado com salina; Ttop, tratamento com tamoxifeno por via tópica; T10, tratado com $10 \mathrm{mg} / \mathrm{Kg} /$ dia de tamoxifeno; T20, $20 \mathrm{mg} / \mathrm{Kg} /$ dia de tamoxifeno; T30, $30 \mathrm{mg} / \mathrm{Kg} / \mathrm{dia}$ de tamoxifeno; Anf. B, tratado com anfotericina B e Gluc., tratado com Glucantime ${ }^{\circledR}$. $P<$ 0,05 (T20, T30, Anf. B e Gluc vs grupo controle não tratado).

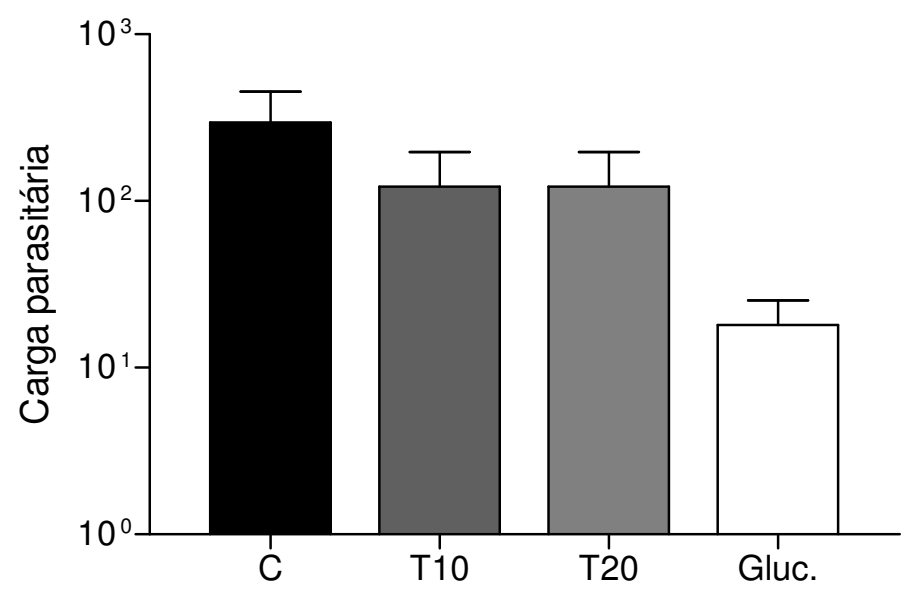

Figura 22: Carga parasitária do linfonodo de camundongos BALB/c após inoculação intradérmica na orelha com $L$. (V.) braziliensis. Os camundongos foram infectados com $1 \times 10^{5}$ promastigotas e o experimento realizado 2 semanas após o tratamento. C, controle tratado com salina; T10, tratado com $10 \mathrm{mg} / \mathrm{Kg} / \mathrm{dia}$ de tamoxifeno; T20, $20 \mathrm{mg} / \mathrm{Kg} / \mathrm{dia}$ de tamoxifeno e Gluc., tratado com Glucantime ${ }^{\circledR}$. 


\subsection{Caracterização do isolado EFSF/06/GO}

Após obtenção e identificação dos isolados, observamos por microscopia óptica que a morfologia de promastigotas do isolado EFSF/06/GO apresentava um aspecto atípico, distinto da forma promastigota convencional. Os promastigotas eram pequenos, pouco móveis, apresentavam flagelo muito curto ou não visível e uma estrutura arredondada próxima ao bolso flagelar (Figura 23 A e B).

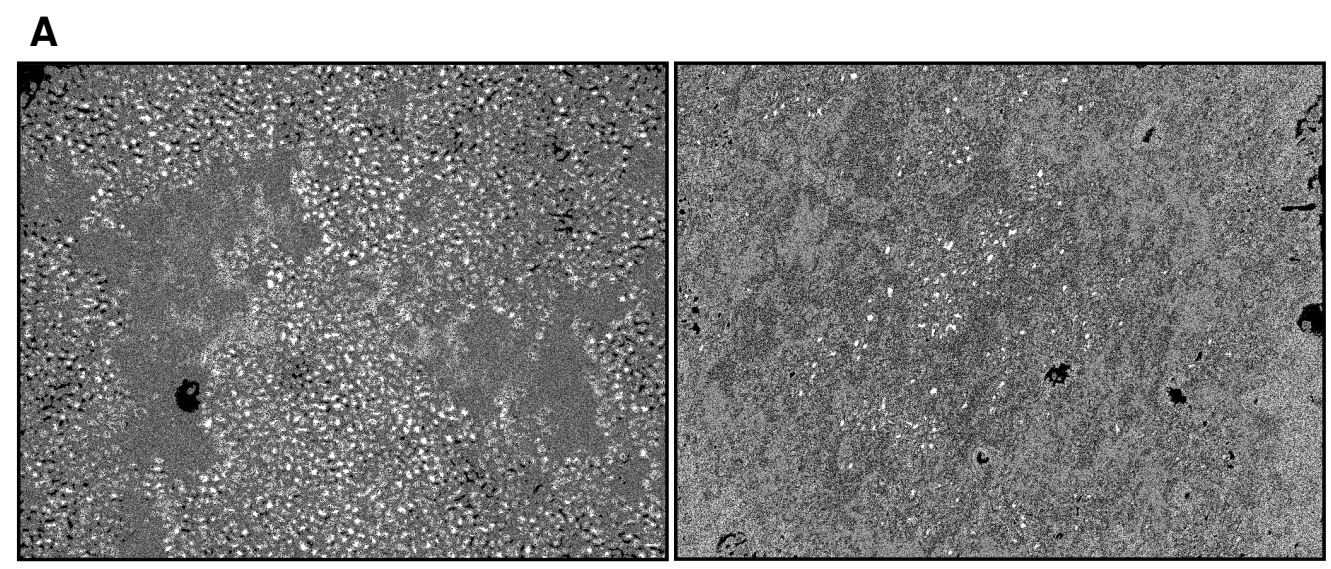

B

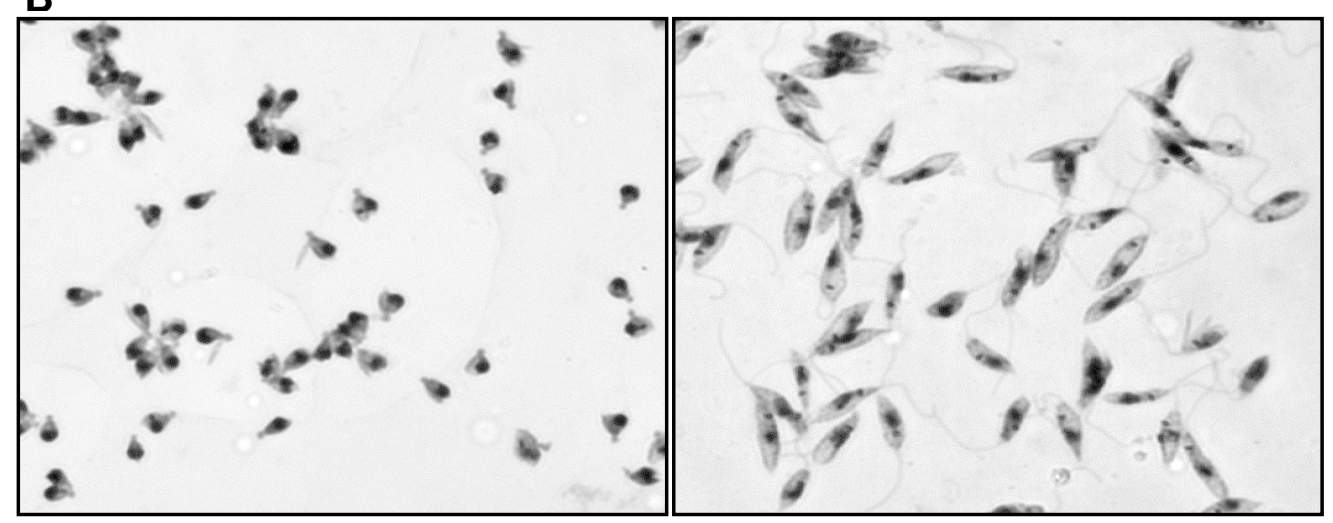

Figura 23: Microscopia óptica de promastigotas do isolado EFSF/06/GO e da cepa referência MHOM/BR/1975/M2903. (A) cultura de parasitas a $25{ }^{\circ} \mathrm{C}$ em microscópio óptico invertido (B) promastigotas corados com Instant Prov (aumento de 1000X). 
Nossa primeira preocupação foi confirmar que se tratava de um isolado de Leishmania. Como já descrito, o isolado EFSF/06/GO foi tipado como L. (V.) braziliensis por PCR de G6PD (Glucose-6 fosfato desidrogenase) e META2 e por anticorpos monoclonais. Ainda no sentido de obter mais dados relativos a esse isolado, amplificamos, clonamos e seqüenciamos as regiões ITS1, 5.8S e ITS2 (espaçadores internos transcritos) do gene ribossômico desse isolado.

A sequência obtida foi alinhada com sequências de diversas espécies de Leishmania disponíveis no GeneBank (L. (L.) chagasi (AJ000305.1), L. (L.) donovani (AJ000293.1, AM901450.1), L. (L.). major (AJ000310.1, DQ300195),L. (L.) amazonensis (AJ000314),L. (L.) mexicana (AF466383, AF466380.1), L. (V.) guyanensis (FJ753387, AJ000299.1, AJ000300.1), L. (V.) braziliensis (AJ300483, AJ300484, AJ300483) e Leptomonas mirabilis (AY180153.1)). Ao compararmos as sequências de nucleotídeos das regiões ITS1, 5.8S e ITS2 das espécies obtidas do GeneBank com a sequência do isolado EFSF/06/GO, observamos identidade de 97 e $98 \%$ com as sequências de $L$. (V.) braziliensis e $98 \%$ com as sequências de L. (V.) guyanensis (Anexo C). Como esperado, esse isolado agrupou-se com as espécies do subgênero Viannia observado através da árvore de máxima parcimônia construída no programa PAUP* 4.0 (Figura 24). Portanto, a tipagem foi extensivamente confirmada como $L$. (V.) braziliensis.

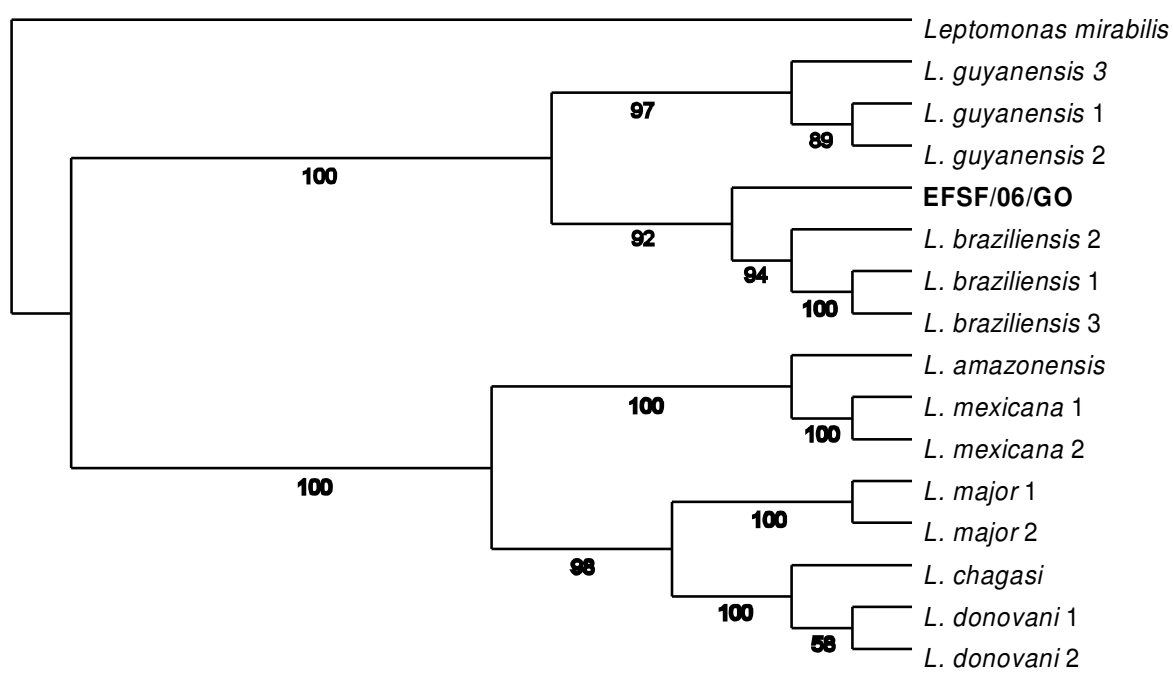

Figura 24: Árvore de máxima parcimônia construída no PAUP* 4.0, baseada no alinhamento das sequências de nucleotídeos das regiões ITS1, 5.8S e ITS2 das espécies obtidas do GeneBank e da sequência do isolado EFSF/06/GO. Os números se referem aos valores de bootstrap de 100 replicatas. 


\subsubsection{Microscopia óptica e curva de crescimento}

Como a temperatura pode interferir na morfologia do parasita, mantivemos também as culturas a $22{ }^{\circ} \mathrm{C}$. As culturas do isolado EFSF/06/GO e da cepa referência foram mantidas paralelamente nas duas temperaturas e analisadas por aproximadamente 2 meses. Não foram observadas alterações na morfologia de promastigotas que mantiveram a forma observada a $25^{\circ} \mathrm{C}$ (dados não apresentados).

Avaliamos também a curva de crescimento do isolado EFSF/06/GO. Inicialmente, incubamos $3 \times 10^{5}$ promastigotas $/ \mathrm{mL}$ em meio 199 a $25{ }^{\circ} \mathrm{C}$. Foi observado que o crescimento do isolado EFSF/06/GO é um pouco mais acelerado do que o crescimento da cepa referência MHOM/BR/1975/M2903. O isolado atingiu a fase estacionária no quarto dia e a cepa referência no quinto dia. No sexto dia já havia ocorrido diminuição de promastigotas vivos nas duas culturas (Figura 25).

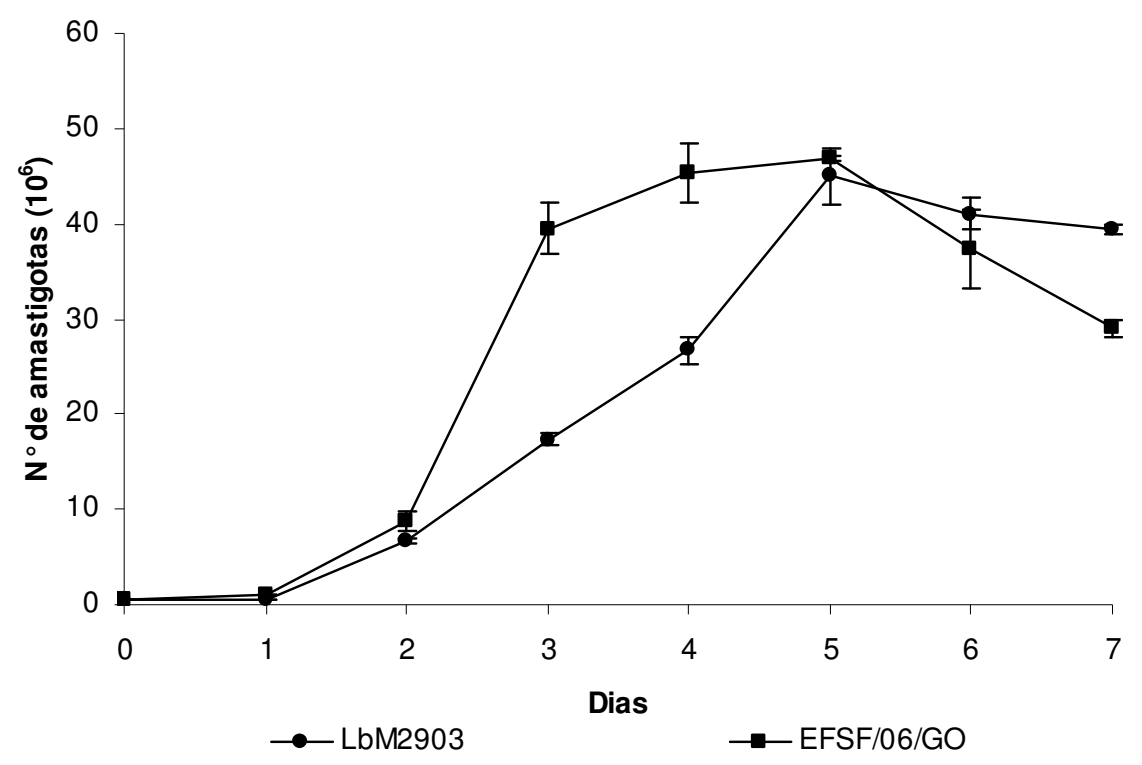

Figura 25: Curva de crescimento de promastigotas do isolado EFSF/06/GO e da cepa referência MHOM/BR/1975/M2903 mantidos em estufa a $25^{\circ} \mathrm{C}$ em meio $199 \mathrm{com} 10 \%$ de SFB e $2 \%$ de urina masculina humana estéril. 


\subsubsection{Infecção de macrófagos in vitro e de camundongos BALB/c com o isolado EFSF/06/GO}

Avaliamos então a infecção in vitro de macrófagos derivados de medula óssea e in vivo de camundongos BALB/c com o isolado EFSF/06/GO. A infecção in vivo foi obtida através do inoculo de $1 \times 10^{5}$ promastigotas de 5 dias de cultivo na orelha dos camundongos. Os resultados in vitro mostraram os padrões típicos de infecção de macrófagos observados para a espécie L. (V.) braziliensis, que é caracterizada pela existência de vacúolos pequenos com poucos amastigotas por vacúolo (Figura 26). A lesão causada na orelha de camundongos BALB/c foi semelhante à infecção por $L$. (V.) braziliensis apresentada na Figura 20. O aparecimento e cura da lesão foram rápidos, sendo que o edema foi detectado a partir da terceira semana e na décima semana todos os animais estavam clinicamente curados (dados não apresentados). $O$ exame histopatológico da orelha de um desses camundongos infectados permitiu observação da reação inflamatória no local do inóculo, mas não foi possível identificar amastigotas no tecido (Figura 27). 


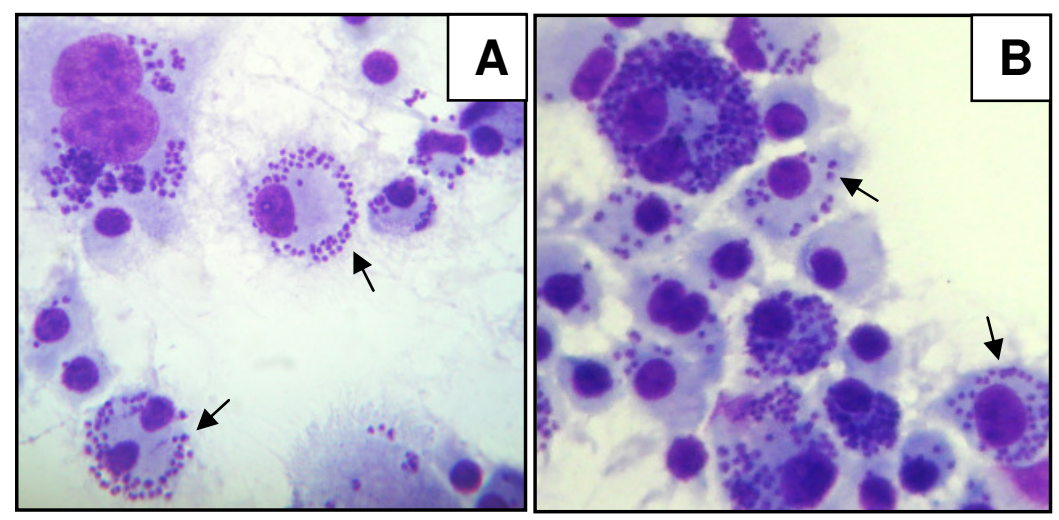

Figura 26: Infecção de macrófagos de medula por L. (V.) braziliensis EFSF/06/GO (A) e cepa referência MHOM/BR/1975/M2903 (B). Proporção de 15 parasitas/macrófago durante 3 horas a $33{ }^{\circ} \mathrm{C}$ e $5 \% \mathrm{CO}_{2}$. A infecção foi mantida por 6 dias nessas condições (1000X).

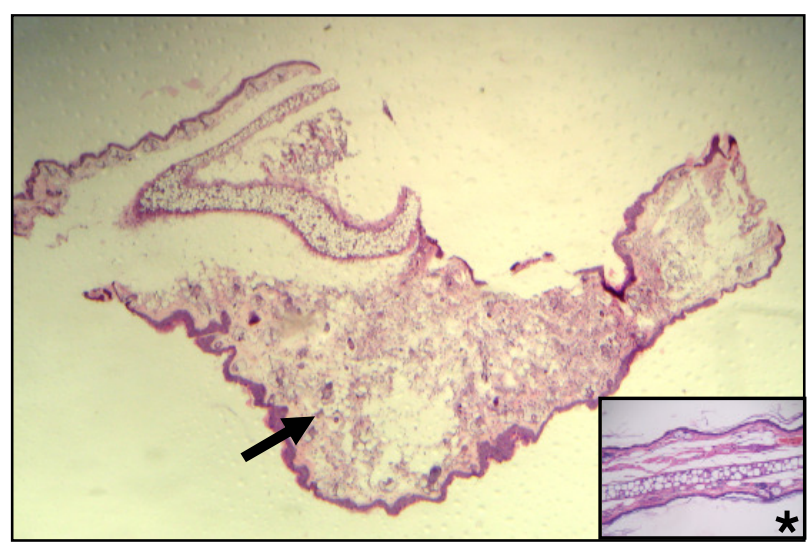

Figura 27: Aspecto histopatológico da lesão na orelha de camundongo BALB/c após 3 semanas do inóculo de $1 \times 10^{5}$ promastigotas do isolado (EFSF/06/GO). Reação inflamatória (seta preta). * Corte da orelha não infectada. (Aumento de 40X). 


\subsubsection{Microscopia eletrônica de transmissão e microscopia eletrônica de varredura}

Para aprofundar a análise morfológica, foi realizada microscopia eletrônica de transmissão e microscopia eletrônica de varredura de promastigotas de cultura. Amastigotas de lesão induzida na orelha de camundongos BALB/c foram analisados somente por microscopia eletrônica de transmissão. Foram identificadas estruturas características de tripanosomatídeos como mitocôndria única contendo DNA mitocondrial e bolso flagelar (Figura 28). Em promastigotas, verificamos a presença de uma estrutura arredondada em formato de "bainha" (indicada pela seta) localizada na extremidade anterior. Cortes transversais de flagelo foram observados raramente, mas continham um axonema típico (Figura 28 A). No caso das preparações de tecido infectado, observamos a presença de amastigotas típicos, confirmando a infectividade do isolado em camundongos. Nesses amastigotas de lesão o flagelo encontrava-se reduzido como descrito para esta forma e estavam presentes em vacúolo pequeno e com poucos amastigotas por vacúolo, como descrito para infecções por L. (V.) braziliensis (Figura 28 B).

Em promastigotas de fase logarítmica do isolado EFSF/06/GO foram também observados presença de vacúolo grande próximo ao bolso flagelar e citoplasma com muitos acidocalcissomos (Figura 29 A e B), assim como alterações na membrana do flagelo e bolso flagelar (indicada pelas setas) (Figura 29 C e D). 

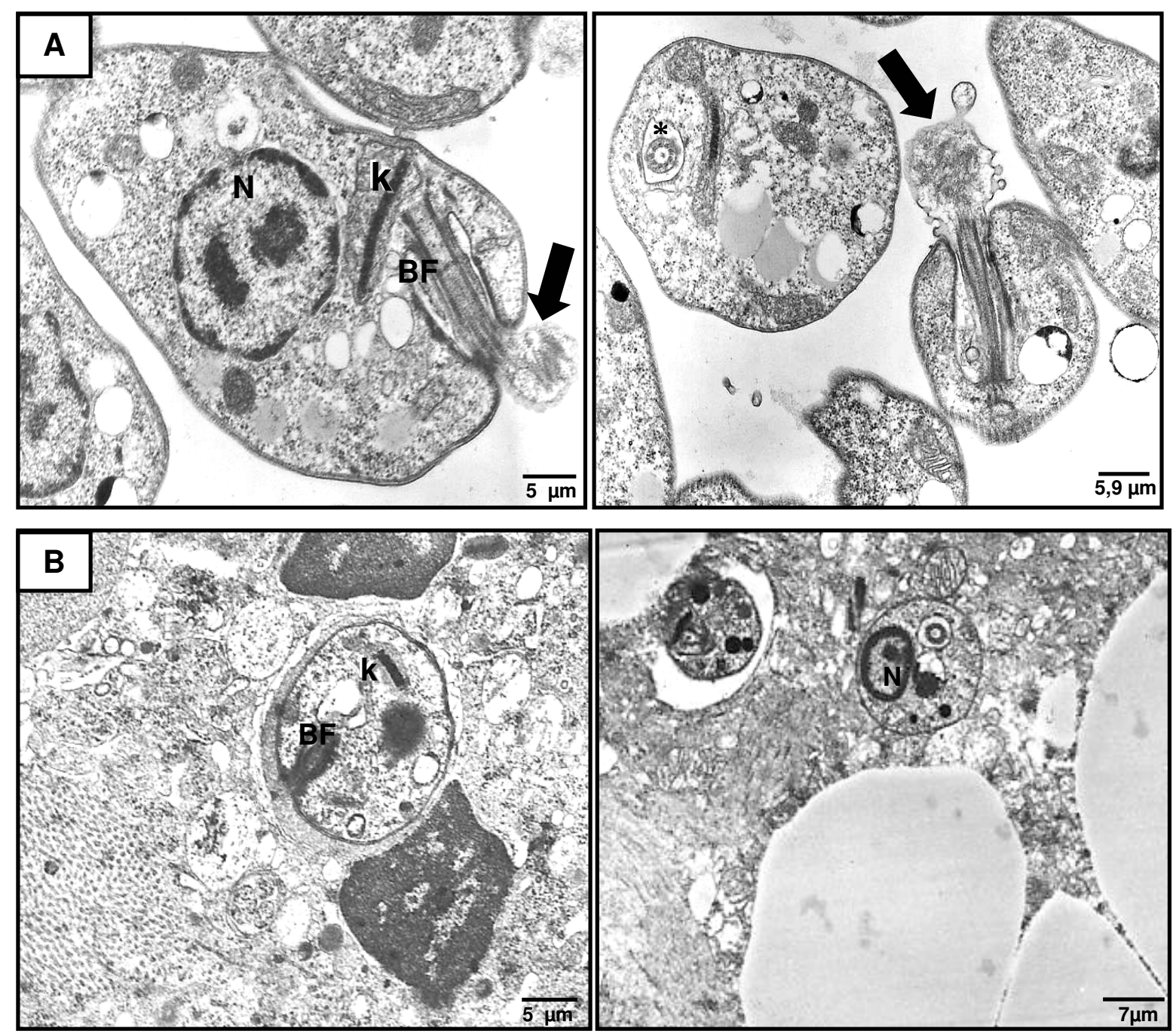

Figura 28: Microscopia eletrônica de transmissão de promastigotas do isolado EFSF/06/GO em fase logarítmica (A) e amastigotas no tecido infectado (B). (N) núcleo, (k) DNA cinetoplasto, (BF) bolso flagelar e (*) axonema. 


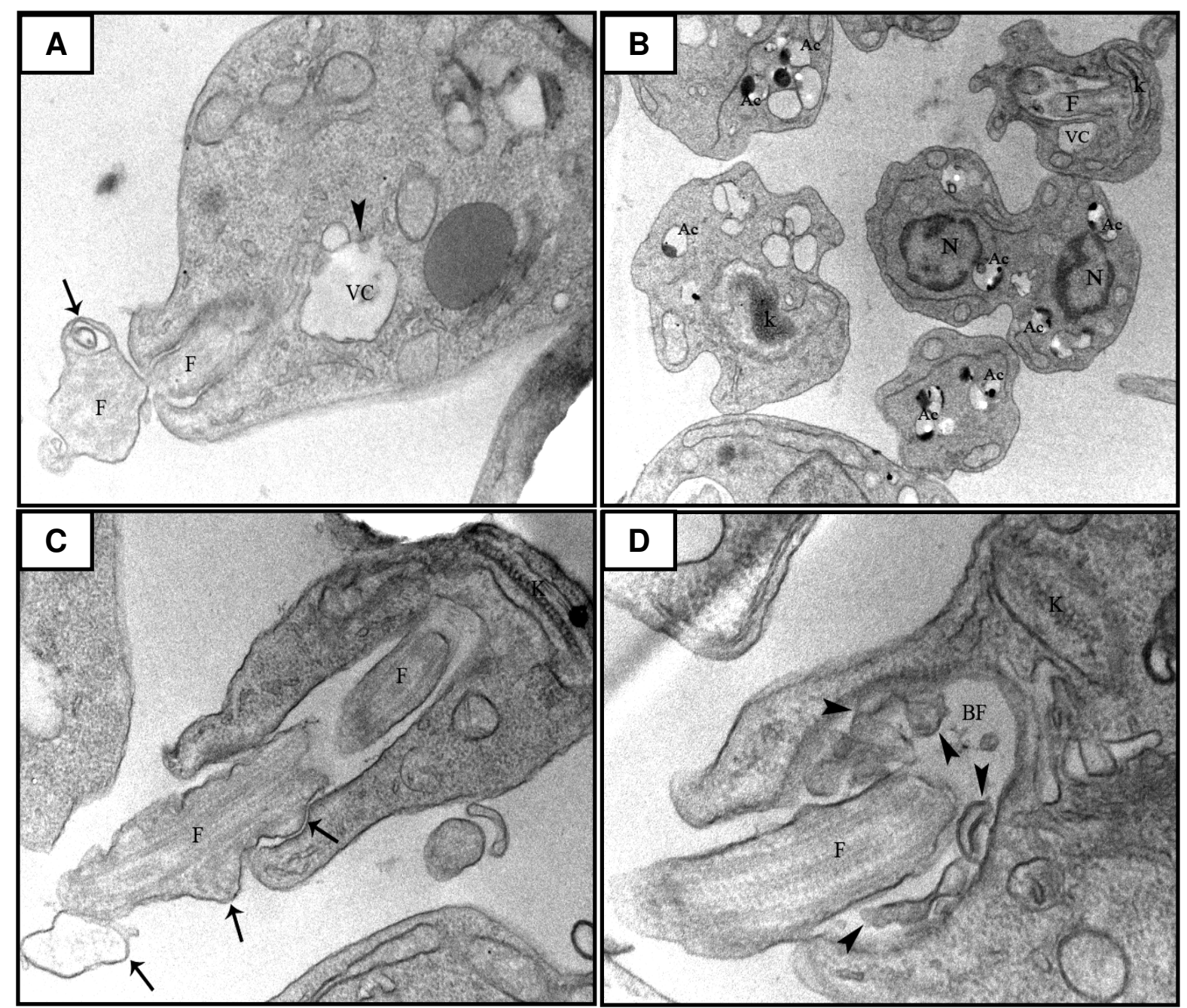

Figura 29: Microscopia eletrônica de transmissão de promastigotas do isolado $E F S F / 06 / G O$ em fase logarítmica. (A), (C) e (D) região anterior do parasita; $(B)$ várias células. (VC) vacúolo, $(\mathrm{F})$ flagelo, $(\mathrm{Ac})$ Acidocalcissomos, $(\mathrm{N})$ núcleo, $(\mathrm{k})$ DNA cinetoplasto e (BF) bolso flagelar. (A) e (C) 30000X, (B) 12000X e (D) 50000X. 
A partir da microscopia eletrônica de varredura pôde-se observar o corpo fusiforme da maioria dos promastigotas que é a forma característica também dos promastigotas típicos de Leishmania, apesar de alguns apresentarem também corpo piriforme (Figura 30 A). A presença de sulcos longitudinais por todo o corpo do parasita também foi observada. Alguns apresentavam sulcos mais profundos do que outros que, muitas vezes estavam contorcidos ao redor do corpo do parasita (Figura 30 B). Mais de $85 \%$ dos promastigotas de fase logarítmica do isolado EFSF/06/GO apresentavam flagelo atípico que é a estrutura arredondada indicada pela seta vermelha (Figura 30 A). Muitos parasitas apresentavam vários corpúsculos arredondados ou miceliformes aderidos nessa estrutura e/ou no corpo do parasita (Figura 30 C e D).
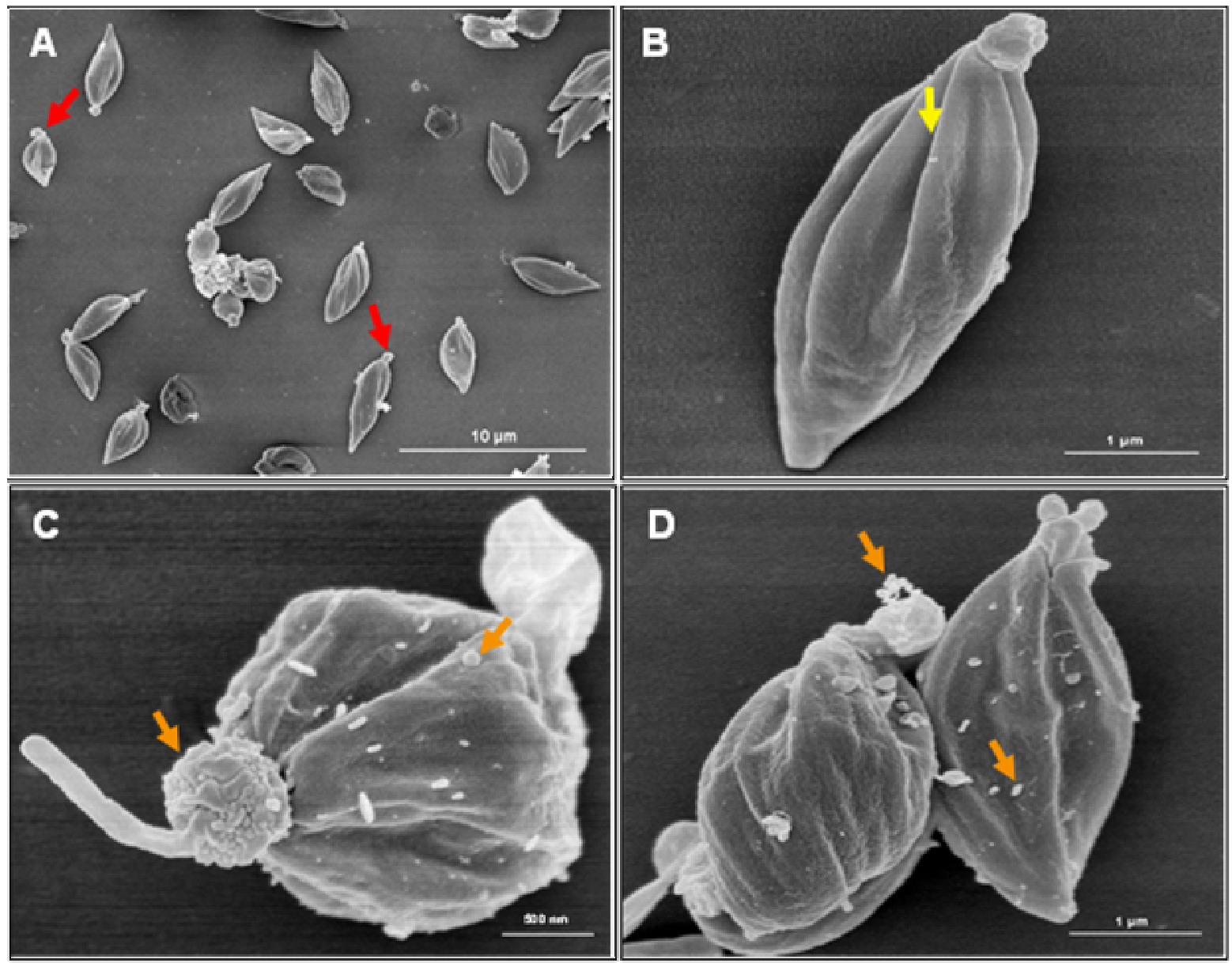

Figura 30: Microscopia eletrônica de varredura de promastigotas do isolado EFSF/06/GO. (A) corpo fusiforme ou piriforme de promastigotas de fase logarítmica com flagelo atípico (seta vermelha) $(2500 \mathrm{X})(\mathrm{B})$ presença de sulcos longitudinais (seta amarela) (17000 $X)(C)$ e (D) corpúsculos arredondados ou miceliformes (seta laranja), $30000 \times(C)$ e $19000 \times(D)$. 


\subsubsection{Imunofluorescência}

A presença de alguns antígenos normalmente encontrados no flagelo de promastigotas foi investigada no isolado EFSF/06/GO, por imunofluorescência. A marcação com anticorpos anti-tubulina confirmou a ausência ou encurtamento drástico da estrutura flagelar (Figura 31 F). Outro anticorpo utilizado foi o monoclonal SST-3 que reconhece uma glicoproteína de superfície do flagelo de $L$. (V.) braziliensis (Figura 31 I) (SILVEIRA et al., 2003). No isolado EFSF/06/GO não foi detectada a marcação específica deste anticorpo na região correspondente à estrutura arredondada, mas sim em áreas do corpo celular do parasita (Figura 31 L). Portanto, a morfologia e a reatividade com os anticorpos sugerem que a maquinaria necessária para a elongação do flagelo seja deficiente nesse isolado. 

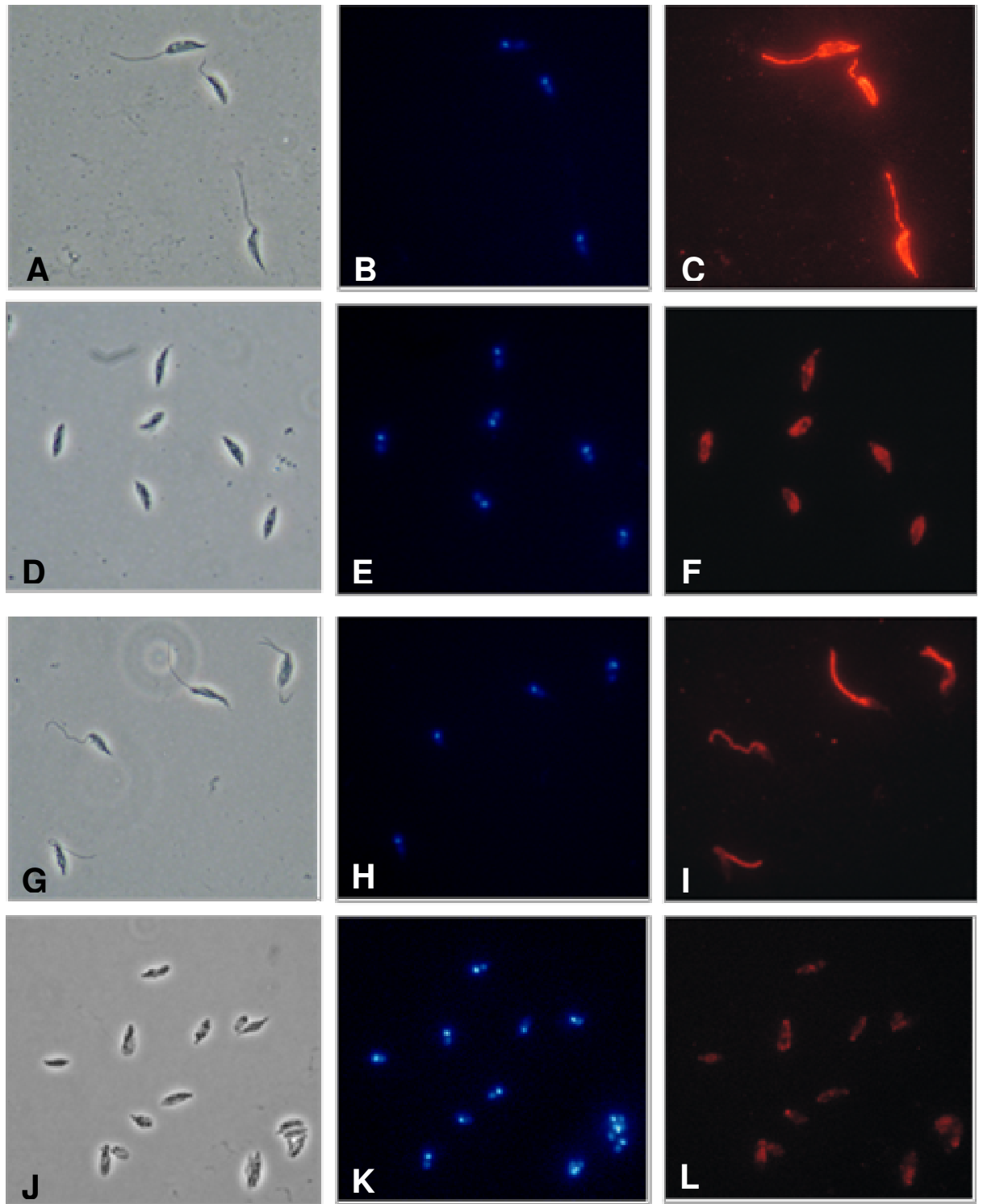

Figura 31: Imunofluorescência com promastigotas da cepa referência de $L$. (V.) braziliensis MHOM/BR/1975/M2903 e do isolado EFSF/06/GO. Contraste de fase (A, D, G e J), marcação com DAPI (B, E, H e K), com o anticorpo anti-tubulina ( $\mathrm{C}$ e F) e com o anticorpo SST-3 (I e L). As figuras $\mathrm{A}, \mathrm{B}, \mathrm{C}, \mathrm{G}, \mathrm{H}$ e I correspondem à cepa referência de L. (V.) braziliensis MHOM/BR/1975/M2903 e as figuras D, E, F, J, K e L correspondem ao isolado EFSF/06/GO. 
Discussão 


\section{Discussão}

A busca por novos compostos a serem utilizados no tratamento da leishmaniose vem sendo cada vez mais necessária. Os antimoniais são utilizados há mais de 70 anos sendo que em algumas regiões da Índia a resistência a essa droga é generalizada (GONZÁLEZ et al., 2008; SINGH et al., 2006). Os medicamentos de segunda escolha foram desenvolvidos para o tratamento de outras doenças e assim como os antimoniais são bastante tóxicos. A atividade de tamoxifeno, medicamento utilizado no tratamento do câncer de mama havia sido demonstrada em nosso laboratório contra cepas referência de Leishmania. Mas ainda não dispúnhamos de evidências de atividade em modelos de infecção experimental in vivo. Além disso, a ausência de estudos de sensibilidade de isolados brasileiros aos medicamentos comumente utilizados no tratamento da leishmaniose (anfotericina B e Glucantime ${ }^{\circledR}$ ) foram os fatores que nos levaram a desenvolver o presente trabalho.

\subsection{Isolados e sensibilidade in vitro ao tamoxifeno, anfotericina B e Glucantime ${ }^{\circledR}$}

Recebemos as culturas dos isolados já tipados como L. (L.) amazonensis e L. (V.) braziliensis. Para confirmar os dados informados e também para dispor de método rápido para verificação periódica das culturas, padronizamos um método de tipagem para o nosso laboratório utilizando como marcador molecular o gene META2 de Leishmania (RAMOS et al., 2004).

Técnicas moleculares como PCR tem-se mostrado altamente efetivas na detecção e identificação de parasitas do gênero Leishmania (DISCH et al., 2005; BERZUNZA-CRUZ et al., 2009). Através do polimorfismo de restrição com a enzima Xho I confirmamos a identificação dos isolados como $L$. (L.) amazonensis e $L$. (V.) braziliensis. Entretanto, dois isolados foram tipados como $L$. (L.) major-like (VBL/01/PA e MAB/03/PA). O método descrito por Uliana et al. (1994) e utilizado na tipagem inicial não permite distinguir entre $L$. (L.) amazonensis e $L$. (L.) major, enquanto a tipagem por RFLP do gene META 2 o faz.

L. (L.) amazonensis e L. (V.) braziliensis são espécies causadoras de sérios problemas de saúde na América do Sul (de MOURA et al., 2005). No Brasil, é grande a variedade de espécies que causam leishmaniose tegumentar americana (LTA). Sete espécies foram descritas como agentes etiológico da doença cutânea em humanos. $L$. (V.) braziliensis é a espécie mais freqüente nas Américas, com ampla distribuição, desde 
a América Central até o norte da Argentina e a mais importante nas regiões endêmicas do Brasil (CARVALHO et al., 2006; TOJAL DA SILVA et al., 2006). L. (L.) major é o agente etiológico da leishmaniose tegumentar em regiões do velho mundo (MURRAY et al., 2005). Em 1993, Momen e cols. descreveram que isolados de L. (L.) major-like foram encontrados no Novo mundo e sugeriram que algumas dessas populações deveriam ter sido importadas para as Américas.

Devido à raridade de parasitas dessa espécie nas Américas, buscamos confirmar a tipagem dos isolados VBL/01/PA e MAB/03/PA também por anticorpos monoclonais. Esses ensaios foram realizados na Universidade Federal do Pará onde foram testados vários anticorpos monoclonais permitindo a confirmação dos dois isolados como $L$. (L.) major. A presença de parasitas dessa espécie nas Américas é fato interessante e merece ser investigado, especialmente considerando que o isolado MAB/03/PA foi obtido de paciente com leishmaniose cutânea difusa, que é normalmente atribuída a infecções por L. (L.) amazonensis. Será interessante caracterizar esses parasitas com mais detalhes, por exemplo, através do sequenciamento dos espaçadores do gene ribossômico. Além disso, no caso do isolado MAB/03/PA, será importante tentar obter novo isolamento do mesmo paciente.

Posteriormente à tipagem dos isolados, iniciamos os ensaios de sensibilidade de drogas. Tentamos padronizar um método que fosse rápido, prático e que não manipulasse muito as amostras nos ensaios de sensibilidade in vitro.

Inicialmente, pensamos em avaliar a atividade das drogas através da medida da turvação do meio como é realizado em testes de sensibilidades para bactérias e como utilizado em alguns trabalhos com Leishmania (HADIGHI et al., 2006). Para isso, utilizamos dois meios (meio 199 e tampão A) porque achamos que o meio provido de cor (meio 199) pudesse interferir na leitura da turvação. Nossos resultados demonstraram que independentemente da coloração do meio, a medida da turvação não é confiável principalmente quando é utilizado um número baixo de parasitas. No controle contendo somente meio 199 ou tampão A obtiveram-se valores da D.O. maiores do que nesses meios contendo números maiores de parasitas.

Avaliamos também a medida da turvação em meio 199 contendo parasitas e incubados com diferentes concentrações de droga, nesse caso utilizando tamoxifeno. Ao contrário da contagem de células a medida da turvação aumentou quando aumentava-se a concentração da droga. Portanto, vimos que mesmo com parasitas mortos o meio continuava turvo por pelo menos $48 \mathrm{~h}$. 
Descartamos então a possibilidade de testes de atividade com drogas medindo a turvação e optamos pelo método de MTT para avaliação da viabilidade. O MTT reage com a enzima mitocondrial ativa da célula resultando em um produto colorido denominado formazan (MOSMAN, 1983). O teste de MTT utilizado no laboratório até então seguia o método descrito por Moreira et al. (1996). Esse método é bastante trabalhoso e dispendioso para avaliação de um grande número de isolados. Por isso decidimos modificar o teste de MTT tornando-o mais rápido e barato.

Como no método de Moreira et al. (1996) era necessária a lavagem dos parasitas para posteriormente adicionar o MTT em tampão A, pensamos que a presença de cor no meio pudesse reagir com o MTT interferindo nas análises. Por isso, avaliamos o crescimento de promastigotas em tampão A ou meio de Grace que são desprovidos de cor. Utilizamos tampão A adicionado de SFB para tornar o meio mais rico em nutrientes. Os diferentes meios (tampão A, tampão A suplementado com SFB e meio de Grace suplementado com SFB) contendo promastigotas foram avaliados através da contagem dos parasitas e leitura da D.O. após adição de MTT. Observamos através da contagem que somente em meio de Grace havia ocorrido multiplicação dos parasitas. Por outro lado, a leitura de D.O. após incubação com MTT em meio de Grace não teve correlação com o número de parasitas vivos. As D.Os medidas em tampão $A$ e tampão $A$ suplementado com SFB foram bastante próximas, indicando que o SFB presente no meio de Grace não era responsável pela ausência de coloração. Sendo assim, concluímos que o meio de Grace não era adequado para a realização dos testes de viabilidade por MTT.

Uma adaptação simples do protocolo de MTT foi então testada e mostrou boa correlação com a contagem de parasitas vivos, determinada em câmara de Neubauer. Nesse microteste, os parasitas são incubados em meio 199 por $24 \mathrm{~h}$ na presença de concentrações crescentes de droga, adicionando-se a seguir a solução de MTT ao próprio meio.

Para avaliarmos a sensibilidade de promastigotas à anfotericina $B$ e tamoxifeno utilizamos este microteste de MTT modificado que mostrou-se bastante eficaz para realização de ensaios de sensibilidade de promastigotas de Leishmania. É um teste extremamente rápido e barato, além de necessitar de pouca manipulação das amostras.

Já havia sido previamente demonstrado que a suscetibilidade de promastigotas de Leishmania à anfotericina $\mathrm{B}$ e tamoxifeno é semelhante à suscetibilidade de amastigotas intracelulares (SHARIEF et al., 2006; MIGUEL et al., 2007). 
A atividade das drogas foi avaliada através da determinação de $\mathrm{Cl}_{50}, \mathrm{Cl}_{90}$ e razão de resistência. A razão de resistência foi calculada devido à variação da atividade da droga (avaliada por valores de $\mathrm{Cl}_{50}$ ) observada nos testes de MTT realizados em dias diferentes com promastigotas de L. (V.) braziliensis. Por isso os testes com isolados foram sempre realizados em paralelo com a linhagem tipo.

Os valores de $\mathrm{Cl}_{50}$ determinados para anfotericina $\mathrm{B}$ variaram entre 0,04 $\pm 0,004$ $\mu \mathrm{M}(0,037 \mu \mathrm{g} / \mathrm{mL})$ e $0,12 \pm 0,014 \mu \mathrm{M}(0,11 \mu \mathrm{g} / \mathrm{mL}) \mu \mathrm{M}$ para os isolados de $L$. (V.) braziliensis e entre $0,06 \pm 0,001 \mu \mathrm{M}(0,055 \mu \mathrm{g} / \mathrm{mL})$ e $0,15 \pm 0,040 \mu \mathrm{M}(0,14 \mu \mathrm{g} / \mathrm{mL})$ para os isolados de $L$. (L.) amazonensis. $\mathrm{O}$ valor de $\mathrm{Cl}_{50}$ de um isolado de $L$. (L.) major-like foi 18 vezes maior do que o menor valor de $\mathrm{Cl}_{50}$ determinado para o isolado de $L$. (V.) braziliensis (PPS/06/BA). A sensibilidade entre os isolados foi semelhante para anfotericina $B$, sendo que somente um isolado de $L$. (L.) major-like se mostrou menos sensível a essa droga. Yardley e Croft (1997), demonstraram que 0,50 e 0,96 $\mu \mathrm{g} / \mathrm{mL}$ de anfotericina B foram suficientes para inibir em $50 \%$ o crescimento de promastigotas de isolados de $L$. (L.) major e $0,11 \pm 0,015 \mu \mathrm{g} / \mathrm{mL}$ foram suficientes para inibir em $50 \%$ o crescimento de promastigotas de $L$. (L.) donovani (MANANDHAR et al., 2008). Isolados de $L$. (L.) donovani obtidos de pacientes de uma região de alta endemicidade na Índia foram avaliados in vitro na presença de anfotericina $\mathrm{B}$. Os valores de $\mathrm{Cl}_{50}$, nesse caso, variaram entre 0,31 $\pm 0,014$ e 1,62 $\pm 0,134 \mu \mathrm{g} / \mathrm{mL}$ de anfotericina $B$ (KUMAR et al., 2009). Esses valores foram semelhantes aos determinados para os isolados brasileiros de $L$. (L.) major-like (MAB/03/PA e VBL/01/PA). Quando avaliamos os valores das $\mathrm{Cl}_{90} \mathrm{~s}$ observamos uma variação maior entre os isolados de L. (V.) braziliensis, de até 7 vezes, do que entre os isolados de L. (L.) amazonensis (2 vezes) ou L. (L.) major-like (2 vezes), mas quando avaliamos independentemente da espécie a diferença foi de até 20 vezes entre o menor e o maior valor de $\mathrm{Cl}_{90}$. De forma geral, comparando os valores de $\mathrm{Cl}_{50}$, $\mathrm{Cl}_{90}$ e RR o isolado TMB06/GO foi o mais sensível e o VBL/01/PA o mais resistente à anfotericina B.

Dando continuidade aos testes de sensibilidade de promastigotas, avaliamos a atividade in vitro de tamoxifeno contra os isolados.

Foi demonstrado que tamoxifeno apresenta efeito citotóxico para vários tipos de células neoplásicas (PONTIGGIA et al., 2008) e efeito in vitro também foi mostrado para Candida albicans (BEGGS, 1996). Até então, Miguel et al. (2007), havia demonstrado que tamoxifeno era ativo contra cepas referência de $L$. braziliensis, $L$. amazonensis, $L$. chagasi, L. donovani e L. major in vitro. 
A atividade de tamoxifeno foi avaliada contra isolados de campo através dos valores de $\mathrm{Cl}_{50}, \mathrm{Cl}_{90}$ e razão de resistência. Os resultados apresentados na Tabela 4 foram semelhantes aos descritos por Miguel et al., 2007. Nesse caso, os valores de $\mathrm{Cl}_{50}$ variaram entre 9,3 \pm 0,3 e 19,9 \pm 0,3 $\mu \mathrm{M}$ para as cepas referência de $L$. major e $L$. donovani, respectivamente.

No presente trabalho, o maior valor de $\mathrm{Cl}_{50}$ foi determinado para o isolado de $L$. (L.) amazonensis (EGS/04/GO) que foi de 14,8 \pm 0,99 $\mu \mathrm{M}$ de tamoxifeno, portanto, menor do que os anteriores observados.

Diferentemente dos resultados obtidos com anfotericina $B$, a sensibilidade ao tamoxifeno foi semelhante entre os isolados, variando de até 2 vezes entre o menor e o maior valor para a $\mathrm{Cl}_{50}, \mathrm{Cl}_{90}$ e razão de resistência. Quanto à sensibilidade de amastigotas, já havia sido mostrado por Miguel et al. (2007) com a cepa referência de $L$. (L.) amazonensis que os valores de $\mathrm{Cl}_{50}$ verificados para as duas formas do parasita foram próximos, de 11,1 e 16,4 $\mu \mathrm{M}$ de tamoxifeno. Neste trabalho, avaliamos a atividade de tamoxifeno contra amastigotas de alguns isolados de Leishmania incubando os parasitas com a droga por um período de $48 \mathrm{~h}$ como foi avaliado por Miguel et al. (2007) e por um período maior, de 6 dias como foi realizado com Sbv ${ }^{v}$. Confirmamos através dos valores de $\mathrm{Cl}_{50}$ que a sensibilidade de amastigotas e promatigotas ao tamoxifeno foi similar, diferentemente da sensibilidade ao antimônio que é de até 100 vezes maior para amastigotas (AZEREDO-COUTINHO et al., 2007). Vimos também que um período menor, de até $48 \mathrm{~h}$, é suficiente para a atividade de tamoxifeno contra amastigotas.

Apesar dos relatos na literatura de que promastigotas de Leishmania são menos sensíveis ao antimônio pentavalente do que amastigotas, existem muitos trabalhos que comparam a sensibilidade de isolados a esse fármaco utilizando essa forma do parasita. Sendo assim, avaliamos primeiramente a atividade de promastigotas de $L$. (V.) braziliensis ao Glucantime ${ }^{\circledR}$ através do microteste de MTT modificado. Vimos que concentrações de $32,4 \mathrm{mg} / \mathrm{mL}$ de antimônio pentavalente não foram suficientes para inibir o crescimento de promastigotas em $24 \mathrm{~h}$. $\mathrm{A} \mathrm{Cl}_{50}$ de promastigotas de L. (V.) braziliensis determinada por Grogl et al. (1992) foi de 0,2 a 4,1 $\mathrm{mg} / \mathrm{mL}$ de $\mathrm{Sb}^{v}$ após $24 \mathrm{~h}$ de incubação. Azeredo-Coutinho et al. (2007) demonstraram que promastigotas de isolados de $L$. (V.) braziliensis obtidos de pacientes no Rio de Janeiro apresentaram valores de $\mathrm{Cl}_{50}$ entre 0,8 e 9,5 mg/mL de antimônio pentavalente após período de incubação de $72 \mathrm{~h}$. Nesse mesmo estudo, outras espécies como L. (L.) tropica, L. (L.) mexicana, L. (L.) amazonensis, L. (V.) panamensis e L. (V.) guyanensis também foram avaliadas e os 
valores de $\mathrm{Cl}_{50}$ variaram entre 10 e $60 \mathrm{mg} / \mathrm{mL}$ de antimônio pentavalente. Deste modo, o valor de $\mathrm{Cl}_{50}$ para $L$. (L.) mexicana foi até 6 vezes maior do que o maior valor descrito para L. (V.) braziliensis.

Avaliamos vários lotes de Glucantime ${ }^{\circledR}$ testando as mesmas concentrações de droga, 16,2 e $32,4 \mathrm{mg} / \mathrm{mL}$ de antimônio pentavalente. Todos os lotes avaliados apresentaram o mesmo comportamento, logo, resolvemos avaliar a atividade do Glucantime ${ }^{\circledR}$ através da contagem dos parasitas após $24,48,72$ e 120 h de incubação com a droga. Observamos que a atividade do Glucantime ${ }^{\circledR}$ é dose/tempo-dependente, com atividade apreciável detectada apenas após longos períodos de incubação. Sendo assim, este método não foi adequado para avaliar a sensibilidade por ser um teste muito longo e trabalhoso, além de existir a crítica de que o antimônio tem que ser metabolizado pelo macrófago e convertido em antimônio trivalente que é a forma ativa contra o parasita (OUELLETTE et al., 2004).

Posteriormente às análises de sensibilidade de promastigotas a antimônio pentavalente e conclusão de que esta forma do parasita não foi adequada para avaliação in vitro a curto prazo na presença dessa droga, buscamos então avaliar a atividade contra amastigotas intracelulares.

Visto que existem poucos relatos de interação in vitro de macrófagos com parasitas do subgênero Viannia, avaliamos primeiramente a taxa de infecção de quatro tipos diferentes de macrófagos (J774.A1, THP-1, macrófagos de peritônio e macrófagos de medula) por promastigotas de fase estacionária de $L$. (V.) braziliensis. Promastigotas de fase estacionária são mais infectivos do que os de fase logarítmica. Isto foi mostrado com promastigotas de L. (L.) donovani, L. (L.) tropica, L. (L.) major e L. (L.) mexicana (ZAKAl et al., 1998). A infecção por L. (V.) braziliensis é caracterizada por apresentar vacúolos pequenos com poucos amastigotas por vacúolo. Dos macrófagos utilizados neste trabalho, o macrófago de medula foi o que apresentou maiores taxas de infecção. de $84 \%$. Foi mostrado por Maia et al. (2007) que a taxa de infecção de macrófagos de medula por $L$. (L.) infantum é maior do que para macrófagos de peritônio, macrófagos derivado de sangue periférico humano ou macrófagos diferenciados de linhagens celulares U-937 e DH82.

Além de apresentar a maior taxa de infecção os macrófagos de medula apresentaram também citoplasma expandido o que facilitou a contagem dos parasitas. Já que iríamos utilizar um número elevado de macrófagos, outro benefício foi o maior 
rendimento por animal de macrófagos de medula em comparação com macrófagos de peritônio de camundongos BALB/c.

Com base nos resultados discutidos acima com infecção de macrófagos de medula por $L$. (V.) braziliensis, decidimos utilizar esse modelo de infecção para avaliação de antimônio contra amastigotas intracelulares.

Os ensaios de padronização de infecção de macrófagos foram realizados com a cepa referência de L. (V.) braziliensis MHOM/BR/1975/M2903. Quando utilizamos os isolados para ensaios de sensibilidade observamos variações na taxa de infecção de 20 a $85 \%$ para os isolados de L. (V.) braziliensis, 50 a $100 \%$ para os isolados de $L$. (L) amazonensis e de 58 e $68 \%$ para os isolados de L. (L.) major-like. Além da porcentagem de infecção, o número de amastigotas por macrófago também foi maior para os isolados de $L$. $(L)$ amazonensis, com média de 11 amastigotas/macrófago. Segundo Gomes et al. (2003) a espécie de Leishmania pode influenciar na taxa de infecção. Geralmente, espécies de $L$. $(L)$ amazonensis são mais virulentas e a infectividade in vitro é maior do que de espécies de $L$. (V.) braziliensis.

Antes de iniciarmos os ensaios de atividade contra amastigotas, avaliamos a citotoxicidade ao Glucantime ${ }^{\circledR}$ e tamoxifeno. O valor da $\mathrm{Cl}_{50}$ para as duas drogas avaliadas foi maior do que a dose máxima utilizada nos ensaios de sensibilidade. Para tamoxifeno foi maior do que $20 \mu \mathrm{M}$ e para antimônio maior do que $810 \mu \mathrm{g} / \mathrm{mL}$. Portanto, as doses utilizadas não foram tóxicas para o macrófago.

Em todos os experimentos foi incluída a cepa referência testada em paralelo com os isolados e os resultados foram avaliados através da $\mathrm{Cl}_{50}, \mathrm{Cl}_{90}$ e RR. A sensibilidade ao antimônio variou até 8 vezes entre o menor e o maior valor de $\mathrm{Cl}_{50}$ e até 14 e 5 vezes entre o menor e o maior valor de $\mathrm{Cl}_{90}$ e $\mathrm{RR}$, respectivamente. Os isolados de $L$. (V.) braziliensis apresentaram maior sensibilidade ao antimônio do que os isolados de $L$. $(L)$ amazonensis e de L. (L.) major-like. Segundo Allen e Neal (1989) apud Yardley et al. (2006), cepas referência de L. (V.) braziliensis, L. (V.) guyanensis e L. (V.) panamensis foram de 3 a 5 vezes mais sensíveis ao $\mathrm{Sb}^{v}$ (média de $\mathrm{Cl}_{50}$ menor que $5 \mu \mathrm{g} / \mathrm{mL}$ ) do que $L$. (L.) major, L. (L.) tropica e L. (L.) mexicana. Das cepas provenientes dos pacientes que retornaram para o tratamento e apresentaram cura clínica, os valores de $\mathrm{Cl}_{50}$ variaram entre $29,1 \pm 4,6$ e 146,0 $\pm 5,0 \mu \mathrm{g} / \mathrm{mL}$ de $\mathrm{Sb}^{v}$, os valores de $\mathrm{Cl}_{90}$ entre 65,6 e $299,7 \mu \mathrm{g} / \mathrm{mL}$ de $\mathrm{Sb}^{\vee}$ e razão de resistência entre $0,85 \pm 0,25$ e 2,67 $\pm 0,35$. Neste caso, os valores menores de $\mathrm{Cl}_{50}, \mathrm{Cl}_{90}$ e razão de resistência referem-se ao isolado de $L$. (V.) braziliensis (TMB/06/GO) e os valores maiores de $\mathrm{Cl}_{50}$ e razão de resistência ao isolado de $L$. (L) 
amazonensis (JSC/06/PA) (Tabela 8). Nos trabalhos disponíveis na literatura, observamos que havia uma grande variação nos valores de $\mathrm{Cl}_{50}$ determinados para cepas resistentes ou sensíveis ao antimônio. Em 1984, foi mostrado por Neal e Croft que uma maior proporção de amastigotas/macrófago pode influenciar na $\mathrm{Cl}_{50}$ de $\mathrm{Sb}^{\mathrm{v}}$. Isolados de $L$. (L.) donovani de uma região de alta resistência na Índia mostraram média da $C_{50}$ significativamente maior $\left(15,81 \pm 2,5 \mu \mathrm{g} / \mathrm{mL}\right.$ de $\left.\mathrm{Sb}^{\vee}\right)$ quando comparado com iso lados de uma região de baixa resistência $\left(5,46 \pm 3,69 \mu \mathrm{g} / \mathrm{mL}\right.$ de $\mathrm{Sb}^{\vee}$ ) (KUMAR et al., 2009). Sendo assim, a média dos valores de $\mathrm{Cl}_{50}$ descritos acima foi menor do que o menor valor de $\mathrm{Cl}_{50}$ determinado para os isolados brasileiros, que no nosso trabalho foi de $18,5 \pm 4,20$ $\mu \mathrm{g} / \mathrm{mL}$ de $\mathrm{Sb}^{\mathrm{V}}$. Neste caso, todos os isolados avaliados em nosso trabalho poderiam ser classificados como resistentes in vitro ao antimônio.

Hadighi et al. (2006), testando isolados de L. (L.) major e L. (L.) tropica, observaram que isolados de pacientes que não apresentaram cura clínica após tratamento com Sbv tiveram $\mathrm{Cl}_{50}$ maior do que $13,2 \mu \mathrm{g} / \mathrm{mL} \mathrm{Sb}$. Uma correlação entre a resistência in vitro ao $\mathrm{Sb}^{v}$ e o tratamento clínico tem sido demonstrada com $L$. (L.) donovani na Índia (LIRA et al., 1999), mas não no Sudão (ABDO et al., 2003). Com isolados de L. (V.) braziliensis e L. (V.) panamensis da Guatemala e Peru também foi observada essa correlação (GROGL et al., 1992).

Rojas et al. (2006) consideraram cepas do subgênero Viannia resistentes aquelas que tiveram $\mathrm{Cl}_{50}$ maior do que $128 \mu \mathrm{g} / \mathrm{mL}$ de $\mathrm{Sb}^{\mathrm{V}}$. Segundo esse critério, dois de nossos isolados (JSC/06/PA e MAB/03/PA) foram resistentes ao $\mathrm{Sb}^{v}$ porque apresentaram $\mathrm{Cl}_{50}$ maior do que $128 \mu \mathrm{g} / \mathrm{mL}$ de $\mathrm{Sb}^{\mathrm{V}}$.

Yardley et al. (2006) avaliaram a sensibilidade in vitro de 37 isolados de pacientes do Peru ao $\mathrm{Sb}^{v}$ através da razão de resistência e compararam com a resposta desses pacientes ao tratamento com $\mathrm{Sb}^{v}$. Dos 37 isolados avaliados, 26 eram de L. (V.) braziliensis, 5 de L. (V.) guyanensis, 4 de L. (V.) lainsoni, 1 de L. (V.) peruviana e 1 de $L$. (L.) amazonensis. Dos isolados de $L$. (V.) braziliensis avaliados, 22 foram resistentes ao $\mathrm{Sb}^{v}$ in vitro, apenas 4 isolados foram sensíveis ao $\mathrm{Sb}^{v}$, sendo que 2 correspondiam aos pacientes que não responderam ao tratamento. Dos 5 isolados de $L$. (V.) guyanensis, 2 foram sensíveis e dos 4 isolados de $L$. (V.) lainsoni, 1 foi sensível ao $\mathrm{Sb}^{\mathrm{v}}$, mas todos os pacientes responderam ao tratamento. $O$ isolado de $L$. (L.) amazonensis foi sensível ao $\mathrm{Sb}^{v}$ in vitro, mas o paciente não foi avaliado. Segundo Yardley et al. (2006) uma cepa resistente ao antimônio deve apresentar o valor da razão de resistência maior ou igual a 
5. Sendo assim e de acordo com esse critério, nenhum dos isolados avaliados em nosso trabalho apresentaram resistência in vitro ao antimônio.

$\mathrm{Na}$ América Latina, relatos da eficácia do tratamento da leishmaniose cutânea com antimonial têm revelado efeitos contrastantes com $7 \%$ de falha terapêutica na Bolívia (BERMUDEZ et al., 2006), 16\% no Brasil (OLIVEIRA-NETO et al., 1997) e 39\% na Colômbia (PALACIOS et al., 2001).

$\mathrm{Na}$ literatura encontramos vários trabalhos testando a sensibilidade in vitro de isolados de áreas endêmicas do Velho Mundo e Américas, sendo que apenas um único trabalho de sensibilidade ao antimônio foi realizado com isolados brasileiros. Nesse trabalho, Azeredo-Coutinho et al. (2007) compararam a sensibilidade in vitro de promastigotas e amastigotas de isolados de pacientes do Rio de Janeiro ao Glucantime ${ }^{\circledR}$. A atividade dos isolados de $L$. (V.) braziliensis foi comparada com a atividade de outras espécies de Leishmania e com a resposta dos pacientes ao tratamento. Amastigotas de isolados brasileiros $(n=5)$ de $L$. (V.) braziliensis revelaram valores de $\mathrm{Cl}_{50}$ entre 19 e 55 $\mu \mathrm{g} / \mathrm{mL}$ de $\mathrm{Sb}^{v}$ após $72 \mathrm{~h}$ de incubação, sendo que os isolados obtidos de pacientes que responderam ao tratamento apresentaram $\mathrm{Cl}_{50}$ significativamente menores e aqueles que não responderam ao tratamento apresentaram $\mathrm{Cl}_{50}$ maiores (AZEREDO-COUTINHO et al., 2007).

Comparando nossos resultados com os dados descritos acima, os valores de $\mathrm{Cl}_{50}$ obtidos para os isolados do Rio de Janeiro são da mesma ordem de grandeza que os valores de $\mathrm{Cl}_{50}$ encontrados em nosso trabalho (Tabela 8).

$\mathrm{O}$ isolado MAB/03/PA obtido do paciente que apresenta a forma difusa e não respondeu a nenhum tratamento, foi também o que apresentou maior valor da $\mathrm{Cl}_{90}$, de $955,4 \mu \mathrm{g} / \mathrm{mL}$ de $\mathrm{Sb}^{v}$. O valor da $\mathrm{Cl}_{50}$ determinado para esse isolado foi um dos maiores, de 138,3 $\pm 19,8 \mu \mathrm{g} / \mathrm{mL}$ (Tabela 8 ). Este paciente já foi submetido a vários cursos de tratamento com antimoniais, anfotericina B e imunoterapia. Após o tratamento, verificouse melhora clínica temporária seguida sempre de recrudescência após alguns meses (Ledice Pereira e Miriam Dorta, comunicação pessoal). Apesar dos valores elevados de sensibilidade in vitro, sabe-se que essa forma clínica de leishmaniose é também decorrência de características genéticas anérgicas do hospedeiro.

De todos os isolados testados, além do MAB/03/PA, 2 foram obtidos de pacientes que precisaram de 2 cursos de tratamento com Glucantime (BES/06/GO e UAF/06/TO) para que houvesse resposta clínica. Entretanto, os valores de $\mathrm{Cl}_{50}$ determinados para esses isolados não foram os maiores. 
Dos pacientes que retornaram após o tratamento, mais de $90 \%$ apresentaram cura clínica que foi avaliada através da cicatrização da lesão até 3 meses após término do tratamento e com acompanhamento de até um ano após o tratamento com Glucantime ${ }^{\circledR}$. Assim, não obtivemos evidências de resistência in vitro ao antimonial pentavalente. Por outro lado, considerando-se o pequeno número de amostras avaliadas, esses dados não nos permitem concluir que tal resistência não exista no campo.

Tabela 8: Comparação da sensibilidade in vitro dos isolados de Leishmania ao antimônio com a resposta clínica dos pacientes ao tratamento.

\begin{tabular}{|c|c|c|c|c|c|}
\hline $\begin{array}{c}\text { Paciente/ano/ } \\
\text { local }\end{array}$ & $\begin{array}{l}\text { Tratamento } \\
\text { posterior }^{\mathrm{a}}\end{array}$ & $\begin{array}{c}\mathrm{Cl}_{50} \pm \mathrm{DP} \\
\mathrm{Sb}^{\mathrm{v}} \mu \mathrm{g} / \mathrm{mL}\end{array}$ & $\begin{array}{c}\mathrm{Cl}_{90} \\
\mathrm{Sb}^{\mathrm{v}} \mu \mathrm{g} / \mathrm{mL}\end{array}$ & $\mathbf{R R}^{\mathrm{b}}$ & Evoluçãoc $^{c}$ \\
\hline $\mathrm{BES} / 06 / \mathrm{GO}^{L b}$ & $\begin{array}{c}\text { Glucantime } \\
\text { (>18 g AM), } \\
\text { Anfotericina B }\end{array}$ & $52,4 \pm 5,3$ & 203,3 & $1,50 \pm 0,26$ & Cura Clínica \\
\hline $\mathrm{EFSF} / 06 / \mathrm{GO}^{L b}$ & $\begin{array}{c}\text { Glucantime } \\
\text { (18 g AM) }\end{array}$ & $55,0 \pm 12,2$ & 150,2 & $1,60 \pm 0,67$ & Cura Clínica \\
\hline $\mathrm{GDL} / 06 / \mathrm{GO}^{L b}$ & $\begin{array}{c}\text { Glucantime } \\
\text { (18 g AM) }\end{array}$ & $31,1 \pm 1,50$ & 96,0 & $0,90 \pm 0,06$ & Cura Clínica \\
\hline $\mathrm{HPV} / 06 / \mathrm{TO}^{L b}$ & $\begin{array}{l}\text { Glucantime } \\
\text { (18 g AM) }\end{array}$ & $58,0 \pm 13,8$ & 299,7 & $1,70 \pm 0,76$ & Cura Clínica \\
\hline $\mathrm{IMG} / 03 / \mathrm{GO}^{L b}$ & $\begin{array}{l}\text { Glucantime } \\
\text { (18 g AM) }\end{array}$ & $58,8 \pm 5,40$ & 175,8 & $1,70 \pm 0,27$ & Cura Clínica \\
\hline $\mathrm{PPS} / 06 / \mathrm{BA}^{L b}$ & NR & $18,5 \pm 4,20$ & 96,0 & $0,54 \pm 0,23$ & NR \\
\hline $\mathrm{RPL} / 05 / \mathrm{GF}^{L b}$ & $\begin{array}{l}\text { Glucantime } \\
\text { (18 g AM) }\end{array}$ & $59,8 \pm 3,20$ & 136,2 & $1,70 \pm 0,14$ & Cura Clínica \\
\hline $\mathrm{TMB} / 06 / \mathrm{GO}^{L b}$ & $\begin{array}{l}\text { Glucantime } \\
\text { (18 g AM) }\end{array}$ & $29,1 \pm 4,60$ & 65,6 & $0,85 \pm 0,25$ & Cura Clínica \\
\hline $\mathrm{UAF} / 06 / \mathrm{TO}^{L b}$ & $\begin{array}{l}\text { Glucantime } \\
(>18 \mathrm{~g})\end{array}$ & $31,6 \pm 9,70$ & 148,7 & $0,92 \pm 0,54$ & Cura Clínica \\
\hline $\mathrm{WSS} / 05 / \mathrm{GO}^{L b}$ & NR & $44,8 \pm 2,30$ & 124,8 & $1,31 \pm 0,09$ & NR \\
\hline $\mathrm{EGS} / 04 / \mathrm{GO}^{\mathrm{La}}$ & NR & $112,4 \pm 3,2$ & 238,7 & $2,05 \pm 0,30$ & NR \\
\hline $\mathrm{JRS} / 01 / \mathrm{GO}^{L a}$ & $\begin{array}{c}\text { Glucantime } \\
\text { (18 g AM) }\end{array}$ & $112,2 \pm 3,6$ & 197,7 & $2,05 \pm 0,28$ & Cura Clínica \\
\hline $\mathrm{JSC} / 06 / \mathrm{PA}^{\mathrm{La}}$ & $\begin{array}{l}\text { Glucantime } \\
\text { (18 g AM) }\end{array}$ & $146,0 \pm 5,0$ & 296,8 & $2,67 \pm 0,35$ & Cura Clínica \\
\hline $\mathrm{MAB} / 03 / \mathrm{PA}^{\mathrm{Lm}}$ & $\begin{array}{c}\text { Anfotericina B } \\
\text { liposomal }\end{array}$ & $138,3 \pm 19,8$ & 955,4 & - & Sem melhora \\
\hline VBL/01/PA ${ }^{L m}$ & $\begin{array}{l}\text { Glucantime } \\
\text { (18 g AM) }\end{array}$ & $62,11 \pm 7,16$ & 341,6 & - & NR \\
\hline
\end{tabular}

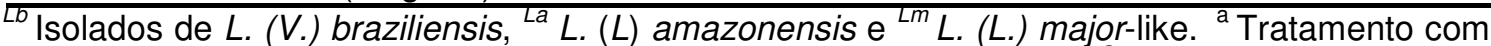
$\mathrm{AM}=$ Antimoniato de meglumine $\left(18 \mathrm{~g}=60\right.$ ampolas de Glucantime $\left.{ }^{\circledR}\right)$ após 0 isolamento da cepa; ${ }^{\text {b }} \mathrm{RR}=$ Razão de resistência (razão entre o valor de $\mathrm{Cl}_{50}$ do isolado e da cepa referência), (-) não calculado; ${ }^{c} N R=$ não retornou. 


\subsection{Eficácia do tamoxifeno no tratamento de infecções por $L$. (V.) braziliensis}

Havia sido anteriormente demonstrado que tamoxifeno era ativo contra promastigotas e amastigotas intracelulares de cepas referência de Leishmania (MIGUEL et al., 2007). A avaliação da atividade de tamoxifeno contra isolados de campo seria importante para validar os achados obtidos com cepas referência, muitas vezes mantidas em cultivo em laboratórios há muitos anos. Assim, nesse trabalho confirmamos a atividade homogênea de tamoxifeno contra isolados obtidos recentemente de pacientes com leishmaniose.

Miguel et al. (2008) mostraram que doses de $20 \mathrm{mg} / \mathrm{Kg} / \mathrm{dia}$ de tamoxifeno administradas por 15 dias consecutivos por via intraperitonial resultaram em redução da carga parasitária e tamanho da lesão de camundongos BALB/c infectados com $L$. (L.) amazonensis. Um dos objetivos de nosso trabalho foi avaliar se tamoxifeno era eficaz também no tratamento de infecções causadas por $L$. (V.) braziliensis em modelo experimental murino.

A espécie L. (V.) braziliensis é difícil de ser isolada, cultivada e mantida em laboratório (ANDRADE et al., 2005). A adição de urina humana masculina estéril no meio de cultura suplementado com soro fetal bovino resulta em maior sucesso no cultivo desses parasitas (HOWARD et al., 1991). Segundo Sampaio et al. (2002) a urina humana é utilizada no meio como estimulante da divisão celular e facilita o cultivo de células primárias de tecido animal infectado.

Um outro problema no estudo de isolados de $L$. (V.) braziliensis tem sido a dificuldade de estabelecer modelos experimentais adequados para infecção in vivo. Cepas de L. (V.) braziliensis geralmente não são infectantes ou causam infecção assintomática em camundongos. Recentemente, um modelo experimental de leishmaniose cutânea americana foi estabelecido utilizando camundongos BALB/c. Nesse modelo, o inóculo de $10^{5}$ parasitas foi realizado por via intradérmica na orelha de camundongos verificando-se indução de lesão de curso auto-limitado (de MOURA et al., 2005).

Visando implantar esse modelo experimental de infecção por L. (V.) braziliensis em nosso laboratório, utilizamos dois diferentes isolados e três diferentes sítios de infecção em camundongos BALB/c. Um desses isolados, MHOM/BR/01/BA, havia sido utilizado com sucesso na infecção experimental de camundongo BALB/c. A espessura da orelha e da pata e diâmetro da cauda foram medidos semanalmente durante 12 
semanas. Na pata foi observado um pequeno edema que se iniciou na quinta semana para os dois isolados avaliados (MHOM/BR/01/BA e UAF/06/TO). Na cauda não se obteve lesões detectáveis. Nossos resultados de infecção na orelha foram semelhantes aos demonstrados por de Moura et al., 2005, que observaram que o inóculo de $10^{5}$ promastigotas de $L$. (V.) braziliensis induziu lesão na orelha na maioria dos camundongos infectados e a lesão atingiu tamanho máximo de $1 \mathrm{~mm}$ na quinta semana. A lesão na orelha causada pelo isolado UAF/06/TO atingiu tamanho máximo de 0,8 $\mathrm{mm}$ na décima semana.

Considerando as características da lesão e da evolução clínica, decidimos utilizar o modelo de infecção na orelha com o isolado MHOM/BR/01/BA para avaliar a eficácia do tratamento com tamoxifeno. Como esse é um modelo de cura espontânea, buscamos observar se haveria redução ou ausência de lesão nos animais tratados no momento em que a doença atingia o pico de manifestações clínicas no grupo controle.

A lesão foi avaliada também através do aspecto histopatológico que foi analisado quando as lesões já estavam curadas. Neste caso, observamos claramente uma reação inflamatória no local do inóculo, mas não foi possível quantificar os amastigotas no tecido devido ao reduzido número de parasitas nas lesões que foram revelados pela existência de vacúolos pequenos contendo pouco amastigotas por vacúolo. Sendo assim, este método não foi adequado para avaliar a atividade de drogas em infecções causadas por L. (V.) braziliensis, já que a lesão possuía redução acentuada de parasitas.

Os esquemas de doses utilizados não levaram a alterações no peso dos camundongos. Além do tamoxifeno, utilizamos como controles positivos do tratamento, anfotericina B e Glucantime ${ }^{\circledR}$. A dose preconizada pela OMS para o tratamento da leishmaniose cutânea com $\mathrm{Sb}^{v}$ é de $20 \mathrm{mg} / \mathrm{Kg} /$ dia por 20-28 dias. Infusões intravenosas de 15 a $20 \mathrm{mg} / \mathrm{Kg}$ de anfotericina $B$ em dias alternados foram administradas em pacientes necessitando de hospitalização prolongada (SUNDAR et al., 2000). Em camundongos foi observada toxicidade aguda após receberem doses acima de $1 \mathrm{mg} / \mathrm{Kg}$ de anfotericina B (YARDLEY e CROFT, 1997). Neste trabalho, utilizamos doses de 0,5 $\mathrm{mg} / \mathrm{Kg}$ dessa droga.

A administração das drogas foi realizada por via intraperitonial com citrato de tamoxifeno $(10,20$ ou $30 \mathrm{mg} / \mathrm{Kg} / \mathrm{dia})$ por 15 dias consecutivos, Glucantime ${ }^{\circledR}$ (20 $\mathrm{mg} / \mathrm{Kg} / \mathrm{dia})$ por 15 dias consecutivos ou anfotericina B $(0,5 \mathrm{mg} / \mathrm{Kg} / \mathrm{dia})$ por 6 dias alternados. O grupo controle recebeu somente salina que foi utilizado como diluente das drogas. O tratamento com tamoxifeno diluído em etanol e $10 \%$ de glicerol também foi 
avaliado por via tópica. Como glicerol é bastante utilizado em cosméticos como hidratante cutâneo, adicionamos na formulação para facilitar a penetração da droga. A orelha dos camundongos apresentou edema e eritema tanto no grupo tratado com tamoxifeno tópico quanto no grupo que recebeu somente o veículo. Depois de observada essa reação provocada pelo veículo, optamos por avaliar a atividade de tamoxifeno somente por via intraperitonial.

A eficácia das drogas foi avaliada através da medida da lesão e da carga parasitária no tecido infectado. Nos 3 experimentos realizados, escolhemos a semana 6 para avaliação da medida da lesão por ser o período em que a lesão atingiu tamanho máximo no grupo controle. Doses de 20 ou $30 \mathrm{mg} / \mathrm{Kg} / \mathrm{dia}$ de tamoxifeno foram igualmente eficazes, reduzindo em até $50 \%$ o tamanho da lesão e induzindo diminuição significativa do número de parasitas na lesão quando comparado com o grupo controle não tratado. Quanto aos medicamentos comumente utilizados no tratamento da leishmaniose, o tamanho da lesão foi maior no grupo tratado com Glucantime ${ }^{\circledR}$ em relação ao grupo tratado com anfotericina $B$, porém menos parasitas foram encontrados nas lesões do grupo tratado com Glucantime ${ }^{\circledR}$. O tratamento com antimoniato de meglumina não leva a cura estéril, como observado previamente em modelo animal assim como se observou em humanos (VERGEL et al., 2006).

O tratamento com tamoxifeno em humanos é bem tolerado e apresenta poucos efeitos colaterais a curto prazo. Sendo indicado para o tratamento e prevenção do câncer de mama, é usado continuamente por um período de 5 anos com doses diárias de 20 a $40 \mathrm{mg}$ (VOGEL et al., 2006). Em consequência do uso prolongado pode induzir carcinoma endometrial (JORDAN, 2003). Em modelo experimental foi demonstrado efeito carcinogênico e mutagênico in vitro e in vivo e indução de câncer de fígado em ratos após administração a longo prazo (ZITO, 1994; WILLIAMS et al., 1997). Em nosso trabalho, tamoxifeno foi efetivo em um período curto de tratamento. Foi relatado também que este esquema de tratamento não alterou o peso ou histopatologia uterina de camundongos BALB/c e foi igualmente eficaz em hamsters fêmeas e machos (MIGUEL et al., 2008, 2009). Doses diárias de 10 a 80 mg/dia de tamoxifeno por 3 semanas tem sido bem tolerado e parece controlar distúrbio bipolar avaliado em 29 pacientes de ambos os sexos (ZARATE et al., 2007). Estes relatos indicam que tamoxifeno pode ser administrado seguramente tanto em mulheres como em homens.

Além dos sérios efeitos colaterais e casos de resistência ao antimônio, existe também o problema da administração dos medicamentos, que para anfotericina B ou 
Glucantime ${ }^{\circledR}$ devem ser por via parenteral e por períodos prolongados necessitando de hospitalização. Muitas vezes os pacientes não completam todo o curso do tratamento. Outra vantagem para estender as pesquisas com tamoxifeno é o custo do medicamento, tamoxifeno é consideravelmente mais barato do que os medicamentos utilizados no tratamento da leishmaniose. Tamoxifeno é 2 vezes mais barato do que Glucantime ${ }^{\circledR}, 6$ vezes mais barato do que anfotericina $B$ e quase 50 vezes mais barato do que anfotericina B lipossomal.

\subsection{Morfologia do isolado EFSF/06/GO}

Em paralelo com os objetivos propostos, caracterizamos morfologicamente 0 isolado EFSF/06/GO que nos chamou a atenção por apresentar morfologia distinta. Os promastigotas eram pequenos, pouco móveis, apresentavam flagelo muito curto ou não visível. Apesar de sabido que o isolado foi obtido de uma paciente com lesão cutânea localizada e ter sido identificado como $L$. (V.) braziliensis, inicialmente questionamos se realmente era um parasita desse gênero. Após confirmação por PCR e ensaios com anticorpos monoclonais, decidimos seqüenciar as regiões ITS1, 5.8S e ITS2 (espaçadores internos transcritos) do gene ribossômico de tripanossomatídeos. Estes marcadores moleculares são muito utilizados na identificação de tripanossomatideos podendo determinar relações filogenéticas e também colaborar na identificação de um determinado isolado. As regiões espaçadoras internas conhecidas como ITS, evoluem rapidamente, apresentando alto polimorfismo, e sendo desta forma, de grande interesse nos estudos filogenéticos de gêneros, espécies e populações. A alta similaridade da sequência de nucleotídeos das regiões ITS1, 5.8S e ITS2 do isolado EFSF/06/GO com as sequências de $L$. (V.) braziliensis sugeriu a confirmação do isolado como L. (V.) braziliensis.

Como formas desprovidas de flagelo (amastigotas-like) podem ser obtidas em algumas espécies por cultura em temperaturas mais elevadas, testamos se uma redução na temperatura de cultivo teria algum efeito na morfologia desse isolado. Mas, mesmo a $22{ }^{\circ} \mathrm{C}$, a cultura manteve as características atípicas observadas a $25^{\circ} \mathrm{C}$.

Avaliamos também a infecção in vitro e in vivo desse isolado que apresentou padrões típicos de infecções causadas por $L$. (V.) braziliensis. Observamos na infecção de macrófagos a existência de vacúolos pequenos contendo poucos amastigotas por vacúolo. Em camundongos infectados na orelha, o aparecimento e cura da lesão foram 
rápidos, sendo que o edema foi detectado a partir da terceira semana e na décima semana todos os animais estavam clinicamente curados. O exame histopatológico da orelha revelou a reação inflamatória no local do inóculo, mas não foi possível identificar amastigotas no tecido por microscopia óptica.

Durante a caracterização morfológica do isolado EFSF/06/GO surgiu a dúvida se quando a cepa foi isolada do paciente apresentava essa mesma morfologia. Então avaliamos a morfologia do isolado assim que foi obtido do paciente e mais uma vez confirmamos que eram promastigotas distintos.

Posteriormente, aprofundamos as análises morfológicas avaliando este isolado por microscopia eletrônica de transmissão e microscopia eletrônica de varredura de promastigotas de cultura. Analisamos também amastigotas de lesão induzida na orelha de camundongos BALB/c por microscopia eletrônica de transmissão. Identificamos estruturas características de tripanosomatídeos como mitocôndria única contendo DNA mitocondrial e bolso flagelar e alguns cortes transversais de flagelo permitiram identificação de axonema típico. Nas preparações de tecido, confirmou-se a infectividade do isolado em camundongos, pela detecção de amastigotas.

Verificamos a presença de uma estrutura arredondada em formato de "bainha" localizada na extremidade anterior em mais de $85 \%$ dos promastigotas. Quando não se observava essa estrutura atípica via-se promastigotas com flagelos curtos. Por microscopia eletrônica de varredura observamos a presença de sulcos ao redor do corpo do parasita e alguns apresentavam corpúsculos arredondados ou miceliformes na porção anterior e/ou aderidos ao corpo do parasita.

Os resultados até então obtidos nos levaram a avaliar se essa estrutura arredondada localizada na porção anterior apresentava antígenos presentes em flagelos de promastigotas convencionais. Para isso, avaliamos por imunofluorescência a marcação com anticorpos anti-tubulina que confirmou a ausência ou encurtamento drástico da estrutura flagelar. Outro anticorpo utilizado foi o monoclonal SST-3 que reconhece uma glicoproteína de superfície do flagelo de L. (V.) braziliensis (SILVEIRA et al., 2003). Neste caso, observamos marcação somente no flagelo da cepa referência de L. (V.) braziliensis MHOM/BR/1975/M2903 e no isolado EFSF/06/GO não foi detectada marcação na estrutura arredondada, mas sim no corpo celular do parasita. Acredita-se que esse isolado apresenta alguma deficiência na maquinaria responsável pela elongação do flagelo. 
Segundo Sacks e Kamhawi (2001), durante o processo de diferenciação dos promastigotas a adesão dos parasitas nas microvilosidades do intestino do vetor ocorre via flagelo. Visto que o isolado EFSF/06/GO não possui flagelo alongado, será interessante investigar como ocorre a diferenciação desse isolado no hospedeiro invertebrado. 


\section{Conclusões}




\section{Conclusões}

Dos 16 isolados obtidos, foi confirmada a identificação de 11 isolados como L. (V.) braziliensis, 3 como $L$. (L.) amazonensis e 2 desses isolados foram identificados como $L$. (L.) major-like que foram confirmados também por tipagem por anticorpos monoclonais.

O microteste de MTT modificado mostrou-se eficaz para avaliação da sensibilidade in vitro de promastigotas de Leishmania e macrófagos de medula como modelo de infecção por $L$. $(V$.) braziliensis. A atividade de tamoxifeno e anfotericina $B$ foi similar entre os isolados de Leishmania avaliados. Foi observada uma variação maior da atividade desses isolados na presença de Glucantime ${ }^{\circledR}$, sendo que os isolados de L. (V.) braziliensis apresentaram maior sensibilidade a essa droga. Não foi observada correlação da resposta clínica dos pacientes ao tratamento com a atividade in vitro.

O modelo de infecção por L. (V.) braziliensis na orelha pode ser usado para avaliação da eficácia de drogas antileishmania, mas deve ser considerada a progressão da infecção e a carga parasitária. Tamoxifeno reduziu a carga parasitária e tamanho da lesão de camundongos infectados com L. (V.) braziliensis.

Um isolado apresentou morfologia flagelar distinta daquela observada em promastigotas convencionais de Leishmania. 
Referências Bibliográficas 


\section{Referências bibliográficas ${ }^{*}$}

ABDO, M. G.; ELAMIN, W. M.; KHALIL, E. A.; MUKHTAR, M. M. Antimony-resistant Leishmania donovani in eastern Sudan: incidence and in vitro correlation. East. Mediterr. Health J., v. 9, n.4, p. 837-843, 2003.

ALLEN, S.; NEAL, R. A. The in vitro susceptibility of macrophages infected with amastigotes of Leishmania spp. to pentavalent antimonial drugs and other compounds with special relevance to cutaneous isolates. In: HART, D.T. Leishmaniasis. New York: Plenum Press, 1989. p. 711-720.

ALTAMIRANO-ENCISO, A. J.; MARZOCHI, M. C.; MOREIRA, J. S.; SCHUBACH, A. O.; MARZOCHI, K. B. Sobre a origem e dispersão das leishmanioses cutânea e mucosa com base em fontes históricas pré e pós-colombianas. Hist. Cienc. Saude Manguinhos, v. 10, n. 3, p. 852-882, 2003.

ALTAN, N.; CHEN, Y.; SCHINDLER, M.; SIMON, S. M. Tamoxifen inhibits acidification in cells independent of the estrogen receptor. Proc. Natl. Acad. Sci. U S A., v. 96, n. 8, p. 4432-4437, 1999.

ANDRADE, M. S.; BRITO, M. E. F.; DA SILVA, S. T.; LIMA, B. S.; ALMEIDA, E. L.; ALBUQUERQUE, E. L.; MARINHO JÚNIOR, J. F.; ISHIKAWA, E.; CUPOLILLO, E.; BRANDÃO-FILHO, S. P. Leishmaniose tegumentar americana causada por Leishmania (Viannia) braziliensis, em área de treinamento militar na Zona da Mata de Pernambuco. Rev. Soc. Bras. Med. Trop., v. 38, n. 3, p. 229-233, 2005.

AZEREDO-COUTINHO, R. B.; MENDONÇA, S. C.; CALLAHAN, H.; PORTAL, A. C.; MAX, G. Sensitivity of Leishmania braziliensis promastigotes to meglumine antimoniate (glucantime) is higher than that of other Leishmania species and correlates with response to therapy in American tegumentary leishmaniasis. J. Parasitol., v. 93, n. 3, p. 688-693, 2007.

BAGINSKI, M.; STERNAL, K.; CZUB, J.; BOROWSKI, E. Molecular modelling of membrane activity of amphotericin $B$, a polyene macrolide antifungal antibiotic. Acta Biochim. Pol., v. 52, n. 3, p. 655-658, 2005.

BARRAL, A.; PEDRAL-SAMPAIO, D.; GRIMALDI JUNIOR, G.; MOMEN, H.; MCMAHONPRATT, D.; RIBEIRO DE JESUS, A.; ALMEIDA, R.; BADARO, R.; BARRAL-NETTO, M.; CARVALHO, E. M. Leishmaniasis in Bahia, Brazil: evidence that Leishmania amazonensis produces a wide spectrum of clinical disease. Am. J. Trop. Med. Hyg., v. 44, n. 5, p. 536-546, 1991.

BEGGS, W. H. Drug protonation and $\mathrm{pH}$ in relation to the lethal action of tamoxifen on Candida albicans. J. Antimicrob. Chemother., v. 37, n. 4, p. 841-842, 1996.

\footnotetext{
* De acordo com:

ASSOCIAÇÃO BRASILEIRA DE NORMAS TÉCNICAS. NBR 6023: Informação e documentação: referências: elaboração. Rio de Janeiro, 2002.
} 
BERMAN, J. D.; BADARO, R.; THAKUR, C. P.; WASUNNA, K. M.; BEHBEHANI, K.; DAVIDSON, R.; KUZOE, F.; PANG, L.; WEERASURIYA, K.; BRYCESON, A. D. Efficacy and safety of liposomal amphotericin $B$ (AmBisome) for visceral leishmaniasis in endemic developing countries. Bull. World Health Organ., v. 76, n. 1, p. 25-32, 1998.

BERMÚDEZ, H.; ROJAS, E.; GARCIA, L.; DESJEUX, P.; DUJARDIN, J. C.; BOELAERT, M.; CHAPPUIS, F. Generic sodium stibogluconate is as safe and effective as branded meglumine antimoniate, for the treatment of tegumentary leishmaniasis in Isiboro Secure Park, Bolivia. Ann. Trop. Med. Parasitol., v. 100, n. 7, p. 591-600, 2006.

BERZUNZA-CRUZ, M.; BRICAIRE, G.; SALAIZA SUAZO, N.; PÉREZ-MONTFORT, R.; BECKER, I. PCR for identification of species causing American cutaneous leishmaniasis. Parasitol. Res., v. 104, n. 3, p. 691-699, 2009.

BHATTACHARYA, S. K.; SUR, D.; KARBWANG, J. Childhood visceral leishmaniasis. Indian. J. Med. Res., v. 123, n. 3, p. 353-356, 2006.

BLUM, J.; DESJEUX, P.; SCHWARTZ, E.; BECK, B.; HATZ, C. Treatment of cutaneous leishmaniasis among travelers. J. Antimicrob. Chemother., v. 53, n. 2, p. 158-166, 2004.

CARVALHO, M. de L.; DE ANDRADE, A. S.; FONTES, C. J.; HUEB, M.; DE OLIVEIRA SILVA, S.; MELO, M. N. Leishmania (Viannia) braziliensis is the prevalent species infecting patients with tegumentary leishmaniasis from Mato Grosso State, Brazil. Acta Trop., v. 98, n. 3, p. 277-285, 2006.

CASTILHO, T. M.; SHAW, J. J.; FLOETER-WINTER, L. M. New PCR assay using glucose-6-phosphate dehydrogenase for identification of Leishmania species. J. Clin. Microbiol., v. 41, n. 2, p. 540-546, 2003.

CHEN, Y.; SCHINDLER, M.; SIMON, S. M. A mechanism for tamoxifen-mediated inhibition of acidification. J. Biol. Chem., v. 274, n. 26, p. 18364-18373, 1999.

COHEN, S. N.; CHANG, A. C.; HSU, L. Nonchromosomal antibiotic resistance in bacteria: genetic transformation of Escherichia coli by R-factor DNA. Proc. Natl. Acad. Sci., v. 69, n. 8, p. 2110-2114, 1972.

COLAKOGLU, M.; FIDAN YAYLAL, G.; YALCIN COLAKOGLU, N.; YILMAZ, M.

Successful treatment of visceral leishmaniasis with fluconazole and allopurinol in a patient with renal failure. Scand. J. Infect. Dis., v. 38, n. 3, p. 208-210, 2006.

COSTA, C. H. Characterization and speculations on the urbanization of visceral leishmaniasis in Brazil. Cad. Saude Publica, v. 24, n. 12, p. 2959-2963, 2008.

COSTA, J. M. L. Epidemiologia das Leishmanioses no Brasil. Gazeta Médica da Bahia. v. 75, n. 1 , p. 3-17, 2005.

CROFT, S. L.; YARDLEY, V. Chemotherapy of Leishmaniasis. Curr. Pharm. Design, v. 8, n. 4, p. 319-342, 2002. 
CROFT, S. L.; COOMBS, G. H. Leishmaniasis - current chemotherapy and recent advances in the search for novel drugs. Trends Parasitol., v.19, n. 11, p. 502-508, 2003. Review.

CROFT, S. L.; SEIFERT, K.; YARDLEY, V. Current scenario of drug development for leishmaniasis. Indian J. Med. Res., v. 123, n. 3, p. 399-410, 2006.

CUPOLILLO, E.; GRIMALDI JÚNIOR, G.; MOMEN, H.; BEVERLEY, S. M. Intergenic region typing (IRT): a rapid molecular approach to the characterization and evolution of Leishmania. Mol. Biochem. Parasitol., v. 73, n. 1-2, p. 145-155, 1995.

DANTAS-TORRES, F.; BRANDAO-FILHO, S. P. Geographical expansion of visceral leishmaniasis in the State of Pernambuco. Rev. Soc. Bras. Med. Trop., v. 39, n. 4, p. 352-356, 2006.

de MOURA, T. R.; NOVAIS, F. O.; OLIVEIRA, F.; CLARÊNCIO, J.; NORONHA, A.; BARRAL, A.; BRODSKYN, C.; DE OLIVEIRA, C. I. Toward a novel experimental model of infection to study American cutaneous leishmaniasis caused by Leishmania braziliensis.

Infect. Immun., v. 73, n. 9, p. 5827-5834, 2005.

de OLIVEIRA-SILVA, F.; de MORAIS-TEIXEIRA, E.; RABELLO, A. Antileishmanial activity of azithromycin against Leishmania (Leishmania) amazonensis, Leishmania (Viannia) braziliensis, and Leishmania (Leishmania) chagasi. Am. J. Trop. Med. Hyg., v. 78, n. 5, p. 745-749, 2008.

DESJEUX, P. Leishmaniasis: current situation and new perspectives. Comp. Imunol. Microbiol. Infect Dis., v. 27, n. 5, p. 305-318, 2004.

DISCH, J.; PEDRAS, M. J.; ORSINI, M.; PIRMEZ, C.; DE OLIVEIRA, M. C.; CASTRO, M.; RABELLO, A. Leishmania (Viannia) subgenus kDNA amplification for the diagnosis of mucosal leishmaniasis. Diagn. Microbiol. Infect. Dis., v. 51, n. 3, p. 185-190, 2005.

DRUTZ, D. J.; HUPPERT, M.; SUN, S. H.; MCGUIRE, W. L. Human sex hormones stimulate the growth and maturation of Coccidioides immitis. Infect Immun., v. 32, n. 2, p. 897-907, 1981.

FOLLADOR, I.; ARAUJO, C.; CARDOSO, M. A.; TAVARES-NETO, J.; BARRAL, A.; MIRANDA, J. C.; BITTENCOURT, A.; CARVALHO, E. M. Surto de leishmaniose tegumentar americana em Canoa, Santo Amaro, Bahia, Brasil. Rev. Soc. Bras. Med. Trop., v. 32, n. 5, p. 497-503, 1999.

GOMES, C. M. C.; SILVEIRA, F. T.; LAURENTI, M. D.; COSTA, J. M. L.; TOMOKANE, T. Y.; SOUZA, M. G. T.; CORBETT, C. E. P. Biological behavior of Leishmania (Leishmania) amazonensis isolated from different clinical forms of American tegumentar leishmaniasis in Balb/c mice. Rev. Inst. Méd. Trop. São Paulo, v. 45 n. 13, p. 65, 2003.

GONTIJO, C. M. F.; MELO, M. N. Leishmaniose Visceral no Brasil: quadro atual, desafios e perspectivas. Rev. Bras. Epidemiol., v. 7, n. 3, p. 338-349, 2004.

GONZÁLEZ, U.; PINART, M.; REVEIZ, L.; ALVAR, J. Interventions for Old World cutaneous leishmaniasis. Cochrane Database Syst Rev., v. 8, n. 4, CD005067, 2008. 
GRILLI, S. Tamoxifen (TAM): the dispute goes on. Ann. Ist. Super. Sanita, v. 42, n. 2, p. 170-173, 2006.

GROGL, M.; THOMASON, T. N.; FRANKE, E. D. Drug resistance in leishmaniasis: its implication in systemic chemotherapy of cutaneous and mucocutaneous disease. Am. J. Trop. Med. Hyg., v. 47, n. 1, p. 117-126, 1992.

HANHAM, C. A.; SHAW, J. J.; LAINSON, R. Monoclonal antibodies that react with Leishmania (Viannia) naiffi. J. Parasitol., v. 77, n. 5, p. 680-687,1991.

HADIGHI, R.; MOHEBALI, M.; BOUCHER, P.; HAJJARAN, H.; KHAMESIPOUR, A.; OUELLETTE, M. Unresponsiveness to Glucantime treatment in Iranian cutaneous leishmaniasis due to drug-resistant Leishmania tropica parasites. PLoS Med., v. 3, n. 5, p. 162. Epub 2006.

HOWARD, M. K.; PHAROAH, M. M.; ASHALL, F.; MILES, M. A. Human urine stimulates growth of Leishmania in vitro. Trans. R. Soc. Trop. Med. Hyg., v. 85, n. 4, p. 477-479, 1991.

INADA, E. T.; WATANABE, K. P.; TANAKA, S. G.; SAKAKISBARA, L. A. Ocular toxicity caused by tamoxifen: case report. Arq. Bras. Oftalmol., v. 68, n. 4, p. 554-556, 2005.

JERONIMO, S. M.; DUGGAL, P.; BRAZ, R. F.; CHENG, C.; MONTEIRO, G. R.; NASCIMENTO, E. T.; MARTINS, D. R.; KARPLUS, T. M.; XIMENES, M. F.; OLIVEIRA, C. C.; PINHEIRO, V. G.; PEREIRA, W.; PERALTA, J. M.; SOUSA, J.; MEDEIROS, I. M.; PEARSONI, R. D.; BURNS, T. L.; PUGH, E. W.; WILSON, M. E. An emerging peri-urban pattern of infection with Leishmania chagasi, the protozoan causing visceral leishmaniasis in northeast Brazil. Scand. J. Infect Dis., v. 36, n. 6-7, p. 443-449, 2004.

JHA, T. K. Drug unresponsiveness \& combination therapy for kala-azar. Indian J. Med. Res., v. 123, n. 3, p. 389-398, 2006.

JONAT, W.; GNANT, M.; BOCCARDO, F.; KAUFMANN, M.; RUBAGOTTI, A.; ZUNA, I.; GREENWOOD, M.; JAKESZ, R. Effectiveness of switching from adjuvant tamoxifen to anastrozole in postmenopausal women with hormone-sensitive early-stage breast cancer: a meta-analysis. Lancet Oncol., v. 7, n. 12, p. 991-996, 2006.

JORDAN, V. C. Tamoxifen: a most unlikely pioneering medicine. Nat. Rev. Drug. Discov., v. 2, n. 3, p. 205-213, 2003.

KAMAU, S. W.; HURTADO, M.; MULLER-DOBLIES, U. U.; GRIMM, F.; NUNEZ, R. Flow cytometric assessment of allopurinol susceptibility in Leishmania infantum promastigote. Cytometry, v. 40, n. 4, p. 353-360, 2000.

KISHORE, K.; KUMAR, V.; KESARI, S.; DINESH, D. S.; KUMAR, A. J.; DAS, P.; BHATTACHARYA, S. K. Vector control in leishmaniasis. Indian J. Med. Res., v. 123, n. 3, p. 467-472, 2006.

KUMAR, D.; KULSHRESTHA, A.; SINGH, R.; SALOTRA, P. In vitro susceptibility of field isolates of Leishmania donovani to Miltefosine and amphotericin B: correlation with 
sodium antimony gluconate susceptibility and implications for treatment in areas of endemicity. Antimicrob. Agents Chemother., v. 53, n. 2, p. 835-838, 2009.

LAINSON, R.; RANGEL, E. F. Lutzomyia longipalpis and the eco-epidemiology of American visceral leishmaniasis, with particular reference to Brazil - A Review. Mem. Inst. Oswaldo Cruz, v. 100, n. 8, p. 811-827, 2005.

LIMA, H. C.; BLEYENBERG, J. A.; TITUS, R. G. A simple method for quantifying Leishmania in tissues of infected animals. Parasitol.Today, v. 13, n. 2, p. 80-82, 1997.

LIRA, R.; SUNDAR, S.; MAKHARIA, A.; KENNEY, R.; GAM, A.; SARAIVA, E.; SACKS, D. Evidence that the high incidence of treatment failures in Indian kala-azar is due to the emergence of antimony-resistant strains of Leishmania donovani. J. Infect Dis., v. 180, n. 2, p. 564-567, 1999.

MAIA, C.; ROLÃO, N.; NUNES, M.; GONÇALVES, L.; CAMPINO, L. Infectivity of five different types of macrophages by Leishmania infantum. Acta Trop., v. 103, n. 2, p. 150$155,2007$.

MANANDHAR, K. D.; YADAV, T. P.; PRAJAPATI, V. K.; KUMAR, S.; RAI, M.; DUBE, A.; SRIVASTAVA, O. N.; SUNDAR, S. Antileishmanial activity of nano-amphotericin B deoxycholate. J. Antimicrob. Chemother., v. 62, n. 2. p. 376-380, 2008.

MCMAHON-PRATT, D.; BENNETT, E.; DAVID, J. R. Monoclonal antibodies that distinguish subspecies of Leishmania braziliensis. J. Immunol., v.129, n. 3, p. 926-927, 1982.

MEDINA-ACOSTA, E.; CROSS, G. A. M. Rapid isolation of DNA from trypanosomatid protozoa using a simple "mini-prep" procedure. Mol. Biochem. Parasitol., v. 59, n. 2, p. 327-329, 1993.

MIGUEL, D. C.; YOKOYAMA-YASUNAKA, J. K.; ANDREOLI, W. K.; MORTARA, R. A.; ULIANA, S. R. Tamoxifen is effective against Leishmania and induces a rapid alkalinization of parasitophorous vacuoles harbouring Leishmania (Leishmania) amazonensis amastigotes. J. Antimicrob. Chemother., v. 60, n. 3, p. 526-534, 2007.

MIGUEL, D. C.; YOKOYAMA-YASUNAKA, J. K.; ULIANA, S. R. Tamoxifen Is Effective in the Treatment of Leishmania amazonensis Infections in Mice. PLoS Negl. Trop. Dis., $v$. 11 , n. 2, p. 246-249, 2008

MIGUEL, D. C.; ZAULI-NASCIMENTO, R.C.; YOKOYAMA-YASUNAKA, J. K.; KATZ, S.; BARBIÉRI, C. L.; ULIANA, S. R. Tamoxifen as a potential antileishmanial agent: efficacy in the treatment of Leishmania braziliensis and Leishmania chagasi infections. J.

Antimicrob. Chemother., v. 63, n. 2, p. 365-368, 2009.

MINISTÉRIO DA SAÚDE. Disponível em:

http://portal.saude.gov.br/portal/arquivos/pdf/casos_conf_lta.pdf. Acesso em: 12 fev. 2009. 
MINISTÉRIO DA SAÚDE. Sistema Nacional de Vigilância em Saúde: relatório de situação: Goiás, 2005. Disponível em: http://portal.saude.gov.br/portal/arquivos/pdf. Acesso em: 14 dez. 2007.

MINISTÉRIO DA SAÚDE - Brasil. Atlas de leishmaniose tegumentar americana: diagnósticos clínico e diferencial, 2006. Disponível em: http://www.saude.gov.br/bvs. Acesso em: 12 jan. 2009.

MINISTÉRIO DA SAÚDE. Manual de Vigilância da Leishmaniose Tegumentar Americana, 2007. Disponível em:

http://www.portal.saude.gov.br/portal/arquivos/pdf/manual_Ita_2ed.pdf. Acesso em: 13 mar. 2008.

MOLYNEUX, D. H.; KILLICK-KENDRICK, R. Morphology, ultrastructure and life cycles. In: PETERS, W; KILLICK-KENDRICK, R. (Ed.). The Leishmaniases in Biology and Medicine. London: Academic Press, 1987. p. 1-119.

MOMEN, H.; PACHECO, R. S.; CUPOLILLO, E.; GRIMALDI JÚNIOR, G. Molecular evidence for the importation of Old World Leishmania into the Americas. Biol. Res., v. 26, n. $1-2$, p. 249-255, 1993.

MOREIRA, M. E.; DEL PORTILLO, H. A.; MILDER, R. V.; BALANCO, J. M.; BARCINSKI, M. A. Heat shock induction of apoptosis in promastigotes of the unicellular organism Leishmania (Leishmania) amazonensis. J. Cell. Physiol., v. 16, n. 7(2), p. 305-313, 1996.

MOSMANN, T. Rapid colorimetric assay for cellular growth and survival: application to proliferation and cytotoxicity assays. J. Immunol. Methods, v. 65, n. 1-2, p. 55-63, 1983.

MULLIS, K. B.; FALOONA, F.; SCHARF, S.; SAIKI, R.K.; HORN, G. T.; ERLICH, H. A. Specific enzymatic amplification of DNA in vitro: the polymerase chain reaction. Cold. Spring Harb. Symp. Quant. Biol., v. 51, n. 1, p. 263-273, 1986.

MURRAY, H. W.; BERMAN, J. D.; DAVIES, C. R.; SARAVIA, N. G. Advances in Leishmaniasis. Lancet, v. 366, n. 9496, p. 1561-1577, 2005.

MUSA, A. M.; KHALIL, E. A.; MAHGOUB, F. A.; HAMAD, S.; ELKADARU, A. M.; EL HASSAN, A. M. Efficacy of liposomal amphotericin B (AmBisome) in the treatment of persistent post-kala-azar dermal leishmaniasis (PKDL). Ann. Trop. Med. Parasitol., v. 99, n. 6, p. 563-569, 2005.

NEAL, R. A.; CROFT, S. L. An in vitro system for determining the activity of compounds against the intracellular amastigote form of Leishmania donovani. J. Antimicrob.

Chemother., v. 14, n. 5, p. 463-475, 1984.

OLIVEIRA-NETO, M. P.; SCHUBACH, A.; MATTOS, M.; GONCALVES-COSTA, S. C.; PIRMEZ, C. A low-dose antimony treatment in 159 patients with American cutaneous leishmaniasis: extensive follow-up studies (up to 10 years). Am. J. Trop. Méd. Hyg., v. 57, n. 6, p. 651-655, 1997. 
ORGANIZAÇÃO MUNDIAL DA SAÚDE. Disponível em:

http://www.who.int/leishmaniasis/disease_epidemiology/en/index.html. Acesso em: 13 mar. 2009.

OUELLETTE, M.; DRUMMELSMITH, J.; PAPADOPOULOU, B. Leishmaniasis: drugs in the clinic, resistance and new developments. Drug Resist. Updat., v. 7, n. 4-5, p. 257266, 2004. Review.

PALACIOS, R.; OSORIO, L. E.; GRAJALEW, L. F.; OCHOA, M. T. Treatment failure in children in a randomized clinical trial with 10 and 20 days of meglumine antimonate for cutaneous leishmaniasis due to Leishmania viannia species. Am. J. Trop. Med. Hyg., v. 64, n. 3-4, p. 187-193, 2001.

PETER, W. The treatment of kala-azar: new approach to an old problem. Ind. J. Med. Res., v. 73, p. 1-18, 1981. Suppl.

PINTADO, V.; LÓPEZ-VÉLEZ, R. HIV-associated visceral leishmaniasis. Clin. Microbiol. Infect, v. 7, n. 6, p. 291-300, 2001.

PONTIGGIA, O.; RODRIGUEZ, V.; FABRIS, V.; RAFFO, D.; BUMASCHN, Y. V.; FISZMAN, G.; DE KIER JOFFÉ, E. B.; SIMIAN, M. Establishment of an in vitro estrogendependent mouse mammary tumor model: a new tool to understand estrogen responsiveness and development of tamoxifen resistance in the context of stromalepithelial interactions. Breast Cancer Res. Treat. Epub ahead of print, 2008.

PRATA, A.; SILVA-VERGARA, M. L.; COSTA, L.; ROCHA, A.; KROLEWIECKI, A.; SILVA, J. C.; de PAULA, E. V.; PIMENTA JUNIOR, F. G.; GIRALDO, L. E. Efficacy of azithromycin in the treatment of cutaneous leishmaniasis. Rev. Soc. Bras. Med. Trop., v. 36, n. 1, p. 65-69, 2003.

RAMOS, C. S.; FRANCO, F. A.; SMITH, D. F.; ULIANA, S. R. Characterisation of a new Leishmania META gene and genomic analysis of the META cluster. FEMS Microbiol. Lett., v. 238, n. 1, p. 213-219, 2004.

RATH, S.; TRIVELIN, L. A.; IMBRUNITO, T. R.; TOMAZELA, D. M.; JESÚS, M. N. de; MARZAL, P. C.; ANDRADE JUNIOR, H. F. de; TEMPONE, A. G. Antimoniais empregados no tratamento da leishmaniose: estado da arte. Quím. Nova, v. 26, n. 4, p. 550-555, 2003.

REY, L. Bases da Parasitologia Médica. $2^{\underline{a}}$ ed. Rio de Janeiro: Guanabara Koogan, 2002.

ROJAS, R.; VALDERRAMA, L.; VALDERRAMA, M.; VARONA, M. X.; OUELLETTE, M.; SARAVIA, N. G. Resistance to antimony and treatment failure in human Leishmania (Viannia) infection. J. Infect Dis., v. 193, n. 10, p. 1375-1383, 2006.

ROMERO, G. A. S.; GUERRA, M. V. de F.; PAES, M. G.; MACEDO, V. de O. Comparison of cutaneous leishmaniasis due to Leishmania (Viannia) braziliensis and $L$. (V.) guyanensis in Brazil: clinical findings and diagnostic approach. Clin. Infect Dis., v. 32, n. 9, p. 1304-1312, 2001. 
SACKS, D.; KAMHAWI, S. Molecular aspects of parasite-vector and vector-host interactions in leishmaniasis. Annu. Rev. Microbiol., v. 55, p. 453-483, 2001. Review.

SAMPAIO, R. N. R.; ANDRADE, G. B.; PEREIRA, A. C.; SILVA, E. A.; CUBA, C. A. C. Estudo comparativo de técnicas de demonstração de amastigotas e isolamento de promastigotas no diagnóstico da leishmaniose tegumentar americana. An. Bras. Dermatol., v. 77, n. 5, p. 557-561, 2002.

SANGER, F.; COULSON, A. R. A rapid method for determining sequences in DNA by primed synthesis with DNA polymerase. J. Mol. Biol., v. 94, n. 3, p. 441-448, 1975.

SANTOS, M. A.; MARQUES, R. C.; FARIAS, C. A.; VASCONCELOS, D. M.; STEWART, J. M.; COSTA, D. L.; COSTA, C. H. Predictors of an unsatisfactory response to pentavalent antimony in the treatment of American visceral leishmaniasis. Rev. Soc.

Bras. Med. Trop., v. 35, n. 6, p. 629-633, 2002.

SHARIEF, A. H.; GASIM KHALIL, E. A.; THEANDER, T. G.; KHARAZMI, A.; OMER, S. A.; IBRAHIM, M. E. Leishmania donovani: an in vitro study of antimony-resistant amphotericin B-sensitive isolates. Exp. Parasitol., v. 114, n. 4, p. 247-252, 2006.

SHAW, J. J.; DE FARIA, D. L.; BASANO, S. A.; CORBETT, C. E.; RODRIGUES, C. J.; ISHIKAWA, E. A.; CAMARGO, L. M. The aetiological agents of American cutaneous leishmaniasis in the municipality of Monte Negro, Rondônia state, western Amazonia, Brazil. Ann. Trop. Med. Parasitol., v. 101, n. 8, p. 681-688, 2007.

SILVA, E. S.; GONTIJO, C. M. F.; PACHECO, R. S.; FIUZA, V. O.; BRAZIL, R. P. Visceral leishmaniasis in the Metropolitan Region of Belo Horizonte, State of Minas Gerais, Brazil. Mem. Inst. Oswaldo Cruz, v. 96, n. 3, p. 285-291, 2001.

SILVA-VERGARA, M. L.; SILVA, L. de A.; MANEIRA, F. R.; da SILVA, A. G.; PRATA, A. Azithromycin in the treatment of mucosal leishmaniasis. Rev. Inst. Med. Trop. São Paulo, v. 46, n. 3, p. 175-177, 2004.

SILVEIRA, T. G.; TAKAHASHI, H. K.; STRAUS, A. H. Immunolocalization of Leishmania (Viannia) braziliensis membrane antigens recognized by mAbs SST-2, SST-3, and SST-4. Parasitology, v. 127, n. 5, p. 449-456, 2003.

SINAGRA, A.; LUNA, C.; ABRAHAM, D.; IANNELLA, M.del. C.; RIARTE, A.; KROLEWIECKI, A. J. The activity of azithromycin against Leishmania (Viannia) braziliensis and Leishmania (Leishmania) amazonensis in the golden hamster model.

Rev. Soc. Bras. Med. Trop., v. 40, n. 6, p. 627-630, 2007.

SINGH, S.; SIVAKUMAR, R. Challenges and new discoveries in the treatment of leishmaniasis. J. Infect Chemother., v. 10, n. 6, p. 307-315, 2004.

SINGH, R.; KUMAR, D.; RAMESH, V.; NEGI, N.S.; SINGH, S.; SALOTRA, P. Visceral leishmaniasis, or kala azar (KA): high incidence of refractoriness to antimony is 
contributed by anthroponotic transmission via post-KA dermal leishmaniasis. J. Infect Dis., v. 194, n. 3, p. 302-306, 2006.

SOLOMON, M.; BAUM, S.; BARZILAI, A.; SCOPE, A.; TRAU, H.; SCHWARTZ, E. Liposomal amphotericin $B$ in comparison to sodium stibogluconate for cutaneous infection due to Leishmania braziliensis. J. Am. Acad. Dermatol., v. 56, n. 4, p. 612-616, 2007.

SOTO, J.; ARANA, B. A.; TOLEDO, J.; RIZZO, N.; VEGA, J. C.; DIAZ, A.; LUZ, M.; GUTIERREZ, P.; ARBOLEDA, M.; BERMAN, J. D.; JUNGE, K.; ENGEL, J.; SINDERMANN, H. Miltefosine for New World cutaneous leishmaniasis. Clin. Infect Dis. v. 38, n. 9, p. 1266-1272, 2004.

SOTO, J.; REA, J.; BALDERRAMA, M.; TOLEDO, J.; SOTO, P.; VALDA, L.; BERMAN, J.D. Efficacy of miltefosine for Bolivian cutaneous leishmaniasis. Am. J. Trop. Med. Hyg., v. 78, n. 2, p. 210-211, 2008.

SOTO-MANCIPE, J.; GROGL, M.; BERMAN, J. Evaluation of pentamidine for the treatment of cutaneous leishmaniasis in Colombia. Clin. Infect. Dis., v. 16, n. 3, p. 417425, 1993.

SUNDAR, S.; GUPTA, L. B.; RASTOGI, V.; AGRAWAL, G.; MURRAY, H. W. Shortcourse, cost-effective treatment with amphotericin B-fat emulsion cures visceral leishmaniasis. Trans. R. Soc. Trop. Med. Hyg., v. 94, n. 2, p. 200-204, 2000.

SUNDAR, S.; PAI, K.; KUMAR, R.; PATHAK-TRIPATHI, K.; GAM, A. A.; RAY, M.; KENNEY, R. T. Resistance to treatment in kala-azar: speciation of isolates from northeast India. Am. J. Trop. Med. Hyg., v. 65, n. 3, p. 193-196, 2001.

SUNDAR, S.; CHATTERJEE, M. Visceral leishmaniasis - current therapeutic modalities. Indian J. Med. Res., v. 123, n. 3, p. 345-352, 2006.

SWOFFORD, D. L. PAUP*. Phylogenetic Analysis Using Parsimony (*and Other Methods). Version 4. Sunderland, Massachusetts: Sinauer Associates, 1998.

THAKUR, C. P.; NARAYAN, S.; RANJAN, A. Epidemiological, clinical \& pharmacological study of antimony-resistant visceral leishmaniasis in Bihar, India. Indian J. Med. Res., v. 120, n. 3, p. 166-172, 2004.

TOJAL DA SILVA, A. C.; CUPOLILLO, E.; VOLPINI, A. C.; ALMEIDA, R.; SIERRA ROMERO, G. A. Species diversity causing human cutaneous leishmaniasis in Rio Branco, state of Acre, Brazil. Trop. Méd. Int. Health, v. 11, n. 9, p. 1388-1398, 2006.

ULIANA, S. R.; NELSON, K.; BEVERLEY, S. M.; CAMARGO, E. P.; FLOETER-WINTER, L. M. Discrimination amongst Leishmania by polymerase chain reaction and hybridization with small subunit ribosomal DNA derived oligonucleotides. J. Eukaryot. Microbiol., v. 41, n. 4, p. 324-330, 1994.

VERGEL, C.; PALACIOS, R.; CADENA, H.; POSSO, C. J.; VALDERRAMA, L.; PEREZ, M.; WALKER, J.; TRAVI, B. L.; SARAVIA, N. G. Evidence for Leishmania (Viannia) 
parasites in the skin and blood of patients before and after treatment. J. Infect Dis., v. 194 , n. 4, p. 503-511, 2006.

VOGEL, V. G.; COSTANTINO, J. P.; WICKERHAM, D. L.; CRONIN, W. M.; CECCHINI, R. S.; ATKINS, J. N.; BEVERS, T. B.; FEHRENBACHER, L.; PAJON JR, E.R.; WADE, J. L.; ROBIDOUX, A.; MARGOLESE, R. G.; JAMES, J.; LIPPMAN, S. M.; RUNOWICZ, C. D.; GANZ, P. A.; REIS, S. E.; MCCASKILL-STEVENS, W.; FORD, L. G.; JORDAN, V. C.;

WOLMARK, N. Effects of tamoxifen vs raloxifene on the risk of developing invasive breast cancer and other disease outcomes: the NSABP Study of Tamoxifen and Raloxifene (STAR) P-2 trial. JAMA, v. 295, n. 23, p. 2727-2741, 2006.

WERNECK, G. L.; BATISTA, M. S.; GOMES, J. R.; COSTA, D. L.; COSTA, C. H. Prognostic factors for death from visceral leishmaniasis in Teresina, Brazil. Infection, $v$. 31, n. 3, p. 174-177, 2003.

WILLIAMS, J. P.; MCDONALD, J. M.; MCKENNA, M. A.; JORDAN, S. E.; RADDING, W.; BLAIR, H. C. Differential effects of tamoxifen-like compounds on osteoclastic bone degradation, $\mathrm{H}(+)$-ATPase activity, calmodulin-dependent cyclic nucleotide phosphodiesterase activity, and calmodulin binding. J. Cell. Biochem., v. 66, n. 3, p. 358369, 1997.

WISEMAN, H.; LAUGHTON, M. J.; ARNSTEIN, H. R.; CANNON, M.; HALLIWELL, B. The antioxidant action of tamoxifen and its metabolites. Inhibition of lipid peroxidation. FEBS Lett. v, 263, n. 2, p. 192-194, 1990.

YARDLEY, V.; CROFT, S. L. Activity of liposomal amphotericin B against experimental cutaneous leishmaniasis. Antimicrob. Agents Chemother., v. 41, n. 4, p. 752-756, 1997.

YARDLEY, V.; ORTUNO, N.; LLANOS-CUENTAS, A.; CHAPPUIS, F.; DONCKER, S. D.; RAMIREZ, L.; CROFT, S.; AREVALO, J.; ADAUI, V.; BERMUDEZ, H.; DECUYPERE, S.; DUJARDIN, J. C. American tegumentary leishmaniasis: Is antimonial treatment outcome related to parasite drug susceptibility?J. Infect Dis., v. 194, n. 8, p. 1168-1175, 2006.

ZAKAI, H. A.; CHANCE, M. L.; BATES, P. A. In vitro stimulation of metacyclogenesis in Leishmania (Viannia) braziliensis, L. (Leishmania) donovani, L. (L.) major and L. (L.) mexicana. Parasitology, v. 116, n. 4, p. 305-309, 1998.

ZAMBONI, D. S.; RABINOVITCH, M. Nitric oxide partially controls Coxiella burnetii phase II infection in mouse primary macrophages. Infect. Immun., v. 71, n. 3, p. 1225-1233, 2003.

ZARATE, C. A. JR.; SINGH, J. B.; CARLSON, P. J.; QUIROZ, J.; JOLKOVSKY, L.; LUCKENBAUGH, D. A.; MANJI, H. K. Efficacy of a protein kinase $\mathrm{C}$ inhibitor (tamoxifen) in the treatment of acute mania: a pilot study. Bipolar Disord., v. 9, n. 6, p. 561-570, 2007.

ZITO, R. Problems in breast cancer prevention and therapy by tamoxifen. J. Exp. Clin. Cancer Res., n. 13, p. 99-101, 1994. 
Anexo A 

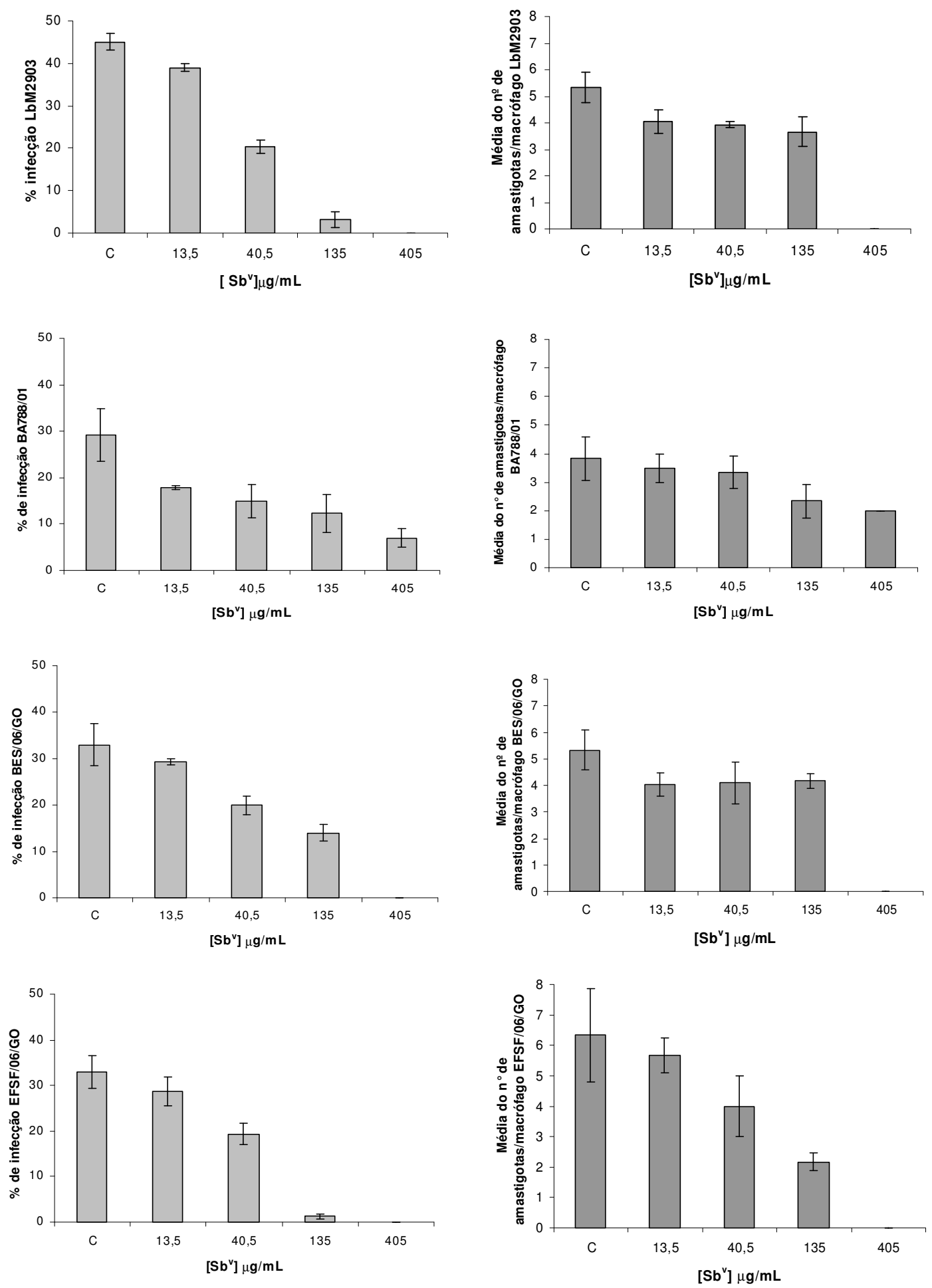

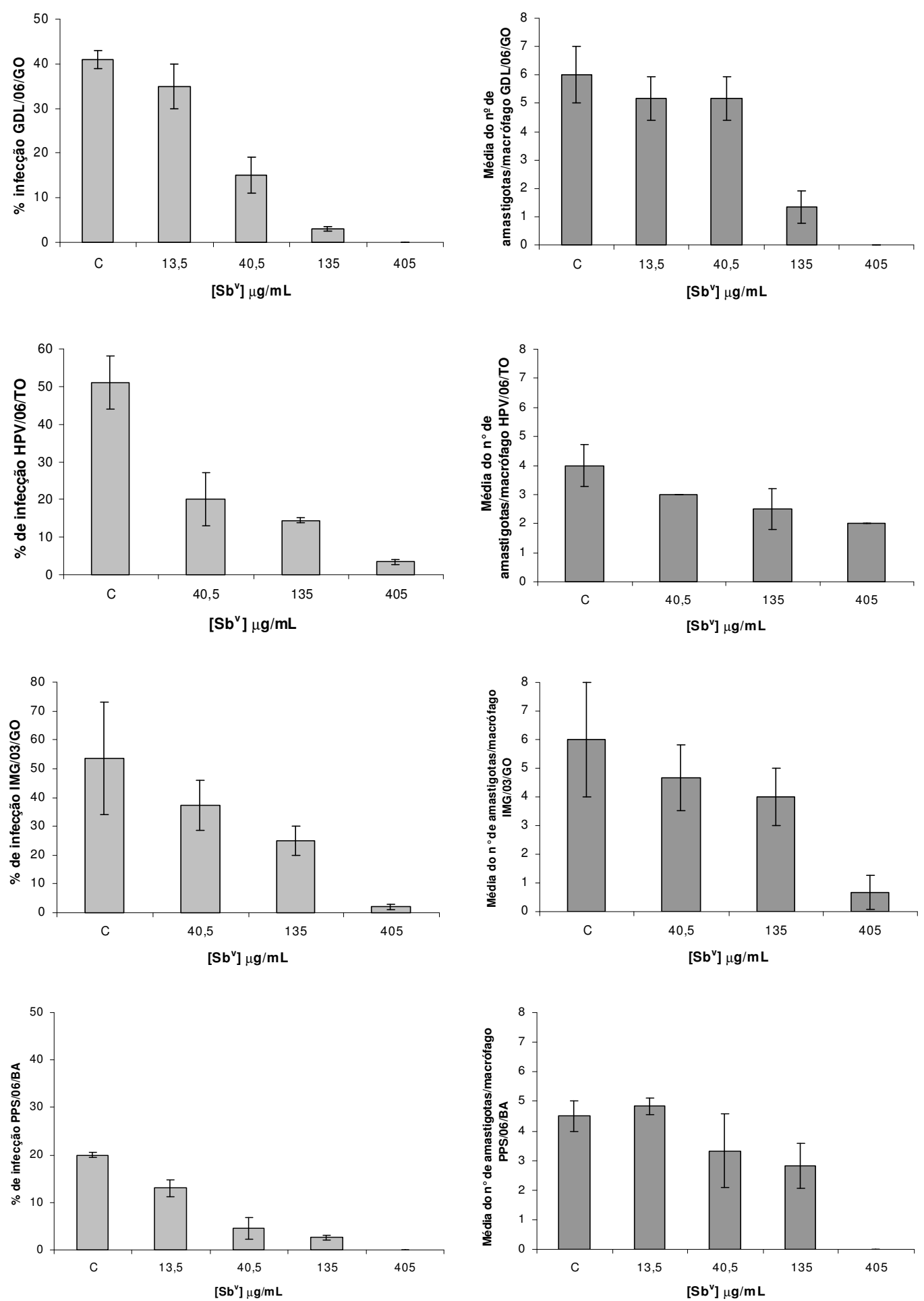

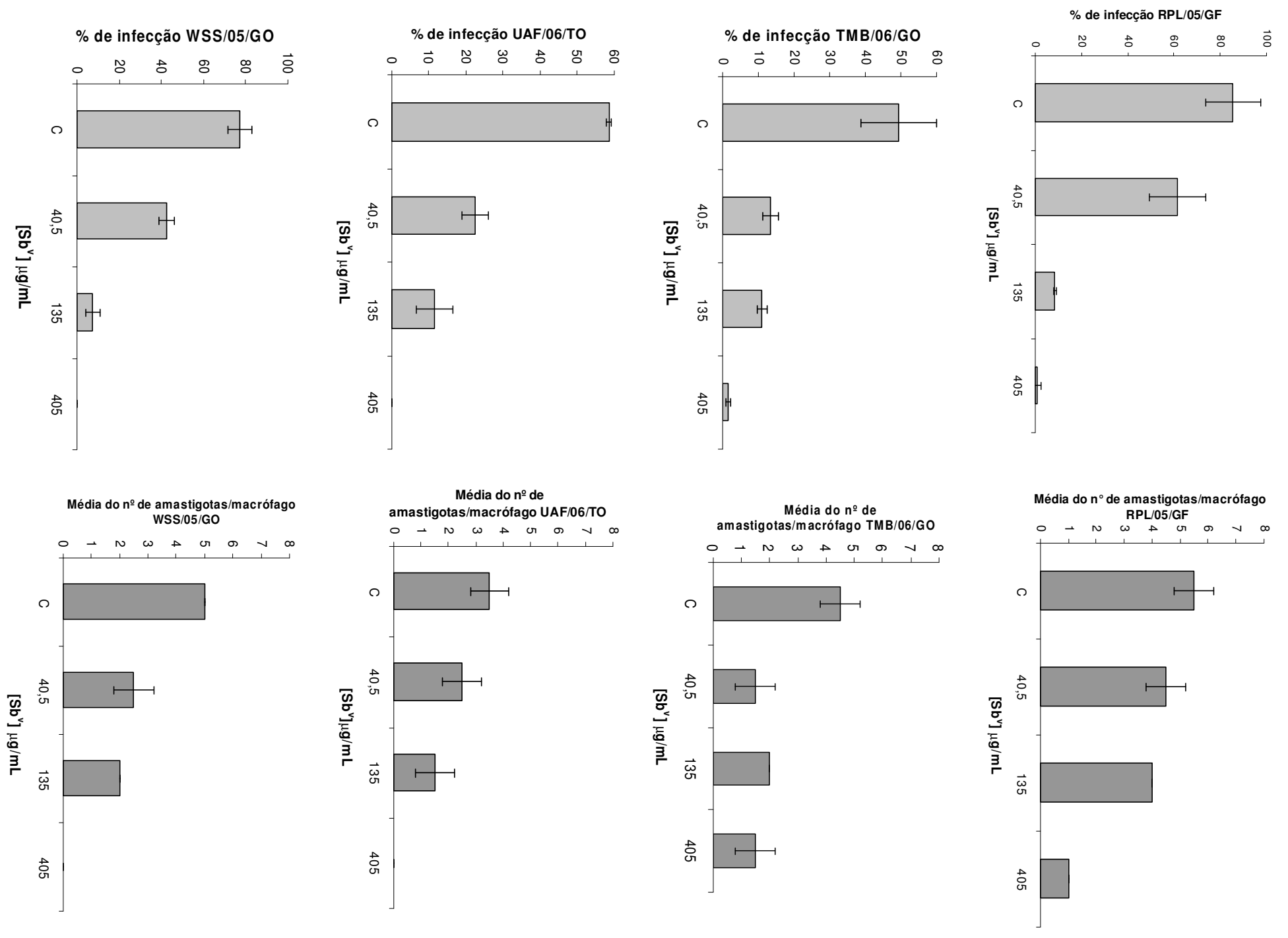

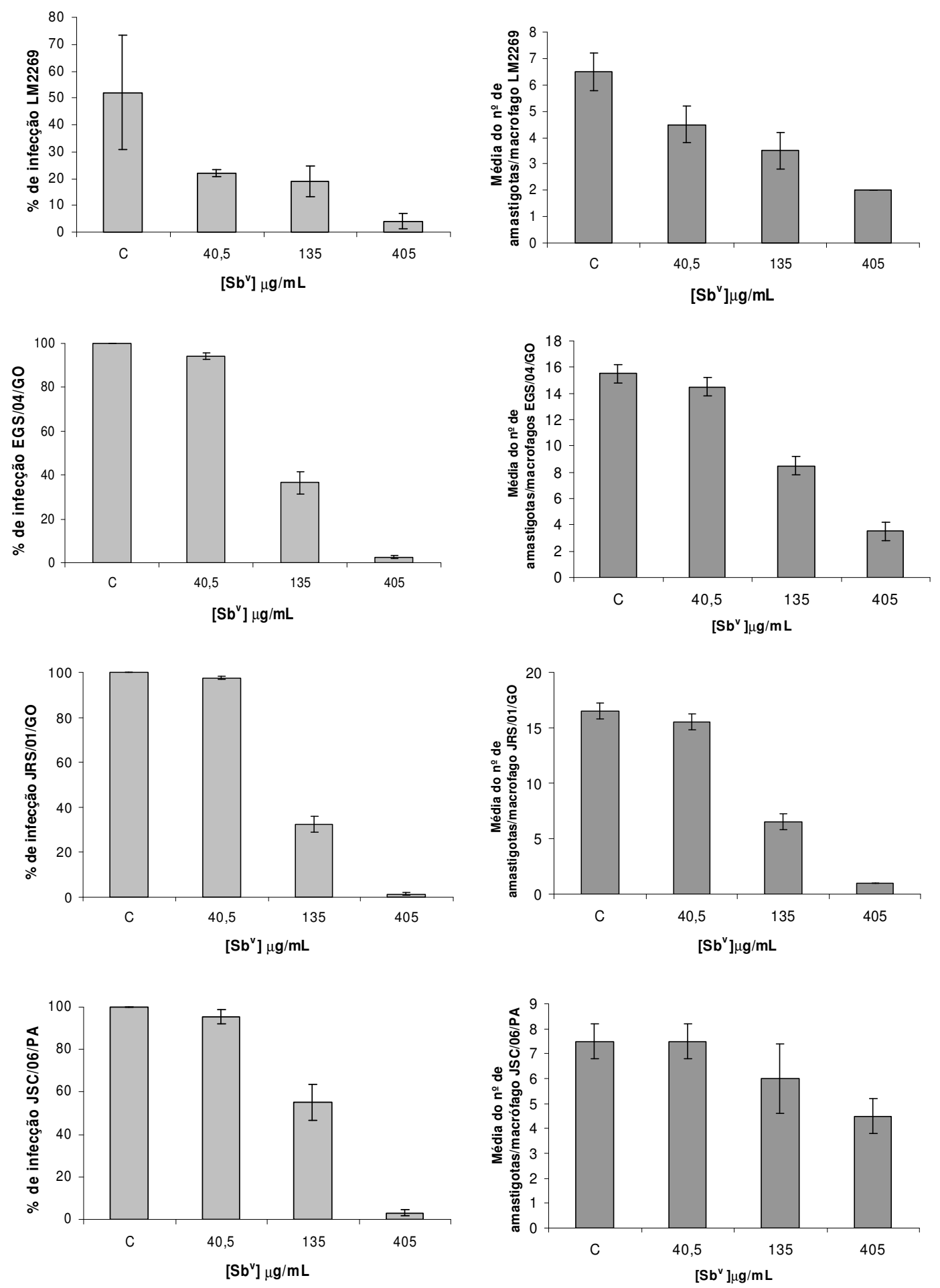

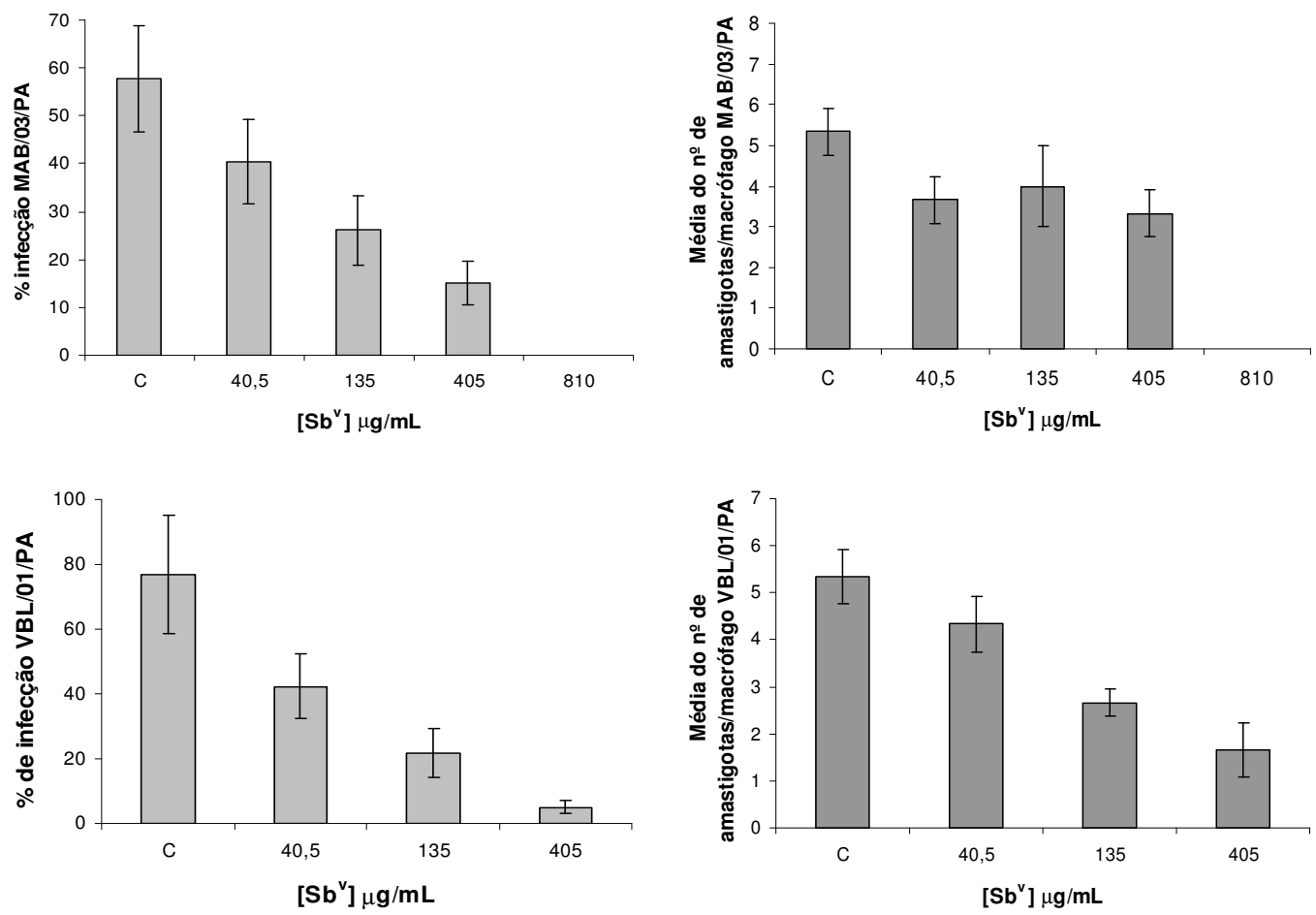

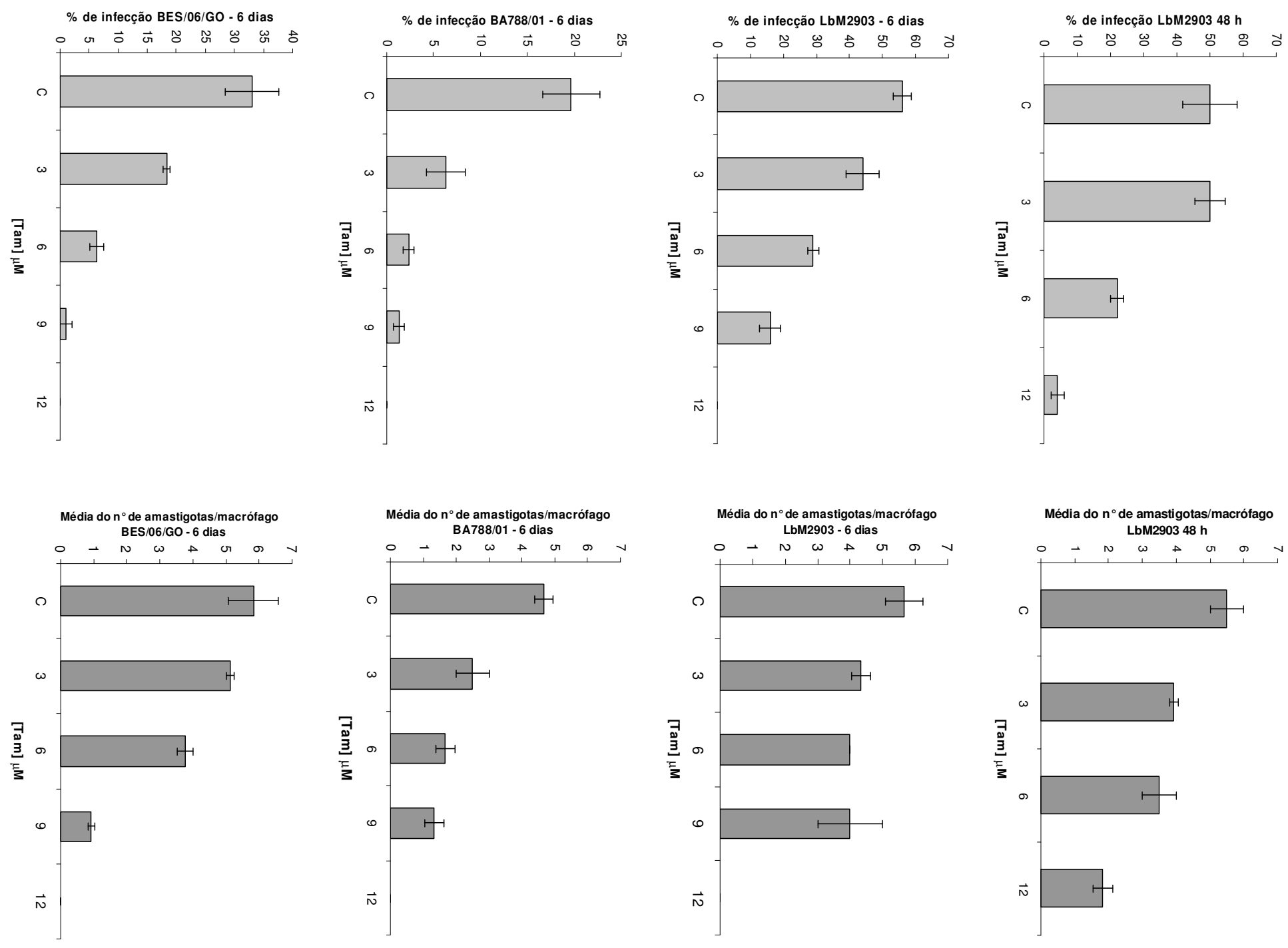
3.19 Avaliação da atividade de drogas contra amastigotas intracelulares

3.19.1 Macrófagos de peritônio e J774 A.1 42

3.19.2 Macrófagos THP-1 42

$\begin{array}{ll}\text { 3.19.3 Macrófagos de medula } & 43\end{array}$

3.19.4 Ensaios de citotoxicidade $\quad 43$

3.20 Camundongos BALB/C $\quad 44$

3.21 Infecção de camundongos BALB/c com isolados de L. (V.) braziliensis 44

3.22 Tratamento de camundongos BALB/c infectados com

L. (V.) braziliensis 44

3.23 Quantificação de parasitas por diluição limitante 45

3.24 Exame histopatológico 45

3.25 Avaliação macroscópica $\quad 45$

3.26 Microscopia eletrônica de transmissão 45

3.27 Microscopia eletrônica de varredura 46

3.28 Imunofluorescência 46

$\begin{array}{lr}3.29 & \text { Estatística }\end{array}$

4 Resultados $\quad 48$

$\begin{array}{ll}\text { 4.1 Condições de cultivo dos isolados } & 49\end{array}$

4.2 Confirmação da identificação dos isolados de Leishmania spp. $\quad 49$

4.3 Padronização do teste de sensibilidade de promastigotas a drogas 53

4.3.1 Medida da turvação

4.3.2 Modificação do teste de MTT 55

4.3.2.1 Teste de MTT e contagem de promastigotas em diferentes condições de cultura $\quad 55$

$\begin{array}{ll}\text { 4.3.2.2 Microteste de MTT } & 57\end{array}$

4.4 Atividade do tamoxifeno e anfotericina B contra promastigotas de Leishmania in vitro através do microteste de MTT modificado 59

4.5 Suscetibilidade de promastigotas de Leishmania ao antimônio in vitro 62

4.6 Infecção de diferentes tipos de macrófagos por L. (V.) braziliensis 65

$\begin{array}{ll}\text { 4.7 Ensaios de citotoxicidade } & 67\end{array}$

4.8 Sensibilidade de amastigotas de Leishmania in vitro a antimônio $\begin{array}{ll}\text { pentavalente } & 68\end{array}$

4.9 Sensibilidade de amastigotas de alguns isolados de $L$. (V.) braziliensis in vitro ao tamoxifeno 70 

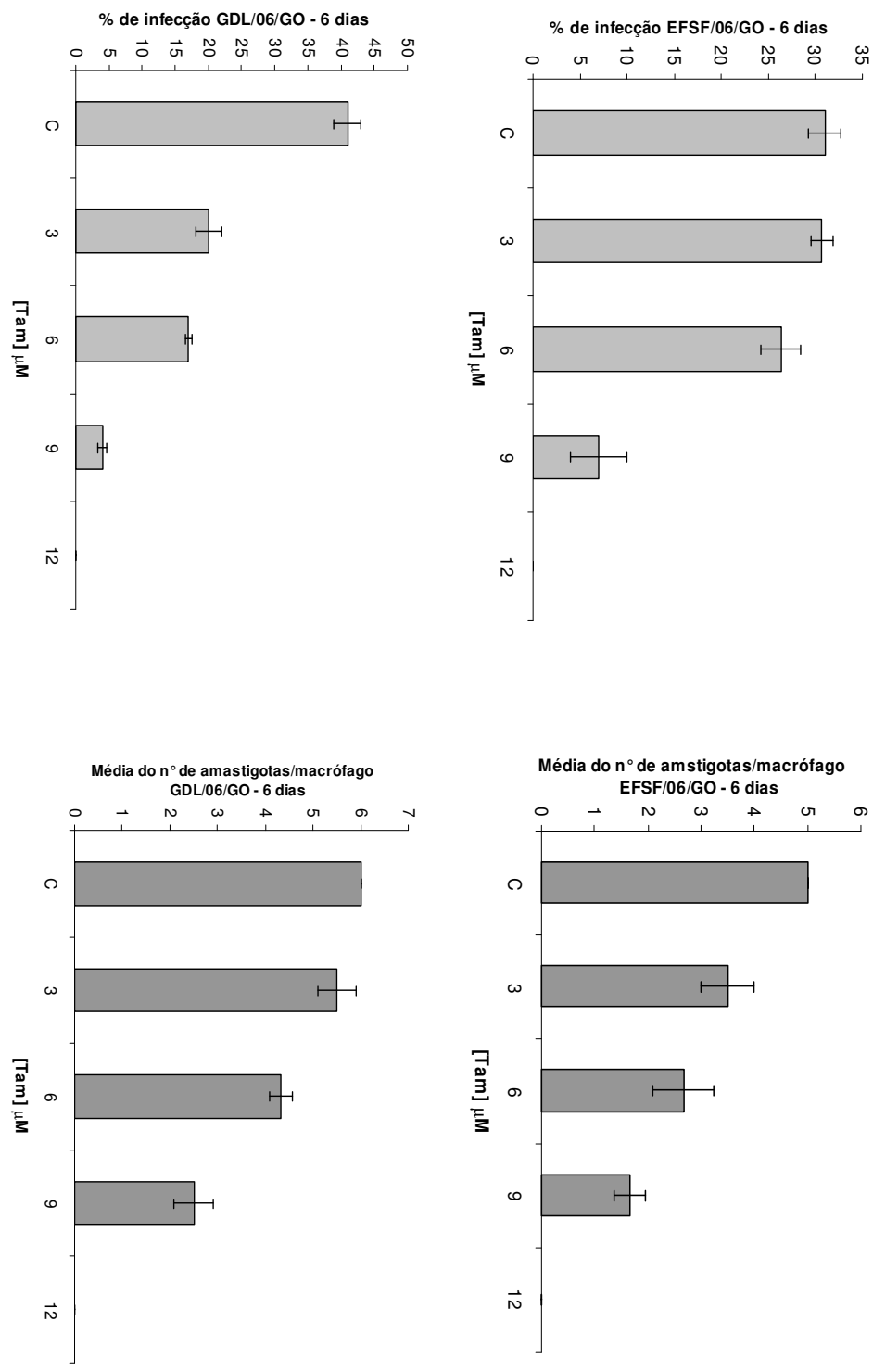


\title{
Tamoxifen as a potential antileishmanial agent: efficacy in the treatment of Leishmania braziliensis and Leishmania chagasi infections
}

\author{
Danilo C. Miguel ${ }^{1 \dagger}$, Rogéria C. Zauli-Nascimento ${ }^{1}$, Jenicer K. U. Yokoyama-Yasunaka ${ }^{1}$, \\ Simone Katz ${ }^{2}$, Clara L. Barbiéri ${ }^{2}$ and Silvia R. B. Uliana ${ }^{1 *}$ \\ ${ }^{I}$ Department of Parasitology, Institute of Biomedical Sciences, Universidade de São Paulo, São Paulo, Brazil; \\ ${ }^{2}$ Department of Microbiology, Immunology and Parasitology, Universidade Federal de São Paulo, Escola Paulista \\ de Medicina, São Paulo, Brazil
}

Received 29 August 2008; returned 3 November 2008; revised 6 November 2008; accepted 23 November 2008

\begin{abstract}
Objectives: The aim of this study was to evaluate the efficacy of tamoxifen in vivo in experimental models of cutaneous (CL) and visceral leishmaniasis (VL) caused by Leishmania braziliensis and Leishmania chagasi, respectively.

Methods: Drug activity was assessed against intracellular amastigotes by treating infected macrophage cultures and evaluating the number of infected cells. In vivo efficacy of tamoxifen was tested in $L$. braziliensis-infected BALB/c mice and in L. chagasi-infected hamsters. Treatment with $20 \mathrm{mg} / \mathrm{kg} / \mathrm{day}$ tamoxifen was administered for 15 days by the intraperitoneal route. Efficacy was evaluated through measurements of lesion size, parasite burden at the lesion site or liver and spleen and survival rate.

Results: Tamoxifen killed $L$. braziliensis and $L$. chagasi intracellular amastigotes with $50 \%$ inhibitory concentrations $\left(\mathrm{IC}_{50}\right)$ of $1.9 \pm 0.2$ and $2.4 \pm 0.3 \mu \mathrm{M}$, respectively. Treatment of $L$. braziliensis-infected mice with tamoxifen resulted in significant reductions in lesion size and $99 \%$ decrease in parasite burden, compared with mock-treated controls. L. chagasi-infected hamsters treated with tamoxifen showed significant reductions in liver parasite load expressed as Leishman-Donovan units and $95 \%$ to $98 \%$ reduction in spleen parasite burden. All animals treated with tamoxifen survived while $100 \%$ of the mock-treated animals had died by 11 weeks after the interruption of treatment.
\end{abstract}

Conclusions: Tamoxifen is effective in the treatment of $\mathrm{CL}$ and $\mathrm{VL}$ in rodent models.

Keywords: chemotherapy, cutaneous leishmaniasis, visceral leishmaniasis, selective oestrogen receptor modulator, SERM

\section{Introduction}

Leishmania braziliensis is the most common causative agent of cutaneous leishmaniasis (CL) and mucocutaneous leishmaniasis in the New World and the main cause for the high annual incidence of the disease in Brazil. ${ }^{1}$ Visceral leishmaniasis (VL), caused by Leishmania chagasi in Latin America, is the most severe form of the disease and may lead to death if untreated. ${ }^{1}$

Leishmaniasis treatment is based on parenteral administration of highly toxic drugs, including pentavalent antimonials, amphotericin B and pentamidine. Resistance to antimonials is widespread in India and oral administration of miltefosine has emerged as an alternative approach, having been approved for management of $\mathrm{VL}^{2}$ Despite current reports validating miltefosine as a satisfactory chemotherapeutic compound in the treatment of L. braziliensis-infected patients in Bolivia, low effectiveness against $L$. braziliensis-infections has been reported in Guatemala. ${ }^{2}$ Therefore, the investigation of alternative leishmanicidal drugs remains imperative.

Tamoxifen, a classical oestrogen receptor antagonist in breast tissue, has been in clinical use for the treatment of breast cancer since $1971 .^{3}$ We have previously shown that tamoxifen is active

*Corresponding author. Tel: +55-11-30917334; Fax: +55-11-30917417; E-mail: srbulian@icb.usp.br

$\dagger$ Both authors contributed equally to this work. 


\section{Miguel et al.}

against several species of Leishmania in vitro. ${ }^{4}$ Recently, we have also demonstrated that treatment of L. amazonensis-infected $\mathrm{BALB} / \mathrm{c}$ mice with tamoxifen results in significant reductions in lesion and ulcer sizes, as well as in a sharp decrease in parasite burden. ${ }^{5}$

In this work, we have focused on the investigation of tamoxifen efficacy in the treatment of leishmaniasis using two distinct rodent models to mimic CL and VL caused by L. braziliensis and L. chagasi, respectively.

\section{Materials and methods}

The strains used were L. (Viannia) braziliensis (MHOM/BR/2001/ BA788) and L. (Leishmania) chagasi (MHOM/BR/1972/LD).

Drug cytotoxicity and activity against intracellular amastigotes were performed as described previously, ${ }^{4}$ except that BALB/c bone marrow-derived macrophages were used. Assays with the reference drug meglumine antimoniate (kindly donated by Sanofi-Aventis) were performed in parallel as described previously. ${ }^{6}$ Experiments were repeated at least three times.

In vivo experiments were approved by the Ethics Committee for Animal Experimentation. Female BALB/c mice $(n=6-8)$ were infected in the left ear with $1 \times 10^{5} \mathrm{~L}$. braziliensis promastigotes as described previously. ${ }^{7}$ Three weeks post-infection, groups were randomized according to the lesion size and $20 \mathrm{mg} / \mathrm{kg} /$ day tamoxifen $(6 \mathrm{mg} / \mathrm{mL}$ tamoxifen citrate solutions in $150 \mathrm{mM} \mathrm{NaCl})$, $20 \mathrm{mg} / \mathrm{kg} /$ day meglumine antimoniate or sterile saline was administered by the intraperitoneal (ip) route for 15 days. Lesion size was recorded as the difference between infected and non-infected ear thickness. Parasite burden was determined 6 weeks after infection using the limiting dilution method. ${ }^{5}$ Body weight was recorded before and after treatment.

Golden hamsters (male or female, $n=6-12$ ) were infected with $1 \times 10^{8}$ L. chagasi amastigotes ip. Four weeks post-infection, animals were treated as described for $\mathrm{BALB} / \mathrm{c}$ mice. At the end of the treatment, parasite burden was determined in the liver as Leishman-Donovan units (LDU) and in the spleen by the limiting dilution assay. ${ }^{5}$ Parasite quantification was obtained for half of the animals in each group. The survival rate of the remaining animals was followed up for 3 months after the interruption of treatment. Serum concentrations of urea and creatinine were determined in hamsters at the end of treatment, using sets of commercial reagents (Doles Reagentes e Equipamentos para Laboratórios, Ltda., Brazil). Each in vivo experiment was repeated independently at least twice.

L. braziliensis and L. chagasi promastigotes differentiated from amastigotes recovered from treated animals were used to test drug sensitivity by determination of tamoxifen $\mathrm{IC}_{50}$ through cleavage of 3-(4,5-dimethylthiazol-2-yl)-2,5-diphenyl tetrazolium bromide (MTT) as previously described. ${ }^{4}$

Statistical analysis was performed using one-way ANOVA followed by Dunnett's post hoc test (GraphPad Prism, CA, USA). A $P$ value of $<0.05$ was considered statistically significant.

\section{Results}

Prior to the determination of tamoxifen activity against intracellular amastigotes, cytotoxicity assays were performed. The $\mathrm{IC}_{50}$ of tamoxifen for bone-marrow macrophages was higher than $20 \mu \mathrm{M}$. The treatment of L. braziliensis- or L. chagasi-infected macrophages with increasing concentrations of tamoxifen for $48 \mathrm{~h}$ allowed the determination of $\mathrm{IC}_{50} \mathrm{~s}$ for intracellular amastigotes (Table 1) and indicated that infection was completely abrogated with $9 \mu \mathrm{M}$ tamoxifen. The reference drug meglumine antimoniate was assayed in parallel with tamoxifen and $\mathrm{IC}_{50}$ values were within the expected range (Table 1).

L. braziliensis-infected $\mathrm{BALB} / \mathrm{c}$ mice were treated with saline, tamoxifen or meglumine antimoniate ip for 15 days. The treatment was initiated 3 weeks post-inoculation allowing the establishment of infection and development of lesions. At the end of the treatment, no statistically significant differences were detected in body weight between groups (tamoxifen, $22.6 \pm 0.7 \mathrm{~g} ;$ meglumine antimoniate, $23.9 \pm 1.6 \mathrm{~g}$; control, $23.3 \pm 2.0 \mathrm{~g})$.

Seven days after the end of treatment, all the animals that received saline showed erythema and swelling at the infection site. A significant decrease in the average lesion size was observed for tamoxifen and meglumine antimoniate-treated mice compared with mock-treated animals (Figure 1a). The average size of lesions at this timepoint was smaller in mice treated with tamoxifen than with meglumine antimoniate but this difference was not statistically significant.

Parasite burden in the lesion was evaluated at 6 weeks after inoculation of parasites (Figure 1b). Significant reductions of 99.0\% and $99.9 \%$ were observed in tamoxifen- and meglumine antimoniate-treated mice, respectively (Figure 1b).

The treatment of L. chagasi-infected golden hamsters was initiated 4 weeks after infection. At the end of treatment, significant decreases in the liver (Figure 2a) and spleen (Figure 2b) parasite burden were detected in hamsters treated with tamoxifen compared with the control group. Tamoxifen was as effective as meglumine antimoniate with a $95 \%$ to $98 \%$ reduction in parasite load.

Table 1. In vitro activity of tamoxifen and meglumine antimoniate against Leishmania intracellular amastigotes

\begin{tabular}{lccccr}
\hline & \multicolumn{2}{c}{ Tamoxifen $(\mu \mathrm{M})^{\mathrm{a}}$} & & \multicolumn{2}{c}{ Meglumine antimoniate $(\mu \mathrm{g} / \mathrm{mL})^{\mathrm{b}}$} \\
\cline { 2 - 3 } \cline { 5 - 6 } & $\mathrm{IC}_{50}(95 \% \mathrm{CI})$ & $\mathrm{IC}_{90}$ & & $\mathrm{IC}_{50}(95 \% \mathrm{CI})$ & $\mathrm{IC}_{90}$ \\
\hline L. $($ V.) braziliensis & $1.9 \pm 0.2(1.7-2.1)$ & 6.0 & & $77.3 \pm 12.1(63.6-87.8)$ & 404.9 \\
L. $($ L. $)$ chagasi & $2.4 \pm 0.3(2.1-2.7)$ & 7.9 & & $259.3 \pm 44.5(214.8-303.8)$ & 1024.7 \\
\hline
\end{tabular}

${ }^{a}$ Values are expressed as means $\pm \mathrm{SD}$; 95\% confidence intervals are shown in parentheses.

${ }^{\mathrm{b}}$ Values are expressed as pentavalent antimony $\left[\mathrm{Sb}^{\mathrm{V}}\right]$. 


\section{Antileishmanial activity of tamoxifen}
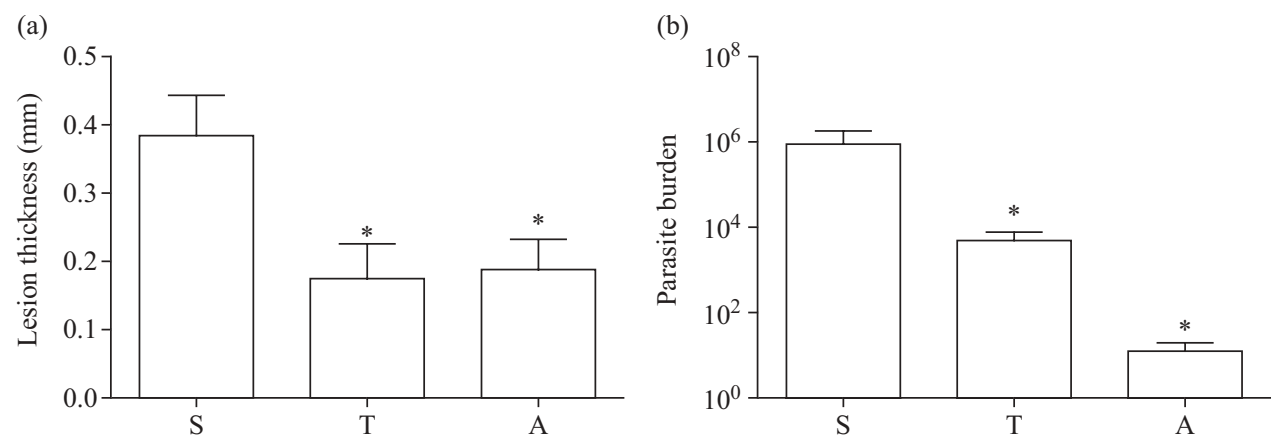

Figure 1. In vivo efficacy of tamoxifen in L. braziliensis infection. Female BALB/c mice were infected with L. braziliensis promastigotes in the left ear. Three weeks after infection, treatment was initiated with saline (S), $20 \mathrm{mg} / \mathrm{kg} / \mathrm{day}$ tamoxifen (T) or meglumine antimoniate (A) ip for 15 days. (a) Lesion thickness recorded 6 weeks after infection $(* P<0.05)$. (b) Parasite burden quantified by limiting dilution 7 days post-treatment $(* P<0.05)$. The results correspond to the mean of three independent experiments, each of them with $n=6$ per group.

(a)

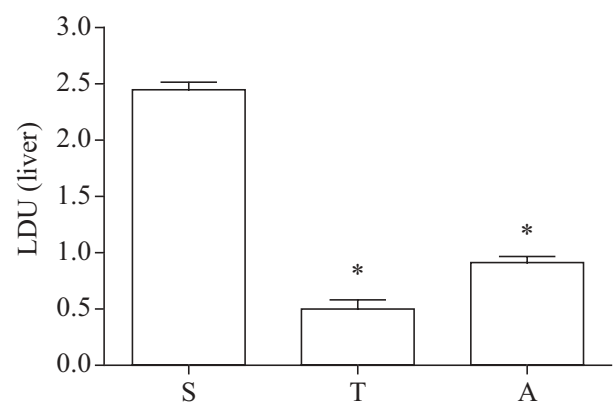

(b)

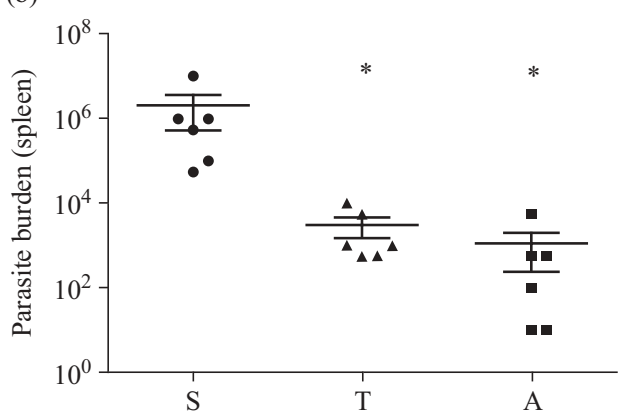

Figure 2. In vivo efficacy of tamoxifen in L. chagasi infection. Golden hamsters were infected with L. chagasi amastigotes. Four weeks post-infection, treatment was initiated with saline (S), $20 \mathrm{mg} / \mathrm{kg} /$ day tamoxifen (T) or meglumine antimoniate (A) ip for 15 days. (a) LDU measured by the number of amastigotes/cell $\times$ liver weight $(\mathrm{mg})(* P<0.0001)$. (b) Parasite burden quantified by limiting dilution at the end of the treatment $(7$ weeks post-infection) $\left({ }^{*} P<0.05\right)$. The results correspond to one of two independent experiments, $n=12$ per group.

To evaluate nephrotoxicity after treatment, serum levels of urea and creatinine were determined. No statistically significant alterations were detected between groups (data not shown). Additionally, at the end of treatment, the average body weight showed no significant variation between untreated $(138.7 \pm 12.4 \mathrm{~g})$, tamoxifen-treated $(127.8 \pm 9.3 \mathrm{~g})$ and meglumine antimoniate-treated animals $(139.4 \pm 15.9 \mathrm{~g})$.

After the interruption of treatment, the survival rate was also assessed. Death in saline-treated animals was detected from week 12 post-infection. By week 18, all control hamsters had died, while a $100 \%$ survival rate was registered in tamoxifen and meglumine antimoniate-treated groups.

Lastly, we investigated whether parasites recovered from tamoxifen-treated mice or hamsters presented reduced sensitivity to the drug. Tamoxifen $\mathrm{IC}_{50}$ values for L. braziliensis and L. chagasi promastigotes recovered from tamoxifen-treated animals were not different from those determined for parasites isolated from control mice $(17.7 \pm 0.4$ and $18.4 \pm 0.7 \mu \mathrm{M}$ for treated and control L. braziliensis and $16.1 \pm 1.9$ and $14.7 \pm 2.9 \mu \mathrm{M}$ for treated and control L. chagasi, respectively).

\section{Discussion}

Tamoxifen, a triphenylethylene derivative, has been shown to be cytotoxic to several neoplastic cell types. ${ }^{8}$ In vitro effects of tamoxifen have also been established for fungal cells ${ }^{9}$ and Leishmania parasites. ${ }^{4}$ Having demonstrated the in vitro activity of tamoxifen against several species of Leishmania, we now show its effectiveness in vitro and in vivo against an L. braziliensis isolate obtained from a Brazilian patient with CL and on a L. chagasi reference strain.

For in vivo efficacy tests, the tamoxifen dose was chosen based on previous reports that established the drug levels in mouse serum after ip administration of $25-100 \mathrm{mg} / \mathrm{kg} /$ day tamoxifen. ${ }^{10}$ The dosage scheme used in the present experiments did not lead to alteration of body weight or other toxic effects.

An ideal experimental model for L. braziliensis infections would be characterized by initial cutaneous lesions followed by spreading to mucocutaneous sites. Unfortunately, such a model is unavailable as yet. BALB/c mice infected in the ear dermis behave as a model of localized CL with erythema and oedema developing at the inoculation site after 3 weeks of infection and evolving to spontaneous healing within 10 weeks of infection. Consequently, to evaluate treatment efficacy, we compared lesion sizes and parasite burden at the lesion peak, 6 weeks after infection. Meglumine antimoniate's effect was more pronounced than tamoxifen's but both drugs significantly reduced the number of parasites at the site of infection. As expected, treatment with meglumine antimoniate did not lead to sterile cure, as observed previously in animal models as well as in humans. ${ }^{11}$ 


\section{Miguel et al.}

We have also established that tamoxifen, when administered to hamsters infected with $L$. chagasi, significantly reduces parasite numbers in both the liver and the spleen. Parasite burden quantified after treatment with tamoxifen was equivalent to that observed in animals receiving meglumine antimoniate. Outstandingly, the percentage of survival was identical between drug-treated groups, whereas saline-treated animals did not survive 18 weeks post-infection. Hamsters infected with L. chagasi develop a progressive disease closely mimicking active human VL. This is, therefore, an appropriate model to test the effect of tamoxifen on L. chagasi infection and confirm its effective leishmanicidal action.

The anti-oestrogen tamoxifen is one of the most prescribed anticancer drugs in the world. Indicated for treatment or prevention of breast cancer, it is used continuously for 5 years with daily doses of $20-40 \mathrm{mg} .{ }^{12}$ Clinical trials have extensively examined the side effects of tamoxifen and the most worrying consequence of prolonged use of this drug is the potential development of endometrial carcinoma. ${ }^{3}$ In this work, tamoxifen was effective as a short-term treatment. We have previously observed that this scheme does not induce changes in uterine weight or histopathology in BALB/c mice ${ }^{5}$ (data not shown).

The efficacy of tamoxifen was the same in male and female hamsters. As the majority of clinical experience with tamoxifen derives from its use in women, concerns could be raised about its toxicity in men. Interestingly, clinical trials have been conducted to determine tamoxifen's usefulness as an antimanic agent. ${ }^{13,14}$ Daily tamoxifen doses of $10-80 \mathrm{mg} /$ day for up to 3 weeks were well tolerated in a controlled test treating 29 patients diagnosed as having bipolar disorder. ${ }^{13}$ Another double-blind placebo-controlled study reported that $20-140 \mathrm{mg} /$ day tamoxifen for 3 weeks did not induce any severe adverse effect in men or women undergoing the treatment. Decreased appetite was the only statistically significant event with increased frequency in the tamoxifen group compared with placebo. ${ }^{14}$ These data indicate that tamoxifen could be safely used in men as well.

The data presented here together with our previously reported findings on tamoxifen's efficacy in L. amazonensis-infected mice ${ }^{5}$ provide the grounds to extend the tests to other models of Leishmania infection. This pioneering alternative may work as a novel chemotherapeutic approach to treat leishmaniasis.

\section{Acknowledgements}

We thank Dr Camila Indiani de Oliveira for her kind donation of the L. braziliensis BA788 strain. We also thank Manoel Aparecido Peres for excellent support in the animal house. We are very grateful to Dr Michel Rabinovitch for invaluable suggestions and support.

\section{Funding}

This work was funded by Fundação de Amparo à Pesquisa do Estado de São Paulo (FAPESP) and Conselho Nacional de
Desenvolvimento Científico e Tecnológico (CNPq). D. C. M. and R. C. Z.-N. were supported by FAPESP and CNPq fellowships, respectively.

\section{Transparency declarations}

None to declare.

\section{References}

1. Bern C, Maguire JH, Alvar J. Complexities of assessing the disease burden attributable to leishmaniasis. PLoS Negl Trop Dis 2008; 2: e313.

2. Murray WH, Berman JD, Davies $\mathrm{CR}$ et al. Advances in leishmaniasis. Lancet 2005; 366: 1561-77.

3. Jordan VC. Tamoxifen: a most unlikely pioneering medicine. Nat Rev Drug Discov 2003; 2: 205-13.

4. Miguel DC, Yokoyama-Yasunaka JK, Andreoli WK et al. Tamoxifen is effective against Leishmania and induces a rapid alkalinization of parasitophorous vacuoles harbouring Leishmania (Leishmania) amazonensis amastigotes. J Antimicrob Chemother 2007; 60: 526-34.

5. Miguel DC, Yokoyama-Yasunaka JK, Uliana SR. Tamoxifen is effective in the treatment of Leishmania amazonensis infections in mice. PLoS Negl Trop Dis 2008; 2: e249.

6. Gebre-Hiwot A, Tadesse G, Croft SL et al. An in vitro model for screening antileishmanial drugs: the human leukaemia monocyte cell line, THP-1. Acta Trop 1992; 51: 237-45.

7. de Moura TR, Novais FO, Oliveira F et al. Toward a novel experimental model of infection to study American cutaneous leishmaniasis caused by Leishmania braziliensis. Infect Immun 2005; 73: 5827-34.

8. Pontiggia $\mathrm{O}$, Rodriguez $\mathrm{V}$, Fabris $\mathrm{V}$ et al. Establishment of an in vitro estrogen-dependent mouse mammary tumor model: a new tool to understand estrogen responsiveness and development of tamoxifen resistance in the context of stromal-epithelial interactions. Breast Cancer Res Treat 2008, in press.

9. Beggs $\mathrm{WH}$. Drug protonation and $\mathrm{pH}$ in relation to the lethal action of tamoxifen on Candida albicans. $J$ Antimicrob Chemother 1996; 37: 841-2.

10. DeGregorio MW, Wilbur BJ, Coronado E et al. Serum tamoxifen concentrations in the athymic nude mouse after three methods of administration. Cancer Chemother Pharmacol 1987; 20: 316-8.

11. Vergel $\mathrm{C}$, Palacios $\mathrm{R}$, Cadena $\mathrm{H}$ et al. Evidence for Leishmania (Viannia) parasites in the skin and blood of patients before and after treatment. J Infect Dis 2006; 194: 503-11.

12. Vogel VG, Costantino JP, Wickerham DL et al. Effects of tamoxifen vs raloxifene on the risk of developing invasive breast cancer and other disease outcomes: the NSABP Study of Tamoxifen and Raloxifene (STAR) P-2 trial. JAMA 2006; 295: 2727-41.

13. Zarate CA Jr, Singh JB, Carlson PJ et al. Efficacy of a protein kinase $C$ inhibitor (tamoxifen) in the treatment of acute mania: a pilot study. Bipolar Disord 2007; 9: 561-70.

14. Yildiz A, Guleryuz S, Ankerst DP et al. Protein kinase C inhibition in the treatment of mania: a double-blind, placebo-controlled trial of tamoxifen. Arch Gen Psychiatry 2008; 65: 255-63. 
Anexo C 

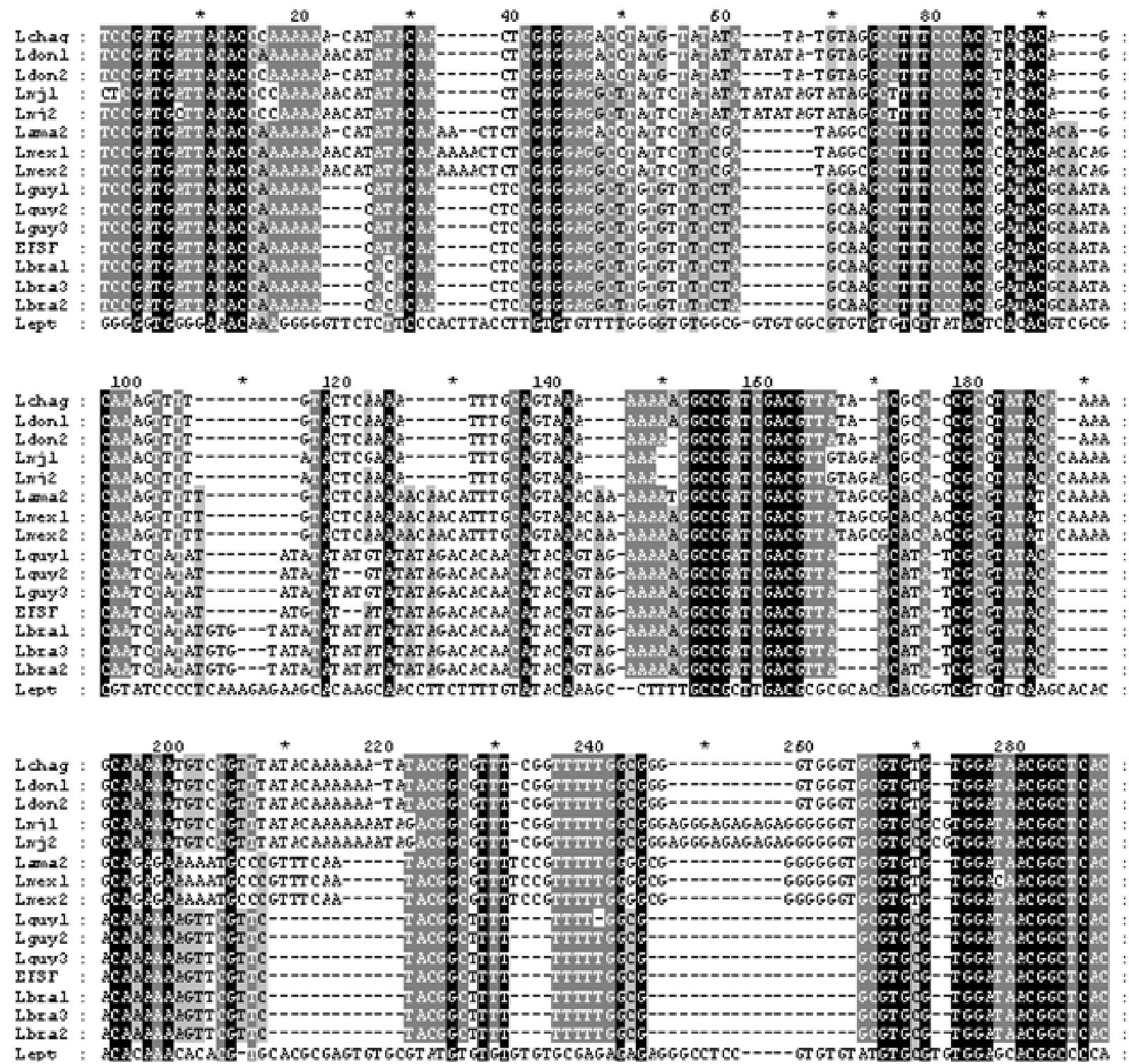


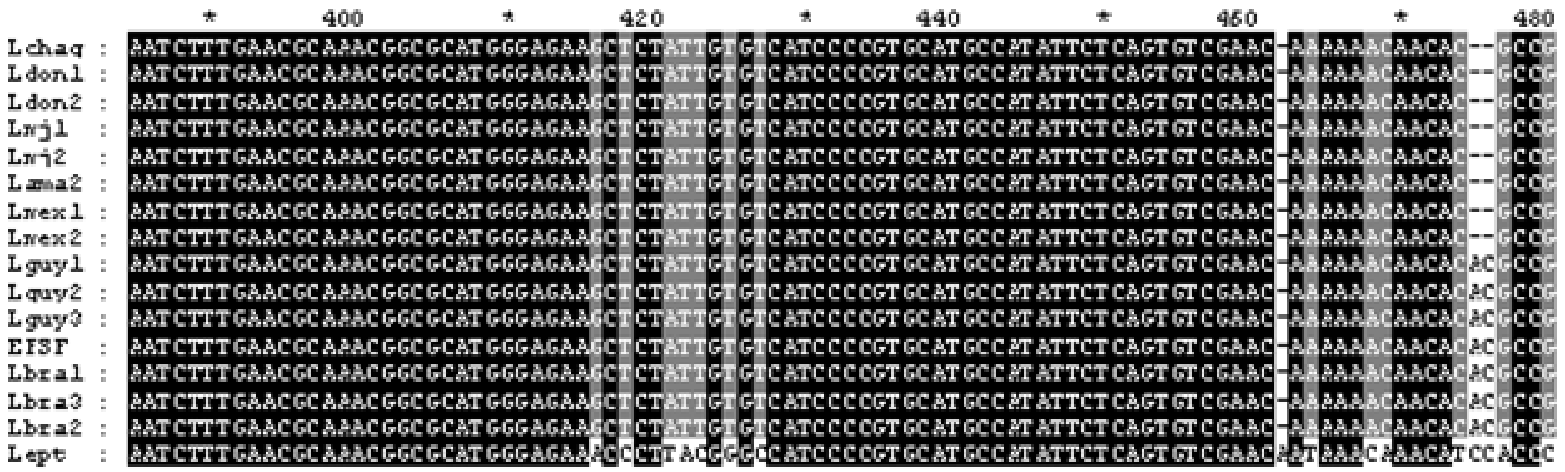

Lehag

Ldor I

Lden?

Lwj 1

แพา?

L $x=2$

Lwex 1

Lwex?

Lay 1

quश

Lbral

Lbra?

Lbea?

$L$ ept

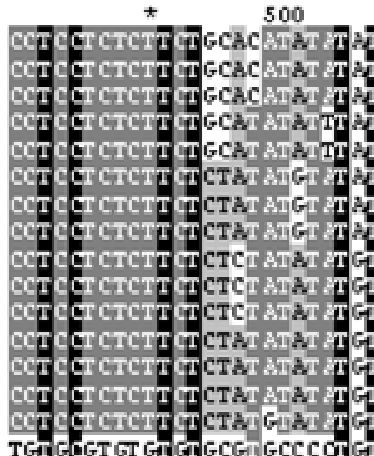

520

540

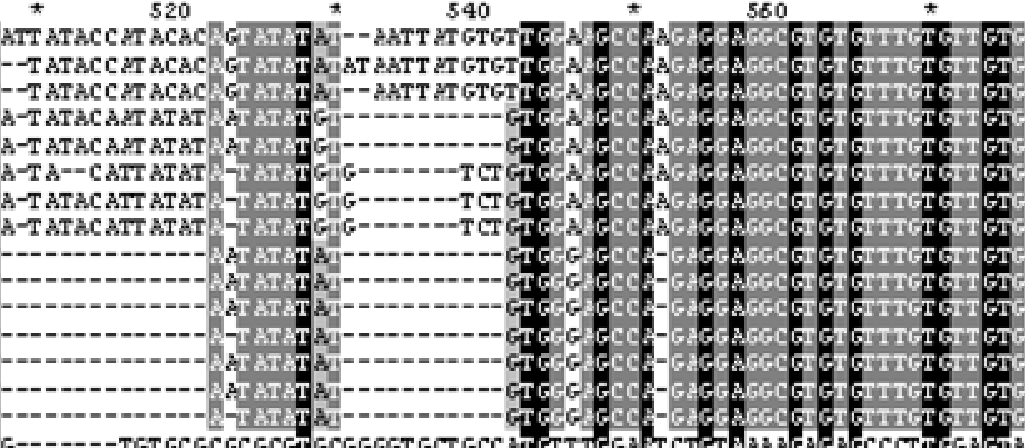

Lehag

Ldon!

Ldon?

Lxi1

Lwj2

Lxine?

Ewer?

Lay 1

Lguy?

Lay?

EIST

Lbral

Lbea?

Lbra?

$L=p t$
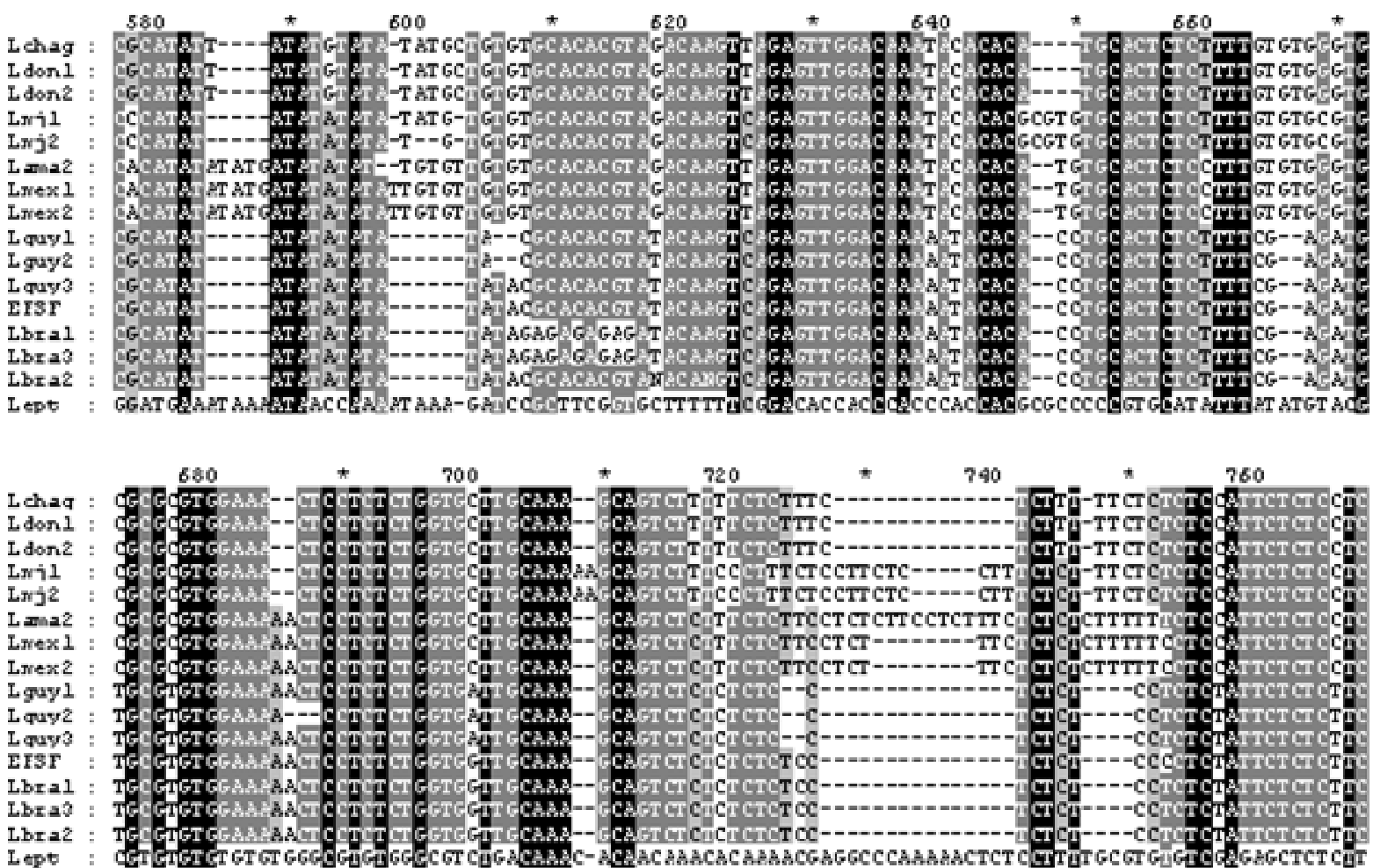


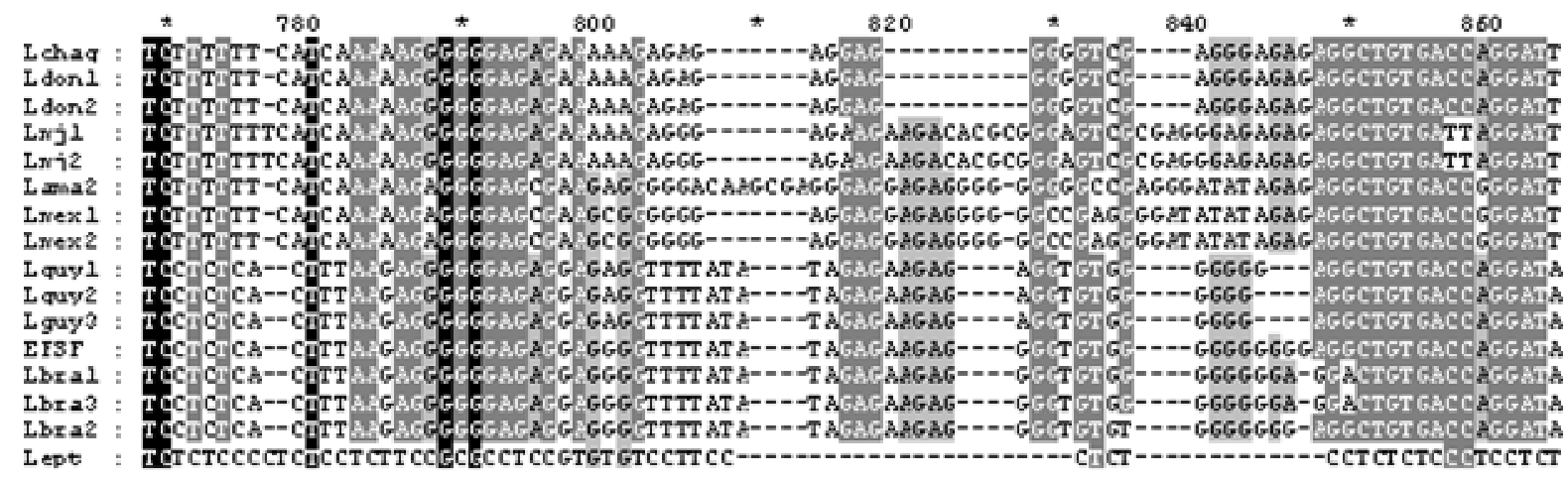

Lehag

Ldonl

Ldon?

Liril

Lwj2

LIITa?

Lwex 1

Linex?

Lay 1

Lguy2

Lay?

EIST

Lbeal

Lbe 23

Lbeat

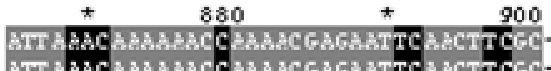

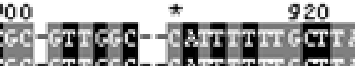

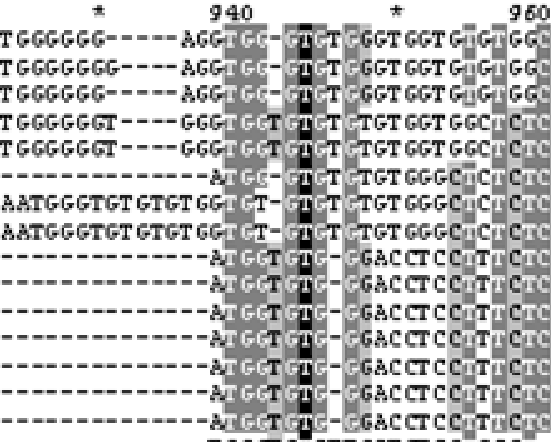
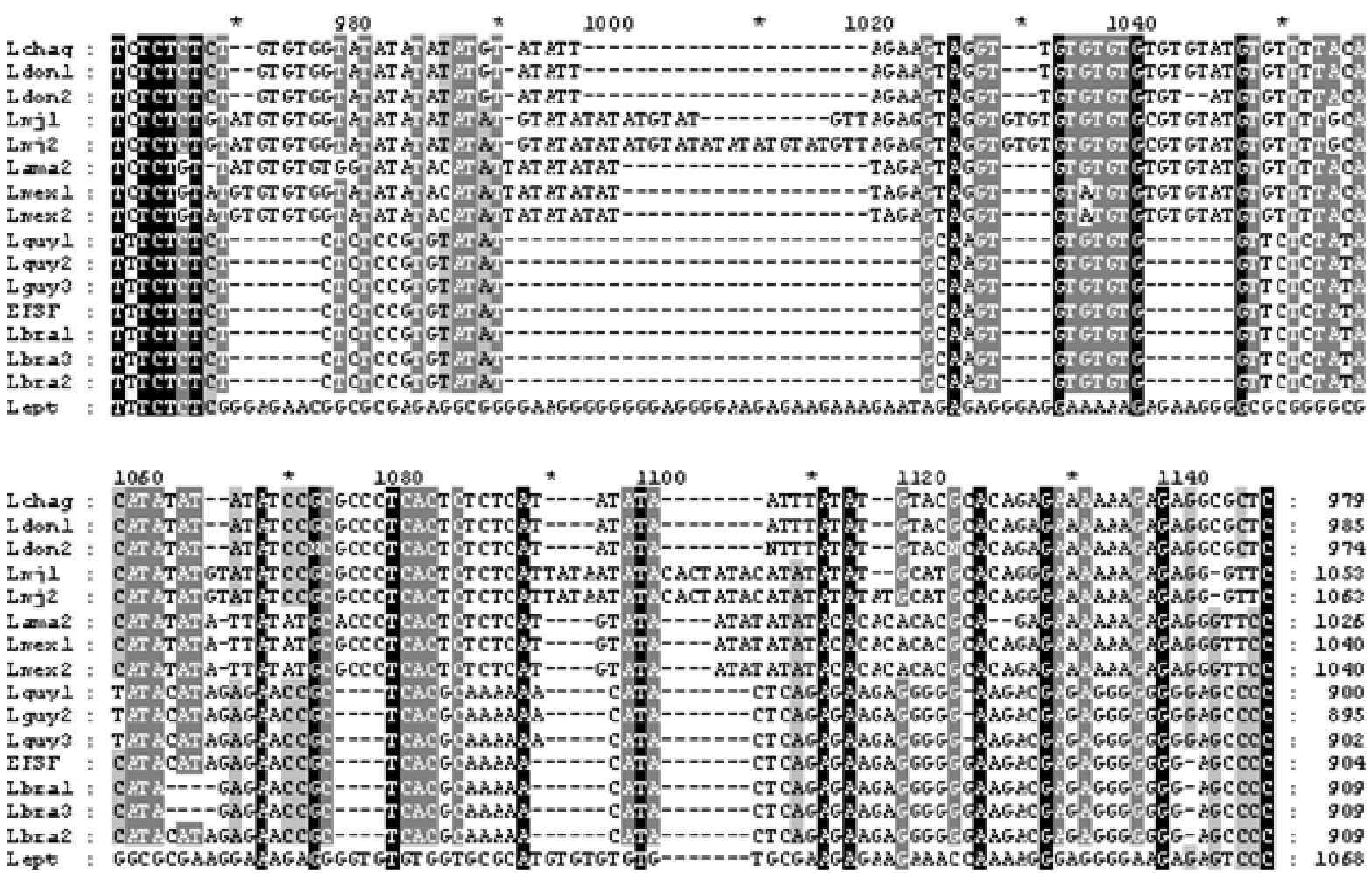